UNIVERSIDADE DE SÃO PAULO

FFCLRP - DEPARTAMENTO DE PSICOLOGIA E EDUCAÇÃO

PROGRAMA DE PÓS-GRADUAÇÃO EM PSICOLOGIA

O cotidiano de uma escola rural ribeirinha na Amazônia:

práticas e saberes na relação escola-comunidade

LIDIA ROCHEDO FERRAZ

Tese apresentada à Faculdade de Filosofia, Ciências e Letras de Ribeirão Preto da Universidade de São Paulo - USP, como parte das exigências para obtenção do título de Doutor em Ciências na área de Psicologia.

Ribeirão Preto - SP 
UNIVERSIDADE DE SÃO PAULO

FFCLRP - DEPARTAMENTO DE PSICOLOGIA E EDUCAÇÃO

PROGRAMA DE PÓS-GRADUAÇÃO EM PSICOLOGIA

\title{
O cotidiano de uma escola rural ribeirinha na Amazônia: práticas e saberes na relação escola-comunidade
}

\author{
LIDIA ROCHEDO FERRAZ
}

Tese apresentada à Faculdade de Filosofia, Ciências e Letras de Ribeirão Preto da Universidade de São Paulo - USP, como parte das exigências para obtenção do título de Doutor em Ciências na área de Psicologia.

Orientador: Prof. Dr. Antônio dos Santos Andrade

Ribeirão Preto - SP 
Autorizo a reprodução e divulgação total ou parcial deste trabalho por qualquer meio convencional ou eletrônico para fins de estudo ou pesquisa, desde que seja citada a fonte.

\section{FICHA CATALOGRÁFICA}

Departamento Técnico Integrado de Bibliotecas da USP

Ferraz, Lidia Rochedo

O cotidiano de uma escola rural ribeirinha na Amazônia: práticas e saberes na relação escola-comunidade. Ribeirão Preto, 2010.

$256 \mathrm{p}$.

Tese de Doutorado apresentada à Faculdade de Filosofia, Ciências e Letras de Ribeirão Preto/USP. Área de concentração: Psicologia.

Orientador: Andrade, Antônio dos Santos.

1. Cotidiano escolar. 2. Escola rural ribeirinha. 3. Análise institucional. 4. Esquizoanálise.

Este trabalho de pesquisa recebeu financiamento parcial da Fundação de Amparo a Pesquisa do Estado do Amazonas - FAPEAM. 


\section{FOLHA DE APROVAÇÃO}

Lídia Rochedo Ferraz

O cotidiano de uma escola rural ribeirinha na Amazônia: práticas e saberes na relação escolacomunidade.

Tese apresentada à Faculdade de Filosofia, Ciências e Letras de Ribeirão Preto da Universidade de São Paulo, para obtenção do título de Doutor em Ciências, na área de concentração em Psicologia.

Aprovado em:

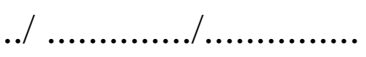

Banca Examinadora

Prof. Dr.

Instituição Assinatura

Prof. Dr.

Instituição Assinatura

Prof. Dr.

Instituição Assinatura

Prof. Dr.

Instituição Assinatura

Prof. Dr.

Instituição Assinatura 


\section{Dedicatória}

A Carlito Ferraz

(11/10/1949-21/12/2009)

A quem não teme desarrumar

Que me desafinou

E continua a desafinar o coro dos contentes

Onde quer que se faça fluir.

Topei dividir o meu/teu sim, o meu/teu não,

Tuas crenças, meus medos.

No momento,

Não há sinal de sol, nem de cais, ou de paz,

E tudo me acalma na lembrança do teu olhar.

Afinal, foi pro que der e vier.

Se o sol sair,

Se a chuva cair,

Por tudo isso, e por ser só isso,

Dedico a você.

No mais, estou indo embora.

Quero ver se há no pomar os cheiros de jasmim,

E se os espíritos brincam no pátio.

$A i$, meu velho vagabundo,

Nada mais urgente que o pó da estrada.

Choro nesse canto A sua ausência,

Seu silêncio

E a distancia que se fez tão grande

E levou você de vez daqui.

Sabe companheiro, algo em mim também morreu,

Desapareceu

Junto com você.

E hoje esse meu peito mutilado

Bate assim descompassado

Que saudade de você!

(Meu silêncio / Cláudio Nucci) 


\section{AGRADECIMENTOS}

\section{Ao Encantamento.}

Ao Prof. Dr. Antônio dos Santos Andrade, por aceitar a orientação deste estudo. Meu profundo respeito e gratidão pela competência, paciência e liberdade em suas orientações. Sabedoria, confiança e serenidade que nos contagia.

A Naruan, meu filho amado, pela compreensão e paciência em minhas ausências. Como um pequeno barco empurrador vai habilidosamente enfrentando as turbulências de rios caudalosos.

À minha mãe, alfabetizadora de minhas primeiras letras e da luta pela vida, e meu pai, alfabetizador de meu gosto pela terra, pelo apoio e incentivo, e por cuidar de meu filho durante os últimos meses de elaboração da tese.

Aos amigos Marilene e Vanderlei, pela presença sempre, cumplicidade e prontidão incansável em estar com o outro, e pelo apoio incondicional na hora mais difícil que se apresentou em minha vida até o momento.

À amiga Ana Cristina, por toda força e por compartilharmos vários momentos desta jornada, nossos medos, tensões, cheiros e paladares.

Às Professoras Doutoras Ana Raquel Lucato Cianflone e Patrícia Rossi Carraro, pelas recomendações no exame de qualificação, fundamentais para o enriquecimento do trabalho.

À Prof ${ }^{a}$. Dr ${ }^{\mathrm{a}}$. Zélia Maria Mendes Biasoli-Alves (In Memoriam), por sua dedicação e ousadia na implantação do DINTER USP-RP/ UFAM.

À comunidade ribeirinha e aos agentes da escola que carinhosamente me receberam e participaram comigo desta empreitada, consentindo minha presença em seu cotidiano, disponibilizando documentos e informações solicitadas.

À Faculdade de Psicologia, coletivo de colegas de trabalho, por me conceder a liberação necessária para a elaboração e conclusão da tese.

Aos colegas da turma de Doutorado, pelos momentos de motivação, alegria e solidariedade.

Às Professoras Doutoras Eucia Beatriz, Rosemeire Carvalho e Cláudia Sampaio, pelo apoio à frente da coordenação do DINTER.

À FAPEAM, pela concessão da bolsa de estudos por oito meses DINTER-RH, e por ter sido um grande estímulo a me fazer não desistir de concluir este trabalho após a morte de meu marido. 
Desarrume o arrumado, viva, Pelo menos uma vez.

(Tempo / Carlito Ferraz) 


\section{RESUMO}

FERRAZ, Lídia R. O cotidiano de uma escola rural ribeirinha na Amazônia: práticas e saberes na relação escola-comunidade. 2010. 256 p. Tese (Doutorado). Faculdade de Filosofia, Ciências e Letras. Universidade de São Paulo. Ribeirão Preto, 2010.

Essa pesquisa teve como alvo a dinâmica cotidiana da vida escolar em uma comunidade rural ribeirinha, localizada no entorno de uma cidade amazônica. Com o acelerado crescimento demográfico das metrópoles e sua intensa e desordenada expansão, comunidades ribeirinhas vem sendo incorporadas ao espaço urbano, com significativas alterações em seu modo de vida e formas de enfrentamento das questões ambientais, econômicas e sociais, que até recentemente não se configuravam no cotidiano destas localidades. O estudo buscou investigar os agenciamentos operados na escola na produção de modos de subjetivação, no contexto destas transformações. Para tal, procurou-se caracterizar a comunidade e o estabelecimento educacional em seus aspectos históricos, políticos e sociais; procurou-se descrever cenas do cotidiano escolar, investigando práticas, e trazendo as avaliações e expectativas sobre a escola e a relação escola-comunidade. A pesquisa, de cunho qualitativo, foi desenvolvida através do estudo de caso etnográfico, adotando como procedimento de investigação a observação participante, a análise documental e a realização de entrevistas. Buscou-se ainda aliar alguns pressupostos que norteiam a pesquisa cartográfica com o campo de estudos com o cotidiano. A leitura dos dados foi feita com base no aporte teórico fornecido principalmente pela análise institucional e esquizoanálise. Para análise do material discursivo utilizou-se o método de análise de conteúdo. O estudo apontou a importância que os moradores atribuem à escola, sendo percebida como componente que favorece a melhoria das condições de vida. Estas concepções são partilhadas com os agentes institucionais, que afirmam a importância da escola enquanto responsável pela socialização e transmissão de conhecimentos acumulados pela humanidade. A escola apresenta-se distante da realidade local, desqualifica o saber tradicional, impondo concepções mercantilizadas e a transmissão de um saber hegemônico, reforçador de uma estrutura de desigualdades. As dificuldades escolares são identificadas como consequência das dificuldades do aluno, de sua família e do ambiente rural. Cabe à escola empreender práticas necessárias à socialização dos alunos e à transmissão de conteúdos e valores necessários à inserção no mercado de trabalho e ao modo de vida citadino. A escola engendra práticas coercitivas, que instituem a diferença como algo qualitativamente inferior, vivenciada como negação. Entretanto, se por um lado é valorizada por representar a possibilidade de ascensão social, por outro, questiona-se a possibilidade de a escola concretizar sonhos e esperanças. Mas algo escapa aos processos de modelização de subjetividades. Há táticas usadas no enfrentamento das estratégias propostas pelo sistema de ensino, que em certos momentos se desprendem da trama dominante e podem movimentar a criação de outros sentidos. A pesquisa intenta contribuir para a compreensão dos atravessamentos presentes nas ações pedagógicas que constituem o cotidiano escolar, potencializando a desnaturalização de práticas instituídas e a produção de novos processos de subjetivação que agenciem o enfrentamento ao projeto histórico de escolarização estabelecido para a educação rural.

Palavras-chave: 1- cotidiano escolar; 2- escola rural ribeirinha; 3- produção de subjetividades; 4- análise institucional; 5- esquizoanálise. 


\begin{abstract}
FERRAZ, Lídia R. The daily life of a rural riverside school in Amazonian: practices and knowledges in school-community relation. 2010. 256p. Tese (Doutorado). Faculdade de Filosofia, Ciências e Letras. Universidade de São Paulo. Ribeirão Preto, 2010.

This research has targeted the daily dynamics of school life in a rural riverside community located in the vicinity of an Amazonian city. With the fast increasing population growth of cities and their intense and disorderly expansion, riverside communities have been incorporated into the urban space, with significant changes in their lifestyle and ways of dealing with environmental, economic and social subjects, which until recently was not incorporated in the everyday of these communities. The study sought to investigate the agencies operated in the school production of subjectivity modes in these transformations' context. To achieve this, we sought to characterize the community and the educational establishment in their historical, political and social aspects, sought to describe scenes of everyday school life, investigating practices, and providing assessments and expectations on the school and school-community partnership. The survey, of qualitative nature, was developed through an ethnographic case study, adopting as research procedure the participant observation, document analysis and interviewing of the subjects. We tried to combine some further assumptions that guide the cartographic research with the field studies with the everyday. The reading of data was based on the theoretical support provided mainly by institutional analysis and schizoanalysis. For analysis of the discursive material it was used the method of content analysis. The study pointed out the importance that residents give to school, being perceived as a component which promotes the improvement of conditions in which they live. These conceptions are shared with institutional agents, whom affirm the importance of school as responsible for socialization and transmission of knowledge accumulated by mankind. The school presents itself away from the local reality, discredits the traditional and popular knowledge, imposing concepts and commoditized transmission of hegemonic knowledge, reinforcing a structure of inequalities. The learning difficulties and disorders are identified as a result of the student's problems, his family's and the rural environment's. It is for the school to undertake the necessary practical socialization of students and the transmission of content and values necessary for integration into the labor market and the way of city life. The school engenders coercive practices, establishing the difference as something qualitatively inferior, experienced as negation. However, if one part is valued because it represents the possibility of social ascent, on the other hand, the possibility of the school to realize hopes and dreams is questioned. But something escapes the modeling processes of subjectivity. There are tactics used in coping with the strategies proposed by the education system, which at times come off the plot dominant and can move the creation of other senses. The research intends to contribute to the understanding of these crossings in the pedagogical actions that constitute the school daily, increasing to unnatural practices and introduced new production processes of subjectivity that agencies confronting the historical project of education provided to rural education.
\end{abstract}

Keywords: scholar daily; riverside rural school; production of subjectivities, institutional analysis; schizoanalysis. 


\section{LISTA DE SIGLAS}

CEB's Comunidades Eclesiais de Base

FUNDEF Fundo Nacional de Desenvolvimento do Ensino Fundamental

IBAMA Instituto Brasileiro do Meio Ambiente e de Recursos Naturais Renováveis

IBGE Instituto Brasileiro de Geografia e Estatística

INPA Instituto Nacional de Pesquisas da Amazônia

MST Movimento dos Trabalhadores Rurais Sem Terra

OSCIP Organização da Sociedade Civil de Interesse Público

PRORED Programa de Redimensionamento da Educação Básica

SME Secretaria Municipal de Educação

UFAM Universidade Federal do Amazonas 


\section{LISTA DE QUADROS}

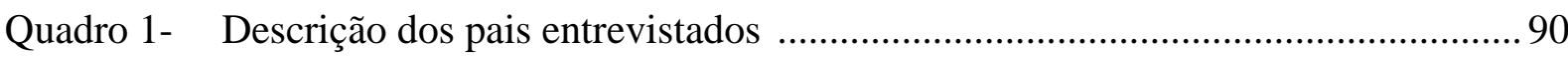

Quadro 2- Descrição da ocupação de salas de aula ........................................................ 115

Quadro 3- Descrição dos funcionários da escola em 2008 ............................................. 123

Quadro 4- Descrição dos docentes e diretora da escola no ano 2008 ............................... 123

Quadro 5- Docentes em Aperfeiçoamento no ano 2008 ................................................ 126

Quadro 6- Rotatividade dos professores nas turmas durante o ano 2008 ......................... 152

Quadro 7- $\quad$ Temas dos subprojetos desenvolvidos no ano 2008 ...................................... 158 


\section{SUMÁRIO}

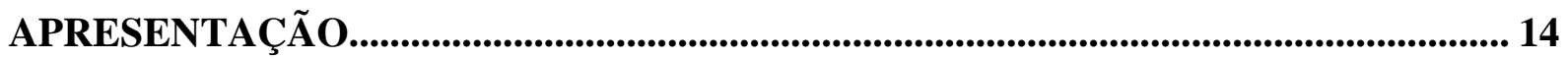

INTRODUÇÃ O........................................................................................................................... 18

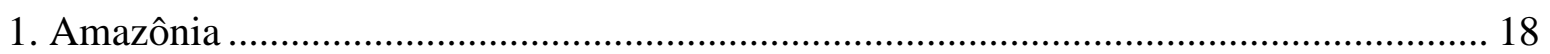

1.1. Povos das águas e da floresta, comunidades ribeirinhas......................................... 22

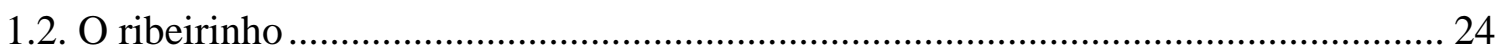

1.3. Imprevisibilidade e movimento .......................................................................... 26

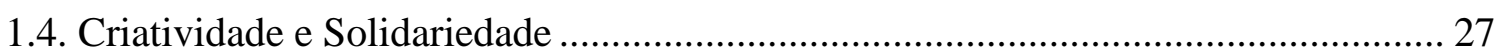

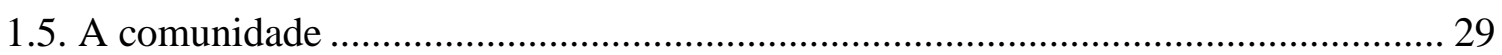

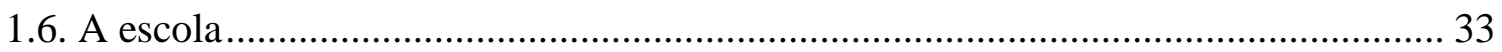

2. Análise institucional, posição e contraposição ……………………………………….... 40

2.1. Algumas ferramentas para transformar e conhecer............................................... 48

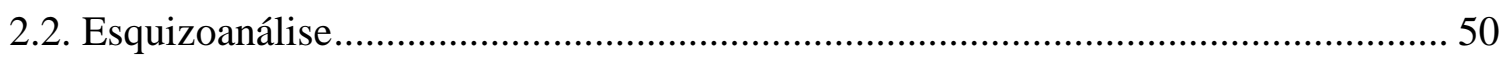

2.3. Desafios à escolarização: por uma escolarização a fios............................................. 58

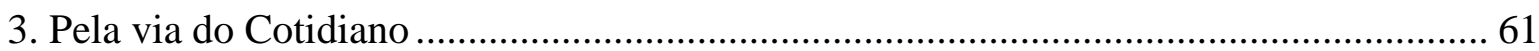

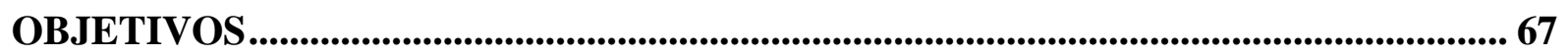

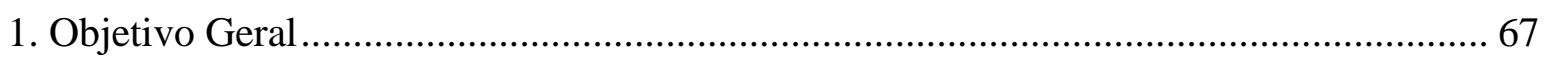

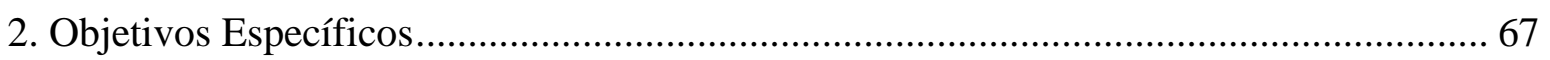

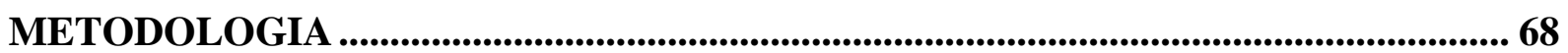

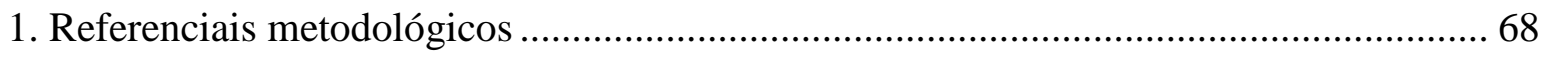

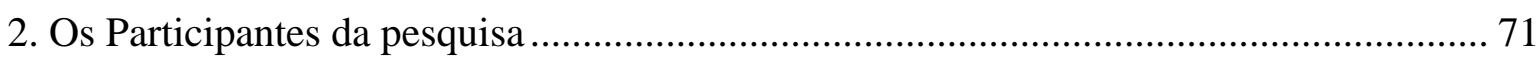

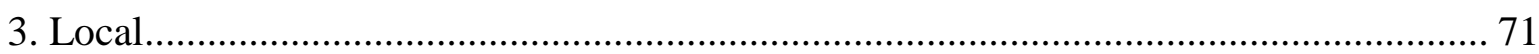

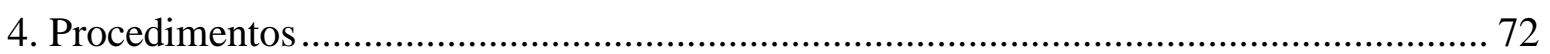

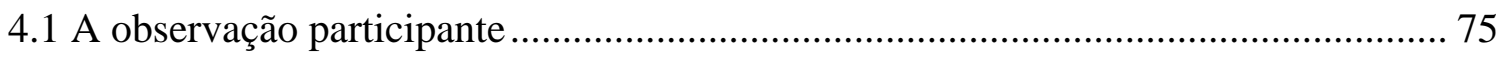

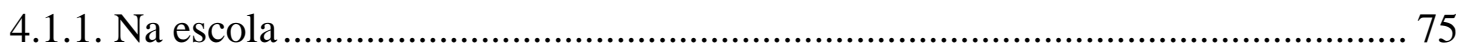

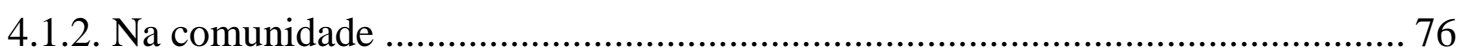

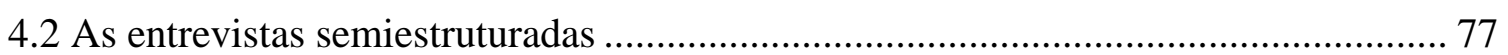

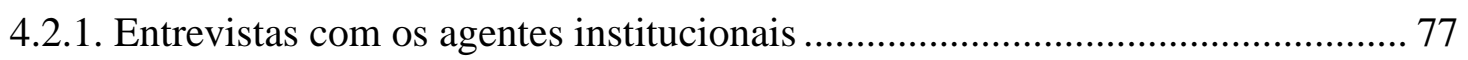

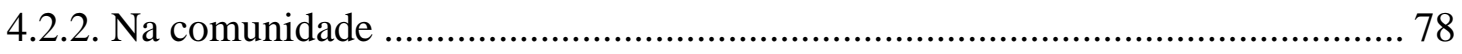

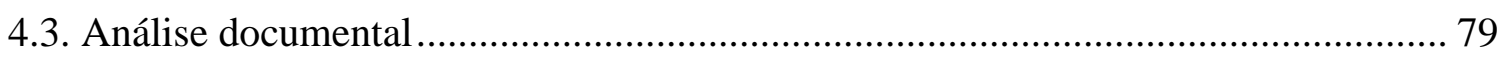

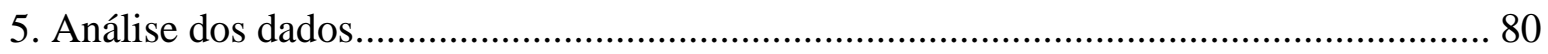

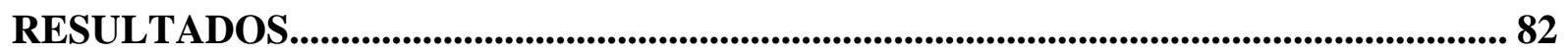

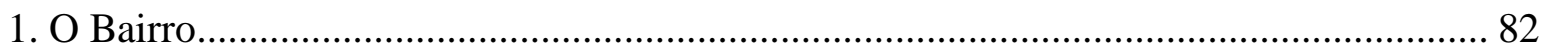




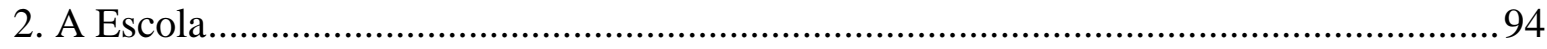

2.1. Histórico, localização e acesso ……………………………………………….....94

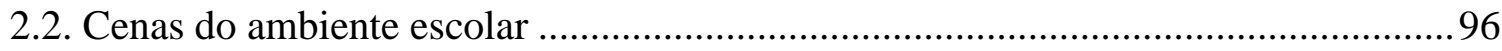

2.3. Os Agentes institucionais ................................................................................ 111

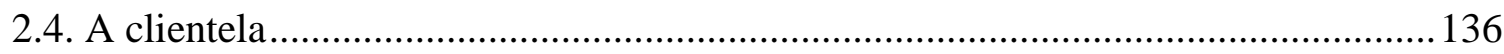

2.5. Distribuição de turmas, turnos e horários............................................................... 140

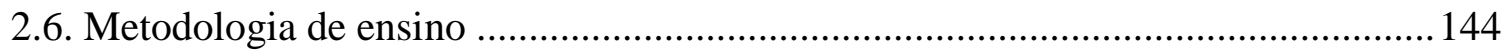

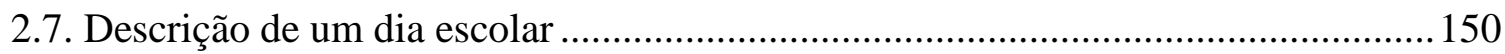

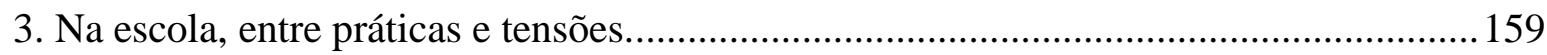

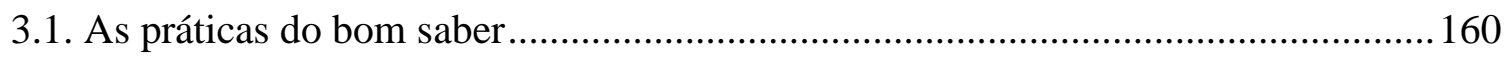

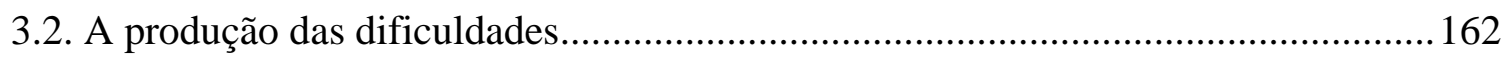

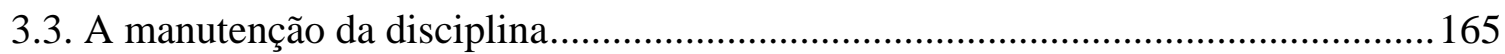

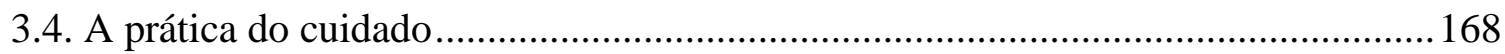

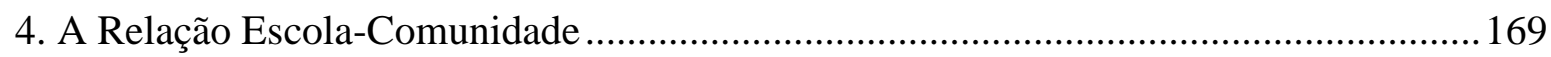

4.1. A importância da escola e do conhecimento escolar .................................................... 169

4.1.1. O que pensam os pais moradores da comunidade sobre a escola......................169

4.1.2. A concepção dos agentes institucionais ........................................................ 173

4.2. Expectativas dos moradores em relação à escola/escolarização ................................176

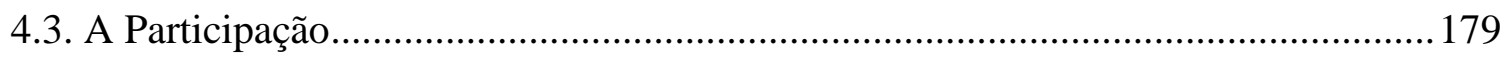

4.3.1. A participação na perspectiva dos pais ........................................................... 181

4.3.2. Os espaços instituídos de participação ……………………………………….... 183

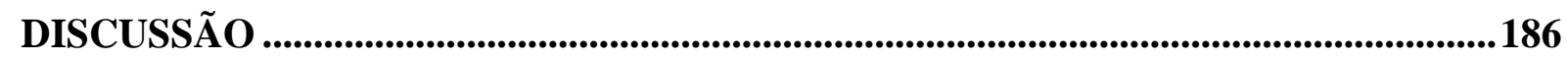

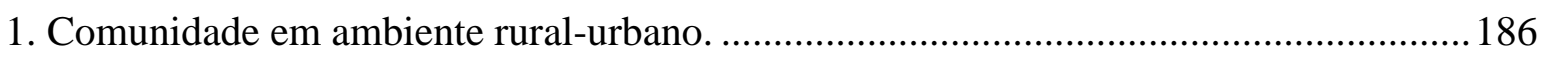

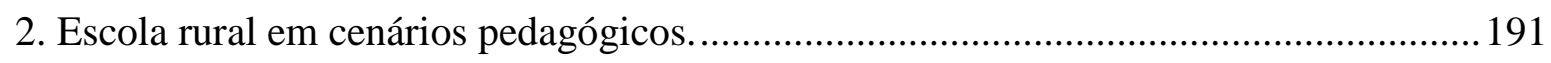

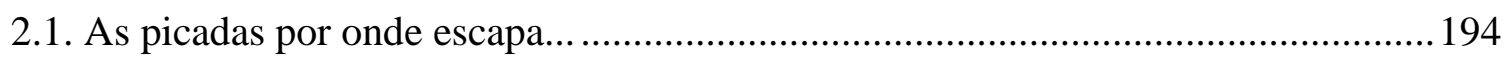

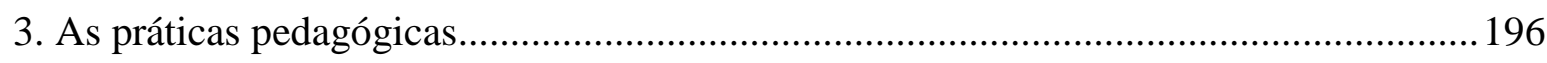

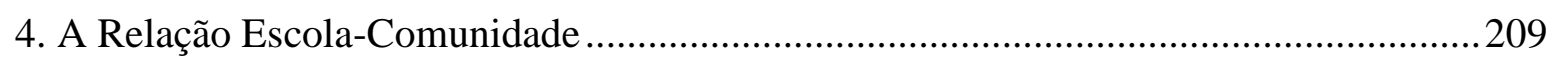

TECENDO CONSIDERAÇÕES .......................................................................................216

REFERÊNCIAS BIBLIOGRÁFICAS ...................................................................222

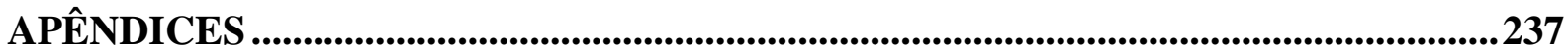

ANEXOS ….............................................................................................Error! Bookmark not defined. 


\section{APRESENTAÇÃO}

Educação é tema que constantemente nos abraça, e estudar foi motivo-destaque desde minha infância, sempre estimulado nas vozes de meus pais. Ser professora era algo tão valorizado, que o desejo fluiu em minha mãe e acabou se concretizando. Em 1984, concluí a formação do magistério de $1^{\mathrm{a}}$ a $4^{\mathrm{a}}$ séries e, em 1985, fui aprovada no concurso para professora da rede municipal de ensino do Rio de Janeiro.

Desde as atividades de estágio no magistério, até aquela época intitulado escola normal, controle de classe e manejo da disciplina eram meu entrave nas avaliações das aulas de didática. Lembro da fala de nossa professora chamando minha atenção para a importância deste item a ser carregado na bagagem do futuro professor. Eu não considerava do mesmo modo, mas não deve ser à toa que as professorandas eram chamadas normalistas. Agradavam-me o Construtivismo piagetiano, as proposições de Paulo Freire objetivando a construção de processos mais dialógicos, e manter disciplina não era meu foco. Gostava do lúdico e de propor desafios aos alunos, pois brincadeira é coisa séria e a gente aprende quando o negócio é sério.

Na graduação, a Psicologia Escolar me oportunizou conhecer a análise institucional. Um encontro fascinante, que me aproximava de novas pistas para repensar os tais modelos educacionais a serem reproduzidos. Lá, também, conheci Maria Helena de Souza Patto, quando apresentava os resultados de sua pesquisa de doutorado. E no mesmo evento me envolvi com os resultados da dissertação de mestrado de Valburga Arns da Silva, cujo título me dizia muito: “cala-boca não morreu”. Entusiamava-me com as misturas e aí me localizei. Trabalhar com escolas passava necessariamente por entender a Educação como prática dialética e dialógica, construída sócio-historicamente pelos sujeitos que criam e recriam o trabalho, na mesma medida em que são por ele criados e recriados. Cabia ainda denunciar práticas e saberes que culpabilizam o aluno por "seu fracasso" e isentam o sistema político da responsabilidade pela produção das desigualdades sociais.

Também durante a graduação tive acesso aos trabalhos de Deleuze e Guattari. Eram momentos de inquietações entre meus professores que começavam a enveredar por conceitos e autores então recentes: Deleuze e Guattari, Lourau e Lapassade, as institucionalidades. Após comentários de um professor, comecei a ler "A lógica do sentido", mas, naquele momento, meus sentidos reificados tinham tanta lógica que o que não fazia sentido era continuar a leitura daquela, para mim, "contra lógica". O fato é que Deleuze doeu e instigou. E eu guardei. 
Eu queria conhecer o Brasil, ou melhor, os tantos Brasis que se fazem neste imenso país. Conheci o Amazonas através de um amazonense que me convenceu a começar esta aventura lá pelo norte. Falava das belezas e encantos de sua "Vila Santa Rita". De frutos e sabores típicos a uma tartaruga do tamanho de uma cama de casal (certo exagero do cantor pescador). Experimentei o lugar e sua gente, acolhedora e um tanto desconfiada. Experimentei os desafios de uma escolarização que pouco dialogava com seus saberes.

O espaço escolar é meu cenário ativador. Assim sendo, voltei a me envolver com escolas, após assumir uma vaga de docente, obtida mediante concurso público, na Faculdade de Educação da Universidade Federal do Amazonas (UFAM). Engajei-me na implantação do processo de interiorização da Universidade e no envolvimento de projetos de extensão, a partir de 1992, quando de minhas idas a comunidades rurais para ministrar cursos de formação de professores. Foi bastante enriquecedor o contato com ambientes ribeirinhos, com alunos, professores e salas multisseriadas, seus desejos e interesse em superar o sentimento de incapacidade de aprender e ensinar, de romper com lógicas excludentes, ainda que ao mesmo tempo tão atravessados por elas.

Os recursos que eu trazia na bagagem não davam conta desta realidade. Eu precisava mergulhar mais. Por isso, decidi fazer o mestrado em "Ciências do Ambiente e Sustentabilidade da Amazônia”. A dissertação abriu frestas, mas à mesma época, a consolidação do curso de Psicologia na UFAM era o engatinhar de um filho que demandava nossa atenção.

Foi com a orientação de estágio em Psicologia Escolar Comunitária que me fiz aproximar novamente desta realidade. Nos anos de contato com uma comunidade ribeirinha, deparei-me com professores inquietos em suas interrogações, mas receosos em partilhar dúvidas e sofrimentos. Por outro lado, reproduzindo modelos importados, relações autoritárias, tornando o ser humano "objeto das instituições". Deparei-me com crianças ricas na alegria de brincar e aprender, mas aparentemente desinteressadas no processo de escolarização formal. Deparei-me com uma escola que parecia não estar atenta à realidade local. Senti crescer o desafio de desmistificar preconceitos em relação aos alunos, de estimular a continuidade dos estudos até o Ensino Superior, e de penetrar em um universo diferente, rico de significados, informações, saberes e demandas que, não apropriados pela escola, são desqualificados pelo saber/poder hegemônico.

Envolvi-me em projetos com crianças de uma comunidade ribeirinha, objetivando "fazer arte", aquela que a mãe diz: "ah menino! Está fazendo arte, não é?". Era esta mesma que nos interessava. Com ela, cultivar o gosto por estudar, e subverter o instituído, 
produzindo diálogos entre práticas psi e os saberes tradicionais, rompendo com práticas discursivas e não discursivas que insistiam em afirmar as dificuldades escolares onde elas não precisavam existir. Chamava atenção o fato de as escolas ribeirinhas estarem à margem das pesquisas em Educação, com poucos interessados nas relações que professores e alunos constroem neste espaço. Chamava atenção a riqueza de possibilidades não exploradas. Procurávamos por respostas para perguntas, e também para falsas perguntas. Paulo Freire dizia que uma pergunta de verdade é aquela para a qual não temos respostas, e muitas de nossas perguntas acabam sendo apenas a confirmação de nossas vaidades.

O doutorado em Psicologia parecia oportuno, mesmo que um pouco dissonante, pois embora simpatizasse com a análise institucional, a Esquizoanálise me soava distante. Mas era um reencontro com autores de minha graduação, e, além disso, gosto de apostas. Entretanto, em função das possibilidades de orientação, acabei apresentando outro projeto, relacionado à família e ao acesso de estudantes ribeirinhos ao Ensino Superior. O curioso é que o falecimento de minha orientadora culminou na redistribuição de seus orientandos, e eu acabei retornando ao projeto e orientador iniciais. Acontecimentos.

Juntamente com o orientador, elegi como foco da pesquisa o cotidiano escolar, procurando investigar práticas ali engendradas, as diferentes relações que ali se efetuam e seus múltiplos atravessamentos.

Na bagagem, minhas verdades. Ainda precisava demonstrar, comprovar que a escola, do modo como se organiza, produz a exclusão e os excluídos, mas também contradições e resistências. Eu queria conhecer para transformar.

O encontro com o prof. Dr. Antônio dos Santos Andrade, o estar no campo e as leituras esquizoanalíticas me fizeram rever vários dos aspectos inicialmente pensados, culminando na constatação de que mais do que buscar respostas para as perguntas, era preciso optar por perguntas que ainda não foram feitas, propor lugares diferentes, e fortalecer o que foi destituído de vida.

Como dizem Alvarez e Passos (2009, p. 131), "conhecer pressupõe implicar-se com o mundo, comprometer-se com a sua produção". Uma pesquisa que se restringe a um conjunto de procedimentos a cumprir pode encontrar apenas o que se espera, o que já está previsto antes de sua enunciação. Os autores que tomam por fundamento os conceitos esquizoanalistas propõem pensar a diferença no que é cotidianamente vivido como homogêneo, repetitivo; investem na singularidade da experiência para investigar seus processos de produção, abrindo-se aos encontros. Isso implica abertura para abarcar as redes de forças que compõem a situação e que favorecem a produção de outras configurações. 
Um exercício micropolítico, e para mim uma provocação: dialogar com um campo teórico desafiador, que me atira num universo conceitual com o qual minha familiaridade é iniciante; leituras que me instigam fascínio e também muitas dificuldades. Um tímido encontro com a Esquizoanálise, certamente promotor e reator de outros encontros.

Ao analisar esta experiência, tenho a clareza de que não darei conta da diversidade que nela se apresenta, nem esgotarei suas possibilidades de compreensão. Optei por mapear determinadas linhas de força fornecedoras, nos limites de tempo estabelecidos para este trabalho, de algumas ferramentas necessárias à discussão de fragmentos do que considero compor o plano de constituição da Educação. Vale ratificar que essa é uma das possibilidades de análise dos múltiplos acontecimentos da vida escolar, e uma entre outras leituras possíveis. Trago, portanto, algumas discussões, a partir de aspectos mais relevantes manifestos na relação entre os fundamentos teóricos e os dados obtidos.

Considerando os propósitos da pesquisa, que culminaram na elaboração desta tese, a mesma foi estruturada a partir da seguinte organização: a introdução abrange uma breve contextualização sobre a Amazônia, contemplando o modo de vida dos povos ribeirinhos e as relações com a escola. $\mathrm{Na}$ sequência da introdução são apresentados aspectos teóricos da análise institucional e da Esquizoanálise. Em seguida, apresentam-se algumas considerações sobre os estudos com o cotidiano escolar, finalizando com os objetivos desta pesquisa.

No segundo capítulo, são apresentados os procedimentos teórico-metodológicos que nortearam a realização da pesquisa, enfatizando os participantes envolvidos e a metodologia utilizada, como referência para obtenção dos dados em seus diversos níveis e desdobramentos.

No terceiro capítulo, constam os resultados da pesquisa, obtidos no período de coleta de dados, através da contextualização do bairro e da escola. Expõem-se, ainda, as concepções e expectativas dos moradores e professores sobre a escola, bem como aspectos relacionados às práticas pedagógicas e à relação escola-comunidade.

No quarto capítulo, constam as discussões relevantes sobre o assunto, realizadas a partir dos registros das observações, complementadas por relatos e explicações fornecidos pelos professores e moradores, nas entrevistas realizadas ao longo da permanência em campo.

Finalmente, mas não encerrando esta caminhada, apresentam-se algumas considerações, procurando apontar implicações educacionais que a pesquisa pode oferecer a este campo de saber. 


\section{INTRODUÇÃO}

\section{Amazônia}

O cenário é mundial e a região amazônica palco das crescentes considerações e preocupações, em virtude dos condicionantes das questões ambientais que, antes despercebidas, vieram à tona com o exagero do modo de produção industrial na sociedade capitalista ${ }^{1}$.

Os discursos da atualidade ressaltam o enorme potencial da região amazônica, seja como celeiro inesgotável de possibilidades de exploração dos recursos naturais, por sua dimensão territorial, como fronteira de expansão, ou como cenário de uma vasta diversidade sociocultural, com populações urbanas, rurais e indígenas de ocupação secular e milenar, constituindo-se como uma região complexa e desafiadora (ADAMS; MURRIETA, 2006; DIEGUES, 2005; BECKER, 2005; AB'SABER, 2005; WITKOSKY, 2007).

Djalma Batista (1976) argumenta que, sob uma auréola de lenda e fascínio, a Amazônia exerce atração e oferece possibilidades de inexplorados domínios para a inteligência. No imaginário, continua encarnando o papel do novo mundo, inóspito, fantástico, mágico, que animou elites europeias e viajantes desde o descobrimento do Brasil, suscitando ideias e concepções controversas, especulações várias e pouca compreensão sobre sua realidade (MEDEIROS, 2004).

Não há quem discorde de que é imperativo modificar o padrão de desenvolvimento que alcançou o auge na década de 1980, e interferir no uso predatório das fabulosas riquezas naturais que a Amazônia contém. São diversos os autores que sustentam que sua preservação deve ir conectada à implantação de estratégias de desenvolvimento sustentável que, respondendo às inevitáveis demandas de crescimento, saibam preservar a idiossincrasia das populações amazônicas e proteger a diversidade da região. Também não se desconhece que as populações tradicionais possuem um secular conhecimento acumulado para lidar com o trópico úmido (ALMEIDA, 2008; HARRIS, 2006; BECKER, 2005; DIEGUES, 2005, 1996; MORÁN, 1990; WAGLEY, 1977) e que esse saber, se utilizado, deve contribuir para o ecoenvolvimento local e mundial.

\footnotetext{
${ }^{1}$ Economia e produção vistas de modo desvinculado e dissociado do meio natural, tendo por base a demasiada transformação dos recursos naturais em bens materiais; excessiva exploração dos ecossistemas naturais, sem considerar os gravames decorrentes desta exploração.
} 
Entretanto, no entrecruzamento de discursos e políticas, e ao sabor desse universo de riqueza e abundância, paira uma Amazônia oprimida por sucessivos planos e projetos que, historicamente, têm tratado populações e espaços de forma homogênea, desconsiderando suas especificidades e multiplicidade. Desde os voltados para ocupar, desenvolver e "integrar a região a qualquer custo" " a certos atuais modelos ditos sustentáveis de uma onda pseudoecológica que invadiu o mundo nos últimos tempos. Conforme Oliveira, M. (2005), a perspectiva de atender as necessidades externas em detrimento das locais sempre fez parte do cenário de desenvolvimento proposto para a Amazônia, com a destruição de habitats e da diversidade biológica, étnica e cultural, levando ao comprometimento das condições de vida das populações humanas locais, sobretudo para os segmentos empobrecidos. Santos (2005), tomando como referência o meio rural, afirma que, historicamente, os recursos da diversidade biológica e os conhecimentos tradicionais a eles associados têm sido apropriados através de estruturas e estratégias que degradam o ambiente e disseminam a exclusão social entre as populações tradicionais. "Transformar a diversidade biológica amazônica em mercadorias à custa da expropriação e exploração das populações tradicionais tem sido, sem dúvida, historicamente, um dos empreendimentos mais promissores da região" (SANTOS, 2005, p. 114). O autor acrescenta que desde os primórdios da colonização europeia a Amazônia esteve subordinada a grupos de interesse que concentram o poder e o controle da produção, e instrumentalizam o poder público na rota das estruturas econômicas que controlam. Uma rede de relações de poder que sustenta uma hierarquia social que viabiliza a exploração econômica das potenciais riquezas naturais e dos trabalhadores ribeirinhos, na sua maioria agricultores, pescadores e extrativistas, mantendo-os na estagnação política e tecnológica, e na dependência de quem detém certo volume de capital e controla o poder público.

A dinâmica de ocupação dos espaços amazônicos está diretamente relacionada aos sucessivos eventos da história socioeconômica da região ${ }^{3}$. Para Oliveira, M. (2005), o fator econômico, tanto na fronteira agrícola como na indústria, foi e continua sendo o elemento

\footnotetext{
${ }^{2}$ A estratégia de ocupar a Amazônia a qualquer preço, foi lastreada por uma série de incentivos fiscais à agropecuária. Desde 1966, quando os incentivos foram criados, mais de quinhentos projetos foram aprovados e poucos foram rentáveis. Não houve incentivos para a produção de látex e coleta da castanha e outros cocos, pois eram consideradas atividades atrasadas, que não ocupam efetivamente o território (DIEGUES, 2005).

3 Desde a colonização vários processos migratórios espontâneos ou dirigidos, produziram a ocupação da Amazônia. Iniciou com o diretório dos índios no séc. XVII, seguido do período pombalino no séc. XVIII, que executou a expulsão dos jesuítas e a chegada dos colonos europeus. Intensificou-se com o ciclo da borracha no séc. XIX e início do séc. XX, e a fase dos grandes projetos do séc. XX (CRUZ, 2007) até o Programa Governamental "Avança Brasil", nos dias atuais.
} 
preponderante causador de enormes mudanças na região norte, quer seja na área econômica ou no cenário político, social e cultural.

O espaço rural revela um panorama de grande complexidade. Tendo como fatores de atração os ciclos do ouro negro, a expansão da "fronteira agrícola" e a disponibilidade de terra barata, quando não gratuita, e como fatores de expulsão de sua área de origem a modernização no campo e a concentração de terras (OLIVEIRA, M., 2005), muitos camponeses, em diferentes momentos históricos, foram conduzidos para a região, estimulados por programas governamentais que, além de não proporcionar infraestrutura necessária à vida neste local, transplantaram modelos agrícolas e de "desenvolvimento" não adequados a um ambiente de floresta tropical-úmida. Além disso, os camponeses precisam lidar com restrições. A terrafloresta-água que presenteia o homem com uma abundante fonte natural de produtos é também aquela que, contraditoriamente, cria as condições mais adversas. Lidar com o ambiente amazônico requer mergulhar em uma materialidade singular. E frágil.

Submersa na exuberância está sua imensa fragilidade. As condições de existência desse manancial de riquezas e potencialidades dependem de uma delicada e peculiar rede de relações, em que a manutenção ou destruição de um subsistema afeta diretamente o sistema geral e, por conseguinte, altera a biodiversidade (FRAXE, 2000). Aqui não há sistema homogêneo, muito menos monoculturas. É a diversidade que faz acontecer a vida, e a maior ameaça a essas condições de existência está representada pelo avanço das atividades mercantis, fruto da pressão de um modelo econômico que tem como base de sustentação a exploração comercial. Cruz (2007) considera que a expansão capitalista gerou transformações nas relações dos ribeirinhos com as diferentes espacialidades que compõem seu modo de vida, a atividade agrícola, florestal e o uso da água. Tais modificações, conforme este autor, decorrem fundamentalmente das políticas implementadas pelo Estado brasileiro para a Amazônia.

Esses processos desencadearam outro fenômeno: a urbanização acelerada, desorganizada e o crescimento populacional das capitais, evidenciados nos últimos censos demográficos segundo as estatísticas do IBGE, num movimento interno que direciona fluxos migratórios para as cidades e, com maior intensidade, para as capitais.

Com a falência da borracha, muitos soldados ${ }^{4}$ refugiaram-se nos arredores das cidades, compondo áreas periféricas; outros se acomodaram às margens de rios e igarapés, encorpando ou constituindo pequenas comunidades ribeirinhas. Assim se formou a comunidade compreendida neste estudo, na primeira década do século XX, ocupada inicialmente por treze

\footnotetext{
${ }^{4}$ Os camponeses trabalhadores nos seringais no segundo ciclo econômico foram denominados soldados da borracha.
} 
famílias ribeirinhas que, descendo a remo pelas calhas dos rios Madeira, Purus e Juruá, encontraram um espaço, nas proximidades de um centro urbano, para se instalar e trazer a família.

O advento dos grandes projetos para a Amazônia, aliado às grandes enchentes/cheias ocorridas à época e à omissão do poder público, provocou nova fase de migrações, tanto do interior dos estados como de outras regiões do país, produzindo uma acelerada e desordenada expansão das capitais. Nas comunidades rurais, não há hospitais, órgãos do poder judiciário e, quando muito, há somente uma escola. Conforme Santos (2005), a conjunção de tais problemas é suficiente para entender o que leva o ribeirinho das comunidades de várzea a mudar-se para as favelas, nas periferias dos centros urbanos. Com isso, estendeu-se a malha urbana até áreas rurais, que há pouco tempo constituíam comunidades ribeirinhas isoladas. Bairros foram criados via ocupações, sem qualquer forma de planejamento por parte dos órgãos governamentais, acentuando a interiorização tanto por terra firme, quanto por margens e igarapés, e comunidades tradicionais passam a configurar periferias das cidades, com a desestruturação das formas de organização e reprodução material e sociocultural e o aparecimento de questões até então ausentes em seu cotidiano.

Mas a Amazônia é uma região que se move. Um movimento intenso da atividade humana, em busca de alguma coisa, sempre. E apesar de pressões cada vez mais intensas, a Amazônia conserva em sua singularidade as principais marcas de seu patrimônio natural, social, cultural.

Este movimento não se faz sem confrontos. A ocupação da Amazônia não foi pacífica, mas resultado de choques e conflitos de terra, opondo povos tradicionais, colonos, e os interesses de "donos" de terras, mineradores, criadores de gado, nacionais e internacionais (DIEGUES, 2005; VELHO, 1976). Em alguns casos, camponeses individuais ou mesmo grupos inteiros foram forçados a deixar a terra que haviam cultivado, sem nenhum tipo de compensação. Almeida (2005) remete-nos a pensar o ecossistema amazônico como produto de relações sociais e de antagonismos, num campo de lutas pelo controle e apropriação das formas de conhecimento, do patrimônio genético, das tecnologias e seu uso, e dos recursos naturais, campo este em que os povos tradicionais também recorrem a estratégias coletivas para sua organização, produzindo sua resistência. A velocidade impressa pela lógica produtivista contraria a lógica ecológica, desafia a natureza, e estes povos reconhecem que a ameaça ao ambiente significa um decreto de morte (DIEGUES, 2005). Becker (2005) situa esta questão indicando que a sociedade civil tem sido um agente fundamental, tanto no campo como nas cidades, especialmente por suas reivindicações de cidadania, que inclusive influem 
no desenvolvimento urbano e no reposicionamento de políticas públicas. A Amazônia é atualmente uma região no sistema espacial nacional, com estrutura produtiva própria e múltiplos projetos de diferentes atores. Alternativas ao desenvolvimento e à produção de conhecimentos acerca dos movimentos desta região devem abranger o reconhecimento do saber tradicional e o envolvimento militante de amazônidas e amazonantes ${ }^{5}$, na consolidação de políticas e práticas para o envolvimento. Cabe gerar ondas que potencializem novos agenciamentos.

\subsection{Povos das águas e da floresta, comunidades ribeirinhas.}

Amazônia não é terra de gado, de soja, de arroz, de cana-de-açúcar, de monoculturas... Jessé Santos

Na Amazônia, a vida gira em torno dos rios. A vida se produz e reproduz dentro e nas margens de rios, lagos e igarapés, onde concentram 90\% dos municípios e comunidades, no seu ritmo e tempo. O homem amazônico constrói seus modos de vida ${ }^{6}$ a partir das intensas e íntimas relações que mantém com os diversos elementos da natureza, basicamente terra, floresta e água, onde se instalou uma presença rural fortemente marcada por povos e comunidades tradicionais.

Concorda-se com Almeida (2006), quando o autor se utiliza da denominação "povos e comunidades tradicionais" ao designar os agrupamentos camponeses, em particular, neste estudo, os ribeirinhos - habitantes das várzeas. Segundo este autor, povos ou comunidades são os termos mais indicados para nomear as sociedades que habitam os interiores amazônicos e que preservam o estilo de vida tradicional. $\mathrm{O}$ autor argumenta que a noção de populações tradicionais utilizada amplamente pelo poder público é segregadora e não comporta a diversidade de povos ou grupos sociais que existem na Amazônia. Chaves (2003) também contribui para esta conceituação, ao salientar que o termo 'população tradicional' representa a denominação geral de uma categoria mais designativa que conceitual, a fim de operacionalizar a identificação dos atores, valorizar papéis e orientar políticas, visto que tal designação destina-se a identificar diversos grupos sociais que apresentam similitudes entre si, mas que são distintos, em função dos diferentes agenciamentos no ambiente em que vivem,

\footnotetext{
${ }^{5}$ Aqueles que, com ou sem motivo, encontraram na Amazônia o seu plano de composições.

${ }^{6}$ Conforme Pereira, Hamida (2006, 23), o modo de vida compreende "os elementos materiais e imateriais da cultura de um povo: os valores, a religiosidade, as formas de trabalho, as relações de compadrio e vizinhança, a organização social, seus mitos, moral e todo seu regime de verdade".
} 
dos sistemas de produção e modos de vida, da proximidade com mercados consumidores, do nível de organização e do grau de intercâmbio que têm com outros grupos sociais.

É interessante observar que no Brasil, há uma grande variedade de modos de vida e culturas diferenciadas, que podem ser considerados "tradicionais", e somente em 2007, pela primeira vez, um Decreto Federal - Decreto $n^{0}$ 6.040/2007 - reconheceu existência formal de todas as chamadas populações tradicionais do Brasil, incluindo faxinenses (que plantam mate e criam porcos), comunidade de "fundo de pasto", geraizeiros (habitantes do sertão), pantaneiros, caiçaras (pescadores do mar), ribeirinhos, seringueiros, castanheiros, quebradeiras de coco de babaçu, ciganos, dentre outras. Conforme o art. $3^{\circ}$ do Decreto supramencionado, povos e comunidades tradicionais,

[...] são grupos culturalmente diferenciados e que se reconhecem como tais, que possuem formas próprias de organização social, que ocupam e usam territórios e recursos naturais como condição para sua reprodução cultural, social, religiosa, ancestral e econômica, utilizando conhecimentos, inovações e práticas geradas e transmitidas pela tradição (BRASIL, 2007).

Para Antonio Carlos Diegues (2005; 1994), um dos pioneiros no estudo sobre comunidades tradicionais no Brasil, elas relacionam-se a um tipo de organização econômica e social, com reduzida acumulação de capital, onde produtores independentes, baseados no uso de recursos naturais renováveis, estão envolvidos em atividades econômicas de pequena escala, como agricultura, pesca, coleta e artesanato, sem ou com pouca utilização da força de trabalho assalariado.

Esses povos e culturas tradicionais não indígenas são, de uma forma geral, considerados camponeses (DIEGUES, 1996; FRAXE, 2004), e abrigam uma diversidade de organizações socioculturais que se distinguem pelos múltiplos saberes e modos de manejo dos recursos naturais e pela identidade social e política das populações rurais (CHAVES, 2003). São caboclos, ribeirinhos, povos das águas e das florestas, e outros tantos grupos, que trazem como especificidade uma história de baixo impacto ambiental e interesses em recuperar o controle sobre o território que exploram (ALMEIDA, 2008). Por décadas, séculos ou mesmo milênios, desenvolveram e ainda mantêm processos de adaptação a ambientes muito particulares, utilizando uma tecnologia simples, mas eficiente, e praticando uma cultura mítico-religiosa igualmente fundamentada no meio em que vivem. 


\subsection{O ribeirinho}

E saíu o ribeirinho: mestiço imigrado, saído do melting-pot nordestino, entre o branco, o negro, o mulato, o índio, o zambo-cafuz e o curiboca.

Djalma Batista

Utiliza-se o termo ribeirinho para designar os camponeses que vivem à margem das águas e que vivem da extração e manejo dos recursos florestais-aquáticos, e da agricultura em pequena escala. Há algumas variações entre os autores que estudam a Amazônia com base no conceito de camponês, mas que convergem para esta denominação e para a íntima relação com a água:

Cruz (2007), em um estudo sobre a territorialização camponesa na várzea da Amazônia, denomina esta população de "camponês-ribeirinho";

Coelho (2007) refere-se a "ribeirinhos urbanos" no estudo que fez sobre uma comunidade localizada nas proximidades de um centro urbano, ressaltando a presença ribeirinha em áreas urbanas;

Witkosky (2007) realizando estudos sobre formas de uso dos recursos naturais, denomina como "camponeses amazônicos" os que operam nas terras, florestas e águas de trabalho;

Fraxe (2004) utiliza o termo camponês, mas refere-se metaforicamente a esta população como "homens anfíbios", indicando no modo de vida a coexistência em dois ambientes, a terra e a água;

Oliveira Jr. (1991) utiliza o termo "ribeirinhos" para moradores da várzea e "roceiros" para moradores da terra firme.

O ribeirinho é o caboclo que habita a proximidade dos rios, lagos e paranás, com profunda relação com a água, que é o elemento definidor de sua vida (JESUS, 2000). Evolveu como população dominante nos últimos duzentos e cinquenta anos, resultado do encontro étnico e cultural de descendentes indígenas, camponeses nordestinos, africanos e europeus. Do convívio e adaptações ao ambiente, produziu-se o desenvolvimento de padrões culturais característicos, com predominância do legado indígena (cultura cabocla). Destaque-se que este convívio não se deu sem confrontos, oscilando entre formas de resistência e tentativas de integração, e com o ressurgimento de técnicas e afirmação de sua cultura nos períodos de “estagnação" (HARRIS, 2006).

Os ribeirinhos são parte fundamental desta população, pelo conhecimento que detêm de seu ambiente e pela habilidade que possuem para construir seus equipamentos materiais, 
com os quais se apropriam e manejam os recursos que a natureza proporciona. Caracterizamse pelo modo de vida centrado na tradição oral de transmissão do conhecimento, pela vida em comunidade, pela importância dada às atividades de subsistência, em detrimento da acumulação de capital, pela mão-de-obra quase exclusivamente familiar na produção das diversas atividades econômicas, e por uma significativa divisão social do trabalho. Mais do que residir em um território anfíbio, ser ribeirinho é estar em sintonia com a terra-florestaágua (FRAXE, 2004). É sobre o leito dos rios que circula a vida. Em canoas ou motores, buscam o alimento, comercializam seus produtos, vão para a escola, a missa ou o culto, a festa e o enterro. A água é um complemento da vida, ou, como diz Oliveira, J. (2003), "o rio não comanda a vida; ele é parte da vida do homem", pois é espaço de relações sociais, de reprodução econômica e abrigo dos mitos e entidades protetoras.

Ser ribeirinho também comporta uma imagem de inferioridade, uma conotação depreciativa que se refere a uma cultura inferior, e ao rótulo de preguiçoso, rude e indolente. Conforme Medeiros (2004), essa criação, cristalizada no imaginário popular, ainda constitui o pano de fundo para representações da Amazônia, resultando daí uma imagem mitificada, estereotipada, especialmente sobre o homem amazônico; e, a despeito da riqueza e variedade de sua cultura secular, a ideia de inferioridade do homem americano provavelmente influenciou a autoimagem de seus descendentes.

Para Freitas (2005), o ribeirinho é um povo que está mudando de perfil, e está permanentemente em construção. Conforme esta autora, as populações ribeirinhas foram secularmente remanejadas, numa sucessão ininterrupta de gerações ao longo dos quinhentos anos e dos diversos ciclos de ocupação, em várias frentes migratórias, que são também espontâneas e não apenas dirigidas. Considera, portanto, que estas populações em busca da terra e recursos para sobreviver podem ser consideradas ribeirinhas.

Adams e Murrieta (2006) também consideram o caboclo em processo de formação, tendo em vista que os sistemas sociais na Amazônia vêm sofrendo significativas transformações nos últimos trinta anos, e reconhecer a significância destas comunidades implica considerá-las no contexto de mudanças históricas e sujeitas ao mesmo movimento que incorporou outras 'periferias', no âmbito dos sistemas político-econômicos capitalistas.

Na expressão de Witkosky (2007, p. 94), ser caboclo "é ser também uma multiplicidade de seres, é um devir que sempre incorpora novas significações". 


\subsection{Imprevisibilidade e movimento}

Um movimento que segue como rio, ora brando, ora caudaloso; gelatinoso na superfície, intenso no profundo. Manoel Cruz

A vida na várzea é movida pela pulsação das águas, que sobem e descem, inundam e secam, chegando a ter variações de nível superior a 10 metros. As várzeas são ecossistemas de grande biodiversidade, com características próprias, riqueza abundante, e, a despeito da fragilidade natural que lhes é peculiar, têm lugar central na economia e na cultura regional, pois os solos são anualmente rejuvenescidos por sedimentos que são transportados pelo rio e depositados durante a cheia, formando uma camada fértil de solo.

Os moradores da várzea deparam-se anualmente com este movimento: enchentecheia/vazante-seca, e necessitam adaptar suas estratégias de sobrevivência para lidar com as mudanças, nesta alternância. Não há como prever a alteração do nível das águas, não há uma margem exata de volume de água (cheia) e nem de enxugamento (vazante). Há previsões, muitas vezes acertadas, mas pode haver surpresas.

Este ciclo regula, em grande parte, o cotidiano de comunidades ribeirinhas, de tal modo que o mundo do trabalho, os festejos, o calendário escolar e o corriqueiro são organizados em função desta sazonalidade. De fato, a enchente dos rios compromete a realização de várias atividades, como o cultivo da agricultura para subsistência, a caça e a pesca. Durante a vazante-seca, os caminhos são alongados, o acesso prejudicado, dificultando ir à escola ou escoar a produção.

No meio rural amazônico, o tempo é diferente dos contextos modernizados das cidades. E na várzea, é o regime do clima e dos rios que determina o ritmo e o tipo das atividades sociais e produtivas. A noção de distância fluvial não corresponde simplesmente à noção física entre dois ou mais pontos: está relacionada à relação entre o tempo, a oscilação cheia/vazante, e ao meio de transporte utilizado no deslocamento ${ }^{7}$. Comumente, se ouve dizer: "são tantos dias para se chegar a tal lugar”, ou "daqui ate lá, com o motor de 40, dá umas três horas".

$\mathrm{O}$ acesso fluvial também se modifica constantemente. A própria dinâmica das águas e terras encobertas forma verdadeiros mosaicos. Na cheia, os furos ficam abertos, os paranás dão passagem e os lagos transbordam, facilitando o caminho. Já na seca, esse mundo de água quase desaparece e os caminhos fluviais são consideravelmente alongados, surgindo bancos

\footnotetext{
${ }^{7}$ Embarcação regional, canoa com motor de rabeta ou lancha rápida com motor de popa, denominado voadeira.
} 
de areia e praias fluviais que modificam os canais e não raramente tornam-se inacessíveis a embarcações de porte médio. Faz-se imprescindível conhecer por onde passa o canal principal do rio ou lago, para não ficar preso em algum toco de árvore ou banco de areia. Há ainda formação de praias e desbarrancamento das margens, que forçam a mobilidade das comunidades. Limitados pela força da natureza e pelo capital, tornam-se nômades em seu próprio espaço.

A mobilidade contamina tudo: florestas e os indivíduos, os animais e as habitações, os líquidos e os sólidos. Os vegetais são vagabundos, os povos nômades, os peixes incertos, as casas instáveis, as pedras errantes, as águas fugitivas. Praias e canais se deslocam, como se um arrepio sísmico quase imperceptível agitasse aí a crosta terrestre (MORAES, 1936, p.22).

Diante das imprevisões do nível de elevação das águas, que em certos anos provocam as grandes cheias e grandes secas, os ribeirinhos permanecem atentos e sob grande expectativa durante os meses da enchente. Os perigos e dificuldades são enfrentados na medida em que se apresentam, e de acordo com o que se dispõe no momento, para este enfrentamento. É difícil planejar, mesmo sabendo que a cheia vem todos os anos.

Trata-se, ainda, de regiões marcadas por profundas fragilidades sociais, agravadas pela falta de segurança na posse desse território, imprescindível para a subsistência das comunidades e para a preservação do ambiente e da cultura local (ALMEIDA, 2005).

O que vale ressaltar é a capacidade criativa e as estratégias desenvolvidas para a produção da vida neste convívio.

\subsection{Criatividade e Solidariedade}

Trabalho, escola, lazer, economia, mudanças, plantio, extração, saúde, religião, pesca, caça e outros fazeres, estão condicionados às oscilações da possibilidade de utilização dos recursos e sujeitos a um diferenciado calendário. Assim, os ribeirinhos produzem a vida no entrelaçamento e no exercício de múltiplas atividades, de modo simultâneo ou sequencial, e nenhuma de modo exclusivo (FRAXE, 2000). São agricultores e extratores de produtos da floresta, de plantas medicinais, caça ou pesca, combinando o uso de diferentes recursos com o trabalho assalariado e a aposentadoria ou outros benefícios. O plantio de produtos de ciclos curtos é realizado na vazante, a pesca na seca, colheita agrícola na enchente e extração de madeira na cheia. A pesca pode ser considerada uma atividade principal, mas não há padrão homogêneo e a importância de cada atividade varia amplamente, conforme o acesso aos 
recursos, à estrutura familiar e à organização política local. Na cheia, os que moram em casas às margens do rio são impulsionados a mudar de moradia ou construir assoalhos mais altos para escapar dos efeitos da natureza. Na seca, a água fica mais distante e, com isto, o acesso a determinadas localidades e ao escoamento da produção torna-se mais difícil, prejudicando a economia, dificultando a ida à escola.

Os ribeirinhos suportaram com sucesso tanto condições ambientais severas, quanto condições históricas desfavoráveis. Desenvolveram profundo conhecimento sobre o uso desses recursos e dos ciclos biológicos, que se reflete em diferentes estratégias de uso dos recursos locais (DIEGUES, 1996). São práticas adaptadas a ecossistemas específicos na produção de alimentos e uma variedade de outros produtos como materiais para pesca, para construção, fibras, resinas, e plantas medicinais. Criaram formas de adaptação para as casas, para as roças, para colocar os animais e para as rotinas do cotidiano. Como salienta Almeida (2005), não se trata apenas de um repertório listado de plantas ou utensílios, mas controlam os saberes que orientam as relações com os recursos naturais. Tais práticas envolvem o conhecimento sobre como uma determinada erva é coletada e tratada, as fórmulas sofisticadas, o receituário e os respectivos procedimentos de transformação em processo de fusão. $\mathrm{O}$ autor acrescenta que o saber nativo envolve experiências concretas de cooperação no manejo, processamento e transformação de matérias primas, experiências sempre consideradas 'artesanais, pré-industriais ou limitadas', e não obstante sua eficácia, até então não tiveram condições históricas de se estabelecer. Esses sistemas de manejo demonstram a existência de um complexo de conhecimentos adquiridos pela tradição herdada dos mais velhos, de mitos e símbolos que corroboram com a manutenção e uso sustentado dos recursos naturais.

Tendo na família a base das relações sociais, culturais, políticas e econômicas, as comunidades ribeirinhas compartilham a mesma territorialidade, costumes e valores. Os problemas enfrentados são solucionados com base em um forte nível de solidariedade entre os vizinhos, em geral unidos por laços de parentesco e compadrio. Estes laços, fortalecidos através das tradições católicas, articulam não apenas relações espirituais, mas também de respeito e apoio material. No universo do trabalho, as estratégias de ajuda mútua são recorrentes, sobretudo, a cooperação, o puxirum $^{8}$ e o ajuri ${ }^{9}$. Em geral, todos os membros da família estão envolvidos no processo do trabalho, que se inicia em idade precoce e, muitas

\footnotetext{
${ }^{8}$ Sinônimo de mutirão.

9 Conforme Chaves (2004), a prática do mutirão qualifica-se como serviço para a coletividade, o trabalho compartilhado para usufruto de todos os membros da comunidade. Pratica-se o mutirão em áreas de domínio da coletividade - escola, centro social. No ajuri, o trabalho realizado de maneira coletiva tem seus resultados partilhados. Destina-se a contemplar as necessidades do grupo, cuja divisão se faz de acordo com as necessidades dos grupos domésticos.
} 
vezes, provoca o afastamento das crianças das escolas, para auxiliar os pais. O trabalho visa, prioritariamente, à produção e/ou extração de víveres para a satisfação das necessidades orgânicas familiares, não se preocupando com a produção do excedente, que é oferecido a terceiros em sistemas de trocas e/ou comercialização. As atividades são mediadas por significativa divisão social do trabalho e os equipamentos são compartilhados com vizinhos e parentes. Essas relações possibilitaram o controle contínuo do acesso aos recursos próximos e sua reprodução social ao longo de várias gerações, garantindo este equilíbrio pela vida em comunidade.

Também há criatividade na resistência. Conforme Jesus (2000), o trabalho sempre foi visto sob a ótica da satisfação de suas necessidades, e não como exploração de suas energias. Essa concepção temporal, espacial, vivenciada pelos caboclos, é confundida com passividade, mas, para o autor, refere-se a um estilo que confunde o estilo padronizado da sociedade capitalista e, ao mesmo tempo, surpreende pela criatividade e profundeza de suas ações.

Há certa reação nativista contra elementos estranhos, numa atitude de inconformação, que é considerada como um dado subjacente de sua cultura. Na opinião de Harris (2006), uma identidade de oposição. Por viver numa lógica de curto prazo e longe dos centros de poder, o caboclo combina a oposição e a indiferença em sua relação com os patrões, tentando evitar, ou pelo menos diminuir a dominação, através de uma vida social aparentemente anárquica.

Márcio Souza assim esclarece:

A população amazonense encontrou um estilo próprio para resistir, uma maneira de enfrentar a voracidade de tantos projetos e até mesmo de sobreviver às elites regionais [...] É uma leseira amazonense, identificada também como uma resistência. Quando o nativo da Amazônia se olha no espelho, vê lá no fundo dos seus olhos um sinal de que não foi feito para obedecer a certas leis, especialmente econômicas. Por isso, a leseira é algo alusivo, pode ser uma forma aguda de esnobismo ou uma ironia. Ela é, às vezes, pacífica; outras vezes, ostensiva, mas nunca rápida demais a ponto de ferir o ritmo do banzeiro, que é o ritmo regional (SOUZA, 1994, p. 125).

\subsection{A comunidade}

A comunidade se constitui como espaço organizativo peculiar, na qual seus membros estabelecem estratégias coletivas, com base na transmissão oral dos conhecimentos, na cooperação e num modelo singular de gestão dos recursos. Assentada sobre um território que inclui terras e águas, cada comunidade possui peculiaridades, decorrentes da sua história, da relação com a natureza, da capacidade de resistência, do modo como se relaciona com o novo e como as inovações atingem o lugar. A produção deste espaço depende não apenas das 
relações de produção, mas de outras dimensões como a política, a religião e o lazer. O ordenamento concreto de uma comunidade, em certa medida, representa a afirmação explícita da capacidade de expor suas prioridades, de identificar novos usos, desenvolver técnicas simples, e modos mais adequados às suas necessidades (CHAVES, 2002).

Especificidades que não são apartadas da vida urbana. Segundo Oliveira, J. (2003), um espaço humano que se produz num lugar qualquer da Amazônia não é único; ele está contido e contém uma totalidade que inclui tanto o processo de desenvolvimento recente para a região, como a forma de produção da sociedade nacional.

Para Harris (2006), a história amazônica produziu um modo de ser que se tornou característico das comunidades ribeirinhas. Uma população heterogênea que se movimenta entre áreas rurais e urbanas, num cotidiano de descontinuidades ambientais e econômicas. O que caracteriza essas comunidades é a grande capacidade de negociar as condições do presente, combinando o que é local com aspectos das culturas envolventes. A capacidade de abraçar a mudança a cada nova fase, sem que isso resulte no fim do seu modo de vida corrente. Moderno e tradicional se fundem, na constante renovação do passado, no presente. Mais do que se limitar ao conceito de cultura ou identidade, o autor destaca que a heterogeneidade, a ambivalência e a abertura diante do novo produzem o que há de mais rico nessas sociedades.

Tradicionalmente, a paisagem comunitária é formada por um conjunto de aproximadamente trinta a quarenta unidades residenciais, distribuídas ao longo das margens das águas, algumas agrupadas, outras mais dispersas, isoladas entre si. As residências são feitas de madeira e cobertas por telhas de alumínio ou amianto; poucas são as que ainda são cobertas por palha. Há uma área de uso comum, onde se localizam uma igreja, uma escola de Ensino Fundamental, um campo de futebol e um chapéu de palha ou sede comunitária para reuniões e festividades. Esta área representa a centralidade da comunidade, no que se refere às decisões a serem tomadas, não importando sua localização (CRUZ, 2007). Algumas comunidades também possuem uma área de uso comum para a produção de roças, viveiros ou criação de animais.

Como forma de organização política autônoma, as comunidades são inovações recentes, e têm tido maior visibilidade nos últimos trinta anos. A igreja católica influenciou de modo significativo nesta produção. O próprio termo comunidade passou a ser mais amplamente utilizado a partir da década de 1960, com o surgimento das Comunidades Eclesiais de Base - CEBs, em substituição à denominação "vila", termo anteriormente utilizado para referir-se a estas localidades (CRUZ, 2007). Na linha da opção preferencial 
pelos pobres e com base nos princípios cristãos, no bem comum e na transformação da realidade social, as CEBs promoveram a organização e formação de líderes comunitários, priorizando o trabalho nas áreas consideradas desassistidas e excluídas de toda e qualquer política social por parte do Estado, estimulando também a organização de associações de moradores e de produtores, além de núcleos e encontros regionais, na tentativa de aproximar as comunidades. Espaço privilegiado de reprodução das relações sociais, as comunidades se constituíram em possibilidades para a ampliação da intervenção do Estado e de organizações não governamentais, que passaram a se apropriar do termo. Conforme Pereira, Henrique (2003), a partir dos anos 1990, as associações de produtores e agências governamentais adotaram a fórmula, criando diversas comunidades, e reforçando a busca por infraestrutura, principalmente por educação. Este processo vem imbricado em múltiplos agentes e diferentes práticas sociais.

A religiosidade é outro fator na rotina das comunidades ribeirinhas, ainda predominantemente católicas. O diferencial nesta religiosidade é a relação entre devoção aos santos, crença nos encantados e rituais de pajelança, numa mistura em que pajelança e catolicismo não se contradizem. A presença das igrejas evangélicas e pentecostais tem aumentado consideravelmente nos últimos anos, carreando uma nova configuração.

As comunidades católicas geralmente recebem a denominação de um santo, que é considerado seu padroeiro, e para o qual se prepara um grande festejo, que envolve divisão de tarefas entre as famílias, busca de patrocinadores e convites a outras comunidades e representantes da municipalidade. Este evento exprime, de uma só vez, toda espécie de instituições: religiosas, econômicas, políticas, morais, estéticas, estreitando laços de cooperação e amizade, promovendo a aquisição de fundos e demarcando relações de poder no interior da comunidade.

Nas comunidades evangélicas, as denominações são bíblicas, como Vale do Sinai, Monte Horeb, Jesus me deu, e outros. Não possuem sede comunitária nem festejos para santos padroeiros, embora relações de compadrio e pajelanças ainda estejam presentes entre alguns membros da comunidade e, em certos cultos religiosos, festas e cantorias são permitidas como forma de louvor. Práticas de ajuda mútua são também comuns e frequentes entre os membros evangélicos.

Embora as comunidades ribeirinhas sejam essencialmente cooperativas e solidárias, não se pode deixar de considerar as formas ideológicas e iniciativas que permeiam as relações, e que muitas vezes reproduzem desigualdades sociais. Não há comunidade pura nem espaço homogêneo, novas situações são frequentemente produzidas na multiplicidade do 
cotidiano, com interesses divergentes, conflitos ou mesmo violência (SILVA, 2007; CRUZ, 2007; ADAMS; MURRIETA, 2006; CHAVES, 2004). Como em outras localidades brasileiras, há espacializações assinaladas pela contradição: de um lado, as ilhas de luxo, riqueza e bem-estar e, de outro, os arquipélagos de extrema pobreza (OLIVEIRA, J., 2003).

$\mathrm{Na}$ atualidade, alterações significativas vêm impactando as comunidades ribeirinhas, tanto no que se refere às questões ambientais até então ausentes do cotidiano destas localidades, quanto às suas próprias formas tradicionais no enfrentamento dos problemas econômicos, ecológicos e sociais. Um processo de reordenamento, que conjuga resistência e adaptação, e que pode ser visualizado em diferentes esferas da vida familiar, religiosa, das relações de vizinhança e do trabalho (CHAVES, 2004; PEREIRA, Hamida, 2006). Na composição desta paisagem, consideram-se os efeitos decorrentes da expansão urbana, da implantação do sistema rodoviário e das práticas escolares via escolarização formal.

Para os povoados que estão se aproximando e sendo integrados à urbe pela malha rodoviária, tudo se modifica: abrem-se novos acessos, muda-se a demarcação do tempo, produzem-se novas necessidades de consumo. $\mathrm{O}$ acesso facilita a migração, mas também a introdução de problemáticas típicas da vida urbana, como violência, criminalidade, prostituição e drogadição. Costumes como reunir-se ao fim da tarde para conversas são substituídos pela vida privada, e relações de vizinhança e compadrio vão sendo ressignificadas, diminuindo os laços de solidariedade (PEREIRA, Hamida, 2006).

Há mudanças na espacialidade. As ocupações recentes têm constituído outro formato, retangular, padronizado, com casas mistas e telhas de alumínio, em terrenos pequenos, cercados, e organizados em quadras, instaladas sob forma de assentamentos urbanos em áreas rurais.

A expansão do capital altera sistematicamente as economias locais, mas não tem proporcionado melhorias nas condições de vida e relações de trabalho. As comunidades têm migrado para o uso de estratégias econômicas univalentes, e as atividades coletivas vão sendo substituídas pela lógica do trabalho individual inerente ao capitalismo. O emprego assalariado é percebido como garantia de vida segura, principalmente para os mais jovens, que são estimulados a buscar, na indústria ou no comércio, melhores oportunidades de emprego e renda. Entretanto, em função da baixa escolaridade, passam a compor quadros de menor remuneração, submetendo-se à exploração. E como o mercado não absorve toda a força de trabalho disponível, surge nas comunidades a figura do desempregado (PEREIRA, Hamida, 2006). 
O tempo destinado ao percurso casa-trabalho se modifica, acrescentando longas horas de espera por transporte coletivo. O balanço entre horas de trabalho, descanso e lazer vai sendo substituído pela agitação da urbanidade e por extensas jornadas de trabalho.

Nas relações com o ambiente, figura maior pressão sobre os recursos naturais, cenário envolto em um discurso híbrido e insustentável da "sustentabilidade", que privilegia a lógica empresarial homogeneizadora, e minimiza/desqualifica o acúmulo dos saberes tradicionais.

A educação formal tem sido convidada, desde $1977^{10}$, a intervir no sentido de sensibilizar as populações, para reverter este modelo predatório de relacionamento com o ambiente. No meio rural, enfatiza-se seu caráter mediador entre o conhecimento técnicocientífico universalizado e a realidade local. Entretanto, questiona-se se o modelo escolar presente nestas comunidades tem favorecido a construção de práticas que efetivamente contribuam para este relacionamento.

\subsection{A escola}

Moreira (1993), ao analisar as mudanças ocorridas em uma comunidade pesqueira, fala das relações com a escola formal. Essa instituição, conforme o autor, constitui-se em um elemento de caráter desarticulador da relação relativamente integrada entre o ser humano e o seu meio circundante, ao propugnar valores predominantes na metrópole; todavia, ao mesmo tempo, é tida como um elemento atenuante dessa desarticulação, na medida em que se apresenta como uma via de mobilidade social para os membros dessa comunidade, em particular, para os mais jovens. A escola formal tem sido considerada uma via principal de ascensão social, representando uma abertura para maiores possibilidades de trabalho e renda. Para alunos, seus pais e mesmo professores, a escola é vista como a única forma de adquirir meios para superar os problemas econômicos, sociais e étnicos. Entretanto, esta melhoria não se apresenta visível, visto que a maioria dos alunos não consegue ultrapassar o Ensino Fundamental.

A escola é reconhecida como veículo difusor de conhecimentos que auxiliem a superar o suposto atraso decorrente da vida campesina. Em estudos realizados com pais de alunos em comunidades rurais, verificou-se a preocupação em relação ao conhecimento da língua, da matemática básica, como uma forma de "lapidar" a criança, inserindo-a no meio social, e como um caminho para enfrentar novas situações decorrentes da modernização do campo

\footnotetext{
${ }^{10}$ Faz-se, aqui, referência à Conferência Mundial sobre Educação Ambiental, ocorrida em Tbilisi, em 1977.
} 
(HASHIZUME; LOPES, 2008; RIBEIRO, 2005; DAMASCENO; BESERRA, 2004). Os camponeses admitem a importância da escola para a formação de seus filhos, e dela esperam modos alternativos de conhecer e construir relações sociais, culturais e de trabalho, assim como a capacidade de relacionar o saber popular camponês ao saber sistematizado.

Emergindo nos movimentos sociais, há também os que enfatizam a importância da escola como um componente essencial no apoio à emancipação e luta pela terra. Neste caso, assumem uma postura bastante crítica no que diz respeito ao tipo de escola existente no meio rural, com sugestões visando à construção coletiva de uma escola sintonizada com os interesses dos povos campesinos. Damasceno e Beserra (2004) e Ribeiro (2005) situam nesse movimento - em que a terra, vista como projeto de vida e de trabalho pelo qual lutam, é também a terra com a escola -, a perspectiva de uma escola que vise à formação do trabalhador rural, com competência para enfrentar os desafios da produção e da vida contemporânea. Retomam, assim, o sentido de educação como algo que transcende à mera instrução a que se restringe a escola rural, configurando o que passou a se chamar educação do campo.

No meio rural, há muitas dificuldades para frequentar a escola. Os alunos deparam-se com as baixas expectativas dos professores e situações pouco estimuladoras para a aprendizagem, com a transmissão de conhecimentos desconectados da realidade por eles vivenciada, em classes multisseriadas que oferecem, na maioria das vezes, apenas a primeira etapa do Ensino Fundamental. Isto se acentua, em muitos casos, pela condição de aluno trabalhador rural, pelo isolamento geográfico e os longos percursos entre local de moradia, trabalho e escola, ou ainda a necessidade de as famílias se deslocarem para lugares mais distantes, em busca de terra e trabalho. O sistema escolar oferece outras restrições, tais como a dificuldade de transporte escolar, de recursos, de profissionais qualificados, condições de trabalho; além disso, em alguns lugares, há a dissonância entre a sazonalidade da produção e o calendário escolar (HASHIZUME; LOPES, 2008). Esses problemas concorrem para os altos índices de evasão, repetência e distorção idade-série.

Para Ribeiro (2005), a educação dos filhos tem representado historicamente um grave dilema para os camponeses. Muitas famílias deixam a terra e vão para as periferias das cidades em busca de escola, que pode significar uma oportunidade de emprego assalariado para os filhos. Porém, mesmo para as famílias que enviam seus filhos para a escola rural, o ensino feito através desta escola não os prepara para permanecer na terra. A autora acrescenta que o desafio atual é ainda maior, tendo em vista que as novas tecnologias que se refletem sobre o trabalho e a educação estão longe de chegar à escola rural. Ainda assim, considera que 
a escola pode ser um instrumento de perda, ou de luta pelas condições de vida no campo, "um mecanismo com grande potencial para assumir a tarefa de energizar e empoderar os trabalhadores rurais em suas lutas políticas" (OLIVEIRA, L, 2005, p. 19). Mesmo com limites e dificuldades, a escola tem se tornado uma das instituições mais desejadas e requisitadas, tanto no que se refere à divulgação do saber universal para os povos rurais, como na compreensão e resolução dos problemas do campo.

Assim sendo, a escola constitui-se ora em um ambiente valorizado, lugar de (trans)formação, contribuindo para elevar o nível de aspiração da população, que nela deposita a esperança de melhores condições de vida e de posição social, ora em um ambiente desvalorizado, pois a precariedade e baixa qualidade do ensino fazem com que a aquisição do diploma não signifique reais oportunidades de inserção no mercado de trabalho ou de melhoria da produção local.

Numa comunidade rural ribeirinha, a família e a escola são os agentes educacionais mais expressivos. Representando uma primeira forma de vivência diferenciada da família, a escola se fortalece como espaço de produção da hegemonia e reprodução dos valores e cultura dominantes, provocando significativo impacto na vida das pessoas e da comunidade.

Moreira (1993) observa, no que se refere à expectativa gerada pela escola formal, que os pescadores veem a escola como o "meio de inserção social", vislumbrando, portanto, uma mobilidade social para seus filhos. Em geral, a escola é qualificada como um local onde se aprende a ler e escrever, não sendo, portanto, concebida como uma instituição profissionalizante. À família cabe, além da transmissão e socialização de valores, a responsabilidade pela formação profissional.

Visbiski e Weirich Neto (2004) concordam, afirmando que a escola é reconhecida como um agente profissional de mínima importância. A escola é compreendida como o lugar da contraeducação rural, onde a criança aprende a deixar de "lidar com a terra". A escola não é compreendida como um agente de formação profissional, mas de informação daquilo que é necessário adquirir para aprender uma profissão: ler, escrever e contar.

Mas, para Moreira (1993), a escola, deixando de contribuir para a profissionalização dos membros da comunidade, no que diz respeito às atividades produtivas básicas ali exercidas, deixa também de facilitar a integração desses mesmos indivíduos com o seu ambiente, modo de vida peculiar e universo cultural.

Acenando com possibilidades de melhores condições de vida, através do acesso a melhores oportunidades de trabalho, a escola minimiza o impacto da desarticulação do universo social, econômico e cultural, e estimula o 
conformismo e a passividade diante desse processo. Distante da realidade local, a escola torna-se um canal que facilita a inserção dos indivíduos da comunidade ribeirinha em outra realidade diversa daquela por eles produzida. Não os prepara sequer para usufruírem os benefícios do ambiente, de onde poderiam extrair vantagens que redundassem na elevação do padrão de vida e melhoria das condições de existência humana (ibidem, p. 129).

Oliveira, L. (2005, p. 24) também faz uma referência neste sentido, salientando que o setor rural "carece de escolas que valorizem e dignifiquem os agricultores e o mundo rural", que ajudem a identificar os recursos e as oportunidades existentes em seu próprio meio, ou a transformar as potencialidades em atividades econômicas sustentáveis.

Outro aspecto relevante é o fato de que as escolas rurais, de modo geral, apresentam padrão curricular similar ao adotado pelas escolas citadinas. Percebe-se, na escola rural, que a formação dos educadores, o currículo, a linguagem, as atividades realizadas referem-se à cultura do espaço urbano, considerada como superior, enquanto que a realidade do mundo rural é considerada arcaica. Este processo parece estar direcionado à formação de condutas e valores exigidos pelo mercado, para formar a mão-de-obra "adequada" ao emprego assalariado nas cidades, ou mesmo para transformar o homem do meio rural em consumidor de bens materiais. Neste sentido, agricultores e seus filhos estão inseridos em um ambiente escolar em que a única ligação estabelecida com as suas vivências é o fato de a escola estar situada na zona rural.

Isso leva a reproduzir uma ideologia que reforça a assimilação de um novo modo de vida urbana percebida pelos membros da comunidade, em particular pelos mais jovens. A escola exerce significativa influência nos papéis sociais, nas relações intrafamiliares e de trabalho, servindo de veículo eficaz na manipulação externa e contribuindo para descaracterizar culturalmente a comunidade. Alienada da vida rural, e propagandeando a superioridade da vida urbana, a escola rural funcionou (e ainda funciona) mais como motivo de migração para a cidade do que como instrumento de produção coletiva de transformação da realidade. No dizer de Reis Neto (2005), aprender a ler, escrever, tirar as contas e migrar para cidade.

Para Hashizume e Lopes (2008), a escolarização rural foi e ainda é, de certa forma, vista preponderantemente pelos diversos governos brasileiros como um prolongamento da escolarização urbana, e vários estudos assinalam que, até recentemente, o sistema educacional não tinha como preocupação fomentar políticas educacionais eficientes para atender às demandas do campo. 
Um rápido olhar pela trajetória do ensino rural, no Brasil, permite perceber que este tem refletido as necessidades que foram surgindo em decorrência das políticas fundiárias e das estruturas socioagrárias do país. A formação social inicial, baseada no regime de escravidão, no latifúndio e no predomínio da produção extrativista, não demandava qualificação da força de trabalho. Com o advento da monocultura cafeeira e com o processo de modernização do campo, emergem demandas de mão-de-obra mais especializada. O ensino rural vai sendo lentamente introduzido, no bojo das necessidades econômicas do setor primário e das interpretações politicoideológicas da oligarquia agrária.

Pode-se afirmar que o ensino regular em áreas rurais emergiu no final do segundo império. Encontra-se alguma referência destacando a importância de um ensino voltado aos agricultores, nos Planos de Educação anteriores à República ${ }^{11}$, mas foi somente após a década de 1920 que ações mais expressivas foram implantadas, haja vista a forte migração de camponeses em busca de trabalho, no emergente processo industrial, nos centros urbanos. Damasceno e Beserra (2004) chamam atenção para o fato de que, paradoxalmente, esta preocupação das políticas do Estado com a escolarização rural coincide com o momento em que as atenções se deslocam para o desenvolvimento industrial urbano.

Assim sendo, objetivando promover a reversão dos fluxos migratórios e convencer os trabalhadores rurais de que seu papel no processo de desenvolvimento era o de "garantir o sentido da vocação agrícola do país”, vários programas foram implantados. Dentre eles, as ideias do ruralismo pedagógico, a criação da Sociedade Brasileira de Educação Rural em 1937, programas de extensão rural, e a Campanha Nacional de Educação Rural, na década de 1950 (LEITE, 2002).

Tomada como "peça chave para o desenvolvimento do país", os direcionamentos dados a esta educação estavam comprometidos com a ideologia do mercado, e orientados para a criação dos cursos profissionalizantes de formação técnica, visando atender às necessidades do processo de industrialização e do capital. Primavam pela imposição de conhecimentos produzidos em outras realidades, e pela constante referência ao urbano como modelo de desenvolvimento: desde os professores que funcionam como decalques a imprimir novos valores às comunidades, até à organização de atividades e conteúdos curriculares. Trata-se de um modelo que "omite a existência dos trabalhadores rurais ou, quando faz menção à sua existência, é para demarcar, nas entrelinhas dos artigos, discursos e recomendações, a sua

\footnotetext{
${ }^{11}$ Refere-se, aqui, aos Planos de Educação de 1812, 1826 e 1879 que destacavam a importância de um ensino voltado aos agricultores, com conhecimentos sobre horticultura, lavoura e geologia, em nível médio. Para maior aprofundamento sobre o tema, remete-se a Calazans, 1993, Leite, 2002; e Ribeiro, 2005.
} 
diferença, o seu atraso, a sua incapacidade, a sua ignorância, seus modos primitivos, a sua até - falta de higiene" (RIBEIRO, 2005, p. 4).

Oliveira, L. (2005) fala que talvez por isso, nenhuma das ações até então implementadas para resolver a questão da escolaridade rural mostrou-se efetiva, posto que não contemplavam as especificidades do homem rural, seu contexto, sua ligação com o ambiente natural e com o processo produtivo, reduzindo seus valores culturais a uma espécie de "folclore que se estuda".

Tem-se, portanto, conforme salienta Porto (1994), que no Brasil os planos e projetos para a educação rural foram influenciados ou por uma vertente culturalista, que tem como pressuposto a concepção ocidental e etnocêntrica de cultura, visando ao enquadramento do diferente, ou por uma vertente economicista, que tem como postulado seu atraso frente às condições socioeconômicas e políticas gerais, bem como culturais, sendo impossível superar tal atraso, sem a ajuda de especialistas. Assim, a escola assume o papel de promover uma mudança de comportamento do homem rural, sejam quais forem os objetivos, parecendo estimular a produção de estruturas organizadas de esquecimento com relação ao saber tradicional.

Para Ribeiro (2005), embutido nas propostas para a educação rural, há o movimento de desestruturação da produção camponesa, tanto para a formação de um mercado de força de trabalho quanto para a constituição de condições para a modernização da produção agrícola. Intencionalmente ou não, isto contribuiu para que os agricultores perdessem a autonomia do conhecimento e da produção de sementes, matrizes, adubos e aplicação de suas próprias tecnologias e ritmos de trabalho.

Por outro lado, chama-se a atenção para o fato de que, mesmo com os esforços de implantação de um sistema escolar homogêneo, nenhuma tendência foi absolutamente hegemônica, e diversos programas de educação rural serviram de instrumentos de difusão de ideologias, inclusive opostas às pretendidas pelo governo. Conforme Damasceno e Beserra (2004, p. 4),

Semeados numa sociedade em transição e marcada por extraordinária desigualdade social, tais projetos e políticas têm consequências as mais diversas, inclusive a de mobilizar as populações rurais já vítimas da modernização no campo, contra os efeitos negativos que esta vem produzindo sobre as suas vidas. É o caso do conjunto de movimentos sociais que, articulados aos partidos políticos de esquerda ou à Igreja católica, vão produzir um estilo de educação e um tipo de saber bastante diferente dos pretendidos pelas necessidades imperialistas, entre os quais se destaca a Pedagogia de Paulo Freire que vai, depois, influenciar uma das tendências acadêmicas do estudo do rural: a da educação e movimentos sociais no campo. 
Estes movimentos tomam impulso a partir da década de 1990, e iniciam um processo de redefinição do significado da escola rural na vida dos sujeitos, e da função social da escola nas dinâmicas dos seus contextos. Criticando a implantação do currículo urbano nas escolas rurais, enfatizam uma proposta de escola básica do campo "que não está pronta, não é fechada, nem é imposta", em que o conteúdo curricular e as metodologias de ensino estejam conectados às necessidades e interesses dos alunos, valorizando, dentre outros aspectos, a cultura dos povos que vivem no campo, em suas especificidades e modos de vida. Também se pode falar das diversas microações, experiências singulares, que pontuam as práticas silenciosas de professores e alunos, e que não estão vinculadas a nenhum modelo ou programa. Movimentos instituintes, soerguendo-se entre as lacunas das políticas públicas existentes, na tentativa de irromper novos compassos nas relações culturais, escolares e sociais, forçam mudanças nas políticas para o setor rural.

Uma primeira ação em se definir uma política de educação rural pode ser indicada pela Lei 4024/61. Mas, apenas após o surgimento da Lei de Diretrizes e Bases da Educação, Lei no 9394 de 1996, é que se estabeleceu, na oferta da Educação Básica para a população rural, que os sistemas de ensino devem promover a necessária adequação às peculiaridades da vida rural e de cada local, no que diz respeito aos conteúdos curriculares e metodologias apropriadas às reais necessidades e interesses dos alunos da zona rural, organização escolar própria, incluindo adequação do calendário escolar às fases do ciclo agrícola e às condições climáticas, e adequação à natureza do trabalho na zona rural (BRASIL, 1996).

Para Benfica (2006, p. 45),

[...] ao submeter o processo de adaptação à adequação, a LDB institui uma nova forma de sociabilidade no âmbito da política de atendimento escolar: a legislação reconhece a diversidade sociocultural e o direito à igualdade e à diferença, possibilitando a definição de diretrizes operacionais para a educação rural sem, no entanto, recorrer a uma lógica exclusiva e de ruptura com um projeto global de educação para o país.

A legislação inova quando chama atenção para as potencialidades da vida rural e de cada região, quando atenta para o reconhecimento da diversidade sociocultural, quando se posiciona em relação à igualdade e diferença. Observa-se a recomendação para considerar, no âmbito dos conteúdos e metodologias, os processos de aprendizagem dos alunos, bem como as especificidades do campo. Entretanto, percebe-se um distanciamento entre o que a lei preconiza e o que de fato se efetiva para a população como um todo. 
A universalização do Ensino Fundamental é uma conquista em termos de política pública, mas mesmo tendo decrescido significativamente o déficit de cobertura escolar nas áreas rurais, a qualidade educacional oferecida se mantém como um desafio para o poder público e para as comunidades, insuficiente, segundo Hage (2005), para constituir-se em fator estratégico diferenciador.

Há um distanciamento entre a escola e o mundo local. As práticas educativas, muitas vezes descontextualizadas, são desprovidas de sentido para os ribeirinhos que, apesar de deterem um vasto conhecimento sobre a floresta e seus recursos, este conhecimento não é valorizado, ou, ainda, é desqualificado. Diegues $(2005 ; 1994)$, analisando o tratamento dado pelo poder público às populações tradicionais, diz que, subjacente a essa discussão, está a questão do controle do poder sobre o conhecimento científico e como este reforça as estruturas de poder. Reconhecer a importância do saber tradicional é, implicitamente, reconhecer que os povos tradicionais são sujeitos históricos, que devem ser considerados como agentes fundamentais na produção de conhecimento e, sobretudo, na gestão de seu lugar.

Torna-se imperativa, segundo Leite (2002), a incorporação do saber elaborado e vivenciado pelas populações campesinas a uma prática educacional que pretenda dar conta de recolocar a dimensão sócio-histórica do campo e seu papel como "força emergente". Isto vale, também, para os diferentes contextos sociais. Faz-se referência à necessidade de resgate e acatamento das experiências campesinas (manifestações linguísticas, simbólicas, artísticas, medicinais, de trabalho/produção, alimentação, sobrevivência), para que, apreendendo e respeitando o conjunto de elaborações e valores subjacentes ao modo de vida do rurícola brasileiro, se possa contribuir para a implantação de políticas não apenas de acessibilidade ao ensino e à qualidade de vida, mas que também favoreçam a permanência nesse contexto, bem como pela troca de saberes e experiências, repensar as possibilidades ético-estético-políticas de nosso próprio modo de vida.

\section{Análise institucional, posição e contraposição}

O suporte teórico-metodológico desta pesquisa baseia-se nos fundamentos da Análise Institucional. Considerada um movimento, foi inicialmente proposta por Lourau e Lapassade, e, de outra parte, por Guattari, como um método para decifrar as relações que indivíduos e grupos mantêm com as instituições. Sua emergência está relacionada a práticas microssociais 
relativas à Psicoterapia, à intervenção psicossociológica e à Pedagogia, que trazem como função estratégica instaurar uma abertura no campo analítico, até então restrito à ação dos especialistas psi e à consideração de fatores psi.

Como abordagem singular e multirreferencial, predominantemente sociológica, foi se estabelecendo como corpo teórico e estratégias de intervenção, a partir de experiências concretas e de um constante processo de autoanálise e avaliação.

Para Rocha, M. (2007), a Análise Institucional apresenta-se como uma ferramenta necessária para a compreensão do que se passa em diversos campos de intervenção dos trabalhadores sociais, entre estes os que facultam encontros da Psicologia com a Educação, já que cada vez mais estão postos em questão os limites dos saberes/práticas de que se dispõe e suas possibilidades de interferir na realidade sócio-político-institucional. Apresentar-se-ão, a seguir, algumas considerações acerca dos principais conceitos que subsidiam a pesquisadora, na construção deste trabalho.

A Análise Institucional formula a ideia de pesquisa-intervenção, questionando os sentidos cristalizados nas instituições, sendo estas o conjunto de práticas que atravessam todas as relações sociais. Propõe-se, como um método de intervenção em situação, analisar as relações que as múltiplas partes presentes no jogo social mantêm com o sistema manifesto e oculto das instituições, bem como afetar os espaços de poder constituídos, de modo a potencializar a promoção de novos territórios. Assume manifestamente seu conteúdo político e, como seus autores enfatizam, o método não é só uma questão de procedimento, mas uma postura frente ao trabalho, ao outro, à vida.

Lapassade (2005), L’Abbate (2003) e Rodrigues (2005a) consideram que, desde o início, não houve apenas uma maneira de definir ou praticar a análise institucional, já que esta se situa no entrecruzamento de diferentes disciplinas, como Filosofia do Direito, Marxismo, Sociologia, Psicologia Social, Psicanálise, Pedagogia e Psicossociologia, e de movimentos que emergiram na sociedade francesa desde fins da década de 1940. Pelo menos duas, eminentemente distintas, podem ser citadas: a primeira, formada a partir da Psicoterapia Institucional francesa, visando à renovação dos hospitais psiquiátricos, e a segunda, a partir da Psicossociologia Clínica dos grupos e das organizações, propondo análise conduzida de dentro dos estabelecimentos, análise coletiva do grupo centrado sobre o grupo.

Dentro do Institucionalismo francês, destacam-se a Socioanálise, sobretudo com Lourau e Lapassade, e a Esquizoanálise, inspirada na Filosofia da Diferença, relacionada a Guattari e Deleuze. No Brasil, o movimento institucionalista ganha força na década de 1970, a partir de alguns departamentos e grupos de pesquisa de universidades brasileiras e de outras 
organizações, congregando os mais diferentes tipos de profissionais, inclusive pensadores argentinos, que aqui se refugiaram de perseguições políticas. Na produção brasileira, provocaram-se misturas; é difícil reconhecer limites precisos entre seus diferentes campos, dada a interdependência de conceitos entre eles. Rodrigues (2005a, p. 29) diz que a Análise Institucional, no Brasil, "é polifônica: fala francês (Belo Horizonte), espanhol com sotaque portenho (Rio de Janeiro) e italiano (São Paulo)", evidenciando nosso timbre e ritmos próprios ligados às vicissitudes econômicas, políticas e culturais do país.

Mesmo havendo uma heterogeneidade de tendências institucionalistas, que trabalham com configurações distintas e ora esbarram em impasses, tensões, ora em aproximações, há em comum a defesa da ruptura com o modo positivista de investigação/intervenção, e a afirmação da relação pesquisa e política, educação e política, e das redes de poder. Postulam intervir em grupos, comunidades, organizações e instituições, potencializando movimentos onde se manifesta a estagnação. Intentam transformar as instituições pela ruptura com o instituído, com os especialismos, profissionalismos e cientificismos historicamente cristalizados, constituindo-se como ferramenta metodológica em que as perspectivas dos sujeitos, das subjetividades e da autonomia estejam respeitadas e promovidas, e também, elas mesmas, colocadas "em análise". Com o apoio de autores do campo da Psicologia, propõe-se compor este trabalho sob a perspectiva do Institucionalismo, modo como Aguiar e Rocha (2007, p.655) têm nomeado "os encontros pulsantes e não menos problemáticos, especialmente entre a Socioanálise e a Esquizoanálise" acrescidas de contornos foucaultianos.

De acordo com Lourau (2004a), as instituições formam a trama social que une e atravessa os indivíduos, os quais, por meio de sua práxis, mantêm estas, e criam outras. Aparecem como algo não localizável. São normas, incluindo a forma como os indivíduos concordam ou não em participar delas. São também as constituições políticas, as leis, e revestem os aparatos encarregados da execução e controle destas leis. São práticas sóciohistoricamente produzidas que trazem a dimensão dos valores, das tradições, da referência das ações e que, no cotidiano, são naturalizadas e tomadas como verdades absolutas, universalizadas (ROCHA, M., 2006a).

São manifestações e concretizações das realidades da vida em sociedade, que tendem a se repetir, que não são questionadas quanto a suas condições históricas de produção e reprodução e, assim legitimam-se. Tomam o cotidiano, estando presentes até nas ações aparentemente menos significativas. De tal forma que não há vida social fora das instituições e sequer há instituição fora do fazer humano (GUIRADO, 1997). Queiramos ou não, estamos sempre implicados em instituições. 
Lapassade (1983) e Lourau (1993) assinalam que a instituição não se confunde com os dispositivos ou as instalações materiais. Em seu movimento histórico, este termo esteve associado a formas sociais particulares concretas (estabelecimentos), jurídicas (organizações), e a formas de organização das práticas, como grupos, oficinas, e outros. Mas Lapassade enfatiza que a instituição não é um nível ou uma manifestação da formação social, mas a maneira mesma como a realidade social se organiza, sobredeterminada pelo Estado, que dispõe do aparato jurídico, fixa a burocracia e regula o funcionamento das organizações.

As organizações são, assim, entendidas como as instâncias que têm existência material e jurídica, e que fazem a mediação entre a base e o Estado. São o nível dos aparelhos, da transmissão de ordens, da organização burocrática; e cumprem sua função de normatizar a vida humana, assegurando o controle social ao poder central (LAPASSADE, 1983). Para ser entendida, a própria organização demanda levar em conta as instituições que a atravessam, que não são acessíveis, e que se manifestam, por exemplo, na divisão e quantificação do tempo, do saber, do certo e do errado, do trabalho e do poder a ele associado.

As instituições se instrumentalizam nas organizações e nas técnicas, sendo nelas produzidas, reproduzidas, transformadas e/ou subvertidas (FERNANDES; ROZENOWICZ; FERREIRA, 2004). Portanto, não são compreendidas como estabelecimentos ou estruturas organizacionais. Materializam-se em dispositivos concretos, que são as organizações, e embora não precisem de estabelecimentos para existir, sempre se estabelecem, criam suas leis, suas regras, seus códigos, suas ideologias. Impõem costumes, prêmios e punições, transmitem valores e estabelecem limites. E não atuam de fora para dentro; elas atravessam todos os níveis dos conjuntos humanos, como parte da dinâmica simbólica do grupo, do indivíduo. Para Lourau (1993), há nas instituições um sentido ativo: manter de pé a máquina social e produzi-la.

Faz-se aqui uma consideração relevante: a instituição é o dado, mas também é produção. Lapassade (2005) observa que a palavra instituição (na França e assim também no Brasil), possui um duplo sentido: designa ao mesmo tempo uma ordem instituída, estabelecida, e o ato de instituir, criar, estabelecer. Para o movimento institucionalista, a dinâmica institucional envolve necessariamente a relação instituinte-instituído.

O instituído é entendido como a ordem estabelecida, os valores, modos de representação e de organização considerados normais e, igualmente, os procedimentos habituais de previsão. É o que se impõe como uma verdade não produzida, correspondendo à ideia de universalidade abstrata. Isto porque a ordem instituída produz como efeito o "esquecimento" de suas origens, a "repressão social" do conhecimento acerca dos conflitos de 
interesse que presidiram o processo de institucionalização. Em consequência, as instituições se naturalizam. São vistas como fixas, universais, como um dado social, uma condição necessária e trans-histórica da vida das sociedades (LOURAU, 1979). Mas todo instituído é resultado de um processo de produção anterior, que se estabilizou. $\mathrm{O}$ que indica que há forças produtivas que irrompem a todo momento e que são responsáveis por novas processualidades. É o instituinte, o negativo, entendido como a contestação, a capacidade de inovação e, em geral, a prática política como significante da prática social. Posto que a instituição só sobrevive alimentando-se do sangue novo que lhe vem do exterior (LOURAU, 2004b), está continuamente exposta à renovação. Isto, todavia, não se configura suavemente, pois o instituído atua com um jogo de forças extremamente violento para produzir imobilidades, manter a ordem e o status quo, reparar desvios e divergências (COIMBRA, 1995).

A instituição necessita do poder instituinte do homem. Se este sofre as instituições, também as cria e as mantém por meio de um consenso que não é só passividade frente ao instituído, e sim atividade que pode lhe por em questão, e que dela faz parte, posto que toda instituição tem na contestação um de seus elementos.

Para o movimento institucionalista, a relação instituinte-instituído situa-se em uma contradição: o instituído é produto de um processo de produção e de criação de instituições, denominado instituinte que, por sua vez, é parte de instituições já existentes e são forças produtivas de códigos institucionais. Afirma-se assim, a existência de um terceiro momento, que conecta os dois primeiros, e que é um produto transformado dessa primeira contradição: a institucionalização. Lourau enfatiza que longe de ser algo estático, fotográfico, as relações tecidas entre instituinte-instituído são paisagens, e movem-se em todas as direções: movimento constante de cores, formas, sons. Na dinâmica institucional, temos movimento e constância interagindo... movimento na constância; constância, no movimento. Tudo é movimento (LOURAU, 1993).

Processo e produto, a institucionalização é um estar permanente e significa o contrário de uma fixação, de uma paralisia, mesmo em períodos de ordem rígida e repressão, mesmo que nem sempre visível, e ainda que em luta constante com as forças de autodissolução. É autoalteração perpétua da sociedade como constituindo seu próprio ser. Lapassade (1983) diz que quando se admitem esses movimentos, o conceito de instituição se transforma e passa a ser um importante instrumento de análise das contradições sociais.

A própria Análise Institucional tem, na base de sua construção teórica, a lógica do movimento e da contradição: contradição na construção de um campo de coerência, que é multirreferenciado neste mesmo instituído; contradição entre instituído e instituinte, e no 
interior dos mesmos; contradição entre a institucionalização e o processo de autodissolução; contradição entre a auto e heterogestão. E deve permanentemente analisá-las, posto que só funciona dentro destas (LOURAU, 1993).

Para a Análise Institucional, toda relação social se faz nos grupos. Estes, por sua vez, podem vir a configurar organizações e são ambos, atravessados, e sobredeterminados pelas instituições (LOURAU, 2004a). São estes, os três níveis de realidade a serem considerados, e são também os termos que denominam os três níveis de análise. A Análise Institucional procura abordar o grupo na relação instituinte e instituído, estudando a organização como um lugar de produção e reprodução das contradições sociais.

Conforme Lapassade (1983), o grupo é o nível de base, o espaço/tempo da vida cotidiana. E desde este nível as relações são regidas por instituições. Em grupos permanentemente vivemos, há tarefas, responsabilidades, funções, regulamentos, sistemas de autoridade, e há também leis de funcionamento interno que nem sempre tomamos consciência.

O grupo não é estático, é ato. Não é um conjunto de pessoas organizadas por certas estabilizações de espaço e tempo, mas os processos que se constituem entre elas e a partir delas, no exercício permanente de buscar sentido para o desdobramento das ações e para o significado de sua própria existência. Assim, um grupo se faz na multiplicidade de tensões geradoras de transformações nas/das circunstâncias e no/do curso de seu movimento (ROCHA, M., 2006a).

Constitui-se por meio e no interior da dispersão que o precede, e se mantém graças a uma permanente luta contra uma volta sempre possível a esta dispersão. Tem forças de teor instituinte e, por isso, movimenta-se, mas, paradoxalmente, atua com forças reprodutoras de subjetividades e mantenedoras de certas relações instituídas, cristalizando-se, burocratizandose, legitimando organizações.

Ao tratar sobre grupos, Guattari (2006) os considera como modos sócio-históricos de funcionamento, e não como entidades, e apresenta duas vertentes entre esses modos, diferenciando grupos sujeitados e grupos sujeitos. Os grupos sujeitados recebem sua lei do exterior: há neles a adesão cega, a identificação dos seus membros com as instituições que determinam sua existência e atravessam sua estrutura, embora nem sempre tenham consciência desta identificação e até mesmo se recusem a reconhecer a existência destas mesmas instituições.

Os grupos sujeitos pretendem fundar-se a partir da assunção de uma lei interna e, em sua prática, apreendem a dialética das instituições que, do exterior, intentam fundar o seu 
interior. $\mathrm{O}$ autor propõe que a emergência de uma multiplicidade de grupos vá substituindo, desde a base, as instituições propostas pelas classes dominantes, transformando grupos sujeitados em grupos sujeitos, capazes de repensar sua submissão e criar suas próprias leis.

É no nível do grupo que se situa a prática da análise e da intervenção. A análise do grupo é um material privilegiado, pois permite medir o grau de identificação à instituição. Interferir entre grupo significa interferir diferencialmente na instituição.

Lourau (2004b; 1979) vê no grupo a possibilidade de contrainstituição. Para ele, o grupo pode recolocar as questões institucionais que estão em jogo, tanto do exterior, quanto no interior do mesmo, acessando e evidenciando suas condições de emergência e instauração, e seus modos de funcionamento.

Também sob esta perspectiva e apoiando-se no referencial esquizoanalítico, Saidon (1987) acolhe a concepção de grupo como dispositivo, ou seja, um instrumento que ponha a máquina em funcionamento, que permita aumentar o índice de transversalidade, ou ainda como máquina de guerra, que agencie o desejo e que possibilite ao grupo ser uma reunião de diferenças, expressão de singularidades e não apenas de similaridades.

Assim se pensou a pesquisa-intervenção: Os institucionalistas entendem a necessidade de um trabalho analítico que possa trazer à tona o que se faz invisível, o não dito, a face escondida das ações, rituais e práticas, que institui objetos e individualidades como algo em si mesmo. Interessa mapear os processos, e focar a atenção nos acontecimentos que se propagam na singularidade das situações cotidianas, nas situações que resistem aos modelos. Trata-se de resgatar as forças instituintes que a instituição busca eliminar, numa tentativa de naturalizar as normas, ideias e relações.

Como diz Rodrigues (2005a, p. 46), a Análise Institucional visa colocar em evidência as condições institucionais de existência de qualquer tema ou problema, "que se desprendam dos campos de intervenção instituídos - clínico, escolar, laboral, comunitário, de saúde - para gerar/inventar campos de análise desnaturalizadores".

Afirma a investigação como ato político, que não dissocia a gênese teórica e social de seus conceitos, e que se propõe de forma coletiva e autogestionária à produção de transformações no social. Aqui o transformar para conhecer pauta-se na perspectiva de que conhecer e intervir são planos indissociáveis.

A intervenção associa-se a pequenos grupos, e se caracteriza pela consideração de um campo de análise e um campo de intervenção que não se confundem, e que se encaixam como eixos indissociáveis. É microssocial e micropolítica, ou seja, “aponta para as experiências concretas, em que se estabelecem os conflitos entre o vivido e os modelos formulados na 
lógica geral instituída" (ROCHA; UZIEL, 2008, p.538). Mas não se dissocia das macroanálises, que são fundamentais para situar as forças conjunturais que atravessam as práticas sociais (ROCHA, M., 2006a). É preciso atentar para os limites de se discutir apenas as dimensões sócio-político-institucionais hegemônicas. Como Lourau (1993) enfatiza, não se pode contentar em ver apenas as grandes contradições. É preciso observar a contradição no micro, no interior do instituído e inclusive, no interior do instituinte. É preciso ver as nossas próprias contradições, as nossas implicações.

Como prática micropolítica, a pesquisa-intervenção põe em discussão os percursos que vêm sendo produzidos a partir de seus efeitos. Rodrigues (2005b) situa esta questão dizendo que a Análise Institucional prefere os efeitos às leis. Faz uma decidida opção antipositivista, rompendo com os enfoques tradicionais:

Ao contrário das leis científicas, em que o ver faculta o prever - preceito sintetizado pela fórmula 'assim tem sido, assim será', os efeitos estão invariavelmente ligados à preservação, deliberada ou involuntária, de determinadas condições de efetuação. Efeitos são contingências repetidas ou reforçadas, e não legalidades universais às quais estejamos, sem escapatória, sujeitados (RODRIGUES, 2005b, p. 84).

Encaminhar a análise a partir dos efeitos impõe passar do registro da causalidade para o registro da produção dos saberes e práticas, que se engendram em um processo constituído em diferentes campos de força, campos que se cruzam e se afetam, e que são demarcados por relações de poder (MACHADO, A., 2007). Implica sair do plano das concepções prévias e das predisposições, para pensar o que se efetua, o que se põe em funcionamento e com o que se agencia. O próprio objeto de estudo se constitui nesse campo de forças.

Questionam-se as concepções totalizadoras, que se revestem de naturalidade e de verdade universal, e que têm no saber científico a única possibilidade de compreender a verdadeira essência do mundo. Propõe-se, para além dos consensos e das representações hegemônicas, privilegiar o entre, pôr em relação. Esta ênfase na relação visa desconstruir as unidades, as formas acabadas, fragilizando o que está posto e configurando novos modos e intensidades, que passam ao lado, descosturando os contornos. Privilegiar o entre é afirmar a vida como processo, entender que há múltiplas possibilidades num campo de acontecimentos que extrapola a existência de sujeitos e objetos como coisa-em-si.

Cabe desconstruir o lugar do sábio/cientista visto como representante legítimo, para produzir o pesquisador implicado, aquele cujo projeto político inclui transformar a si e a seu espaço social, pela via coletiva. E apostar no cotidiano como campo de produção e de 
problematização, investindo nos efeitos das práticas e assumindo que a própria investigação produz efeitos, inclusive em si mesma.

Autogestão, analisador, implicação e transversalidade - há um conjunto de conceitos e instrumentos (conceitos-ferramenta) criados e envolvidos para análise e emergência das instituições atravessadas no processo.

\subsection{Algumas ferramentas para transformar e conhecer}

A autogestão é um conceito essencial para o movimento institucionalista, que nela concebe sua força motriz. Refere-se à produção de grupos sujeitos, protagonistas de suas ações, que interferem de forma ativa tanto nos produtos que criam como no processo através do qual eles mesmos são produzidos, apropriando-se dos saberes/práticas em questão, num exercício de permanente reflexão sobre as condições de efetuação de suas ações, em seus limites e possibilidades (ROCHA, M., 2006a).

A construção da autogestão é como percorrer trilhas em uma colocação ${ }^{12}$; não é um caminho simples e linear, pois funcionamos em quase todos os espaços sob a heterogestão, geridos por outrem, com relações de poder bem demarcadas e vivenciadas como fato natural da vida cotidiana. Coletivizar ações implica criar espaços onde os diretamente envolvidos possam apropriar-se de todo o material produzido. Isso é mais do que aderir ao empreendimento de outros ou participar da execução de tarefas. É, como diz Rocha, M. (2007), um movimento construído por cada um e por todos, em sua dimensão históricopolítico-desejante, afirmando outros possíveis.

Um projeto autogestionário está necessariamente associado à construção/utilização de analisadores e à análise das implicações. O analisador, produto de uma situação que age sobre ela, é o que permite revelar a estrutura da instituição, provocá-la, obrigá-la a falar (LOURAU, 2004c, p. 132). Quer seja um dispositivo, pessoa, prática, fenômeno ou acontecimento, manifesta a não conformidade com o instituído, indicando como os acontecimentos aparentemente secundários, os desvios, as crises, revelam as forças sociais não "representadas" ou que não se reconhecem nas representações que as instituições produzem e garantem.

É então revelador e ao mesmo tempo catalizador do não dito, do "recalque político", do impensado, da ordem estabelecida, geralmente coercitiva e arbitrária, e deve dissolver o

\footnotetext{
${ }^{12}$ Colocação é a denominação dada ao modo como se distribui o espaço no seringal.
} 
que há de rígido e institucionalizado, inclusive no processo analítico/interventivo e nos seus analistas/interventores. Assim fazendo, pode modificar as relações de força constitutivas das formas da representação instituída, liquefazendo a cena natural de um cotidiano estratificado, aparentemente estático.

$\mathrm{O}$ analisador coloca em xeque a própria pesquisa-intervenção, questionando a centralização do pesquisador/intérprete e o próprio "ato de interpretar", de fazer valer algo que "fale por todos" (AGUIAR; ROCHA, 2007, p. 655).

A implicação refere-se ao grau de envolvimento do analista para com o objeto estudado, e vai de encontro à famosa neutralidade herdada do cientificismo positivista e suas pretensões de objetividade. Uma nova concepção do papel do intelectual decorre da ênfase depositada neste conceito.

Conforme Lourau (1993, p. 16), “é a relação que o pesquisador mantém com seu objeto, o prático com seu campo, o homem com sua vida”. Ele acrescenta que o escândalo da Análise Institucional talvez esteja nesta proposição, posto que quase todo saber científico baseia-se na noção de não implicação, de um observador externo e distanciado de seu objeto de estudo.

O autor considera que a análise da implicação constitui uma superação tanto da sociologia positivista quanto da branda crítica fenomenológica. E vai além:

\footnotetext{
Se o intelectual "comprometido" (Sartre) se define por sua ligação voluntária com uma causa, uma tese, uma doutrina; e se o intelectual "orgânico" (Gramsci) se define objetivamente por sua adesão pública a uma organização política que lhe possibilite, real ou imaginariamente, participar de um empreendimento histórico cuja concepção ultrapassa seu intelecto individual, o intelectual "implicado" se define pela vontade subjetiva de analisar até o limite as implicações de seus pertencimentos e referências institucionais, bem como pelo reconhecimento do caráter objetivo deste conjunto de determinações (LOURAU, 2004c, p. 147).
}

A implicação focaliza o lugar que cada sujeito ocupa nos grupos, na comunidade, na sociedade, e a forma como estes são atravessados pelas relações sociais. Estar implicado é mais do que envolver-se ou participar, é admitir a interpenetração, a interprodução: admitir que somos produzidos, objetivados, tanto quanto protagonizamos a produção. Assumir que pesquisador e pesquisado, objeto e objetivação, pesquisa e intervenção se constituem em processo, sem hierarquias ou determinações de um sobre o outro, e que ao transformar, também se transformam.

A análise das implicações qualifica as relações sociais como elementos que fazem parte da história e dos processos de institucionalização, marcados por tensões, movimentos e 
incertezas. E remete o pesquisador praticante a investir em modos de intervenção que priorizem a elucidação das determinações transversais.

Acopla-se nesta imbricação a transversalidade. Criado por Guattari na formulação teórica da psicoterapia institucional, relaciona-se à produção de outros modos de ser, afetar/afetar-se e fazer, pela superação do plano cartesiano, e pela potencialização de novos agenciamentos, de alternativas ao desejo (GUATTARI, 1987). Propõe-se como possibilidade de ampliação das comunicações com vistas à superação dos impasses da verticalidade relações sociais institucionalizadas, hierarquizadas - e da análise da horizontalidade relações imediatas, informais nos diferentes estratos - que atravessam os diversos modos de composição do socius.

$\mathrm{Na}$ perspectiva dos socioanalistas, trata-se do atravessamento de indivíduos, grupos, organizações e estabelecimentos pelo conjunto de funções e/ou instituições que produzem e reproduzem as relações sociais dominantes/instituídas (LOURAU, 2004c). Somos atravessados por instituições, e este entrecruzamento de pertencimentos e referências sociais, políticas, econômicas, ideológicas, está posto em circulação nas diferentes composições que são traçadas no cotidiano dos espaços vividos.

Com os conceitos de implicação e transversalidade, o trabalho de pesquisa-intervenção assume que todo conhecimento se produz em um campo diversificado, determinado por relações de força, e se processa no devir, ou seja, envolve movimento e transformação da realidade, e abertura para ser atravessado, para potencializar novos encontros. Um encontro pode ser limitado, dentro de linhas duras em que já se espera o que decorrerá, ou, se o índice de transversalidade aumenta, pode possibilitar que outros sentidos surjam.

\subsection{Esquizoanálise}

Na busca de compreender e pensar os processos que se movimentam nos cotidianos escolares, que os produzem e são por eles produzidos, tem-se o apoio de algumas ferramentas conceituais propostas pela Esquizoanálise. Não se pretende uma revisão exaustiva dos autores convocados, mas, simplesmente, pinçar de suas teorias algumas ferramentas que possibilitem não apenas a descrição do que é feito, mas a compreensão do percurso que vem sendo produzido nas práticas escolares, a partir de seus efeitos.

A Esquizoanálise, como um plano de conhecimento amplo e ubíquo, fruto do encontro de Giles Deleuze e Felix Guattari, emergiu em torno dos anos 1970 como herdeira das lutas libertárias de maio de 68, e vem influenciando diversos pesquisadores no Brasil e no mundo. 
Introduz, através da análise micropolítica das relações desejantes e de poder, uma leitura das relações clínicas, sociais e institucionais, que se desdobra em novas relações e uma nova conceituação sobre o inconsciente, o desejo, a subjetividade, focalizando a relação entre capitalismo e esquizofrenia, título de sua obra principal, que é dividida em dois tomos: "o antiédipo" e "mil platôs".

Como crítica ao pensamento da representação e às filosofias da identidade, a Esquizoanálise propõe uma radical afirmação da vida e pela vida, um desprezo pelas verdades gerais e absolutas, e uma obstinada procura do novo, do insólito, do diferente. Mas não se limita à crítica: intenta intervir no campo político e social, para que o processo de produção desejante tenha seu curso, sem centro, sem hierarquias, sem chefes (TADEU, 2007).

A ciência dos paradigmas dominantes, através da interpretação das regularidades, procura explicar o mundo ordenado e quadriculado. A Esquizoanálise desvela-se num caçar linhas de fuga, privilegiando a potência inventiva que não está nem no sujeito, nem no objeto, nem nas idéias, nem nas coisas, mas sim no entre - espaço de invenção/lugar da produção.

Uma fábrica de conceitos: quer agenciar, maquinar, potencializar a potência do acontecimento, mover territórios, desestratificar, compor forças... E um novo paradigma: o ético-estético-político, que muda radicalmente o eixo de análise, passando a agregar outros elementos. Muylaert (2006) assim sintetiza: o processo de produção de saberes é relacional, atravessado por valores vitais - ético; que sustentam a criação de estilos de vida - estético; produzindo modos de existência atravessados por vetores de enunciação coletivos - político.

Há um conjunto de ferramentas conceituais que imprimem a possibilidade de uma nova compreensão dos fenômenos psíquicos, sociais, históricos e políticos, provendo também um conjunto de dispositivos de intervenção. Os conceitos podem ser considerados "caixa de ferramentas", armas, estratégias de análise, ferramentas com ordenadas intensivas, acontecimentos. Não são fórmulas, mas formulações existenciais. Podem ser abordados desse modo, pois conforme Muylaert (2006, p. 110),

operam a partir da mesma qualidade de força da Arte: estados intensivos, produção de multiplicidade, transbordamento de fronteiras. Abrem-se para a expansão e multiplicação dos sentidos. Não enclausuram o pensamento e os fazeres em um único modo - certo, verdadeiro, científico, totalizante, geral.

Provar, com-provar, reproduzir, generalizar são critérios da pesquisa científica positivista. Na esquizoanálise, importa saber se funciona e como funciona; o afetar e ser afetado; o traduzir e propiciar acontecimentos. Uma Filosofia da Diferença radicalmente potente para desbancar a primazia do idêntico; uma filosofia da imanência, que se opõe a 
qualquer transcendente; uma filosofia das multiplicidades, pois conforme Deleuze e Guattari (1992, p. 82) o plano de imanência é povoado por multiplicidades, "um pouco como as tribos povoando o deserto sem que ele deixe de ser um deserto". É lá que alguma coisa passa.

Para Benedetti (2007, p. 35), esta obra filosófica possibilita uma infinidade de entradas para fazer trepidar o pensamento, muitas formas e passagens para dela entrar e sair, e dependendo de como e por onde se acessa e por quais problemas se é impulsionado, pode-se enfatizar um ou outro conceito, "sabendo-se que são componentes de um mesmo construtivismo erigido como estilo de vida e pensamento, simultaneamente". Interessa aqui destacar alguns de seus conceitos, a fim de potencializar discussões sobre o cotidiano escolar. Como salienta Silvio Gallo (2008), embora Deleuze não tenha se dedicado a problemas relativos à Educação, era um educador, e a fecundidade de seu pensamento pode nos permitir “pensar a Educação", ou seja, propor exercícios de pensamento que potencializem pensar a educação como acontecimento, desalojando falsas certezas.

Um primeiro aspecto a considerar é que, nesta proposição, o desejo não é definido como falta ou como negatividade, mas como produção. O desejo era caracterizado, principalmente pela Psicanálise, como força impulsionadora individual que conduz os homens para a ação de buscar algo que os completará, algo que falta. Ao contrário, a Esquizoanálise pensa o desejo como produção, como fluxo, como potência que se atualiza nas relações, nos encontros com o mundo, produzindo realidades. O desejo resgata a força ativa dos corpos e a coloca na vida. E como força motriz, não é propriedade de um sujeito, ou de um objeto, muito menos é proveniente da falta. É produção não intencional, que ganha liga nos agenciamentos e cuja única "meta" é passar.

O desejo remete para uma nova forma de pensar o inconsciente: o inconsciente é maquínico, é usina, uma matéria virtual ativada pelo desejo-força que, a partir do agenciamento, dá forma e produz o real. É matéria acontecendo no momento mesmo em que acontece, o acontecimento trazendo seu sentido, sua compreensão, não havendo um "isso", um lugar privilegiado separado do que acontece e do seu significado. O desejo é essa força afirmadora que atravessa todos os mundos, todos os corpos, podendo-se falar então, em uma produção social como produção desejante, que não se centra numa subjetividade individual, e sim coletiva (DELEUZE; GUATTARI, 1976).

Convém situar que o adjetivo maquínico não se propõe a descrever a realidade tendo por modelo a máquina, não se refere a maquinismo ou mecânica. Com este conceito Deleuze e Guattari (1976), privilegiam a ideia de funcionamento, de produção, de interação. Toda 
máquina é uma rede complexa de partes em interação, em que cada parte é ela mesma uma máquina, que se conecta a outras máquinas e produz ações.

A noção de máquina é importante porque não se caracteriza pelo que é, mas pelo que faz, pelos efeitos que produz. Como salienta Guattari (1992), as máquinas referem-se a uma organização de fluxos, a uma engrenagem de produção regida por forças que circulam e afetam o mundo. São mecanismos produtores e reprodutores, e constituem acoplamentos heterogêneos que agenciam. Máquina, nessa acepção, consiste em uma tentativa de abandonar o vocabulário que torna possível remeter ao sujeito como agência, para substituí-lo por uma linguagem completamente nova. A linguagem idealista de almas e sujeitos é substituída por uma materialista, ligada às práticas, aos acoplamentos heterogêneos que produzem efeitos (OLIVEIRA, R., 2005).

Uma ideia a destacar nesta noção é que, como sintetiza Maia (2006), o todo (suposto em um conceito, ferramenta ou máquina) jamais totaliza, é apenas mais uma parte que totaliza umas tantas partes, sem deixar ela mesma de funcionar como parte de outras tantas partes. A este funcionamento por fluxos e cortes de fluxos, uma conexão da qual já não se diz mais que é, mas que se articula em um " $e$ ", conectivo conectante, Deleuze e Guattari (1976) denominam como agenciamento maquínico.

O fluido interessante é que o agenciamento maquínico não funciona reduzido a uma causalidade linear, em que se parte de um centro e evolui naturalmente, dividindo-se e subdividindo. Ao contrário, como o todo jamais se totaliza, sendo parte de tantas outras partes, atravessadas por fluxos e cortes de fluxos, o modelo proposto para o agenciamento é o de rizoma (DELEUZE; GUATTARI, 1995a).

Como esclarece Silvio Gallo (2008, p. 76), a metáfora do rizoma subverte a ordem da metáfora arbórea, que tradicionalmente caracteriza a estrutura hierárquica e fragmentária do conhecimento. Ao propor regular o fluxo de informações pelos caminhos internos da árvore do conhecimento, este paradigma fechado, paralisa. Os rizomas, sempre abertos, fazem proliferar.

Os rizomas procedem por alianças, qualquer parte pode conectar-se a outra parte, sem pontos de chegada ou de partida, possibilitando pelos princípios de heterogeneidade, posto que qualquer conexão é possível, e de multiplicidade, pois envolve a contínua ligação e religação com outros elementos em um fluxo constante. E como fluxo, os rizomas colocam-se na horizontalidade, multiplicando as conexões que deles se originam, podendo, portanto, ser mapeados, cartografados, e mesmo acessados de vários pontos que remetem a outros tantos. Não há também qualquer processo de hierarquização. Embora territorializados e organizados, 
estão continuamente atravessados por linhas de fuga que apontam para novas direções (DELEUZE; GUATTARI, 1995a).

Essas contínuas conexões entre elementos múltiplos e mutáveis, em diferentes formas e intensidades, e que se ramificam constantemente em outros elementos, estando eles próprios em constante metamorfose, configuram a realidade em devir ((DELEUZE; GUATTARI, 1997a)). Como dizem Parpinelli e Souza (2005), a realidade, constituída de maneira rizomática, se configura no entrelace de devires, imagens, objetos, afetos, etc. É no encontro de múltiplos elementos que se desenha uma cena da realidade. $\mathrm{O}$ devir converge com o conceito de multiplicidade, sendo para Deleuze e Guattari (1997, p. 33) "uma só e mesma coisa".

Para Tadeu (2007), pela noção de multiplicidade, Deleuze e Guattari intentam sublinhar os processos de movimento e de devir, em vez das noções estáticas de essência e de um ser "já e para sempre constituído". Isto permite pensar a diversidade e variedade do mundo sem recorrer às noções de uno e de múltiplo. Um mundo constituído de multiplicidades é um mundo em movimento contínuo, um mundo de criações.

Neste movimento também se podem situar as subjetividades. A subjetividade é uma noção complexa, concebida como um sistema aberto, constituído de múltiplas e diferentes forças, que não se reduz ao individual ou ao intragrupal.

Guattari (2006) considera a subjetividade pelo ângulo de sua produção e não como uma substância essencial do sujeito. Ou seja, falar em subjetividade é uma forma de tentar escapar à ideia tradicional de sujeito da consciência. O sujeito é geralmente compreendido como uma forma de apreensão pré-reflexiva, como unificador de estados da consciência. No entanto, como afirma Guattari (2006, p. 17), o sujeito não é evidente, "não basta pensar para ser, como proclamava Descartes. [...] o sujeito advém no momento em que o pensamento se obstina em apreender a si mesmo e se põe girar como um pião enlouquecido sem enganchar em nada dos Territórios reais da existência". Por isso, considera mais apropriado falar em componentes de subjetivação, conceito que pode ser entendido como um agregado de inúmeras máquinas que compõem a realidade. A subjetividade é tecida no contexto dos múltiplos cruzamentos destes componentes e pela rede de micropoderes que lhe atravessa, numa articulação de aspectos psíquicos com todas as forças dinâmicas que compõem a realidade, de modo rizomático.

Conforme Guattari (2006), com o capitalismo e a ideologia liberal produziu-se uma nova organização dos indivíduos no mundo do trabalho, com novas formas de compreender o mundo, de travar relações entre si e de se perceber individualmente, gerando o que foi 
denominado como modo de subjetivação capitalístico. Mas os modos de subjetivação, ou seja, os diferentes modos de produção de subjetividades, não estão restritos às sociedades capitalistas. Um modo de subjetivação está sempre ligado à busca de uma estabilização da subjetividade em torno de certo tipo de relação, que é diferente nos vários momentos históricos, e se estende à produção de um determinado tipo de configuração do campo social. Portanto, a subjetividade é fruto de um agenciamento social múltiplo, assumida e vivida em suas existências particulares, e está em circulação nos conjuntos sociais de diferentes tamanhos. Não pode ser encarada como uma coisa em si, uma essência imutável, pois os modos de existência - ou de subjetivação - são históricos e mantêm estreitas relações com uma conjuntura especificamente considerada. A subjetividade é a própria trama, e não tem um antes já dado; ela é a composição dos diferentes universos que habitam cada existência e que se alojam sob a forma de sensação, sempre versátil aos novos arranjos.

Catharino (2000, p. 45) observa que ao se considerar os modos de subjetivação, o interesse se volta para o processo, que é concebido como permanentemente recomeçado. Portanto,

[...] se falamos em subjetividades, o fazemos sempre referidos a um tipo de produção, coletivamente engendrada no tecido social. Isso não quer dizer que devemos ignorar a existência de uma individuação das subjetividades afinal, não se trata de negar a existência do sujeito, mas de afirmá-lo como uma forma provisória, prismática e avessa à idéia de totalização.

Desse modo, as análises voltam-se para os modos de subjetivação, ou seja, o processo e as maneiras de produção através das quais elas se plasmam e se efetivam no campo social. Há um deslocamento do produto - a idéia de sujeito - para o processo - os modos de subjetivação. Não existe sujeito significante, não há lugar assinalável por uma transcendência qualquer, existem apenas processos em meio às multiplicidades (GUATTARI; ROLNIK, 1986).

A subjetividade não é passível de uma totalização ou de centralização no indivíduo.

Uma coisa é a individuação do corpo. Os indivíduos são o resultado de uma produção em massa. O indivíduo é serializado, registrado, modelado. Outra é a multiplicidade de agenciamentos da subjetivação: a subjetividade é essencialmente fabricada e modelada no registro social (Ibidem, p. 31)

$\mathrm{Na}$ era das revoluções informáticas, do surgimento das biotecnologias, da criação acelerada, de novos materiais de uma maquinização cada vez mais refinada do tempo, novas modalidades de subjetivação emergem continuamente. A realidade do mundo contemporâneo 
impõe a circulação dos indivíduos por diferentes dispositivos e circuitos de produção de subjetividades engendradas entre outras verdades e certezas, pondo em questão aquelas às quais pretensamente estes vinham construindo. Consequentemente, as possibilidades subjetivas multiplicam-se. Mas Guattari (2006; 1992) alerta para o processo de produção de subjetividades homogeneizadas, chamando atenção para lutarmos contra os modos de subjetivação normalizantes. Propõe que se desenvolvam processos de singularização, estabelecendo guerra às máquinas de captura do Estado e do capitalismo mundial integrado, que pretendem transformar tudo em mercadoria.

Pode-se falar em processos de subjetivação, segundo Deleuze (1992), quando se consideram os diferentes modos pelos quais os indivíduos, grupos ou coletividades se constituem como sujeitos; mas tais processos só valem quando, ao acontecer, escapam tanto aos saberes constituídos como aos poderes dominantes, mesmo se engendram novos saberes ou novos poderes. Portanto, para engendrar o novo, Deleuze sugere que devemos suscitar acontecimentos, mesmo pequenos, que escapem ao controle, potencializando atos criativos.

Para a Esquizoanálise, a subjetividade se constitui e se autorreconstitui por fluxos de agenciamentos com os quais ela está constantemente se conectando e reconectando. E o desejo é a força motriz dessa máquina subjetiva, que mantém o fluxo do devir, que impulsiona o ser humano a produzir e se conectar com diversas máquinas processuais. Produzir, criar ligações, é a emergência de desejos instituintes.

$\mathrm{O}$ agenciamento é um conceito-ferramenta fundamental nessa teoria, e funciona conforme o modelo rizomático, num ir e vir de múltiplas conexões. $\mathrm{O}$ agenciamento, pura virtualidade, comporta dois segmentos: um de conteúdo e outro de expressão. $\mathrm{O}$ de conteúdo é o agenciamento maquínico, mistura dos corpos reagindo uns sobre os outros, misturando-se, transmitindo afectos. O segmento de expressão refere-se ao que se produz entre os corpos que se encontram, provocando transformações incorpóreas. Há uma mistura de atos e enunciados que, assim como o agenciamento maquínico, produzem uma multiplicidade rizomática de encontros, de modo tal que não pode ser reduzido a nenhum sujeito de expressão e, portanto, deve ser entendido como um agenciamento coletivo de enunciação (DELEUZE; PARNET, 2004; DELEUZE; GUATTARI, 2003).

Estes dois lados do agenciamento compõem um primeiro eixo, horizontal, ao que se acrescenta um outro eixo, vertical, no qual o agenciamento se estabiliza, por um lado, em territorializações e reterritorializações e, por outro, é impelido à desestabilização por linhas de fuga, nas desterritorializações (DELEUZE; GUATTARI, 1995b, p.29). 
Maia (2006), discorrendo sobre territórios e territorializações, diz que é próprio do desejo agenciar, conectar-se, construir um plano no qual concretize sua potência, constituindo um território de atuação. Postulando que o desejo "produz e produz real", salienta que Deleuze e Guattari vão utilizar o conceito de território como aquilo que é decorrente do agenciamento do desejo. E se o desejo é móvel, está em constante devir, torna-se mais interessante falar em territorialização. Território, nesta abordagem, não é um lugar, mas uma ação: "toda forma, todo agenciamento, toda expressão, toda função para um conteúdo qualquer, seja material ou não, constitui uma territorialidade. Não é uma apropriação de um meio dado por um vivente dado, mas uma conexão de máquinas que capta, delimita e codifica o fluxo do desejo" (MAIA, 2006, p. 58).

Como toda ação, há um dinamismo presente no território, constituindo movimentos de desterritorialização e reterritorialização. Muito resumidamente, pode-se dizer que a desterritorializaçao é o próprio princípio da criação. Esse movimento equivale a ultrapassar um limiar para além do qual não há mais outra coisa senão zonas de intensidades. Mas se, por um lado, constitui o motor da criação, anunciando a desestabilização das formas, por outro, pode se transformar, também, em linha de abolição ou pura catástrofe. A reterritorialização é todo ato de captura, em que "o desejo é moldado, formatado em padrões, linhas duras que tentam prendê-lo no estabelecido e pulverizar toda e qualquer força revolucionária que lhe é própria" (MAIA, 2006, p. 60).

O território é múltiplo, é uma heterogênese, e por isso tem múltiplos componentes que não estão equilibrados, mas sim constituídos em relações de forças em tensão constante, de linhas de força que se atravessam no plano em devir. Sintetizando, pode-se dizer que em todo território coexistem três tipos de linhas: linhas duras, linhas moleculares ou flexíveis, e linhas de fuga.

As linhas que correspondem a uma segmentaridade dura referem-se aos papeis modelados, aos segmentos bem determinados, em todas as direções, que enquadram os indivíduos em todos os sentidos como "pacotes de linhas segmentarizadas" (DELEUZE; PARNET, 2004, p. 145). São linhas molares que implicam dispositivos de poder, cada um fixando o código e o território do segmento correspondente, e envolvem um plano de organização ou de desenvolvimento que diz respeito, simultaneamente, às formas e seu desenvolvimento, aos sujeitos e à sua formação.

Com as linhas duras seguem linhas moleculares, bem mais flexíveis, que nos atravessam não apenas como indivíduos, mas como sociedade e grupos. De acordo com Deleuze, é sob essa segunda espécie de linhas, de fluxos moleculares, que se passam devires, 
microdevires. Há ainda uma terceira espécie de linhas, que nos conduzem através dos segmentos, mas também através dos nossos limiares, numa direção não preexistente ou previsível, denominadas linhas de fuga. Não é demais salientar que todo território comporta linhas de fuga, nem sempre facilmente visíveis, que nos permitem sair dele. Para todo movimento de territorialização, ou seja, toda organização em uma forma, há uma força desorganizadora que o descompõe. "Descobrir ou construir tais linhas de fuga é o que nos permite sair de um território constituído, realizar uma desterritorialização" (MAIA, 2006, p. 59).

As três linhas são imanentes, tomadas umas nas outras, coexistem sempre, uma pressupondo a outra, sendo necessário um trabalho que foi denominado pelos autores como cartografia para o estudo dessas linhas. E, como diz Carvalho (2008) tudo é político, mas toda política é ao mesmo tempo macro e micropolítica. O plano macropolítico é o plano visível das formas e normas vigentes, enquanto o micropolítico é o plano invisível da produção das diferenças. A autora lembra que, para Deleuze e Guattari, não há oposição entre molarmolecular e macro-micro. O molecular como processo, pode emergir no macro e o molar pode se estabelecer no micro. Não há lógica de contradição entre estes níveis e linhas, tudo está em jogo no cotidiano. O que pode funcionar em nível molar, de modo emancipador, pode, em nível molecular, ser reacionário ou microfascista. Os problemas se colocam sempre e, ao mesmo tempo, nos dois níveis.

Importa no cotidiano escolar cartografar as linhas de um dispositivo, entrando nelas e se deixando atravessar por elas. Cartografar é acompanhar processos, é investigar um processo de produção de subjetividade e, portanto, estudar um território existencial.

O encontro com a esquizoanálise impulsiona a pensar a diferença, a problematizar o corpo maquínico, as subjetividades, colocando em cheque e questionamento as antigas referências de normal e de desvio, superando a causalidade e interessando-se pela transversalidade dos funcionamentos inventivos. Diferença que permite conceber a vida como processo de criar o novo, processos intensivos, de forças, fluxos, movimentos (TADEU, 2007).

\subsection{Desafios à escolarização: por uma escolarização a fios}

Ao se focar a atenção para as práticas pedagógicas, tem-se como eixo pensar o processo de produção da diversidade de situações concretas que se presentificam no cotidiano escolar. Este apresenta-se como campo de experiências e múltiplos agenciamentos, em que 
ora predominam formas mais hegemônicas, ora mais instituintes, que potencializam derivas, rupturas. Trata-se de um campo de forças, isto é, espaço de produção de práticas e de processos de subjetivação, que engendram acontecimentos, sempre em movimento.

Quando se fala em práticas, entende-se que estas são datadas, ou seja, engendradas por condições sociais, históricas e políticas. As práticas constroem sujeitos e objetos, efetuando concepções, paradigmas, princípios, e, dependendo do modo como são estabelecidas e das redes de poder colocadas em jogo, podem legitimar funções e discursos, fazendo prevalecer determinadas verdades, ou potencializar novos fazeres.

Numa comunidade ribeirinha, embora em grande parte do tempo é nos ambientes de terras, florestas e águas que os agenciamentos acontecem e produzem subjetividades, a escola é indubitavelmente o território oficial na produção do cidadão, a porta de legalização de seu roteiro social/profissional/capitalizado. Enquanto representante dos centros de poder hegemônico, imprime como marca os modelos forjados em um ideário capitalista, que funciona numa lógica homogeneizadora e reprodutora de normas, regularidades e universalidades abstratas, sustentando, pelo rigor científico, a ideia de uma sociedade meritocrática. A escola se estabelece como oportunidade, e sustenta em via de mão única, a oportunidade como escola, produzindo personagens, fornecendo como modelo de mundo os padrões de socialização e qualidade reificados.

Esta escola, estratificada em suas territorialidades constituídas, aprisiona os movimentos, desqualifica processos e saberes, imprime sua função de controle e reclusão do diferente. Como enfatiza Rocha, M. (2007), o cotidiano escolar tem sido classicamente constituído para produzir obediência e boas formas, para não ser um espaço/tempo de ousadia. Temos uma escola prescritiva, burocrática, que valoriza prioritariamente o modelo, onde o que escapa deve ser capturado, e que não dá visibilidade às ações, aos rituais, às práticas instituídas sob a hegemonia de uma representação.

Entretanto, sendo campo de múltiplos atravessamentos, deve-se considerar a existência de uma infinidade de tendências, afetos, desejos, com diferentes forças, sendo efetuados no processo de escolarização, e também produzindo efeitos. Para além dos modos de subjetivação hegemônicos, há os que possibilitam outras formas de estar na escola.

No âmbito macropolítico, a organização escolar é reprodutora de orientações normativas, estabelecidas nos centros de decisão política e de controle. Mas no nível micropolítico, o cotidiano escolar, assumido por seus atores concretos, pode confirmar ou reinventar a existência do centro. O desafio está em instalar um campo de análise entre a macro e micropolítica, cartografando as formas de ação que vem contribuindo para a 
naturalização do cotidiano, assim como os modos de organização que potencializam movimentos e derivas. Avaliar um campo de forças, como diz Machado, A. (2003), implica conhecer essas forças que se dão em movimento; implica afetá-las e com isso saber da possibilidade de alterar ou não seu rumo.

Ainda se verifica, neste plano molecular, que poucos agenciamentos têm conduzido a transformações, e a escola tem se constituído em "território sobrecodificado, no qual seu coletivo se agita o tempo todo entre queixas, cansaço, repetições no cumprimento formal das tarefas diárias" (ROCHA, M. 2000, p. 198). Rocha considera que para que novos territórios existenciais sejam agenciados, é preciso abrir caminhos a novas experimentações, colocar-se no lugar do "não saber", perscrutar as brechas. Nas palavras de Deleuze, a produção de mudanças passa pela instalação de dispositivos que abram brechas para o pensamento, para que novas dobras se configurem (DELEUZE, 2006b).

O cotidiano deve ser compreendido como espaço de experimentação e invento, como espaço de afirmação das singularidades, afirmando a diferença como potência. A diferença qualifica a educação como um espaço de práticas capazes de produzir sujeitos singulares, de tensionar o instituído e os mecanismos que instauram cristalizações.

[...] diferença é justamente o que nos arranca de nós mesmos e nos faz devir outro... O que Deleuze e Guattari nos mostram é que a diferença é necessariamente produção de um coletivo, já que ela é o fruto de composições das forças que constituem determinado contexto sociocultural; eles nos mostram ainda que abrir-se para a diferença implica se deixar afetar pelas forças de seu tempo. Uma política que não consiste simplesmente em reconhecer o outro, respeitá-lo, preocupar-se com as consequiências que nossa conduta possa ter sobre ele; mais além, trata-se de assumir as conseqüências de sermos permanentemente atravessados pelo outro, uma política indissociável de uma ética de respeito pela vida (ROLNIK, 1993, p. 255-256).

Pérez (2007) sugere incorporar as noções de acontecimento e heterotopia às práticas acadêmicas, como uma tentativa de subverter a herança platônica de pensar segundo modelos, cópias e semelhanças, substituindo-a por um pensar rizomático, que engendra novas leituras do mundo. O cotidiano escolar é habitado por regras, códigos, leis, mas também pela desordem, pelo caos. É repleto de acontecimentos que como rizomas aparecem, desaparecem, se afastam e se escondem, retornam e voltam a desaparecer.

São as forças potencializadoras do desejo que criam os espaços diferentes - as heterotopias marginais. Vivemos num espaço de relações que definem lugares e engendram processos de subjetivação - modos de vida que se criam e se recriam, numa luta permanente 
que nos arremessa aos limites entre o que estamos deixando de ser e o que estamos nos tornando, entre subjetividades constituídas e processos em devir.

Através do deslocamento realizado por Gallo (2008), pode-se dizer que uma educação menor configura acontecimentos, singularidades que sustentam a diferença e a descentralização. Produzir novos significados e sentidos para a ação escolar é uma ação rebelde que se traduz em práticas instituintes, seja no âmbito da organização curricular e das ações pedagógicas desenvolvidas cotidianamente na sala de aula, seja no âmbito da formação das professoras, ou ainda no âmbito da relação escola-comunidade.

Afirmar esses escapes é, sem dúvida, estar atento às linhas de fuga, que estão no mundo e que, muitas vezes microscópicas ou mesmo invisíveis, estão produzindo/criando outras realidades. Assim, construindo fio a fio, tecem-se caminhos, saberes, derivas, procurando "dar passagem àquilo que deixa de ser a cada momento, ao que não é capturado", ao movimento, à diferença.

\section{Pela via do Cotidiano}

O cotidiano dos estabelecimentos escolares tem ensejado diversos estudos nas últimas décadas (ALVES, 2003; ANDRÉ, 1995; ANDRADE, 1990; AZANHA, 1992; EZPELETA; ROCKWELL, 1986; FERRAÇO, 2008; GALVÃO, 2008; GARCIA, 2003; OLIVEIRA, I., 2008), em diferentes abordagens, e uma renovação de métodos vem alterando as práticas de pesquisa na área.

A psicologia tem sido instigada a contribuir neste debate, tendo, dentre suas contribuições, a busca de referenciais para a leitura da prática educativa como processo social, e a análise e intervenção em uma variedade de situações do cotidiano escolar, como desentendimentos entre professores e alunos, violência, baixo rendimento, repetência e evasão, sob a perspectiva de uma prática educativa transformadora, sintonizada com os saberes e demandas do público a que se destina. Pesquisas na área de Psicologia Escolar e Educacional, em contraposição à tendência hegemônica que se caracterizava por localizar os problemas de aprendizagem na criança, em sua família ou em suas condições de vida, passam a considerar todo o processo de escolarização, e a complexidade das interações envolvidas no processo de ensino-aprendizagem.

O debate acerca da crise dos sistemas educacionais também tem colocado como desafio ao campo educacional brasileiro a busca de novos referenciais teóricos para 
interpretar o universo da escola, tendo, no recurso à investigação etnográfica e nos estudos de caso, uma tentativa de aproximar-se dos fazeres ordinários da escola (FARIA FILHO et al., 2004).

Madeira (2006) considera significativo o andamento da pesquisa educacional nas últimas décadas, superando-se os enfoques literários voltados para fins e objetos, sobrepujando-se os discursos pedagógicos voltados para métodos e técnicas, e ultrapassandose as abordagens psicológicas mais interessadas em comportamentos e atitudes. Para a autora, uma nova visão concentrou-se no cotidiano das organizações educacionais como cenário de práticas exercidas por atores sociais. "Foi a renovação de uma perspectiva etnográfica, valorizando-se mais o cotidiano e o real em sua concretude do que a elaboração de análises nos rigorosos padrões de aparência científica" (MADEIRA, 2006, p. 42).

Marli André, pesquisadora que vem estudando o cotidiano escolar desde a década de 1970, fala da importância dos estudos sobre o cotidiano escolar e da utilização da pesquisa etnográfica como uma forma privilegiada de se compreender os mecanismos que operam no seu dia a dia. Segundo esta autora, este estudo se coloca fundamental para compreender como a escola desempenha seu papel socializador, seja na transmissão dos conteúdos acadêmicos, seja na veiculação das crenças e valores que aparecem nas ações, interações, rotinas e relações sociais que caracterizam o cotidiano da experiência escolar (ANDRÉ, 1989). Voltando-se para as experiências e vivências concretas dos indivíduos e grupos que participam do cotidiano escolar e o constroem, podem-se apontar importantes elementos para a prática pedagógica, e para a compreensão da dinâmica social que nele se expressa.

Sob a ótica das pesquisas nos/dos/com os cotidianos, considera-se interessante pensar os cotidianos como espaçostempos privilegiados de produção da existência, e dos conhecimentos, crenças e valores que a ela dão sentido e direção. Diferenciando-se dos estudos que se baseiam na análise dos discursos ou das políticas educacionais, o estudo do cotidiano busca compreender como se dão as práticas, as relações e situações que ocorrem efetivamente no dia a dia dos estabelecimentos educacionais, e que tecem as redes de saberes e fazeres (OLIVEIRA, I.; ALVES, 2008; ALVES, 2003).

Mas de que cotidiano se fala? O cotidiano é o repetitivo, o conjunto de atividades com aparências modestas. Abrange as coisas, o dia-a-dia das pessoas. É o insignificante, pelo menos aparentemente; ocupa e preocupa e, no entanto, não tem necessidade de ser dito. Emerge em um campo de forças, que se move continuamente, campo de intensificação da vida, de experimentação do pensamento (AGUIAR; ROCHA, 2007, p. 654). 
É também o contexto de nossas invenções, contradições e superações. São movimentos banais, rotineiros, mas complexos e sempre articulados, que compõem o nível de realidade onde atravessam mudanças e onde se criam as obras humanas. $\mathrm{O}$ fazer cotidiano inclui, de modo inseparável o fazerpensar, a praticateoriapratica, em movimentos que misturam sempre agir, dizer, criar, lembrar, sentir. Qualquer mudança social só se faz efetivamente quando penetra neste nível de realidade (ALVES, 2003).

No cotidiano, tudo se faz múltiplo: nele se reinventa a vida. Remetendo a Certeau (2008), a vida cotidiana é criativa e se reinventa permanentemente, e isto difere significativamente de concepções que veem o cotidiano apenas como repetição e reprodução do instituído, ou de uma "estrutura social abstrata que, além de explicar toda a realidade, a determinaria" (OLIVEIRA, I., 2008, p. 35). Conforme estes pesquisadores praticantes, dos modos historicamente constituídos de fazer e utilizar tanto objetos, como regras e linguagens, vão emergindo novas formas de utilizar a ordem imposta, pois as práticas cotidianas seguem regras próprias, diferentes da produção e do consumo oficiais. "Os cotidianos vão se revelando ou se escondendo, como rizomas aparecendo, desaparecendo, reaparecendo, a desafiar nossa coragem de ousar” (FERRAÇO, 2003, p.163).

Na expressão de Rocha e Uziel (2008, p. 533), um "laboratório de experiências onde os (des)arranjos se fazem, e as estratégias de enfrentamento do imprevisível se constituem nas circunstancias e condições que variam. É superfície de deslizamentos em que repetimos o esperado, o já inscrito em nossas agendas e que lutamos para cumprir, mas também é tecido denso que entre tramas e dramas intensifica existências e dá o que pensar”.

Oliveira, I. (2008) salienta que por muito tempo os estudos generalistas abdicaram da pluralidade e da diversidade, dentre outras especificidades, das realidades concretas e de seus processos reais de construção. Alves (2003) reforça esta idéia, afirmando que há modos de fazer e de criar conhecimentos nos cotidianos, diferentes daquele aprendido na modernidade, especialmente, e não só, com a ciência. O que se aprendeu sobre "o pensar e fazer ciência" foi criado em um movimento que precisou superar e mesmo negar os conhecimentos cotidianos e os modos como eram/são criados. Todavia, é na vida de todo dia que o ser humano se faz humano e, para compreendê-lo, faz-se necessário debruçar-se sobre a trivialidade da vida cotidiana. É preciso estar atento a tudo o que nela se passa, se acredita, se repete, se cria e se inova, ou não.

Ferraço (2008), neste mesmo movimento, argumenta que professores e alunos cotidianamente produzem artimanhas de reapropriação dos espaços e tempos escolares, criam saídas originais para enfrentar os problemas vividos, valendo-se de pequenas fugas das salas 
de aula para suportar as pressões dos papeis institucionais que lhes são atribuídos, entre outras coisas. Não há como entender e trabalhar com lógicas produzidas pelos alunos e seus professores, sujeitos contemporâneos, a partir, unicamente, da lógica cartesiana. "Há que produzir novas linguagens, novas relações espaçotemporais, novas formas de interação e pesquisa com os que, de fato, inventam o cotidiano a cada dia” (FERRAÇO, 2008, p.106).

Preocupar-se com os movimentos, entender os acontecimentos. Estudar práticas cotidianas, procurando nelas não as marcas da estrutura social que as iguala e padroniza, mas, sobretudo, "os traços de uma lógica de produção de ações de sujeitos reais, atores e autores de suas vidas, irredutível à lógica estrutural, porque plural e diferenciada". Esta é, conforme Oliveira, I. uma ação fundamental (OLIVEIRA, I., 2008, p. 58). E acrescenta: “Os cotidianos das escolas, no qual os sujeitos tecem suas redes de fazeres, onde vivem, agem, sentem, sofrem, amam os seus 'praticantes ordinários' só existem quando cessa a busca da visibilidade 'panóptica' de uma escola abstrata, vista do alto" (OLIVEIRA, I., p.59).

Mas Alves alerta sobre a necessidade de reconhecer que isso não é fácil, pois estamos presos a uma lógica da observação e classificação bastante estruturadas em nosso modo de fazer ciência, e que levou à grande dificuldade de se aceitar o múltiplo. Entende, assim, que só é possível analisar e começar a entender o cotidiano escolar através de um grande mergulho na realidade cotidiana da escola, com todos os sentidos, e não somente pelo olhar distante e neutro, aprendido e exaltado (ver para crer) com essas virtualidades da modernidade.

O mergulho no cotidiano possibilita conhecer a riqueza, multiplicidade e complexidade que estão nas escolas, entre alunos, professores, pais, técnicos e gestores, entre práticas e articulações, para buscar intervir de modo mais consoante com as especificidades locais e individuais. Permite aproximar-se de cenas miúdas do dia a dia que constituem o contexto onde eclodem os conflitos, posto que as diversas culturas - tanto as legitimadas quanto as negadas - fazem-se presentes (ALVES, 2008), penetrando de modo peculiar nos espaços de poder. Favorece a compreensão de elementos da dimensão subjetiva que atravessa o processo educativo, e fornece indícios para que se avaliem os componentes objetivos do ambiente escolar: propostas, material, espaço e regras. Oferece, enfim, inúmeras pistas sobre os modos como, na prática social, são produzidas e encontradas soluções locais.

O cotidiano é tecido por caminhos próprios, mas mantém múltiplas relações com o nível macro. Para Paim (2003), o espaço do cotidiano escolar carrega como ponto constitutivo o entrelaçamento entre micro e macro realidades, possibilitando o diálogo entre diferentes e diversas subjetividades. 
Conforme Martins, João (2003), ao se tomar o cotidiano escolar como campo de investigação/intervenção, tem-se acesso às várias dimensões da instituição, à sua história documentada e não documentada, citando Ezpeleta e Rockwell, o dito e o não dito na perspectiva da análise institucional.

Configura-se, assim, como o campo dos múltiplos atravessamentos, em luta permanente entre os processos instituídos, que aprisionam os movimentos, e as forças de invenção. Nele se circunscrevem variações produzidas nos diferentes momentos em que foram repetidas, ora afirmando as representações existentes, que prometem equilíbrio, neutralidade e certo poder de contribuir para a manutenção do que está, ora desmontando hábitos e lugares cristalizados, potencializando a emergência de outras pontes de singularização.

O cotidiano é isso, e é também o receptáculo da passividade, da desesperança, do enfadonho, da falta de perspectiva, enfim, da miséria do dia a dia nos confins da Amazônia. Mas é, sobretudo, o que contém a possibilidade de mudança da vida, pois possui uma dimensão de riqueza que não se restringe ao material ou econômico concentrado nas mãos de poucos, mas ao virtual que produz a vida e que se refere às relações sociais entre as pessoas, os grupos, a coletividade (OLIVEIRA, J., 2000).

Os aspectos da vida cotidiana interessam, portanto, aos que consideram que essa instância de repetitividade e de atos banais é também espaço de luta e de possibilidades transformadoras. É pensar que práticas podem ser reengendradas. André (1989) assinala que a escola, sendo constitutiva da práxis social, não foge ao estabelecido por um modelo de sociedade que cria suas instituições para legitimá-la, refletindo as marcas de um sistema que mercantiliza as relações, pessoas e práticas. Entretanto, aponta que do mesmo modo que a realidade social se configura contraditória, expressando uma correlação de forças por vezes também antagônicas, a escola é um campo propício para a emergência das contradições socioculturais e econômicas que marcam nossa sociedade. Convivem lado a lado no cotidiano escolar, movimentos em favor da consolidação da ideologia dominante e toda uma dinâmica de resistência e contraposição que se move no sentido de questionar a ordem vigente, e de concretizar uma participação efetiva, mesmo que isto se esconda sob as mais diversas aparências.

Galdini e Aguiar (2003, p. 88) salientam que a escola é um espaço institucional e de mediação social que "revela, nas suas formas de ser, relações sociais e políticas, conteúdos de classe, valores, ideologia". Não é um campo neutro, pois não há prática neutra, desvinculada do contexto social, político e econômico em que está inserida; ao contrário, reproduz e 
legitima relações hegemônicas. Brancaleoni (2005) reforça esta ideia, considerando a escola como um espaço sóciocultural, onde diferentes forças se desvelam. Mas ao mesmo tempo em que reproduz e legitima a hegemonia, apresenta momentos de resistência e mesmo construção de uma contra-hegemonia. Se por um lado há mecanismos de dominação e conservação, por outro procedem à transformação.

Para Coimbra e Leitão (2003), nas instituições que têm a norma como referência e a lógica capitalista como modo de subjetivação, há possibilidades de produzir rupturas, derivas, outras construções e conexões, outras subjetividades que não as hegemônicas. São linhas de fuga, forças instituintes querendo agir. Há um movimento que decorre seja pela insatisfação dos agentes presentes neste espaço com as formas instituídas de organização, seja pelo movimento que se produz na dinâmica do cotidiano escolar. O que acontece na escola é resultado de uma ampla rede de relações entre os agentes ali envolvidos. Na expressão de André (1995), são pessoas em relação, produtores e produtos de encontros, desencontros e possibilidades, como uma cadeia de anéis que se ligam de várias maneiras, e articulam-se de diferentes formas com o todo social mais amplo. Assim sendo, os membros da escola têm a possibilidade de simplesmente reproduzir concepções e práticas, ou de transformá-las.

Imersa em um campo de forças historicamente construído, a prática educativa é atravessada por diversos mecanismos que se fazem presentes nas ações pedagógicas que constituem o cotidiano escolar (FERNANDES; ROZENOWICZ; FERREIRA, 2004). O estudo do cotidiano deve, portanto, envolver um processo de reconstrução dessa prática, para desvelar suas múltiplas dimensões, refazendo seu movimento. Assim, pode auxiliar na produção de dispositivos que acionem novos processos de subjetivação de modo a potencializar a vida das pessoas e seu saber fazer, provocando a desnaturalização das práticas instituídas na dinâmica escolar.

Em se tratando de escolas rurais na Amazônia, interessa à pesquisadora contribuir na investigação de seus modos múltiplos e peculiares. Conhecer os movimentos que lhe atravessam, as práticas que lhe constituem e ali se constituem, é um desafio. Mergulhar no cotidiano escolar pode significar um caminho possível para potencializar linhas de fuga, e o enfrentamento ao projeto histórico de escolarização estabelecido para a educação rural. 


\section{OBJETIVOS}

\section{Objetivo Geral}

Investigar os agenciamentos que se operam na escola na produção de novos modos de relacionamento ser humano-ambiente em uma comunidade ribeirinha amazônica, recentemente incorporada à geografia urbana.

\section{Objetivos Específicos}

1) Constituir uma caracterização da comunidade, abarcando aspectos sociais, históricos e políticos;

2) Caracterizar o estabelecimento escolar, descrevendo cenas do cotidiano, espaço físico, agentes institucionais e clientela;

3) Investigar os atravessamentos presentes nas práticas pedagógicas, buscando identificar formas estratificadas e mecanismos que potencializem novas subjetivações;

4) Investigar as avaliações e expectativas sobre a escola, bem como as estratégias utilizadas na produção de sentidos e significados sobre a relação escola-comunidade; 


\section{METODOLOGIA}

\section{Referenciais metodológicos}

O estudo desenvolvido para fundamentar esta tese partiu das inquietações inerentes à pratica pedagógica desta pesquisadora, tanto na universidade como nas escolas públicas onde se envolveram projetos, objetivando compreender a dinâmica da vida cotidiana em uma comunidade ribeirinha, e o papel desempenhado pela escola nos processos de mudança social, na relação saber acadêmico/saber tradicional. Interessava conhecer a multiplicidade de vozes presentes, as práticas instituídas e as forças em contraposição.

Para responder a estas inquietações, optou-se por um mergulho no cotidiano escolar, aportando no que é local, singular, mas entendendo que micro e macro se articulam, e um processo em particular não se exclui da totalidade maior que o determina. Citando Alves (2008, p.45), "a trajetória de um trabalho no cotidiano precisa ir além do que foi aprendido com as virtualidades da modernidade, na qual o sentido da visão foi exaltado. É preciso executar um mergulho com todos os sentidos no que desejo estudar".

Admite-se, concordando com Azanha (1992), que apenas um fragmento limitado desse real pode se constituir como foco de nossa compreensão. Mas também se deve considerar que não estamos totalmente livres das pretensões/ilusões de que o cientista possa acessar a totalidade da experiência que se destina investigar, que nos faz querer abarcar todas as possibilidades presentes no cotidiano. Isso envolve um contínuo indagar-se, num exercício de reflexão e argumentação.

Considera-se que o cotidiano é fruto da experiência coletiva, os resultados são sempre provisórios, e para sua compreensão é fundamental a contextualização dos fatores, a análise das forças que os produziram e os efeitos das práticas (ROCHA, M., 2006a). O estudo do cotidiano escolar deve envolver "a reconstrução dos processos que se desencadeiam, desvelando suas múltiplas dimensões, refazendo seu movimento, apontando suas contradições, recuperando a força viva que nele está presente" (SATO; SOUZA, 2001, p. 42).

Pelo caráter das opções teórico-metodológicas e dos objetivos intencionados, considerou-se oportuno o uso da abordagem qualitativa. Conforme Minayo (1996) e Bogdan \& Biklen, (1994), a pesquisa qualitativa busca compreender e explicar a dinâmica das relações sociais, trabalhando com a vivência, a experiência, o cotidiano, o universo de significados, motivos e aspirações, questões muito particulares que não podem ser 
quantificadas. Permite que sejam analisados, descritos e interpretados os dados coletados, considerando-se seus efeitos no ambiente social. Possibilita o uso e desenvolvimento de uma variedade de recursos e de técnicas, e uma ampla liberdade teórico-metodológica para realizar o estudo. A pesquisa é um percurso em construção, em que o caminho vai sendo traçado durante o percurso.

O essencial, segundo esse referencial, é o significado que as pessoas atribuem às ações e eventos, o modo como interpretam o mundo ao seu redor e como desenvolvem e compartilham valores, significados e crenças, não se preocupando com generalizações, princípios e leis: a generalização é abandonada e o foco de sua atenção é centralizado no específico, no peculiar, no individual, almejando sempre a compreensão e não a explicação dos fenômenos estudados.

Outro aspecto interessante é que o processo de condução da investigação qualitativa reflete uma espécie de diálogo entre os investigadores e os participantes (BOGDAN; BIKLEN, 1994). O pesquisador se apresenta no coletivo, afirmando sua influência sobre o processo, sua não neutralidade. A subjetividade presente nas relações entre pesquisador e pesquisado não deve ser evitada ou negada, mas explicitada e controlada por recursos teóricos e metodológicos (ROMANELLI, 1998).

Em se tratando de um estudo sobre o cotidiano escolar, um olhar mais próximo da escola permite entender como se operam as práticas, ações e representações, a linguagem, as formas de comunicação e seus significados, possibilitando descrever a situação e compreendê-la em seus múltiplos significados (ANDRÉ, 1989), e construir categorias que revelem tanto a interação como a distância entre a escola e o ambiente social (ANDRADE, 1990). Assim, a orientação etnográfica constituiu-se em uma possibilidade de envolver-se na dinâmica de produção deste cotidiano, e de compreender os sentidos que vem sendo produzidos na articulação entre escolarização e saberes, entre escola e comunidade. Como abordagem de investigação científica, a etnografia traz contribuições para o campo das pesquisas qualitativas que se interessam pelo estudo das microrealidades sociais.

A pesquisa do tipo etnográfico no cotidiano escolar volta-se para as experiências e vivências dos indivíduos e grupos que participam deste cotidiano e o constroem; portanto, agentes de transformação social, considerando a especificidade de suas ações e suas perspectivas. Intenta contribuir para revelar as relações e interações ocorridas no interior da escola.

Conforme Sato e Souza (2001), esta concepção afasta-se do funcionalismo e estruturalismo descolando-se do eixo das macroanálises para as relações cotidianas, que 
compreendem não somente aspectos microsociais, mas que, em sua face local, resgatam aspectos não apenas da história particular, mas também da semelhança destas relações com determinantes sociais e culturais que a cercam. Ezpeleta e Rockwell (1986) consideram que o estudo etnográfico aborda o fenômeno ou o processo particular, mas sem que se exclua este processo da totalidade maior que o determina, e com o qual mantém certas formas de relacionamento.

Focalizando no significado que pessoas ou grupos dão às práticas, há o interesse em relatar, o mais detalhadamente possível, as variações existentes no grupo participante. Alguns desses significados são diretamente expressos pela linguagem, outros são transmitidos indiretamente por meio de ações (MATTOS, 2004; ANDRÉ, 1995). Para isto, torna-se fundamental o contato direto e prolongado do pesquisador com a situação investigada. Este tipo de pesquisa produz grande quantidade de dados descritivos, acumulando descrições de locais, pessoas, ações, interações, fatos, formas de linguagem e outras expressões, que possibilitam ir estruturando o quadro configurativo da realidade estudada, num esquema aberto e artesanal de trabalho, que permite o transitar constante entre observação e análise (ANDRÉ, 1995).

A etnografia é um processo guiado preponderantemente pelo senso questionador do pesquisador, não havendo um padrão rígido ou pré-determinado na utilização de técnicas e procedimentos. Da mesma forma, seus fundamentos, instrumentos e técnicas podem ser permanentemente apreciados, reexaminados e aprimorados. Esta flexibilidade possibilita redescobrir caminhos, redefinir hipóteses, construir novas interpretações.

Todos estes aspectos se coadunam com os referenciais e conceitos-ferramenta da Análise Institucional, que afirma a necessidade de implicação do pesquisador, a impossibilidade de neutralidade científica, o enfoque microsocial e micropolítico, o não isolamento entre o ato de pesquisar e o momento em que a pesquisa efetivamente acontece na construção de conhecimento, situando, assim, uma proximidade entre sujeito e objeto, que deve estar em análise todo o tempo. O pesquisador é apreendido pelo próprio questionamento e deve ter uma constante postura interrogativa, numa mistura que envolve sensibilidade e aprendizado: questionar o que parece "natural", suspeitar do "corriqueiro", do "trivial", estranhar o aparentemente familiar. 


\section{Os Participantes da pesquisa}

Os participantes desta pesquisa constituíram-se dos agentes institucionais da escola e dos moradores da comunidade rural/ribeirinha onde se localiza a escola.

A escola possuía quatorze agentes institucionais, sendo um diretor, cinco professores, quatro auxiliares e quatro profissionais terceirizados, sendo uma merendeira, um motorista e dois vigias.

À exceção dos vigias, que se revezavam num turno de doze por trinta e seis horas, com horário de trabalho entre dezenove e sete horas, tendo contato restrito com os demais membros da escola, todos os agentes trabalhavam no horário diurno, no período entre sete e dezesseis e trinta horas. A maioria era do sexo feminino, sendo do sexo masculino dois professores, um auxiliar de serviços gerais, o motorista e os dois vigias. A idade variava entre vinte e quatro e cinqüenta e nove anos.

Os alunos podem ser considerados no universo da pesquisa, tendo em vista sua presença na escola durante a realização da observação participante. Todavia não foram entrevistados, por terem idades entre quatro e dez anos, em sua grande maioria. Considerou-se satisfatório o contato com os alunos nos momentos de observação participante.

Os moradores da comunidade podem ser considerados no universo da pesquisa, tendo em vista as conversas informais que a pesquisadora efetuou em momentos de circulação pelas ruas e igapós. Além disso, durante o período de observação participante, produziu-se a necessidade de um instrumento que pudesse apoiar a coleta de informações para a caracterização da comunidade. Assim sendo, elaborou-se um questionário para a construção de um perfil social básico. Este instrumento foi preenchido com a ajuda de quarenta e quatro moradores, abrangendo a totalidade das residências da comunidade. Oito moradores foram selecionados para participar das entrevistas.

\section{Local}

A coleta de dados foi realizada em uma comunidade rural ribeirinha, localizada em bairro periférico de uma cidade amazônica. Os dados foram predominantemente coletados na escola situada nesta comunidade, uma escola rural/ribeirinha da rede municipal de ensino que oferece a primeira etapa do Ensino Fundamental. Alguns dados foram obtidos em visitas às residências dos moradores e em momentos de circulação pela comunidade, momentos estes significativos para esta etapa. 
A escolha desta comunidade como lócus da pesquisa foi intencional, e se deu por configurar-se uma paisagem rural ribeirinha, em área de recente expansão da cidade, na fronteira entre rural e urbano. Esta incorporação tem promovido, nos últimos anos, impactos sociais e ambientais, alterações nos modos de vida e formas de enfrentamento das questões ambientais, econômicas e sociais, questões que até bem pouco tempo não figuravam no cotidiano destas localidades. Estas características compõem o perfil estabelecido para esta investigação. Além disso, a possibilidade de acesso rodoviário, diminuindo o tempo investido para se chegar ao local, e o conhecimento que a pesquisadora possuía da região, por já ter desenvolvido atividades de extensão e pesquisa em outras comunidades na mesma região, foram condições motivadoras para esta opção.

Em relação ao estabelecimento escolar, de modo geral, há apenas uma escola em cada comunidade.

\section{Procedimentos}

O trabalho de campo consistiu em um estudo de caso de cunho etnográfico, ancorado no referencial teórico-metodológico da análise institucional. Privilegiou-se o estudo de caso, considerando que o caráter exploratório possibilitaria a configuração de uma análise descritiva pormenorizada, permitindo profundidade na investigação, explorando características inéditas e dimensões até então pouco ou não conhecidas.

Os contatos que caracterizaram a fase exploratória foram feitos em duas visitas ao local, para expor a proposta de investigação, conhecer a localidade e as vias de acesso.

A observação participante constituiu-se no principal instrumento, e juntamente com as técnicas de entrevista semi-estruturada, registros documentais e o preenchimento de um formulário, possibilitou a triangulação das informações e uma descrição mais aprofundada da realidade estudada. O formulário foi utilizado para caracterização da comunidade e continha informações sobre os moradores, como idade, escolaridade, procedência, tempo de moradia, relações de parentesco, e sobre a infraestrutura nela existente. Os registros das situações e processos foram devidamente autorizados pelos participantes através do Consentimento Livre e Esclarecido, de acordo com os princípios éticos expressos na Resolução 196/96, do Conselho Nacional de Saúde, que normatiza pesquisas envolvendo seres humanos. A documentação para esta realização foi aprovada no Comitê de Ética da Universidade do 
Amazonas em 09 de julho de 2008, em conformidade com as determinações do Sistema Nacional de Informações sobre Ética na Pesquisa Envolvendo Seres Humanos (SISNEP).

A atividade caracterizou-se pelo contato direto da pesquisadora com a comunidade, que procurou envolver-se na dinâmica do cotidiano, e estabelecer relações com as pessoas, nas conversas informais, nas ações, no caminhar diário dos moradores, num esquema aberto, artesanal e de disponibilidade. A intensidade do envolvimento variou ao longo do processo de coleta, conforme as exigências e especificidades do próprio trabalho de campo.

As estratégias com as quais um pesquisador entra em contato com os participantes determinam, em parte, o sucesso da pesquisa e configuram-se em parte integrante do material de análise. O modo como este contato se estabelece influencia na forma como o pesquisador será recebido e no grau de disponibilidade para a participação e concessão de informações. Isto não significa dizer que há uma postura adequada; o caminho se faz ao caminhar. Mas concretizou preocupações.

Havia a preocupação constante de exercitar o diálogo, de estar com, estar disponível para a escuta, e de construir uma atenção flutuante, sem a prerrogativa do "olhar".

Outra preocupação consistia em atentar para os pequenos detalhes e atitudes que passam muitas vezes despercebidos e, consequentemente, ignorados. Uma atenção à espreita, um trabalho de escavação, orientado para os silêncios e silenciamentos, para as fronteiras, e para o que resiste.

Tinha-se presente, ainda, a preocupação de não encaixar as respostas nas perguntas da investigação, e de proceder à desconstrução do caráter individualizado e estereotipado das respostas, tão cristalizados em nossas práticas investigativas. Evitar, como diz Zaluar (2005, p. 122), "os sistemas fechados de explicação e hábitos viciados de repetir os mesmos procedimentos e as mesmas respostas aos mesmos velhos problemas".

Considerar também as implicações da pesquisadora, e assumir que a própria investigação produz efeitos. Uma pesquisa que atravessa e é atravessada pelas práticas em que quer se inserir (FERNANDES; ROZENOWICZ; FERREIRA, 2004).

O período de realização da pesquisa decorreu entre abril/2008 e janeiro/2009. O procedimento inicial foi o contato com a direção da escola, a fim de informar sobre a proposta da pesquisa e verificar a possibilidade de sua realização. Em seguida, procedeu-se aos encaminhamentos éticos e administrativos. A realização da pesquisa estava condicionada à autorização do distrito rural da Secretaria Municipal de Educação. No primeiro contato, estavam presentes a diretora, duas professoras e a agente operacional. A coleta de dados iniciou-se em julho/2008 e encerrou-se em janeiro/2009. 
O contato com os demais membros da escola foi se dando logo nos primeiros dias, procurando esclarecer os objetivos da pesquisa e a proposta de trabalho. Os primeiros contatos com os moradores foram intencionalmente não dirigidos por questionamentos por parte da pesquisadora, ou seja, aconteciam nos encontros pela rua ao ir e vir à escola, nos "bom dia", sem a mediação de qualquer instrumento.

O processo de inserção da pesquisadora foi rápido, havendo bastante receptividade e espírito colaborativo, tanto na escola, por parte da equipe de profissionais, como entre os pais e outros moradores. Em pouco tempo, sua presença na escola era considerada algo comum, parte do grupo; mas no início, houve muita curiosidade entre alunos e agentes sobre "o que esta professora estava fazendo na escola"? As reações foram interessantes. Os alunos perguntavam e ao mesmo tempo respondiam: "bem, só pode ser professora", "você vai dar aula aqui?" "ela é professora. Vai ficar com que turma?" Uma agente institucional que ocupava a função de apoio à direção, muitas vezes mirava a chegada da pesquisadora pelas grades do refeitório, incomodada. Posteriormente, pôde esclarecer: "eu não gostava de ti, sabia? Ficava me perguntando o que é que tanto essa mulher vem fazer aqui".

A diretora manifestou sua receptividade desde o primeiro dia, provavelmente identificada com a solidão do pesquisador, pelo fato de que sua filha também estava cursando pós-graduação em outro estado. Sua disponibilidade afastava os questionamentos, mas não as inquietações.

Circular pela comunidade contribuiu para a construção de um ambiente de familiaridade, considerado favorável à realização da pesquisa. Em alguns momentos, referiram-se à pesquisadora como "a amiga da escola". Todavia, isto também possibilitou que por muitos momentos as conversas girassem em torno de questões pessoais dos comunitários e suas famílias. Em alguns momentos, a pesquisadora foi consultada se seria professora na escola ou se faria reforço escolar.

A presença de uma psicóloga na escola remete aos "casos clínicos" e às dificuldades escolares. Apresentaram-se casos de alunos que necessitavam de acompanhamento especializado, mas o esclarecimento da proposta da pesquisa foi suficiente para o entendimento de que atendimentos clínicos não seriam realizados, e que não se tinha isto como perspectiva de trabalho.

Em vários momentos, receberam-se convites para participar de festividades, tanto pela direção da escola, como pelos professores e por moradores da comunidade. Dentro das possibilidades de tempo, esta participação foi correspondida.

No intuito de preservar a identidade dos que colaboraram com esta pesquisa, optou-se pela utilização de nomes fictícios como código de identificação. 


\subsection{A observação participante}

Esta observação propõe um contato direto com os participantes envolvidos na realidade estudada, recolhendo informações em seu contexto natural, a partir de suas perspectivas e pontos de vista (MINAYO, 1996). Possibilitou a vivência de situações de conhecimento sobre o mundo dos participantes, costumes, crenças, modo de vida, e também a percepção das características físicas da comunidade, da escola e do cotidiano escolar.

Foi realizada no período entre julho e dezembro de 2008, de forma randômica, três a quatro dias por semana, e sem informação prévia. A permanência em campo durava em torno de três ou quatro horas, mas o acompanhamento mais sistematizado de alguma atividade durava aproximadamente uma hora.

No início a observação não foi direcionada por fins específicos. Após um tempo, essa observação passou a ser mais diretamente sobre determinados aspectos, procurando focalizar com mais precisão os atravessamentos e implicações presentes no espaço escolar e nas relações com a comunidade, entendendo pais e alunos como membros da comunidade.

As observações foram registradas em cadernos, após a saída do campo, e posteriormente digitadas no computador. Houve poucos momentos em que este registro ocorreu em campo, por tratar-se de dados quantitativos ou quando não se queria perder detalhes de alguma informação. Durante o período de observação, foram feitas coletas de informações nos arquivos da escola, bem como cópia dos projetos e documentos históricos, ambos autorizados pela direção.

\subsubsection{Na escola}

As observações na escola ocorreram durante diferentes atividades escolares: nas aulas, no trajeto escola-casa, nas reuniões, nos eventos, nos espaços centrais e também nas esquinas. Objetivavam o conhecimento da rotina de funcionamento e dos atravessamentos presentes nas práticas cotidianas. Alguns indicadores nortearam a observação: no funcionamento da escola objetivaram-se a organização administrativa e pedagógica, a organização e utilização do espaço físico. Nas salas de aula, a ordem sequencial das atividades desenvolvidas durante a observação, a realização das atividades escolares, a relação professor/aluno, o relacionamento entre os alunos, os comentários dos professores e com os professores. Nas reuniões e eventos, as atividades realizadas, o relacionamento entre professores, direção, pais e demais agentes, e a interação com o observador. Foi possível acompanhar duas reuniões de planejamento, uma no mês de agosto e outra em outubro. Registraram-se fatos que foram de interesse da 
pesquisa, que ocorriam na entrada e saída dos alunos, no recreio, nas festividades: a disposição das cadeiras, os modos de relacionamento entre pais, discentes, docentes e demais agentes, as conversas paralelas e informais, as maneiras de se comportar, de calar e silenciar.

Interessava olhar os espaços instituídos, mas também as forças instituintes. Nesse sentido, momentos profícuos para este estudo ocorreram durante as aulas e reuniões, mas também nos momentos informais e em situações não especificamente programadas. O café da manhã tornou-se um momento disparador. As conversas foram momentos fortes, e importantes na construção dos dados. É no conversar que as pessoas se produzem e se posicionam nas relações que estabelecem no cotidiano.

\subsubsection{Na comunidade}

Os contatos entre os moradores e a pesquisadora aconteceram inicialmente nos encontros pelas ruas, ora caminhando para o trabalho na horta, ora retornando para as casas, ou na estrada que leva à comunidade. As observações privilegiaram conhecer as residências, os espaços de circulação e trabalho, bem como acompanhar conversas e os fazeres do dia a dia, obtendo informações sobre a comunidade, os motivos que os levaram a ocupar a área, as estratégias, os relacionamentos entre moradores, e entre eles e a escola. Foi possível identificar moradores-chave, os que exercem um poder simbólico na comunidade, e moradores significativos para o conhecimento do processo de construção histórica da comunidade, em geral, os mais antigos, mas não necessariamente.

Boa parte dos moradores estava bastante predisposta ao contato com a pesquisadora, curiosos sobre sua presença na escola, demonstrando interesse em participar da pesquisa. Já se conheciam alguns moradores, em função de um projeto da Universidade que foi desenvolvido em outra comunidade, no mesmo bairro. Algumas vezes, encontraram-se moradores que se ofereceram para contar "a história do bairro", ou mesmo para serem entrevistados, como se quisessem tratar de suas experiências e reflexões, há muito reservadas ou reprimidas, num trabalho ao mesmo tempo gratificante e doloroso. O interessante é que surgem dados que nem se pensaria em perguntar. Conversando especialmente com um destes moradores, entendeu-se que o tema ali tratado não correspondia à perspectiva deste trabalho, e concordou-se em desenvolver algum outro projeto que pudesse compartilhar com os moradores as demandas ali referidas, após o término da pesquisa. Esses encontros desencadearam a proposta de um levantamento sobre a comunidade que, inclusive, pudesse de algum modo subsidiar a associação comunitária. 


\subsection{As entrevistas semiestruturadas}

As entrevistas semiestruturadas foram realizadas no período entre novembro de $2008 \mathrm{e}$ janeiro de 2009, considerando que o momento anterior de observação participante pudesse contribuir para uma melhor ambientação e assim fornecer pistas para a composição do roteiro. A entrevista semiestruturada é uma técnica interrogativa fundamental para o estudo do cotidiano, pois fornece um esquema menos rígido de coleta de dados, que permite ao pesquisador fazer as adaptações necessárias. Parte da elaboração de um roteiro em que se pode enumerar de forma mais abrangente possível questões que se pretende abordar (ANDRÉ, 1989). O uso de um roteiro aberto permite liberdade de relatar para além do tema proposto e, ao pesquisador, a flexibilidade da condução e introdução de questionamentos que auxiliem a esclarecer dúvidas emergentes na dinâmica com o entrevistado.

\subsubsection{Entrevistas com os agentes institucionais}

Foram realizadas entrevistas individuais com cinco professores, sendo um do sexo masculino, a merendeira, e três auxiliares de serviços gerais, sendo um deles a auxiliar que foi deslocada de função para fazer o apoio à direção da escola, passando a ocupar uma função denominada agente operacional ${ }^{13}$.

O contato se deu no próprio local de trabalho, com agendamento antecipado de data e horário. Ainda assim, dois horários foram adiados. As entrevistas foram realizadas na escola, no horário matutino em sua maioria, com duração aproximada de uma hora. Uma entrevista foi realizada na residência da professora. Todas as entrevistas foram gravadas, e transcritas literalmente.

Utilizou-se um roteiro aberto, iniciando-se com questões relativas à formação, seguindo para a experiência em área rural, a docência rural e as relações entre escola e comunidade. A entrevista se iniciava com a fala da pesquisadora nos seguintes termos: "vou pedir a você que fale um pouco sobre sua formação e sua experiência em área rural". Não houve a preocupação com uma leitura rígida das perguntas; após esta fala inicial, os entrevistados eram solicitados a tratar do trabalho rural, o trabalho nesta escola em particular e a relação com a comunidade. Questões sobre o funcionamento da escola e o trabalho pedagógico decorreram no processo, com focos semelhantes em relação a determinados aspectos e outros singulares em cada entrevistado.

${ }^{13}$ Uma descrição detalhada de cada agente institucional encontra-se mais adiante, no capítulo sobre os resultados. 
Em alguns momentos, era preciso tomar cuidado para não se perder de vista os objetivos da pesquisa, pois se adotou uma postura de permitir ao entrevistado falar livremente, o que conduziu a alguns assuntos como alimentação, problemas de saúde, lembranças de suas experiências escolares e familiares. Mas, entende-se que estes assuntos, aparentemente desligados dos objetivos estabelecidos, conectam-se nas diferentes redes que se fazem presentes, encorpando a composição dos cotidianos escolares.

Procurou-se estabelecer uma atenção flutuante, sempre valorizando e considerando todas as informações trazidas. Cumpre ressaltar a disponibilidade por parte dos entrevistados em participar deste trabalho, fornecendo as informações solicitadas.

\subsubsection{Na comunidade}

As entrevistas com os moradores foram realizadas em suas residências, com data e horário previamente marcados, à exceção de uma participante, que quando consultada, comunicou estar disponível, e quis fazer a entrevista naquele momento. Esta abordagem se deu nos momentos em que se circulou pela comunidade, construindo-se a caracterização do local, ou quando se encontrava algum morador no caminho que conduz até a comunidade. Notou-se o interesse de vários moradores em colaborar com a pesquisa, pois o convite era feito apenas uma vez, para não caracterizar nenhuma obrigatoriedade, e muitos perguntavam quando seriam entrevistados.

Não se estabeleceu, a priori, o número de participantes a serem entrevistados. Baseouse no nível de saturação, interrompendo as entrevistas quando se considerou suficiente o volume de informações e constatou-se que novas informações não estavam sendo acrescentadas. Esta opção fundamenta-se nas recomendações de Minayo (1996), e Bauer \& Gaskell (2002), de que em pesquisa qualitativa não se trabalha com representatividade estatística; o critério não é numérico, mas deve ser estabelecido pela reincidência de informações. Todavia, considerou-se relevante a seleção intencional de moradores-chave e significativos, assim chamados pelo que representam em termos da história do local e da posição social que ocupam, e que, portanto, podiam trazer contribuições específicas para construir a história da comunidade e sua relação com a escola. Para os outros entrevistados, estabeleceu-se apenas que fossem pais de alunos matriculados na escola, e que houvesse pelo menos um representante de cada turma. Considerou-se, ainda, a possibilidade de abranger membros dos diferentes grupos familiares. 
Com base nisso, foram entrevistados oito moradores, sendo a presidente da associação comunitária, dois moradores mais antigos e cinco moradores cujos filhos estudam na escola. A duração das entrevistas foi, em média, de quarenta minutos.

\begin{tabular}{|c|c|c|c|c|}
\hline Pseudônimo & Idade & Escolaridade & $\begin{array}{c}\text { Filhos } \\
\text { matriculados } \\
\text { na escola }\end{array}$ & $\begin{array}{c}\text { Local de trabalho } \\
\text { no momento da } \\
\text { pesquisa }\end{array}$ \\
\hline João & 78 & Analfabeto & 0 & Não trabalha \\
\hline Pedro & 64 & Analfabeto & 3 & Horta \\
\hline Carla & 41 & Fundamental incompleto & 2 & Horta \\
\hline Miguel & 32 & Fundamental incompleto & 1 & Serv. temporários \\
\hline Raimunda & 32 & Fundamental incompleto & 2 & Horta \\
\hline Wilma & 28 & Ensino Médio & 1 & $\begin{array}{c}\text { Desempregada/ } \\
\text { Comércio em casa }\end{array}$ \\
\hline Rosa & 26 & Fundamental incompleto & $3 \mathrm{a}$ & Horta \\
\hline Erilene & 23 & Ensino Médio & 1 & Comerciária \\
\hline
\end{tabular}

Quadro 1 - Descrição dos pais entrevistados

O roteiro de entrevista continha questões abertas, e isto possibilitou que as conversas pudessem ser menos formais. Algumas respostas foram do tipo "resposta curta", momentos de silêncio, e mais intervenções da pesquisadora. Outras deslancharam para histórias pessoais e da comunidade. Aqui também houve a preocupação de ouvir, acolher e valorizar as informações apresentadas. Em relação ao sexo, predominou o sexo feminino, na proporção de cinco por três.

\subsection{Análise documental}

A análise documental teve como objetivo corroborar com outras fontes para a contextualização da comunidade e apoiar na caracterização da escola, descrevendo-a em termos de: clientela atendida, estrutura física, serviços, organização pedagógica e administrativa. Os seguintes documentos foram disponibilizados pela direção da escola: o Projeto Temático, o Programa de Redimensionamento da Educação Básica, os projetos mensais dos professores e os arquivos históricos.

Em relação à comunidade, foram analisados informativos sobre o bairro, livretos, arquivos históricos, decretos dos órgãos públicos municipais. Buscaram-se junto aos órgãos públicos documentos e informações relativos à história do bairro e sua ocupação.

Procurou-se ter o cuidado no uso dos documentos para que não fossem tomados como registros literais de eventos que ocorreram, comparando com informações obtidas com os moradores. 


\section{Análise dos dados}

A leitura e análise qualitativa dos dados foram realizadas conforme o método da análise de conteúdo temática, proposto por Bardin (1977), e com base no aporte teórico fornecido principalmente pela Análise Institucional. Sua utilização é adequada à análise de textos, sejam os publicados ou os discursos circulantes.

Operacionalmente, a análise de conteúdo parte de uma leitura de primeiro plano; e, através de um conjunto de técnicas complementares, possibilita a observação detalhada do material coletado, e a explicitação e sistematização do conteúdo das mensagens, buscando apreender as diferentes vozes do grupo, as ideologias e os conteúdos ocultos.

Atenta-se para os passos descritos na análise temática: pré-análise, exploração do material e tratamento dos resultados obtidos e interpretação.

Foram efetuadas leituras e releituras do material coletado e registrado no caderno de campo, e nas transcrições das entrevistas, para obter as primeiras impressões e mensagenschave emitidas pelos participantes. Nesta etapa inicial, procurou-se manter uma atenção como "concentração sem focalização" (KASTRUP, 2009), numa atitude que prepara para o acolhimento do inesperado. Em seguida, organizou-se o conjunto das informações a serem analisadas, estabelecendo o corpus do trabalho. Procuraram-se, também, alguns indicadores que possibilitassem inferir o significado latente dos enunciados e os fatores que determinaram as condições de produção das mensagens.

Posteriormente, os temas principais foram ordenados e classificados, a fim de se encontrar conteúdos mais recorrentes e significativos, para o estabelecimento das unidades de registro. Na organização deste material, procurou-se listar tudo o que figurou, considerando a intensidade com que os dados se apresentavam. Este procedimento envolveu mapeamento, recorte de episódios, agrupamento dos dados, construção de tabelas, busca dos temas centrais. Em casos de interseção, optou-se pelo tema predominante. Discursos que possuíam dados expressivos para a discussão foram recortados para exemplificar. A classificação dos dados objetivou a construção das categorias empíricas.

A terceira etapa, referente ao tratamento dos resultados obtidos e interpretação, constituiu a articulação mais minuciosa entre o material empírico e os referenciais teóricos da pesquisa, respondendo aos objetivos traçados, buscando uma interpretação e compreensão dos resultados, e formulação de conclusões sobre as conexões encontradas. 
Para pensar as categorias ordenadoras e de análise, tomaram-se como referência os objetivos propostos nesta pesquisa. Assim, a partir da relação entre os temas estabelecidos nos objetivos específicos e as releituras dos registros das informações produzidas nas observações, na análise dos documentos e entrevistas, organizaram-se os dados inicialmente em quatro grandes agrupamentos: o bairro, a escola, o processo pedagógico e a relação escola-comunidade.

O primeiro grupo refere-se à caracterização e contextualização do bairro e da comunidade; o segundo aborda o contexto escolar, caracterizando seu cenário, agentes, clientela, relações espaçotemporais e dinâmicas cotidianas. No terceiro grupo, tratou-se das práticas que emergiram como visibilidades, e no quarto grupo de categorias abordou-se a relação escola-comunidade, o que pensam a clientela e os agentes institucionais sobre a escola, as expectativas em relação à escolarização e à participação.

$\mathrm{O}$ mergulho que se propôs a fazer nesta experiência, e as incursões nos autores que serviram de apoio à pesquisadora e que, por outro lado, também a desafiaram, foi lentamente delineando outras aproximações, e a necessidade de adaptações ao método de análise inicialmente proposto. Quer-se considerar a multiplicidade de atravessamentos presentes e constituintes de qualquer suposta unidade, procurando não limitar o trabalho à descrição do que é feito, mas entender o que ali se produz. Para isto, recorreu-se a pistas propostas pelo método cartográfico, atrevendo-se a pinçar das teorias as ferramentas capazes de oferecer auxílio neste propósito, e mantendo presente a análise das implicações específicas da pesquisadora.

Permanentemente atravessados nesta codificação e análise estiveram os questionamentos sobre como esta pesquisadora se situou neste movimento. Está-se permitindo mergulhar, ou ainda se é guiado unicamente pelo sentido da visão?

As angústias de como fazer uma descrição para dar conta do que se quer olhar, marcar, anunciar, foram lentamente cedendo às considerações de que esta pretensão não se sustenta. A seleção e análise dos dados não atingem a amplitude das informações produzidas em campo, muito menos as múltiplas possibilidades do cotidiano. Esta é, dentre outras, uma forma possível de abordar o fenômeno estudado. Fenômeno este que é um fragmento deste plano de constituição. Por isso, as conclusões são sempre provisórias, parciais. Construindo-se um ângulo próprio de visibilidade, sem nenhuma pretensão de apreender a totalidade, intentou-se asseverar a possibilidade de provocar outros mergulhos. 


\section{RESULTADOS}

Neste capítulo, apresentam-se os resultados obtidos a partir da análise dos documentos, dos registros das observações e das entrevistas. Iniciou-se com uma breve caracterização do bairro e da comunidade. Sua história de ocupação traz informações significativas para a análise das mudanças ocorridas na localidade.

\section{O Bairro}

O bairro localiza-se na zona leste da cidade e compreende um ambiente de terras, águas e florestas, no limite entre áreas rural e urbana. Possui extensas áreas florestadas em uma microbacia hidrográfica que deságua numa foz alargada, formando um grande lago, sendo esta a maior bacia de interesse ecológico, inteiramente inserida no município. Apesar de vir sofrendo significativos impactos ambientais em função da expansão urbana e da ocupação desordenada ao longo de seus canais, ainda se encontra preservada.

Como área de expansão recente, e criado em um modelo econômico que tem promovido o rápido crescimento demográfico e o agravamento das condições de vida nas cidades, o bairro vem experimentando na última década, profundas e rápidas mudanças, sobretudo no que diz respeito à produção dos espaços de moradia e de trabalho, e na desarticulação das formas tradicionais de enfrentamento dos problemas econômicos, educacionais, de saúde, enfim, ambientais.

Sua condição como bairro é singular: compõe-se de pequenos aglomerados, entremeados de sítios, fazendas, florestas densas e áreas alagadas, constituindo comunidades, rurais e ribeirinhas, distribuídas no interior e ao entorno do lago, e na estrada que dá acesso ao bairro, compondo assim um cenário muito diferente de outros bairros da cidade. Cada comunidade possui sua própria denominação, havendo uma comunidade central, que leva o nome do bairro. A maioria tem um santo padroeiro que lhe dá o nome, e alguma organização políticossocial, o que dá ao bairro a quantia de oito associações comunitárias. Em termos de ocupação, possui baixa densidade populacional, a menor do município, havendo cerca de cinco mil habitantes em uma área de 658,20 hectares de superfície bruta. E também a menor renda per capta. Dista cerca de trinta quilômetros do centro urbano e, até a década de 1980, manteve-se como uma comunidade isolada, cujo acesso dava-se apenas por via fluvial, uma 
distância aproximada de duas horas e meia de motor. Um bairro fronteiriço, visto que ainda há predominância do modo de vida rural, mesmo estando em gradativo avanço urbano.

As primeiras informações que se tem desta localidade datam do século XVIII, por ocasião da viagem de Alexandre Rodrigues Ferreira, indicando-o como um dos três pesqueiros de tartarugas da Fazenda Real, destinado a sustentar os empregados da Real Demarcação dos Domínios Portugueses (FERREIRA, 1972). Anteriormente, no século XVII, o Padre João Daniel (1976) mencionara em seu códice "Tesouro descoberto no rio Amazonas" a produtividade pesqueira de lagos e igarapés.

Conforme informações dos moradores, a ocupação data do início do século passado, com a chegada de quinze famílias oriundas de outras regiões da Amazônia, após o declínio da borracha, instalando-se à margem do rio principal, na várzea. Esta ocupação tem sua constituição associada a um conjunto de fatores, dentre os quais o êxodo dos seringueiros, a existência de um ambiente propício à fixação próximo de um centro urbano, a possibilidade de garantir as condições básicas de sobrevivência neste ambiente aquático e de posteriormente trazer suas famílias.

Em torno da década de 1960, um pequeno núcleo comunitário foi organizado com apoio de uma irmandade de freiras católicas. As cheias, inundações e o fenômeno das terras caídas (erosão da margem do rio), foram levando os moradores a recuar suas moradias, até que, por insistência das missionárias e em virtude de uma grande cheia que derrubou casas arrastando uma criança pela correnteza, transferiram paulatinamente a comunidade para terra firme, às margens do lago, entre 1972-75, local onde atualmente se localiza a vila central do bairro, doravante denominada Vila. Com apoio da ação missionária, a comunidade conquistou a implantação de um centro social, um posto médico e um espaço para a escola que, desde 1935 funcionava na casa da professora.

Desenvolveram um modo de vida centrado na extração de produtos florestaisaquáticos e na agricultura de subsistência, tendo na pesca sua atividade principal. Um modo de reprodução social que permitia um equilíbrio entre a exploração dos recursos naturais e a capacidade de regeneração da natureza e que, na perspectiva deste trabalho, pode ser incluído no conceito de cultura tradicional ribeirinha.

As atividades produtivas eram centradas no setor primário, e vinculadas ao aproveitamento dos recursos naturais do meio circundante. Mesclavam atividades agrícolas e extrativistas, conforme as alterações sazonais no ciclo enchente/vazante, como o cultivo de hortaliças para consumo doméstico (temperos), a mandioca para a produção de farinha, a 
pesca, o corte de madeira e a extração de frutos como tucumã, buriti, pupunha e bacaba, sempre assentado na produção familiar.

"Tinha nada não. A minha velha teve um bebê, foi eu que peguei o bebê dela, era uma vida muito triste era. Aí eu comecei a plantá roça, isso aqui tudo era de roça. Depois peguemo na farinha [...] Ai comecei a fazer carvão, tinha o Pereira, o motor, a sra conheceu o seu Pereira? Tinha um motor bom, o cumpadre Bento morava lá na varge, então isso foi acertado" (Sr. Leo).

"Aqui tinha muita fartura. Aqui não morava ninguém, só morava muito macaco e porco, era o que tinha aqui nessas mata [...] não tinha igreja, não tinha escola, não tinha nada. Só, via macaco no galho de pau. Pescá, não ia longe, tinha de um tudo. Era jaraqui, pacu, tambaqui. Era assim aqui. Esse campo ai era um tucumanzal" (aponta para a horta) (Sr. João).

"Ali, pra onde hoje é a escola, dali pra baixo, tinha muita abacaba; a gente entrava na mata para tirar abacaba, tucumã. [...] Ih, era farto de tambaqui, paca, anta. Mas era uma vida muito sofrida, já sofri muito nessa vida” (Sr. Pedro).

A pesca, caracterizada como uma atividade de subsistência das mais tradicionais desenvolvidas pelas comunidades ribeirinhas, era artesanal, realizada com a utilização de instrumentos simples, confeccionados pelos próprios pescadores. Os jovens geralmente acompanhavam seus pais na pescaria, e às mulheres destinava-se o serviço doméstico, o cuidado dos filhos e da pequena produção agrícola na ausência do marido. Com a possibilidade de comercialização de produtos nos centros urbanos e com a aquisição de equipamentos para construção de uma casa de farinha, a atividade econômica principal passou a ser a produção de farinha de mandioca e carvão vegetal, além da pesca de subsistência.

O acesso fluvial manteve a comunidade parcialmente isolada do centro urbano até a década de 1980, quando, por iniciativa dos próprios moradores, apesar de o poder público considerar a obra inviável, construíram uma estrada. Conforme relato dos moradores, durante duas semanas, quinze homens abriram uma picada pela mata até alcançar a estrada mais próxima, aproximadamente $15 \mathrm{~km}$ de percurso, entre mata primária, declives e aclives.

"E essa estrada aí, fomos nós que fizemo essa estrada, com essa turma aí da [...] Participei, da estrada, isso aí, nos trabalhava, é quinze homem dentro aí dessa estrada, foi quiiiinze homem aí trabalhando. Vou dizer quem foi (cita os nomes) o João também participou da carrera, ele também ainda é vivo. E o resto acho que já morreu tudo" (Sr. Pedro).

"Fumo embora aí voltemo de novo pra cá, voltemo. Aí fiz aquele pique, com finado Mauro, o Chaves, fizemo o pique té na gurita. Tiremo o corte, o Mauro é que ia guiando. Aí ficou só um pique aí (aponta para a estrada). Eu 
e João chave que ainda ta vivo. [...] Pelejemos lá pelo lado do Canal, não deu, pelejemo por baixo, pela cabeceira não deu, aí é que nós tiremo por aqui; aqui deu certo, aí ficou só o pique ai. E nos se mandemo pra Mauá (mudou-se com a família para outra cidade). Macaco no galho de pau, era assim (movimento unindo as pontas dos dedos da mao direita, indicando grande quantidade). Esse campo aí era um tucumanzal. Aí quando voltei de lá, de Mauá de novo, aí já tavam desmatando pra estrada, desmataram tudo" (Sr. João).

A construção da estrada pode ser considerada um marco significativo na promoção de mudanças, alterando a dinâmica de vida, do deslocamento à economia. Com ela chegou energia elétrica e a água encanada, após a construção de um poço artesiano para abastecimento da comunidade; o transporte rodoviário, que apesar de precário, facilitou acesso a outras localidades, e consequentemente ao sistema de saúde, centros comerciais, escolas, mercado de trabalho, etc. Motivou moradores de outras comunidades no interior do lago a ter também um espaço na Vila, "uma casa à porta da estrada" para ser utilizada em momentos de necessidade. Trouxe maior circulação de pessoas, que passaram a frequentar o local como opção de lazer. Marcou também o processo de organização da comunidade na luta por seus interesses e melhores condições de vida, haja vista sua construção ter sido um empreendimento dos moradores na contramão do suposto conhecimento técnico.

Por outro lado, facilitou um rápido e contínuo processo de modificação das estruturas econômicas, sociais e ambientais: mudanças no modo de vida dos moradores e relações sociais, dos hábitos cotidianos às relações de vizinhança; mudanças nas relações com os meios de produção, com a passagem da atividade predominantemente agrícola e pesqueira à atividade comercial/turística, pois, tendo nos recursos hídricos um dos seus principais atrativos, a facilidade de acesso contribuiu para o surgimento de pequenos comércios e bares, e dos passeios de barco pelo lago, em geral, nos fins de semana. O turismo e a criação de peixes em cativeiro (pelo uso da tecnologia dos tanques-rede ou de gaiolas no meio do rio) se constituíram em alternativas à geração de renda. Possibilitou ainda sair do bairro à procura de outros empregos e maior escolarização.

O acesso também promoveu o aumento da demanda por terrenos e moradias, favorecendo o parcelamento do solo e incrementando a especulação imobiliária, com a venda de lotes, terrenos ou sítios, em duas versões que convivem e contrastam: por um lado, a opção de uma moradia mais popular, e por outro, a construção de casas de veraneio. E assim, a população, que em 1980 era menor que mil habitantes, passou, em 2000, para cerca de três mil e, em 2007, para mais de cinco mil habitantes. (IBGE, 2008; 2000). Com os novos assentamentos, uma nova configuração, e aspectos de periferia urbana. 
Foi somente em 1995 que a localidade foi oficialmente incorporada ao perímetro urbano, através de um Decreto-Lei municipal, que redefiniu os limites geográficos da cidade, dispondo sobre a identificação, delimitação e incorporação de novos bairros.

Entretanto, apesar de nova categorização, a condição de bairro não se traduziu em melhoria da infraestrutura local, nem mesmo em termos de aquisição de equipamentos urbanos. Ao contrário, o bairro permaneceu sem cobertura municipal. A Vila e as demais comunidades mantiveram uma formatação agrorribeirinha, com difícil acesso aos serviços básicos de educação, transporte, saúde e saneamento, acrescido de pouca oferta de trabalho. Em todo o bairro, não há posto de saúde, posto policial, farmácias, agência de correios, bancos ou outros serviços. Não há ensino médio, nem titularidade das terras. Os moradores são posseiros, em sua grande maioria. Há conflitos de terras, pequenos, silenciosos. A comunidade aprendeu a se calar, e a buscar apoio junto a políticos.

O bairro conta com pequenas casas comerciais, dois templos católicos e algumas igrejas evangélicas e pentecostais. O sistema de abastecimento de água é feito através de poços artesianos, sob controle das comunidades, e sem fiscalização da vigilância sanitária. Não há rede de esgoto. As casas possuem fossas rústicas e há casas que não possuem banheiros; a água servida circula a céu aberto. Ainda há comunidades que não possuem rede de energia elétrica, dispondo de um gerador elétrico que funciona com recursos dos próprios moradores. Mesmo com os investimentos realizados pelo Programa Federal "Luz para todos", o contexto rural ainda enfrenta acentuada precariedade em termos de prestação de serviços energéticos e condições de acesso aos mesmos. Conforme Santos (2005), é no mínimo instigante que, numa região com vasto potencial de recursos energéticos, as políticas do setor de energia, além de não contemplarem de forma satisfatória as necessidades de grande parcela dos povos locais, apresentem incompatibilidades em relação às peculiaridades regionais. Há uma linha de ônibus, que liga o bairro ao centro da cidade, em intervalos que variam entre quarenta minutos a uma hora ou mais, mas para quem mora nas comunidades no interior do lago, a locomoção é feita por conduções próprias, barcos a remo ou motor (motor de popa ou motores entre 15 e $40 \mathrm{HP}$ ).

Em termos dos serviços públicos disponíveis, registra-se na área da saúde a existência de apenas um posto de atendimento, onde funcionam programas de prevenção, e o controle de malária e dengue. A não existência de um centro de saúde obriga os moradores a recorrerem a outros bairros, principalmente em situações de urgência e emergência. Há o sistema de coleta de lixo, o cemitério e a escola. Contam-se nove escolas de Ensino Fundamental, sendo duas urbanas e sete rurais. A maioria oferece a primeira etapa do Ensino Fundamental, ou seja, do primeiro ao quinto ano. Apenas duas escolas atendem à segunda etapa, entre sexto e nono ano; uma delas é 
urbana, e faz a oferta regular das disciplinas. A outra é rural, e oferece disciplinas no sistema modular. As escolas rurais ribeirinhas trabalham no regime de classes multisseriadas. A inexistência de uma escola de Ensino Médio constituía-se em grande queixa dos moradores, por fazer com que os jovens tivessem que se deslocar a outras localidades para dar continuidade aos estudos. Muitos encerravam na oitava série sua carreira escolar. Uma escola estadual de ensino médio foi inaugurada em junho de 2010, localizada na Vila, para atender a todo o bairro.

Também há pequenas e médias propriedades rurais, hotel de selva, áreas de lazer denominadas "banhos" e belas casas de veraneio. É interessante observar que não há praças, mesmo na parte urbana do bairro. Os espaços públicos de encontro são as águas, as ruas, as calçadas e algumas áreas descampadas para o jogo de futebol (que geralmente têm dono). Algumas comunidades dispõem de um "chapéu de palha" para festas e encontros religiosos.

A presença da missionária exerceu grande influência na constituição das primeiras comunidades. Foi responsável pela implantação do centro social comunitário, do posto de saúde e da formação da primeira associação de moradores, conseguindo doações, parcerias e financiamentos, além de tratamentos e medicamentos, e indicações para empregos públicos, como contrato de agentes de saúde, de professoras e de um funcionário local da companhia de energia elétrica. Mas não promoveu a organização comunitária nem a criação de CEB's. Atualmente, o catolicismo tem decrescido, havendo nas comunidades um aumento significativo de igrejas pentecostais.

\subsection{A Comunidade}

A comunidade em estudo é uma das mais recentes ocupações do bairro. Foi construída em fins da década de 1990, como resultado da demanda por terrenos após a construção da estrada, no duplo movimento: moradias mais baratas com acesso rodoviário, e por terrenos para instalação de sítios e casas de veraneio, às margens dos igarapés. Localiza-se à margem do igarapé de mesmo nome, próxima à área principal do bairro. Sua área é delimitada por sítios e uma horticultura, havendo apenas uma rua que lhe dá acesso.

Compõe-se de cinco pequenas ruas, com quarenta e uma unidades domésticas e aproximadamente duzentos habitantes. Todas as residências se comunicam por terra. As casas são simples, a maioria de madeira ou mista, coberta com telhas de alumínio, contendo três ou quatro cômodos. A palha não é mais usada para cobertura das casas, mas apenas em "chapéus de palha" nos sítios de veraneio. Segundo relato de um morador, as primeiras casas eram cobertas por palhas, mas a cada dia torna-se mais difícil consegui-la, pois todo o entorno está 
ocupado pelos sítios cujos terrenos foram desmatados; é preciso ir cada vez mais longe para tirar produtos da floresta. Mesmo os terrenos mais distantes também têm donos, e os moradores nem sempre são autorizados a entrar. Além disso, com a valorização do "ambiente natural”, comprar a palha sai mais caro do que o material de construção.

Três residências também funcionam como modestos estabelecimentos comerciais. Há duas igrejas pentecostais em uma mesma rua, uma escola municipal de ensino fundamental e a sede provisória de uma Organização da sociedade civil de interesse público (OSCIP), que permaneceu fechada por todo o período em que a pesquisadora esteve em trabalho de campo.

Diferente das comunidades ribeirinhas, esta possui o formato de loteamento ${ }^{14}$, ou seja, conjunto de casas distribuídas em duas quadras, em terrenos padronizados, cercados, que medem aproximadamente $120 \mathrm{~m}^{2}$. Na primeira quadra encontram-se a maioria das casas e as igrejas; na segunda, quatro casas, a sede do Centro Social, a escola e um sítio, todo cercado por um muro de mais de dois metros de altura. A área da escola ocupa metade da quadra.

Contornando a comunidade, às margens dos igarapés, encontram-se doze sítios e casas de veraneio, em terrenos no mínimo vinte vezes maiores que os das casas da comunidade. Esta área é considerada mais valorizada em função do acesso à água. Para ter acesso ao rio, os moradores da comunidade precisam passar por dentro dos sítios.

Há ainda uma horticultura, localizada na rua que dá acesso à Vila, cujo terreno é maior do que o ocupado pela comunidade. É nesta e nos sítios que a maioria dos moradores trabalha.

O primeiro morador chegou ao local na década de 1960, instalando-se, constituindo família, e ali permanecendo com o consentimento dos donos do terreno ${ }^{15}$. Em seu relato, este morador fala da fartura e das dificuldades.

\begin{abstract}
"Bacaba, tucumã, vendia pra viver, né? Agora meus filhos foram criados na fartura. Isso aqui tudo era um bocado de roça, isso aqui, isso tudo aqui. Eu botava pra trabalhar com oito pessoas, eu, minha mulher, meus filho, e um parente. Quer dizer então eu trabalhava com oito, ia até essas terras aqui embaixo. Aí, depois que eu, que a bíblia falou que trabalhador tem merecimento. [...] Isso aqui era muito farto, de paca, tambaqui, até trinta anos, era muito farto de tudo, oi! Era ruim por causa da, da, da farinha, açúcar, café, é, eu plantava cana pra fazer (adoçar) o café. Fazia aquele feixe, moía, um sofrimento muito grande, ó. Mas nós, meus filho foi criado, graças a Deus, Deus não deixou morrer nenhum. Morreu um, o coisa, como é o nome dele? O Mateus; morreu. Mas ah, não tinha médico, né. Aí eu, era pouco. Já veio duma situação ruim, né” (Sr. Pedro).
\end{abstract}

\footnotetext{
${ }^{14}$ Observe-se que este formato é característico dos bairros de periferia.

${ }^{15}$ Os donos dos terrenos eram filhos dos fundadores da comunidade original, os que chegaram e tomaram posse daquela localidade no início do século passado. Há um documento lavrado em cartório, que data de 1907, indicando a propriedade da terra.
} 
Lentamente outros moradores foram se instalando.

"Não, é porque eles vinheram, né, se apossar das ilha (localizadas no igarapé, em frente à área da comunidade). Aí quando veio umas dona, dizendo que era dona das terras dali do outro lado, eles foram se achegando pra cá. Eu não fazia questão, pra não brigar com ninguém, né, e deixava, coitados. Aí veio uma pá do Laurindo (família com muitos filhos), a família do Lazo, ai foi, modificando, né, e foi" (Sr. Pedro).

Até o início da década de 1990 havia cinco famílias na localidade. Estimulados pela demanda e alegando que os ocupantes estavam vendendo lotes, os donos retomaram as terras, promovendo o parcelamento e venda de áreas com preços variados, dependendo do poder aquisitivo do comprador. O valor da terra, inicialmente irrisório, foi aumentando com o tempo, em virtude da valorização ambiental propagada pela mídia, que cria demanda por espaços em contato com a natureza.

Conforme depoimento de um morador, um pastor adquiriu boa parte do terreno, para lotear e revender aos fiéis, objetivando ali a construção de uma comunidade evangélica. Esta informação não foi confirmada por outros moradores; no entanto observou-se que os moradores são majoritariamente evangélicos, e não há características das comunidades católicas, ou seja, não há capela, sede comunitária nem campo de futebol; não possui santo padroeiro nem festejos; a comunidade e as ruas não têm denominações de santos, mas nomes dos lagos e igarapés próximos. Nas conversas com os moradores, é recorrente o discurso evangélico.

"Muito trabalho, mas o Deus é bom na vida do homem, eu vi um homem
pegá ali tanto balaço e não morreu. Póe Deus na vida dele, né, como Deus é
bom. Aquilo que Deus ama ele não morre não. Morre, mas depois de
guerrear, de cumprir né com o que tem" (Sr. Pedro).
"Os filhos, eu entrego na mão de Deus, tudinho eu entrego pra Deus", (Raimunda).

"Hoje nós estamos aqui, e..., alegre e feliz, né, por Deus ter concedido isso tudo pra nós, né. Porque tudo que está acontecendo aqui, é por Deus. Porque Ele é o nosso pai" (merendeira).

Em termos de equipamentos urbanos, a comunidade só possui uma escola rural que oferece a primeira etapa do Ensino Fundamental. Até 2001, não havia energia elétrica, nem água encanada. A chegada de dois moradores, o Sr. Mário e dona Carla, movimentou a comunidade. Recebendo apoio dos proprietários de um dos sítios, fundaram a associação de moradores no ano 2001. Objetivando a conquista de melhorias para a comunidade, procuraram representantes do 
poder executivo local, que pudessem apoiar suas reivindicações. Conforme depoimento de D. Carla, atual presidente da associação de moradores, ela espalhou várias solicitações e diariamente ia aos órgãos públicos acompanhar os processos. Mas sem a influência de um político, “de preferência um bom deputado", os caminhos são mais difíceis. Comentou que um dia, na Secretaria de Educação, não sabe por que motivo começou a chorar, argumentando as dificuldades que passavam para levar os filhos à escola. Descobriu nisto uma estratégia e ficou conhecida como "lá vem a chorona", mas não desistiu até conseguir a escola. Conseguiu a construção de dois poços artesianos, um através de uma ONG e outro pela prefeitura. Os moradores se cotizaram para comprar os canos e conexões da malha principal, fazendo um mutirão para a realização do trabalho. A partir daí, cada morador faria o encanamento para dentro de sua casa. Em 2008, um poço foi cedido para abastecimento quase exclusivo da escola (a diretora autorizou a ligação para três casas que ficam à frente da escola), e o outro ficou para a comunidade. A prefeitura arcava com as despesas da conta de luz, mas não fazia manutenção nem análise da qualidade da água. Não há rede de esgoto, a água servida é absorvida nos quintais e pouca quantidade desce por uma das ruas. A tubulação de água, feita pelos próprios moradores, está exposta, e em alguns pontos apresenta vazamentos e emendas improvisadas. Em visitas às casas, observou-se que a maioria das não possui caixa d'água suspensa, são tanques ou latões que ficam no chão, numa área externa, geralmente perto da cozinha. Algumas casas possuem fossas rústicas e outras não possuem banheiros. Não há rede telefônica nem transporte coletivo. Os moradores precisam andar até a Vila para pegar ônibus.

Quanto aos moradores, a maioria possui laços de parentesco. Quase todos pertencem a três grupos familiares, havendo casamentos entre eles. Alguns nasceram na localidade, mas o aumento populacional se deu nos últimos seis anos. É interessante observar que antes de vir para a comunidade, muitos moradores viveram em bairros na periferia do centro urbano. Vindos do interior em busca de uma vida melhor na cidade, tiveram dificuldades em se adaptar, e encontraram neste local a possibilidade de viver com tranqüilidade e segurança, distante da turbulência e violência do centro urbano.

A maior parte das famílias é composta por cinco ou seis membros, com filhos em idade escolar. Destes, aproximadamente metade possui menos de doze anos e estuda na escola da comunidade. Os pais passam a maior parte do dia no trabalho. Os filhos, quando não estão na escola, ficam em casa ou na rua brincando, sob cuidado de um irmão mais velho ou algum parente. Em alguns casos, trabalham junto com os pais, aumentando a renda familiar, pois ganham por produção. Há um número significativo de jovens que constituíram família e abandonaram os estudos. O nível de escolaridade está predominantemente localizado no 
Ensino Fundamental incompleto, mas tem havido uma tendência de os moradores mais jovens, principalmente do sexo feminino, retornar aos estudos supletivos. O nível sócioeconômico é baixo, com salários variando entre meio e dois salários mínimos.

$\mathrm{O}$ relato de um jovem de vinte e oito anos ilustra bem as dificuldades enfrentadas pelos ribeirinhos em suas aventuras escolares. Abaixo, apresentamos parte de um diálogo entre a pesquisadora e este jovem, ocorrido no período de observação participante, nos momentos de circulação pela comunidade.

Paulo - Estudei até a segunda série, lá no Cravo. Só que lá era porque eu não ia mesmo, mas lá o colégio era bom.

Pesquisadora - Ah, você é que não ia?

Paulo - É, eu ia, chegava no meio do ano, desistia.

Pesquisadora - E por que desistia?

Paulo - Não sei, é..., lá eu gostava de pescar. Nessa época eu morava com a minha mãe, tinha uns oito anos.

Pesquisadora - Você então estudou dos oito até uns dez anos, e parou.

Paulo - Foi. Acho que foi isso.

Pesquisadora - Vou dar umas palmadas na tua mãe.

Paulo - Mas não era culpa dela, não, eu que não dava pra estudar mesmo. [...] No meio do ano, a gente parava, desistia.

Pesquisadora - Mas o que você achava da escola?

Paulo - Eu achava legal.

Pesquisadora - Mas alguma coisa fazia você sair da escola?

Paulo - É. A preguiça também, né, de manhã cedo, e era longe, acho que era uns doze quilômetro, mais ou menos.

Pesquisadora - Caramba!

Paulo - Se a aula era lá uma hora, tinha que sair é, oito, nove hora lá de casa, a pé,

Pesquisadora - Ah, então isso não é preguiça, isso é sacrifício.

Paulo - Era bem interior. Lá, era, ficava pra depois do Marau.

Pesquisadora - E aí tinha que ir a pé pra escola?

Paulo - Tinha; ir a pé. Quando alagava tudo a gente ia de motor. Na seca, quando seca não tem motor que entra. Assim ó, na várzea, ficava lá no fim. Existe agora, lá, um micro ônibus que vai, mas antes não tinha. Até a rua perto da escola era esburacada. Ainda é.

Pesquisadora - O motor era da escola?

Paulo - Não, era fretado, né, que a escola não tinha.

Pesquisadora - Quem fretava?

Paulo - O governo. O transporte que dava, não chegava até onde a gente morava [...]. 
Outro relato ilustra o empenho de quem insiste em permanecer nos estudos.

\begin{abstract}
"Vou pra casa. Todo dia essa rotina, de três pilar, aqui, lá e lá. É um pouco sacrificoso, mas, mana, a gente chega na faculdade, olha, é pra gente ter muita força de vontade, porque senão tinha desistido. Muita força de vontade. Principalmente se, quando é só chegar na Vila e entrar dentro de casa tudo bem, mas pega barco, vai, dez a quinze minutos de motor, alta hora da noite, que às vezes perdia o ônibus, né, que não podia sair cedo da faculdade, porque ainda tinha trabalho pra fazer, né, se eu perdesse o onibus de dez pras dez, mana, só dez e trinta. Chegava em casa onze e meia, pra acordar às cinco no dia seguinte. Às vezes não tinha ônibus, é aquela arrumação. Aí meu marido ia me buscar, e saco de homem reclamando, pepe-pé, pe-pe-pé, aí eu pensava assim, entra por aqui e sai por aqui, nem ligava. É uma barra, menina. [...] Aí ele ficava o tempo todo tempo dizendo. Mas quando! Por que não estudou quando era nova? Aí eu digo: mana, tô morta não, ainda to viva, não estudei lá, mas to estudando agora. (...) Menina, ficava morta! Mas aí, né? A gente tem força de vontade, a gente vai que consegue. Nada é cansaço" (Profa. Diva).
\end{abstract}

A vida econômica gira em torno da horta, que se tornou uma alternativa ocupacional para quase todos os moradores, principalmente para os adultos. Como há razoável circulação de mão de obra nesta atividade, o trabalho assalariado é intercalado com serviços esporádicos (bicos): como caseiros, pedreiros, ajudantes e pescadores. Não se configuram como produtores rurais, e são poucos os que ainda desenvolvem a agricultura de subsistência. Observou-se aqui a presença de um contorno diferenciado de trabalho, que cada vez mais se aproxima das características de populações que habitam as margens de rodovias, ou mesmo as periferias urbanas.

A maioria das famílias recebe algum tipo de benefício, sendo a bolsa-escola o principal, seguido por pensão, aposentadoria e auxilio doença. Em alguns casos, esta é a única renda regular da família.

Os mais jovens são estimulados a procurar emprego em outras localidades, que requeira menos esforço braçal e que seja socialmente mais valorizado. Em vista disso, os pais se esforçam para que os filhos possam estudar e conseguir algum emprego público ou uma profissão especializada.

A pesca permanece como atividade de subsistência e a extração de frutos na mata como complemento alimentar, apesar de serem cada vez mais escassas. Na dieta alimentar predomina o consumo de peixe e farinha, e na maioria das residências, as hortaliças cultivadas no local de trabalho, à exceção dos temperos (chicória, coentro e cebolinha), ainda não foram introduzidas nos hábitos alimentares. 
Cada vez mais os aparelhos eletrônicos e os produtos industrializados incorporam a lista de consumos necessários, e, cada vez menos, as práticas de subsistência são desenvolvidas. Quase não há criação de animais nem cultivos domésticos, visto que os quintais são pequenos e sempre há alguém na família que trabalha na horticultura. Ainda assim, observou-se em algumas casas o canteiro de temperos e de plantas medicinais.

Esta comunidade é predominantemente evangélica, mas é comum benzer os filhos, e recorrer às benzedeiras e plantas medicinais em determinadas situações, como nos casos de "desmentidura" (quando há uma torção muscular), ou para o tratamento de enfermidades que não são curadas pelos médicos (por exemplo, ser judiado de boto). Também permanecem as relações de compadrio, e faz parte dos compromissos familiares visita ao padrinho e/ou madrinha, e tomar a bênção aos mais velhos.

Os vínculos familiares e de vizinhança podem ser considerados indicadores do modo de vida rural, pois as estratégias para buscar informações e transmitir conhecimentos estão basicamente associadas à oralidade, as relações são próximas, vizinhos se conhecem pelo nome, mantendo práticas de ajuda mútua. Há certa homogeneidade entre os vizinhos, com tênue estratificação, e grande diferença entre estes e os sitiantes.

Entretanto, cada vez mais privilegiam ocupações e práticas do mundo urbano. As relações de cooperação e de solidariedade têm sido substituídas por estratégias individuais e de prestação de serviços. Mesmo para tomar conta do sobrinho ou neto, é preciso algum pagamento. Espaços que antes eram coletivos tornam-se privatizados e atividades coletivas são cada vez menos frequentes. Quanto aos cuidados com o ambiente, observamos muito lixo e sujeira pelas ruas, trechos de ruas tomados pelo mato, torneiras e caixas d'água que derramam água enquanto a bomba do poço estiver em funcionamento. $\mathrm{O}$ discurso ecológico está presente em algumas falas, mas não se solidifica em ações.

Os moradores se ressentem da desorganização comunitária, mas não se envolvem. Por um lado, temem retaliações. Por outro, desconfiam que os diretores da associação de moradores se beneficiem em nome da comunidade. Acham que os problemas de saneamento básico, transporte e meios de comunicação (telefonia e correios) poderiam ser amenizados se a associação fosse mais participativa e procurasse resolver os problemas da comunidade. Esta participação envolve prioritariamente buscar ajuda junto a personagens da política local, pois "só com a ajuda de políticos" se conseguem benefícios, mas para isto a comunidade precisa estar organizada, e se reunir em torno de um único candidato, o que geralmente gera conflitos, pois cada morador quer apresentar o seu. 
Para os moradores a associação existe, mas não se faz presente na vida da comunidade. Conforme relato da presidente da associação, há dificuldades em manter seu funcionamento, pois faltam recursos para regularização dos documentos, falta apoio do poder público que promete e não cumpre, e dos moradores que "acham que associação é só a diretoria". Se anteriormente reuniam-se para o trabalho em mutirão, hoje "reclamam $e$ esperam que alguém faça, mas não se oferecem para ir junto ou ajudar a pagar uma passagem" (D. Carla).

\section{A Escola}

Busca-se, neste segmento, conhecer a escola, seus agentes e sua clientela. Apresentam-se sua contextualização, histórico e condições de acesso. Posteriormente, faz-se uma descrição de cenas do ambiente escolar e sua organização, sem a pretensão de esgotar todas as cenas. Estas informações foram obtidas através da análise de documentos da escola, dos registros produzidos durante o período de observação participante e através dos conteúdos das entrevistas.

\subsection{Histórico, localização e acesso}

A Escola em questão localiza-se numa comunidade rural na Amazônia, na confluência bacia hidrográfica/estrada. Foi inaugurada em dezembro de 2004, pelo Prefeito em exercício, tendo iniciado seu funcionamento em fevereiro de 2005. O nome da escola foi indicado pela diretora, em homenagem ao pai do então prefeito em exercício que, segundo a mesma, foi importante colaborador na construção desta escola e no apoio a outras escolas rurais onde trabalhou. A homologação do contrato de execução/construção da escola foi publicada no diário oficial do município em 01 de outubro de 2004, levando apenas dois meses e meio para a obra ser construída e inaugurada. A diretora está na escola desde sua inauguração, o que não ocorre com o quadro docente, técnico e de apoio. Apenas uma professora, contratada, que mora em outra comunidade no mesmo bairro, está na escola desde sua inauguração.

Apesar de ter sido inaugurada há quatro anos, não possuía ato de criação, em função de o nome da escola ter sido publicado em diário oficial em outro endereço. Somente em junho/2008, um Projeto de lei alterou na Estrutura Administrativa da Secretaria Municipal de Educação o endereço da escola. Até então, apesar de estar em funcionamento de fato, não o 
era oficialmente, o que inviabilizava a participação da escola em programas de financiamento, a criação do conselho escolar e mesmo a construção do projeto pedagógico.

A justificativa utilizada para nomear a escola é de que o senhor homenageado era um distinto homem, europeu, formado em economia e antropologia, falava vários idiomas, católico, empresário, possuindo várias lojas em um estado da região sudeste, e sócio de outras empresas. Viajante, procurava implementos para novos empreendimentos, contribuindo para o desenvolvimento econômico da cidade. Além disso, preocupava-se com questões sociais, fazendo doações para escolas, orfanatos, esportes e hospitais.

Conforme informações obtidas com a diretoria da associação comunitária, a construção da escola deve-se às reivindicações dos moradores, em particular após a criação desta associação, que alegavam a necessidade de uma escola para os filhos pequenos, na comunidade, em virtude da dificuldade de conduzi-los para a escola mais próxima, localizada na parte central do bairro (a Vila), e da falta de vagas, o que muitas vezes estimulava deixar os filhos fora da escola. Isto desencadeou uma luta penosa e paciente, com muitas idas aos órgãos públicos, além de reivindicações junto a deputados estaduais. A escola inicialmente destinava-se à Educação Infantil, mas em função da demanda, passou também a atender a primeira etapa do Ensino Fundamental.

Pode-se chegar à escola tanto por via terrestre como fluvial. O uso do transporte terrestre é o mais frequente, embora se necessite caminhar a pé desde a estrada principal, cerca de um quilômetro e meio. Para os que residem em comunidades no interior do lago, a única opção é o uso de embarcações próprias até a parte central do bairro (a Vila) e caminhar até a comunidade, ou desembarcar nas proximidades da escola, tendo que passar por dentro de terrenos alheios. Apesar de não haver nenhuma sinalização indicando onde é a escola, não é difícil chegar até lá, pois a comunidade é pequena e esta é a única construção pública no local. Há uma estrada de acesso, não pavimentada, que liga a comunidade à Vila. No período das chuvas, torna-se bastante escorregadia e esburacada, dificultando a passagem de veículos.

A escola recebe alunos de outras áreas do bairro - de comunidades no interior do lago e na estrada. Também os profissionais que lá trabalham, em sua maioria, residem em outras localidades. Apenas uma funcionária mora na comunidade, ficando, por isso, responsável por receber a chave dos vigias e abrir a escola todos os dias de manhã. Em 2008, havia 198 alunos matriculados e dois ouvintes, distribuídos em oito turmas e três turnos: três turmas no turno matutino, duas no turno intermediário e três no turno vespertino. A escola trabalha com o princípio da não-retenção, não havendo, portanto, índices significativos de reprovação. 
Houve, entretanto, grande número de ausências durante o ano letivo, em algumas turmas quase $40 \%$, que não configurou como evasão nem resultou em reprovação.

Não há disputa de vagas, mas a demanda tem crescido, principalmente em relação à Educação Infantil. Há registros significativos em relação ao aumento da clientela.

Tabela 1 - Número de alunos matriculados na escola - 2005 a 2009

\begin{tabular}{|c|c|}
\hline Ano & Total de alunos \\
\hline 2005 & 78 \\
\hline 2006 & 96 \\
\hline 2007 & 150 \\
\hline 2008 & 200 \\
\hline 2009 & 248 \\
\hline
\end{tabular}

Sendo pequena para abrigar a demanda já existente, a direção da escola tem efetuado esforços para ampliação da mesma, ou pelo menos locação/cessão de algum espaço, e informou da necessidade de permanência do turno intermediário e do uso de espaços improvisados enquanto aguarda providências.

Por ser uma escola rural, possui transporte escolar, fornecido pela Secretaria Municipal de Educação, cuja finalidade é "viabilizar o acesso e a permanência dos alunos na escola, visando contribuir para minimização dos índices de infrequência e evasão" (Histórico da escola, 2008). Entretanto, não há barco para quem reside em áreas cujo acesso é exclusivamente fluvial. Assim sendo, uma professora e alguns alunos vêm de embarcação própria até a margem do igarapé, seguindo a pé até a escola.

O que se observa é que, mais do que viabilizar acesso aos alunos, o transporte facilita a ida e vinda dos professores e técnicos, que levariam cerca de duas horas no percurso entre suas residências e a escola, caso utilizassem o transporte coletivo.

Mesmo sendo recente, a escola carrega as expectativas de melhoria de vida para os alunos, e para a comunidade. Possui uma boa referência, principalmente em relação à diretora, vista como alguém dedicada aos alunos, disponível e acolhedora, e consequentemente, acolhida pela comunidade.

\subsection{Cenas do ambiente escolar}

Nesta parte, conhece-se o espaço físico da escola. As informações abaixo descritas foram obtidas através da leitura de documentos da escola, e durante o período de observação participante. 


\section{Espaço físico}

Construída em 2004, a escola é feita em alvenaria, pintada em verde e branco, coberta de telhas de barro, sobrepostas e fixadas em armações de ferro. Possui janelas basculantes de ferro, pintados de amarelo e calhas no telhado para canalizar águas pluviais. $\mathrm{O}$ terreno da escola, ligeiramente inclinado, mede $3.500 \mathrm{~m}^{2}$, havendo aproximadamente $700 \mathrm{~m}^{2}$ de espaço construído, em um único bloco, assim subdividido: duas salas de aula, dois banheiros, um refeitório, uma cozinha, um depósito de alimentos (acesso pela cozinha), uma diretoria e um depósito de materiais de expediente (acesso pela diretoria), além de dois quartos com banheiros, para professores, localizados atrás dos dois banheiros e tendo acesso pelo lado externo à escola.

Quartos para professores foram projetados para as escolas rurais, considerando que, em virtude da distância e da acessibilidade, os professores passam a semana na comunidade onde se localiza a escola, retornando para casa somente nos finais de semana. Nesta escola, que possui acesso rodoviário e transporte oficial, e fica a aproximadamente $32 \mathrm{~km}$ do centro urbano, os profissionais que residem em outras localidades podem deslocar-se com mais facilidade, indo e vindo todos os dias. Assim sendo, um quarto é utilizado pelo vigia e o outro serve como depósito de material. O teto de todos os cômodos, à exceção do refeitório, é forrado com PVC, na cor branca. Há um espaço entre o forro e o telhado de aproximadamente $80 \mathrm{~cm}$ ao centro dos cômodos, diminuindo para aproximadamente $12 \mathrm{~cm}$ nas bordas. $\mathrm{O}$ piso da cozinha e banheiros é cerâmica branca, os demais espaços são cobertos por placas de cimento.

A escola é toda gradeada, havendo apenas uma entrada, com quatro degraus. O portão é de ferro, pintado de amarelo, ligeiramente descascado, possui dois trincos, onde são colocados cadeados. Durante o horário de funcionamento da escola, o portão fica fechado por um dos trincos, mas não trancado. Do portão de entrada segue um corredor, que dá acesso ao refeitório e demais dependências, passando primeiramente por uma saleta, onde funciona a diretoria. A escola não possui secretaria. Os quartos de professores também possuem degraus à entrada e, em virtude da inclinação do terreno, em uma delas, há quatro e na outra, dez degraus. Não há acesso aos quartos pelo interior da escola.

Diferente do padrão retangular estabelecido pela Secretaria Municipal de Educação para escolas rurais à época de sua construção, possui um refeitório em formato hexagonal, de onde se tem acesso às salas de aula, aos banheiros e à cozinha, sendo cada um destes espaços construídos a partir de uma das paredes do hexágono, deixando duas paredes abertas para o exterior. 
Este mesmo padrão oficialmente estabelecido determina que as escolas rurais possuam somente duas salas de aula, independente da demanda discente e de séries, utilizando-se ainda as classes multisseriadas. Não há outros espaços além das salas para biblioteca, laboratórios, nem sala de professor. De modo geral, as escolas rurais contam com apenas um ou dois professores, sendo um destes o responsável pela escola.

Nesta escola não há muro nem cerca. O terreno é descampado, não é cimentado, nem gramado, deixando um grande espaço aberto, em terra batida, onde carros aproveitam para fazer o contorno, ou acessam a rua que passa atrás da escola, haja vista que a rua lateral que permite este acesso está coberta de mato e cheia de valas, em função da água servida e pluvial que empoçam e escorrem a céu aberto, descendo para alcançar a margem do igarapé.

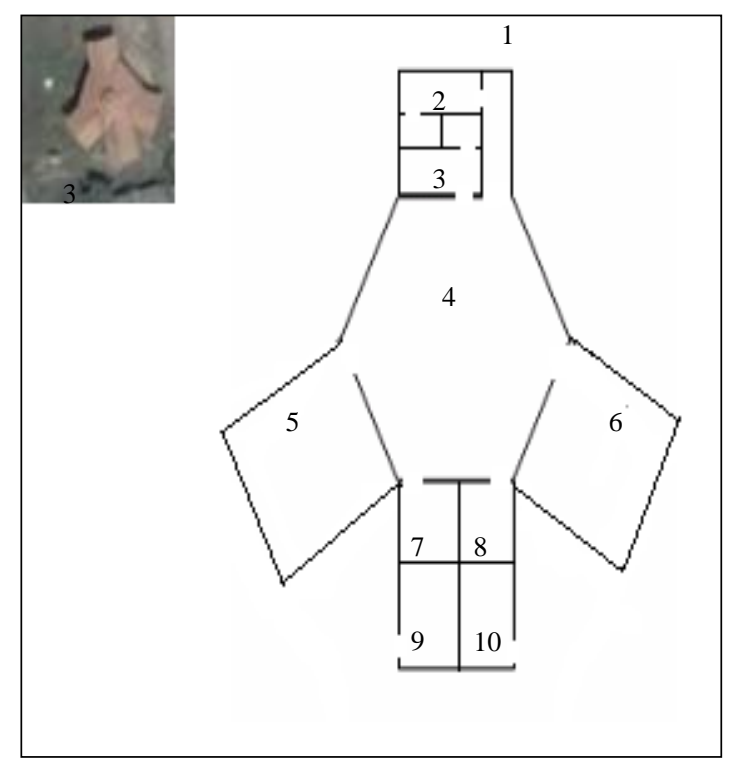

Figura 1 - Demonstrativo de planta da escola

\begin{tabular}{|c|c|}
\hline \multicolumn{2}{|l|}{ Legenda: } \\
\hline 1) Portão de Entrada & 2) Diretoria \\
\hline 3) Cozinha & 4) Refeitório \\
\hline 5) Sala 01 & 6) Sala 02 \\
\hline 7)Banheiro Feminino & 8) Banheiro Masculino \\
\hline \multicolumn{2}{|c|}{ 9) Quarto de professor (utilizado como depósito) } \\
\hline 10) Quarto de professo & izado pelos vigias) \\
\hline
\end{tabular}

Não há nenhuma plantação no terreno, além de duas árvores (cajueiro e goiabeira) próximas ao prédio, entre este e a rua, que cresceram aleatoriamente. Não há também espaços privados, além da própria sala de aula, para os professores, a cozinha, para a merendeira, (e a 
sombra de uma árvore na casa do vizinho, para o motorista). Os professores, quando não estão em sala de aula, dispõem do refeitório.

As salas, banheiros, cozinha e diretoria possuem portas em tamanho padrão, ou seja, cerca de oitenta centímetros. Não há rampa para entrar na escola nem nos quartos, o que dificulta o acesso a cadeirantes e/ou pessoas com dificuldade de locomoção. A escola não apresenta condições adequadas para o atendimento de alunos com necessidades educativas especiais, sem rampas, sem banheiros e sem mobiliário específicos a este uso.

A decoração dos ambientes é feita pelos professores e pela diretora, que colabora com o trabalho realizando pesquisas de temas, textos, poesias e figuras na internet e outras fontes. Há um tema geral para cada ano letivo. Este tema é escolhido pela diretora em acordo com os professores, e deve figurar em todos os eventos e documentos. Em 2005, o tema foi Smilinguido; em 2006, a turma do Mickey; em 2007, o ursinho Poof; em 2008, novamente o Smilinguido; para 2009, o piu-piu e a turma do Looney Tones.

Observou-se, em relação à ornamentação, que não houve participação nem produção dos alunos, ou seja, não se observou nenhum desenho ou cartaz produzido pelos alunos como parte da ornamentação da escola, a não ser nos varais em sala de aula, e em dois momentos específicos: por ocasião do Dia das Mães e durante a Semana do Meio Ambiente, durante a qual uma professora expôs cartazes produzidos por alunos de outra escola. Também se constatou que os professores recém-chegados não adotaram o uso da figura-tema, que apareceu apenas nas atividades realizadas pelas professoras anteriores.

A escola não possui condições artificiais adequadas de aclimatação, contando apenas com dois ventiladores velhos e ruidosos em cada sala de aula e no refeitório, que não asseguram conforto necessário nos dias quentes entre julho e novembro. Sua localização na parte alta do terreno descampado, e próxima aos igarapés e a áreas ainda florestadas, permite receber os ventos que atravessam a terra firme, tornando alguns dias bastante agradáveis. Entretanto, durante a seca, os dias quentes e úmidos são bastante desconfortáveis e sugerem que a elevação da temperatura decorrente do esgotamento ambiental já se verifica nestas localidades. O telhado alto também auxilia na minimização do calor, permitindo ventilação. Em setembro/2008, pouco antes das eleições municipais, chegaram à escola três aparelhos de ar condicionado, modelo split, e logo em seguida uma equipe foi preparar a instalação elétrica. Entretanto, a equipe responsável por instalar os equipamentos não compareceu e, pelo menos até maio/2009, não haviam sido instalados.

As instalações elétricas permanecem em bom estado de conservação, havendo disponibilidade de tomadas em todos os cômodos. Há também boa iluminação, apesar de 
poucos interruptores, fazendo com que haja grande gasto de energia, pois ao acender uma lâmpada de um cômodo, acendem-se todas as outras. No refeitório, por exemplo, são 24 lâmpadas fluorescentes, em 12 calhas grandes.

Para o abastecimento de água, a escola conta com um poço artesiano, que foi construído por solicitação da associação comunitária a uma organização filantrópica vinculada a uma ordem religiosa católica, para o abastecimento da comunidade. A associação também havia solicitado a construção de um poço à Prefeitura da cidade. Havendo dois poços, e um deles construído no terreno da escola, a Associação Comunitária procedeu à cessão deste. Há uma caixa d'água que recebe e distribui a água exclusivamente para a escola. Parte do encanamento que sai da caixa d'água para o interior da escola encontra-se exposto, mas não há vazamentos. As instalações hidráulicas estão conservadas, apresentando apenas um vazamento no bebedouro, que escorre para um ralo e desce pela parede do alicerce, pelo lado de fora, pois deste lado, o terreno é mais inclinado.

Há fossa séptica, para onde são destinados os dejetos e a água servida dos banheiros e da cozinha, desta após passar por uma caixa de gordura. Há uma rachadura no cano que sai desta caixa, deixando parte da água servida a escorrer a céu aberto pelo terreno da escola, alimentando o mato e sendo absorvida ainda dentro do próprio terreno. As águas pluviais também são canalizadas, descendo por dutos de $100 \mathrm{~mm}$ até caixas, onde são absorvidas pelo solo. Um dos canos também está quebrado.

Quanto à limpeza e conservação, a escola possui três funcionários, um em cada turno. Apesar disso, as paredes são sujas, há carteiras riscadas e muita poeira em cima dos armários. O espaço acima das salas de aula e da cozinha, entre o teto das mesmas e o telhado, aparenta nunca ter sido limpo, guardando bastante poeira, e teias de aranhas que servem de reserva de alimentos para alguns passarinhos oportunistas, dentre eles, os canários, que de vez em quando dominam a atenção de quem observa. O quarto de professor que serve como depósito de material está completamente empoeirado e cheirando a mofo.

Mas, de modo geral, a escola apresenta bom estado de conservação, necessitando de pintura, reposição de algumas lâmpadas, manutenção e reforma em partes do telhado, sobre as salas de aula e refeitório, onde persistem vazamentos em seis locais. Houve um conserto no telhado em fins de 2008, feito através de contrato terceirizado; todavia, o problema não foi totalmente resolvido, restando ainda as supramencionadas goteiras. $\mathrm{O}$ profissional contratado informou que seria necessário refazer boa parte do telhado, pois a troca de telhas isoladas acaba retirando outras do lugar, provocando novos vazamentos. 
O edifício foi planejado para abrigar exclusivamente a Educação Infantil, considerando que há outras escolas em localidades próximas, rurais e urbanas, destinadas ao Ensino Fundamental. Todavia, sob responsabilidade da direção da escola, tem atendido desde o Ensino Fundamental até a $3^{\text {a }}$ série, considerando demanda identificada e comprovada pela matrícula e lista de espera. Em 2008, não houve possibilidade de atender parte da clientela da Educação Infantil, especificamente os alunos de quatro anos, por falta de espaço físico. Decidiu-se privilegiar as séries de ensino obrigatório, ou seja, acima de seis anos. Também em função desta demanda, tem sido necessário utilizar parte do refeitório como sala de aula. A escola, portanto, não apresenta espaço suficiente para abrigar alunos em condições adequadas.

Após dois anos de reivindicações, documentos e luta pela ampliação do espaço construído, a administração municipal atendeu e encaminhou deliberação de licitação para se ampliar a escola em fevereiro/2009. Apesar disso, não houve nenhuma ampliação ou reforma até julho de 2010.

\section{O corredor}

Medindo 1,00 X 5,00m, é via de circulação que, passando pela diretoria, dá acesso ao refeitório e demais dependências. O lado esquerdo é gradeado, e na parede do lado direito encontram-se a placa de identificação da escola, a porta de entrada da diretoria, o basculante do depósito de alimentos e um espaço destinado ao Mural da escola. Este espaço está organizado de modo a permitir dois murais: O primeiro, medindo $1 \mathrm{X} 1 \mathrm{~m}$ e localizado embaixo do basculante, manteve-se o mesmo por todo o primeiro semestre letivo. Feito em emborrachado colorido e ornamentado com desenhos de flores, trazia a palavra escola na diagonal, formando novas palavras a partir de cada letra:

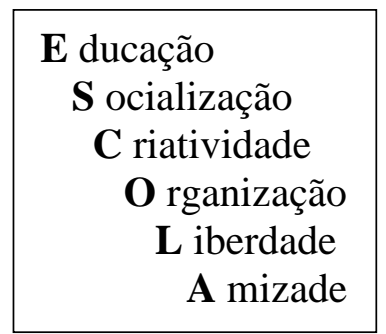

Figura 2 - Mural de apresentação da escola. 
No segundo semestre, este cartaz foi substituído por ocasião do Dia da Devolução do Livro Didático, e posteriormente a colocação de avisos esporádicos. O segundo mural, denominado mural informativo e medindo $1,00 \times 2,60 \mathrm{~m}$ foi continuamente modificado, em função das datas comemorativas ou algum ponto relativo aos projetos desenvolvidos pela escola. Em maio, referia-se ao Dia das Mães, o início do mês de junho compôs ecologia e meio ambiente, e no fim do mês apresentou a festa junina. Em julho, referia-se ao retorno das atividades escolares e a devolução do livro didático. Por ocasião do Dia da Avó, o mural foi novamente composto. Apesar de ser considerada uma data importante para a escola, este mural só foi preparado nas vésperas do evento. Durante os meses de agosto e setembro o mural ficou em branco. Em outubro, apenas um pequeno cartaz informava o Dia das Crianças. Em novembro, o espaço foi destinado a cartazes informativos sobre atividades na escola ou ausência de professores e diretora. E somente em dezembro, para comemoração do Dia da Família, o mural foi ornamentado, fechando com o encerramento do ano letivo.

\section{A diretoria}

É a primeira sala, ao entrar na escola, um espaço medindo aproximadamente $4,5 \mathrm{~m}^{2}$, com um cômodo anexo, de $1,5 \mathrm{~m}^{2}$, denominado depósito de material de expediente. A escola não possui secretaria, e isto é enfatizado pela direção da escola. O espaço da diretoria é mínimo, não cabendo mais que duas ou três pessoas. A porta permanece aberta quando a diretora está na escola. Em sua ausência, a professora de apoio e a funcionária tomam o cuidado de mantê-la fechada quando saem para o refeitório ou outro local.

Quanto ao mobiliário, há duas mesas de escritório, feitas em armação de ferro e tampo em MDF cinza, medindo 1,20m X 0,65m e 0,90 X 0,60m, com computadores e papéis; uma estante pequena de madeira com material escolar e livros didáticos para consultas amontoados em suas quatro prateleiras; um armário de ferro em cor cinza contendo caixas-arquivo com documentos dos alunos e da escola; um arquivo de quatro gavetas, cinza, também para documentos, material de expediente e escolar. Os móveis estavam dispostos encostados à parede, deixando um pequeno vão no centro da sala. Até outubro, havia somente um computador. A outra mesa destinava-se a uma funcionária para atendimento e trabalhos administrativos. $\mathrm{O}$ outro computador foi adquirido em novembro, com recursos do conselho escolar. Houve então reorganização do espaço, utilizando o armário de ferro para dividir a sala em dois ambientes, um para a diretora, na parte posterior da sala, onde fica uma mesa e o computador recém adquirido, e outro à frente, com o computador antigo, para uso dos professores e da funcionária. 
Sobra apenas uma parte de parede livre, junto à porta, onde estão afixados dois cartazes: um do tamanho de uma folha de cartolina, e feito com os motivos-tema do ano, o "Smilinguido", contém datas de aniversário dos profissionais; outro, do feito em papel A4, configuração paisagem, possui uma tabela com os dias da semana em que cada professor deve acompanhar o transporte escolar. A partir do segundo semestre, um pequeno painel, feito em emborrachado verde e intitulado "Mensagem da semana" foi afixado na porta. Foi produzido pela diretora e nele foram afixadas algumas mensagens, impressas em folha de papel ofício, e substituídas inicialmente toda semana, depois mais espaçadamente.

Na sala anexa, denominada "depósito de material de expediente", há uma estante de ferro, com cinco prateleiras onde se localiza o arquivo morto. Também estão guardados o material escolar e de expediente, e os equipamentos audiovisuais. A escola possui uma televisão 20 polegadas, um dvd modelo antigo e um toca cds portátil, marca JWIN, em precárias condições de funcionamento. Há também uma coleção de vídeos do Programa TV Escola, e cd's e dvd's, estes adquiridos com recursos pessoais da diretora e doações de professores. Para realização de eventos, a escola conta com o empréstimo de uma caixa amplificada e um microfone, feito por pai de um aluno, que pega emprestado no sítio onde trabalha como caseiro.

Os equipamentos ficam guardados sob responsabilidade da diretora. O uso é acessível a qualquer professor ou mesmo funcionário, desde que para uso didático, solicitando o equipamento à diretora e, quando esta não está na escola, com a professora de apoio ou a auxiliar que trabalha como agente operacional. Não há agendamento para este uso, haja vista sua pouca utilização. Os professores combinam o uso. É regra que todo equipamento danificado deve ser guardado para prestação de contas, e posteriormente incinerado. A escola ainda não possui equipamentos danificados, mas quase. Necessita com urgência, de novos equipamentos.

\section{As salas de aula}

Há duas salas de aula. Medindo $56 \mathrm{~m}^{2}$, localizam-se na área oposta à entrada da escola, com porta para o refeitório, sendo a sala 01 localizada no lado direito e a sala 02 , localizada no lado esquerdo. Há boa acústica e vedação de som. Em cada sala de aula há duas paredes com basculantes, uma delas voltada para o refeitório e a outra para a rua. De modo geral, as janelas voltadas para o refeitório permanecem fechadas. As janelas da sala 01 dão visibilidade para o terreno da escola e para os sítios às margens do igarapé, ficando abertas. As janelas da 
sala 02 localizam-se próximas à rua, estando parcialmente fechadas por causa de um painel nelas afixado e da poeira que se levanta com a passagem de carros.

As paredes são recobertas com azulejos quadriculados, na cor cinza, até a altura de $1,50 \mathrm{~m}$, onde corre uma ripa de madeira, pintada de amarelo, ali instalada objetivando a fixação de cartazes e trabalhos, considerando a determinação da Secretaria de Educação de não mais fixar cartazes nas paredes. Apesar desta proibição, a direção da escola assume a responsabilidade de colar painéis e cartazes nas paredes, argumentando a necessidade dos mesmos, a inadequação e precariedade deste corrimão de madeira e a ausência de murais onde se pudesse fixá-los. Uma terceira sala foi improvisada no refeitório, próxima à entrada dos banheiros. Ao contrário das anteriores, possui várias inadequações. As salas de aula são ocupadas pelas séries, conforme quadro abaixo:

\begin{tabular}{|c|c|c|c|}
\hline Horário & Sala 01 & Sala 02 & Sala no refeitório \\
\hline Matutino & $2^{\mathrm{a}}$ série & $2^{\mathbf{o}}$ ano $($ ciclo) & $1^{\mathbf{a}}$ série \\
\hline Intermediário & $3^{\mathrm{a}}$ série & $1^{\mathbf{o}}$ ano $($ ciclo) & -- \\
\hline Vespertino & $3^{\mathrm{a}}$ série & $2^{\mathbf{o}}$ período $(\mathrm{EI})$ & $2^{\mathrm{a}}$ série \\
\hline
\end{tabular}

Quadro 2 - Descrição da ocupação de salas de aula

As salas de aula apresentam o padrão típico das escolas do município. A sala de aula 01 possui em torno de trinta carteiras individuais com braço, feitas em armação de ferro, com suporte inferior para guardar materiais, com assento, encosto e apoio de plástico na cor azul marinho, organizadas em cinco colunas geralmente desalinhadas; mesa para professor, pequena, armação de ferro e tampo de MDF na cor cinza; um armário de ferro cor cinza, um arquivo com quatro gavetas, uma estante de madeira com caixas, revistas velhas e livros usados, um quadro branco. Dois ventiladores de parede afixados um ao lado esquerdo do quadro branco, acima da mesa do professor e outro na parede detrás, na direção diametralmente oposta, não são suficientes para promover adequada ventilação nos dias quentes.

A ornamentação foi feita pelas professoras que iniciaram o ano letivo, trazendo os motivos-tema do ano. O professor que assumiu a partir do mês de abril não fez nenhuma modificação. À porta, um cartaz desbotado diz "sejam bem vindos”. Um painel ocupa quase toda a parede do fundo da sala, onde figurinhas Smilinguidas seguram sorridentes as letras do alfabeto ao alto de suas cabeças. Ao centro, um cartaz com Smilingüidos flutuando em um jardim de flores e arco-íris, traz os dizeres: "eu não posso ensinar nada a ninguém, só podemos fazê-lo pensar". Um barbante esticado junto à parede dos fundos e outro junto aos 
basculantes, funcionam como varal para trabalhos produzidos pelos alunos. À frente, ao lado direito do quadro branco, um cartaz, já desbotado e borrado em virtude de uma goteira que escorre pela parede, traz as regras da sala: o "cartaz de combinados". Este cartaz, conforme esclarecido por uma professora, foi feito em conjunto com os alunos da $3^{\mathrm{a}}$ série, no início do ano letivo, procurando escrever as regras que poderiam favorecer o bom andamento dos trabalhos em sala de aula. Conforme depoimento dos alunos, o cartaz foi feito pela professora. Dita as regras: não sujar, não fazer bagunça, não às conversas paralelas, não brigar, não bagunçar (de novo), não sujar (de novo), não...!

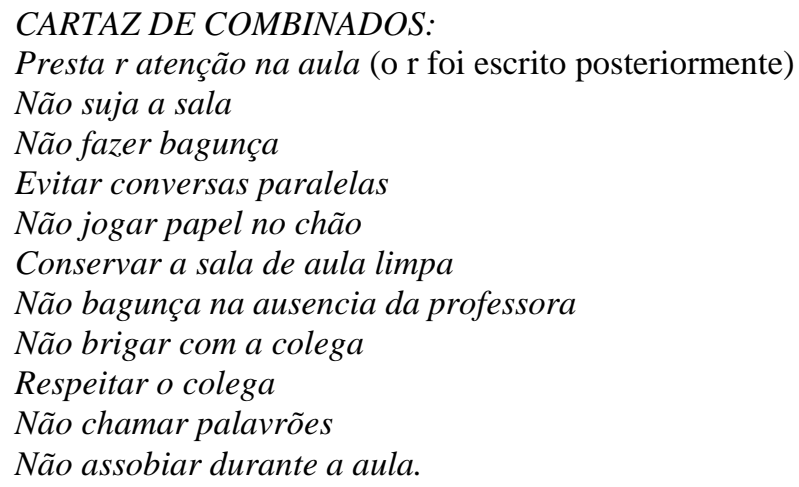

Figura 3 - Cartaz de combinados

À porta da sala de aula 02 um convite ao estudo: "Feliz volta às aulas". Possui nove mesinhas para Educação Infantil, com quatro cadeiras cada, dispostas duas a duas; uma mesa pequena para professor; dois arquivos com quatro gavetas; duas estantes de madeira com cadernos dos alunos em uso e outros em desuso, alguns livros didáticos e material escolar em uso, tipo lápis de cor, lápis cera, borrachas, carimbos, tintas, canetinhas, colas coloridas, guardados em potes plásticos e caixas; uma mesa com um microcomputador; uma estante de madeira feita com seis caixotes deitados de lado e sem o fundo, dispostos três em cima de outros três, juntos, imitando uma casa de bonecas, com duas folhas de isopor por cima, justapostas em forma de "V" invertido, caracterizando o telhado, denominada brinquedoteca. Cada caixote foi encapado com papéis nas cores azul, vermelha e amarela, estando desbotados, descolando e rasgados. Os brinquedos são velhos, mas a maioria está conservada. Há onze bonecas, seis carrinhos, um bichinho de pelúcia e dois pedaços de brinquedos para uso com carrinhos, tipo uma rampa circular por onde carrinhos descem. Há também algumas carteiras, encostadas nas duas paredes laterais da sala, abaixo dos basculantes, e vinte cones de trânsito, que ficam guardados, no canto direito ao fundo da sala. Dois ventiladores, um ao 
lado direito do quadro branco e outro ao fundo, fazem a circulação do vento, precária nos dias mais quentes.

As paredes foram ornamentadas pela professora que utilizava a sala, no início do ano letivo. Há um painel ocupando metade da parede, afixado nos basculantes, com o tema do ano: Smilingüido. Há também um painel ao lado direito do quadro branco, do projeto "Vila do ABC", construído pela professora juntamente com a diretora. Este painel, no segundo semestre letivo, permaneceu apenas como ornamento, em virtude de não ter havido continuidade na execução do referido projeto. Trabalhos dos alunos são fixados em um varal esticado à frente dos basculantes. Não parece haver proibições oficiais quanto à possibilidade de os alunos participarem da ornamentação da escola, todavia esta não foi utilizada como estratégia em nenhum momento.

Não há, nas salas, espaços privados para os alunos guardarem seus materiais. Cada aluno permanece com seu material junto à carteira em que está sentado. Alguns alunos mantêm um padrão de assento, ou seja, sentam-se todos os dias no mesmo lugar, mas há outros que circulam. A sala 02 é destinada à educação infantil, e a sala 01 para turmas em que os alunos se encontram dentro da relação idade-série, ficando no refeitório a $1^{\mathrm{a}}$ e $2^{\mathrm{a}}$ série, onde foram matriculados os alunos repetentes.

\section{O refeitório}

O refeitório é o principal espaço de circulação e convívio da escola, utilizado por todos para várias atividades. É por ele que se tem acesso à cozinha, aos banheiros, às salas de aula e destas, ao corredor que conduz à diretoria e a entrada/saída da escola. Em formato hexagonal, e medindo aproximadamente $100 \mathrm{~m}^{2}$, possui duas paredes construídas em alvenaria até a altura de aproximadamente $1,10 \mathrm{~m}$, com basculantes de ferro até o alto na divisão com as salas de aula, uma parede entre estas na divisão com os banheiros, e do outro lado, duas paredes com grades, permitindo visibilidade para o lado externo e, entre estas, a parede onde se encontra a saída para o corredor, e a porta e o balcão da cozinha. Duas latas de lixo grandes também ficam no refeitório, próximas ao corredor.

Quanto ao mobiliário, o refeitório possui três mesas com bancos acoplados, feitos em armação de ferro e tampo de aglomerado coberto com fórmica branca, que são utilizadas para servir as merendas, mas também para quaisquer outras atividades, como reuniões, recepção de visitas, planejamento e preparo de material. Localizam-se uma à frente da cozinha, as outras próximas às grades, uma do lado esquerdo e a outra do lado direito. Há um bebedouro elétrico 
de ferro, em cor branca, da marca IBBL, com três torneiras e quatro boquinhas, localizado próximo ao balcão da cozinha, fixado na parede, abaixo da grade.

Uma sala de aula foi improvisada na parte do refeitório oposta à entrada e à cozinha, no intervalo entre as salas de aula, à frente dos banheiros, visando atender a duas turmas, $1^{\mathrm{a}}$ série no horário matutino e $2^{\mathrm{a}}$ série no horário vespertino, em função da demanda de alunos.

Configurando o espaço de sala de aula, há dezesseis carteiras, que são organizadas em quatro filas, para as aulas do horário matutino, e em semicírculo, ou melhor, três lados de um retângulo, para o horário vespertino. Ao fundo, um quadro branco preso à parede, localizado entre as duas portas dos banheiros masculino, à esquerda, e feminino, à direita. À frente do quadro, uma pequena carteira funciona como mesa do professor. Acima dele, uma faixa traz a missão da escola: MISSÃO: Promover o ensino da língua materna de modo a introduzir o aluno no mundo da escrita, tornando-o um cidadão funcionalmente letrado, garantindo o domínio da linguagem, necessário para o exercício da cidadania.

Encostado à parede junto à Sala 01 há um arquivo de ferro com quatro gavetas, utilizado para guardar material do professor e da escola, dez carteiras dispostas em duas filas, e sem espaço entre as mesmas, um quadro branco, usado para afixar painéis e cartazes e um suporte para álbum seriado, encostados por trás das carteiras. Os basculantes desta parede são frequentemente utilizados para afixação de cartazes e painéis, conforme as datas comemorativas e festividades da escola. O quadro branco foi colocado no refeitório a partir de agosto, por solicitação do professor da $1^{\text {a }}$ série, para ser utilizado como mural da sala de aula, ora ficando em cima de algumas carteiras, ora no chão. Este mural é organizado pelo próprio professor para apoio às atividades pedagógicas. Em dezembro/2008 foi retirado e guardado no depósito. As condições de sala de aula são precárias: o quadro branco está localizado no intervalo entre as portas dos banheiros; sofre os impactos dos ruídos externos e internos à escola; poeira dos carros; circulação de alunos, funcionários e visitantes, com permanência de pessoas no refeitório; chuvas (de vento) e sol (no horário vespertino), que entram pelas grades; tiritar e fezes dos passarinhos. Não há privacidade, nem acomodações adequadas.

Configurando um espaço de apoio ao professor, há encostado à parede junto à sala 02 , um armário de ferro, servindo como guarda-volumes, com dezesseis compartimentos, adquirido em julho/2008, por solicitação dos professores, que necessitavam de um espaço para guardar pertences e material didático; duas pequenas estantes de madeira, onde se guarda o mimeógrafo e algumas caixas arquivo de plástico, que permaneceram muito empoeiradas durante todo o ano. Nestas caixas há livros didáticos velhos, revistas e jornais, usados para deles recortar figuras. 
No alto desta parede, acima dos basculantes, vinte e dois quadros no tamanho A-4, encontram-se dispostos conforme diagrama abaixo. A ornamentação deste espaço foi produzida pela diretora da escola. Contêm os seguintes dizeres (da esquerda para a direita, o primeiro em cima, o segundo em baixo, o terceiro em cima, e assim sucessivamente):

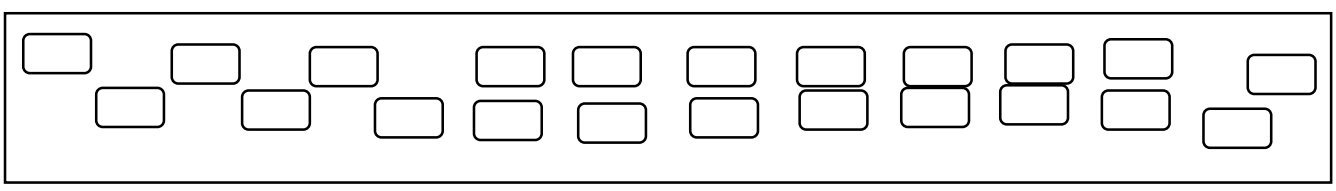

$\underline{1^{\circ} \text { Quadro }}$

Permita o erro

Chefes que fazem escândalos a cada erro que descobrem, jamais terão como funcionários pessoas pró-ativas.

$\underline{2^{\circ} \text { Quadro }}$

É melhor estar preparado para uma oportunidade e não ter nenhuma do que ter a oportunidade e não estar preparado (...)

$\underline{3^{\circ} \text { Quadro }}$

Só não erra quem não faz. $O$ desenvolvimento e a aprendizagem ocorrem muito mais através da análise dos nossos erros do que pelo louvor de nossos acertos. É preciso ter coragem de errar.

$\underline{4^{\circ} \text { Quadro }}$

Sonhe alto.

Imaginar-se vencendo todos os obstáculos durante a caminhada profissional é ingrediente fundamental para o sucesso.

$\underline{5^{\circ} \text { Quadro }}$

Não faça da sua vida um rascunho, pois pode não dar tempo de passar a limpo.

$\sigma^{\circ}$ Quadro (encontra-se desbotado)

(foto de um cãozinho branco peludo, segurando pelo talo uma folha marrom do tamanho de sua cabeça).

$O$ sorriso é a manifestação dos lábios quando os olhos encontram o que o coração procura.

$7^{\circ}$ Quadro (encontra-se desbotado)

(foto de uma garça, dentro de um córrego raso, de costas com as asas abertas).

A franqueza não consiste em dizer tudo o que se pensa, mas em pensar tudo o que se diz. (Victor Hugo)

$\underline{g^{\circ} \text { Quadro }}$

Quem não aprende com os pais o mundo ensina (Albino da S. Costa)

$\underline{9^{\circ} \text { Quadro }}$

Não chore pelas coisas terem terminado. Sorria porque elas existiram (L.E. Boudakian)

$\underline{10^{\circ} \text { Quadro }}$

(foto de caule de uma árvore, com folhagens e flores junto).

A paciência é uma árvore de raiz amarga, mas de frutos muito doces. (Aforismo Persa)

$\underline{11^{\circ} \text { Quadro }}$ 
(foto de céu escuro com estrelas brilhantes).

A mais escura da noite é justamente aquela que nos permite ver melhor as estrelas . (Charles A. Beard)

\section{$\underline{12^{\circ} \text { Quadro }}$}

... A vida só pode ser compreendida olhando-se para trás, mas só pode ser vivida olhando-se para frente!...

$\underline{13^{\circ} \text { Quadro }}$

Eduquem-se os meninos... E não será preciso castigar os homens (Pitágoras)

$14^{\circ}$ Quadro(encontra-se desbotado)

(foto de um cachorrinho peludo, de olhos grandes, deitado).

A cada minuto que passamos com raiva, perdemos sessenta felizes segundos. (William Somerset Maugham)

$15^{\circ}$ Quadro (encontra-se desbotado)

(foto de uma escada)

A gente não se liberta de um hábito atirando-o pela janela, é preciso fazê-lo descer a escada degrau por degrau. (MarkTwain)

$16^{\circ}$ Quadro

Somos o que fazemos, mas somos principalmente, o que fazemos para mudar o que somos. (Eduardo Galeano)

$\underline{17^{\circ} \text { Quadro }}$

O caos do inverno é responsável pelas flores da primavera.

$18^{\circ}$ Quadro (encontra-se desbotado)

(foto de nuvens)

A árvore não prova a doçura dos próprios frutos; o rio não bebe suas próprias ondas; as nuvens não despejam água sobre si mesmas. A força dos bons deve ser usada para benefício de todos (sábios hindus)

$19^{\circ}$ Quadro (encontra-se desbotado)

(um cãozinho dormindo em cima de botas)

A chave do sucesso é reservar 8 horas por dia para o trabalho, 8 para dormir, e ter certeza de que não são as mesmas. (Roberto Dualibi)

$\underline{20^{\circ} \text { Quadro }}$

Quando dizes: "É impossível..." Deus te diz: "Tudo é possível". $\underline{21^{\circ} \text { Quadro }}$

(foto de dois flamingos em pé dentro d'água, com o pescoço virado para baixo e o alto da cabeça encostando na água)

A humildade é uma coisa estranha... no momento em que achamos que a temos... já a perdemos.

$22^{\circ}$ Quadro (desfeita a tinta no centro do escrito, em virtude da água da chuva que escorreu de uma goteira) (desenho de dois olhos femininos azuis)

A a... não teria

Nenhum arco-íris

Se os olhos não

Pudessem la.... [não dá para ler]

Estes cartazes, juntamente com a faixa contendo a missão da escola, foram retirados no início do ano 2009, para nova ornamentação. 


\section{A cozinha}

A cozinha mede apenas $7,5 \mathrm{~m}^{2}$. Muito pequena e pouco ventilada, possui paredes recobertas com azulejos brancos até a altura de 1,60m, um basculante acima de uma pia com duas torneiras, um balcão gradeado, que dá acesso ao refeitório, para distribuição da merenda. As paredes possuem como decoração desenhos de frutas, feitos em emborrachado nas cores verde, amarelo e vermelho. Há somente uma cozinheira gerindo seu funcionamento em horário integral. Em relação ao mobiliário, há um armário de ferro, onde se guardam pratos, canecas, talheres, todos de plástico na cor azul marinho, panelas e outros utensílios de alumínio, além de mantimentos e temperos comprados pelos professores para suas refeições; um freezer com capacidade para quatrocentos litros; um fogão industrial de seis bocas e uma mesa pequena embaixo do balcão.

À porta, um cartaz informa os limites: "não entre sem permissão". Há restrições para circulação de pessoas na cozinha em função dos cuidados de higiene; entretanto, professores e auxiliares de serviços gerais também entram, ora para ajudar a preparar e servir a merenda dos alunos, ora para preparar o almoço dos professores. Na ausência da merendeira, as auxiliares de serviços gerais ficam responsáveis pela limpeza da escola, e pelo preparo e distribuição da merenda.

Da cozinha se tem acesso ao depósito de alimentos, um cômodo de $2 \mathrm{~m}^{2}$, com uma estante de prateleiras feitas em madeira, para armazenar alimentos destinados à merenda escolar. Não há cantina nem vendedores ambulantes à porta da escola.

\section{Os banheiros}

Há dois banheiros, um masculino e outro feminino. Possuem a mesma configuração, contendo de um lado o corredor com uma pia, e do outro lado, dois boxes com sanitários e um box para chuveiro. O espaço é estreito, cada box mede aproximadamente $1 \mathrm{~m}^{2}$. Todos os boxes possuem portas, com trancas simples. A pia possui duas cubas e duas torneiras, em funcionamento. Há um espelho fixado na parede acima da pia, e uma balde como lixeira embaixo dela. O papel higiênico fica no banheiro, um rolo grande fixado na parede, acima e ao lado da pia, entre esta e a porta. Geralmente há uma pequena barra de sabão à disposição para lavar as mãos, e toalhas de papel. Quando não há toalhas, utiliza-se o papel higiênico. No início do ano, havia sabonete líquido, mas o suporte quebrou, e não houve reposição.

Os banheiros são lavados diariamente, e mantém-se a limpeza durante o dia, com a passagem de um pano de chão e água sanitária, algumas vezes um desodorizador. Os banheiros não são cheirosos, mas também não há odores intensos. 
É no banheiro, no box do chuveiro, que se guardam material de limpeza, vassouras, rodo, baldes, panos de chão e produtos em uso. Não há banheiros separados para professores e funcionários, que utilizam os mesmos dos alunos. Não há vasos sanitários pequenos adequados a alunos de Educação Infantil, não há espaço para circulação de cadeiras de rodas e não estão equipados para uso de deficientes físicos. Para a limpeza dos espaços utiliza-se basicamente água sanitária.

\section{O depósito}

Um dos quartos de professor foi transformado em depósito. Localizado por trás dos banheiros, o acesso a estes quartos dá-se por fora da escola. Neste, encontra-se, em estado bastante desorganizado, documentos do tipo correspondências recebidas e informativos, livros didáticos fora de circulação, painéis e cartazes velhos, sobras de material, sucatas, brinquedos pedagógicos, algum material didático, como, por exemplo, folhas de cartolina, cartonado, emborrachado, entre outros materiais, tudo amontoado, num espaço físico improvisado, impróprio, empoeirado e mofado. Há alguns instrumentos musicais para fanfarra, que ainda não foram utilizados.

\subsection{Os Agentes institucionais}

Nesta parte, faz-se uma descrição dos agentes institucionais. Destacam-se, em alguns momentos, a título de ilustração, as falas dos próprios agentes. Os dados foram obtidos durante o período de observação participante, nas conversas durante o café, nos intervalos ou nos percursos de ônibus, e nas entrevistas. Dados que emergiram no período de observação foram complementados e mesmo confirmados com informações obtidas durante as entrevistas.

A equipe técnico-docente da escola é composta por um diretor, cinco professores, uma merendeira, quatro auxiliares de serviços gerais, sendo um deslocado de função, atuando como agente operacional para apoio à diretoria, dois vigias e um motorista. A maioria é do sexo feminino, com idades variando entre 25 e 59 anos. 


\begin{tabular}{|c|c|c|c|c|c|}
\hline Pseudônimo & Idade & Função/Cargo & Formação & $\begin{array}{c}\text { Tempo de trabalho } \\
\text { na escola }\end{array}$ & $\begin{array}{c}\text { Vínculo e } \\
\text { regime de } \\
\text { trabalho }\end{array}$ \\
\hline Maria & 44 & Merendeira & $\begin{array}{c}\text { Ensino } \\
\text { Fundamental } \\
\text { incompleto }\end{array}$ & 1 ano & $\begin{array}{c}\text { Serviço } \\
\text { terceirizado } \\
40 \text { horas }\end{array}$ \\
\hline Jane & 47 & $\begin{array}{c}\text { Agente } \\
\text { operacional }\end{array}$ & Ensino médio & 3 anos & $\begin{array}{c}\text { Contrato direto } \\
\text { com SME }\end{array}$ \\
\hline Ednelza & 25 & $\begin{array}{c}\text { Auxiliar de } \\
\text { serviços gerais }\end{array}$ & $\begin{array}{c}\text { Ensino médio } \\
\text { incompleto }\end{array}$ & 1 ano & $\begin{array}{c}\text { Contrato direto } \\
\text { com SME }\end{array}$ \\
\hline Roseli & 52 & $\begin{array}{c}\text { Auxiliar de } \\
\text { serviços gerais }\end{array}$ & $\begin{array}{c}\text { Ensino } \\
\text { Fundamental }\end{array}$ & 1 ano & $\begin{array}{c}\text { Contrato direto } \\
\text { com SME }\end{array}$ \\
\hline Manoel & 44 & $\begin{array}{c}\text { Auxiliar de } \\
\text { serviços gerais }\end{array}$ & Ensino Médio & 2 anos & $\begin{array}{c}\text { Concurso } \\
\text { publico }\end{array}$ \\
\hline Valmir & 48 & Motorista & Ensino médio & 7 meses & $\begin{array}{c}\text { Serviço } \\
\text { terceirizado }\end{array}$ \\
\hline
\end{tabular}

Quadro 3 - Descrição dos funcionários da escola em 2008.

Há duas categorias de profissionais: concursados e contratados. Dentre os professores, um é contratado e os demais são concursados. Quanto aos funcionários, um é concursado e os demais são contratados. Dentre estes, há os que são diretamente contratados pela Secretaria Municipal de Educação - os auxiliares de serviços gerais, e os que são contratados por empresas terceirizadas, como é o caso da merendeira, do motorista e vigias.

Em relação à carga horária, há entre os professores, dois tipos de concurso: 20 e 40 horas semanais. Para os contratos, os que são feitos diretamente pela Secretaria compreendem 20 horas semanais, tanto para docentes quanto para auxiliares, e os contratos terceirizados, 40 horas semanais. Os vigias trabalham no regime 12x36 horas.

\begin{tabular}{|c|c|c|c|c|c|c|c|c|}
\hline Professor & $\begin{array}{l}\text { Idade } \\
\text { (anos) }\end{array}$ & Formação & $\begin{array}{l}\text { Tempo de } \\
\text { formado }\end{array}$ & Especialização & $\begin{array}{c}\text { Tempo } \\
\text { de } \\
\text { docência }\end{array}$ & $\begin{array}{c}\text { Docência } \\
\text { em área } \\
\text { rural }\end{array}$ & $\begin{array}{l}\text { Docência } \\
\text { na escola }\end{array}$ & Vinculo e regime \\
\hline Ana & 45 & $\begin{array}{l}\text { Serviço } \\
\text { Social e } \\
\text { Normal } \\
\text { superior }\end{array}$ & 16 anos & $\begin{array}{c}\text { Gestão } \\
\text { educacional }\end{array}$ & 18 anos & $\begin{array}{l}3 \text { anos e } \\
5 \text { meses }\end{array}$ & $\begin{array}{l}4 \text { meses } \\
\text { (saiu da } \\
\text { escola) }\end{array}$ & $\begin{array}{c}\text { Concurso público } \\
20 \text { horas } \\
\text { (40 h em outra } \\
\text { escola) }\end{array}$ \\
\hline Bia & 26 & Ensino médio & 7 anos & -- & 6 meses & 6 meses & 6 meses & $\begin{array}{c}\text { Concurso público } \\
20 \text { horas + dupla } \\
\text { regência }\end{array}$ \\
\hline Jacó & 46 & $\begin{array}{l}\text { Pedagogia e } \\
\text { Filosofia }\end{array}$ & 12 anos & & 12 anos & 12 anos & 8 meses & $\begin{array}{c}20 \text { horas + dupla } \\
\text { Regência }\end{array}$ \\
\hline Diva & 46 & Pró- formação & 14 anos & & 15 anos & 13 anos & 4 anos & $\begin{array}{c}\text { Contrato } \\
20 \text { horas + dupla } \\
\text { Regência } \\
\end{array}$ \\
\hline Edmar & 30 & Ensino médio & 11 anos & & 9 anos & 4 anos & 8 meses & $\begin{array}{c}\text { Concurso público } \\
20 \text { horas }+40 \text { horas }\end{array}$ \\
\hline Lucia & 58 & Ensino médio & 26 anos & & 24 anos & 2 anos & 2 anos & $\begin{array}{c}\text { Concurso público } \\
2^{\circ} \text { horas } \\
\end{array}$ \\
\hline Sônia & 47 & Ensino médio & 25 anos & & 25 anos & 4 anos & $\begin{array}{c}2,5 \text { anos } \\
\text { (saiu) }\end{array}$ & $\begin{array}{l}\text { Contrato } \\
20 \text { horas } \\
\end{array}$ \\
\hline Diretor & 59 & Magist. $1^{\mathrm{a}}$ a $4^{\mathrm{a}}$ & 6 anos & $\begin{array}{c}\text { Gestão } \\
\text { educacional } \\
\text { em conclusão }\end{array}$ & 23 anos & 23 anos & 4 anos & $\begin{array}{c}\text { Concurso público } \\
40 \text { horas }\end{array}$ \\
\hline
\end{tabular}

Quadro 4 - Descrição dos docentes e diretora da escola no ano 2008. 
Os contratos diretos têm duração de seis meses e podem ser renovados, mas geram grande expectativa, pois há sempre o risco de conclusão, principalmente quando há mudança na gestão pública. Os contratos terceirizados ficam sob responsabilidade de empresas ou cooperativas, mas também estão sujeitos a indicações de políticos e diretores de escolas. Essa dependência faz com que fiquem à mercê da gerência imediata, tendo também o dever de defender quem lhes deu o cargo, estimulando clima de competição, clientelismo e tráfico de influências.

"A confiança que ela depositou em mim, eu tenho que retribuir né" (Maria/merendeira).

"A SME te manda para o lugar, você vai porque se não for acaba o contrato. Lá tinha que carregar água para fazer merenda, para lavar [...] Agradeço a Deus por ter meu emprego, porque na minha idade é difícil contratar" (Roseli/auxiliar intermediário).

O ano de 2008 foi marcado por mudanças no quadro docente, em função da lotação de docentes efetivos, decorrentes do concurso público municipal realizado em 2006. As substituições foram realizadas no decorrer do primeiro semestre letivo, ocasionando diversas trocas de professores nas turmas.

No início do ano, a escola contava com uma professora concursada e três contratadas, todas com dobra de carga horária. Destas, uma perdeu o contrato, outra ficou na escola durante o primeiro semestre letivo e a terceira permaneceu no quadro docente, com uma carga horária de 20 horas semanais. Dos quatro professores concursados, três já possuíam outra cadeira no magistério, e um deles com uma carga horária de quarenta horas semanais, completando assim, o quadro docente mais que necessário para cobrir as oito turmas da escola. Este professor ministrava aulas nos três turnos. Conforme relato da diretora estas trocas ocasionaram significativos impactos no ano letivo, interferindo na proposta pedagógica estabelecida.

Para direção das escolas, foi estabelecido em 2006, pelo então Secretario Municipal de Educação, concurso público, específico para este fim. Antes de 2006, os diretores eram escolhidos pelo poder público, como cargo de confiança, muitos indicados por políticos ou mesmo como pagamento de promessas de campanha. No referido concurso, muitos diretores não foram aprovados, e perderam o cargo. A diretora, que já possuía cargo de gestor em outra unidade educacional rural, está na escola desde sua inauguração, por indicação política, mas participou do concurso para gestor e assegurou sua continuidade na direção da escola. Apesar do concurso, o cargo de diretor ainda é considerado pelos dirigentes governamentais e mesmo por muitos diretores, cargo de confiança, sendo deles exigido e cobrado "fidelidade" ao governo. 
Não parece haver diferença de tratamento, por parte da diretora da escola, em relação às categorias acima descritas. Cada funcionário possui seu horário de trabalho e dele é cobrado o cumprimento de suas funções, havendo flexibilidade. Não há extrema rigidez na cobrança de tarefas, horário e freqüência, com possibilidade de permutas, desde que se combine com os colegas uma substituição. Há exigência na execução da atividade, que "não deve de modo algum não acontecer por falta de funcionário, já que a escola tem um número até razoável para o seu tamanho" (diretora). O funcionário pode repor seu horário de trabalho em outro dia. Muitas vezes não há registro formal das faltas, mesmo quando não formalmente justificadas. Deve-se, entretanto, cumprir com o que foi estabelecido. Observaram-se algumas críticas a este procedimento, tanto no sentido de considerar que a diretora "dava confiança demais" (vigia), ou devia ser mais rígida em determinados momentos, quanto na direção oposta, valorizando certos procedimentos democráticos, em que se discutem as atividades e onde há liberdade, pois "cada um sabe seu lugar e função e é bom trabalhar num local onde não se fica cobrando o que você sabe que tem que fazer". (Roseli)

Observaram-se também descontentamentos entre os demais agentes em relação à postura autoritária de colegas, quando em exercício de funções de chefia, principalmente na ausência da diretora.

"Não vou me humilhar, nem deixar ninguém me humilhar (...) nem bem a diretora saiu e já tem gente querendo mandar" (Jane/agente operacional, referindo-se a uma professora).

"Aqui às vezes tem gente demais querendo mandar" (Ednelza/auxiliar matutino, referindo-se à agente operacional).

"Ela é como a gente, mas acha que pode mandar no nosso serviço" (Maria/merendeira, referindo-se à agente operacional).

Em relação ao local de moradia, um professor, dois auxiliares e a merendeira residem no bairro; os auxiliares, na Vila, e o professor, em uma comunidade localizada no lago. Para deslocar-se até a escola, este professor conta com condução própria, ou seja, um barco a motor (40HP). Os demais professores e técnicos moram em bairros distantes, utilizando o transporte escolar fornecido pela Secretaria de Educação para as escolas rurais. Um professor geralmente utiliza veículo próprio para ir até a escola.

Entre abril e setembro, houve uma professora na escola que também residia no bairro. Alegando questões de saúde, dificuldade de deslocamento e por haver vaga numa escola perto 
de sua casa, onde já leciona nos dois outros turnos (matutino e noturno), solicitou sua transferência.

Dos seis professores, dois são graduados, três estão fazendo a graduação em magistério de $1^{\mathrm{a}}$ a $4^{\mathrm{a}}$ série, e um professor cursou até o Ensino Médio. A diretora está concluindo especialização em Gestão Educacional. Dos auxiliares de serviços gerais, três possuem Ensino Médio completo e um o Ensino Fundamental. A merendeira está cursando a primeira etapa do Ensino Fundamental supletivo. O motorista possui ensino médio. E quanto aos vigias, um possui Ensino Fundamental incompleto e o outro está cursando o Ensino Médio, curso supletivo.

\begin{tabular}{|c|c|c|c|c|}
\hline Professor & Nível & Curso & Período & Estabelecimento \\
\hline Ana & Pós / Strictu & $\begin{array}{c}\text { Mestrado em } \\
\text { Educação }\end{array}$ & Seleção & Público \\
\hline Bia & Graduação & Pedagogia & $4^{\mathbf{o}}$ & Privado \\
\hline Diva & Graduação & Pedagogia & $6^{\mathbf{0}}$ & Privado \\
\hline Edmar & Graduação & Pedagogia & $8^{\mathbf{o}}$ & Privado \\
\hline Sônia & Graduação & Pedagogia & $8^{\mathbf{0}}$ & Público \\
\hline Diretora & Pós / Lato & $\begin{array}{c}\text { Gestão } \\
\text { educacional }\end{array}$ & Em conclusão & \\
\hline
\end{tabular}

Quadro 5 - Docentes em Aperfeiçoamento no ano 2008.

Há uma regularidade na vestimenta. Costumam usar calça jeans, com camisetas ou blusas leves, mais confortáveis para o trabalho em um clima quente e úmido. Embora o jeans não seja adequado a este ambiente, parece ter sido convencionado seu uso em função da praticidade e, de certo, da publicidade. Não há uniforme para os professores nem para os demais auxiliares, apenas para a merendeira.

O tempo de serviço varia de um a vinte e cinco anos. A diretora atua no magistério há vinte e três anos, e os professores entre dois e vinte e quatro anos. A maioria dos professores manifestou ter optado pela profissão, na certeza de ter feito a escolha certa, atribuindo-se certo dom ou vocação. Os demais agentes institucionais falaram da oportunidade de trabalho, principalmente com a expectativa de conquistar um emprego público (esta conquista pode se dar tanto pela via do concurso público como por indicação ou clientelismo político).

\section{Professora Ana}

Estabeleceu-se pouco contato com esta professora. Nas duas vezes em que ocorreu uma conversa e nos momentos em sala de aula, mostrou-se muito simpática, atenciosa e interessada em manifestar seus pontos de vista. 
Mora na Vila desde 1988, sendo membro de uma das famílias que primeiramente ali chegaram, e considerando-se, de certa forma, herdeira, ou pelo menos, descendente dos primeiros donos da terra. Mudou-se para o bairro logo após o casamento, mas mesmo antes de ali residir, frequentava esta comunidade desde criança, em períodos de festas e férias escolares, em visita aos parentes.

Medindo aproximadamente $1.65 \mathrm{~m}$, é branca, de pele castigada pelo sol, 45 anos, cabelos castanho-claros, cortados abaixo da orelha. Veste usualmente calça jeans, blusa de cor estampada, tecido fino. Usa óculos de grau elevado, e tem vários problemas de saúde, dentre eles, hipertensão, diabetes e cinco hérnias de disco, o que a faz ausentar-se para consultas e tratamentos médicos. Apesar disso, procura não faltar às aulas, sendo, segundo ela, mais frequente ao trabalho que outros professores.

Graduada em Serviço Social desde 1992, e em Normal Superior desde 2006, está concluindo curso de pós-graduação lato sensu em Gestão Educacional, e no ano 2007, participou de processo seletivo para um curso de mestrado em Educação, mas não foi qualificada, e isto a desestimulou bastante. Embora desanimada, está decidida a tentar novamente.

É professora da rede municipal há dezoito anos, inicialmente por contrato de prestação de serviços com a Secretaria Estadual de Educação, lecionando aulas de história, e posteriormente, com a Secretaria Municipal (SME). Desde então, foi indicada para ministrar aulas em uma escola próxima à sua casa, a escola da Vila, à época escola rural, e onde um irmão mais velho já lecionava. Em 2004 passou a integrar o corpo docente efetivo da SME, sendo lotada nesta escola, com carga horária de 40 horas semanais. Este fato foi significativo, garantindo-lhe status e segurança profissional, haja vista que outras professoras também residentes na comunidade não foram aprovadas no referido concurso nem em anteriores.

Apesar de presente no cotidiano dos professores rurais, a instabilidade profissional não assusta muito, pois os contratos também fazem parte de uma tradição, em que acordos políticoeleitoreiros exercem grande poder de influência, principalmente no que pode ser considerado "cargo de confiança", fazendo com que os funcionários procurem corresponder aos anseios de seus superiores e com que cada vez mais pessoas disputem vagas para cabos eleitorais de candidatos a cargos públicos. Isto acaba distribuindo cargos e funções para pessoas nem sempre qualificadas. Esta tradição tem diminuído, mas ainda existe.

A experiência da professora Ana, no ensino em área rural, restringe-se ao período em que a escola acima referida era considerada escola rural. Atualmente, é urbana. Isto lhe conferiu três anos de docência rural. Com aprovação no último concurso público municipal 
para o magistério do ensino fundamental, a professora foi lotada na escola objeto deste estudo, com a carga horária de 20 horas, a partir de abril/2008. Em função de desentendimentos com a direção da escola, de problemas de saúde que lhe dificultam o deslocamento, e tendo conseguido uma vaga na escola onde já lecionava pela manhã e à noite, solicitou transferência para a mesma em setembro.

Ana é altiva, severa, professora antiga, ancorada no que se pode considerar modelo tradicional de ensino, mas aberta a novas possibilidades. Extremamente falante, fala rápido e impõe seus pontos de vista, sendo considerada pelos pares e principalmente pela gestão da escola, como de difícil relacionamento. Considera-se prejudicada, pois costuma ser crítica e manifestar suas opiniões, o que nem sempre é bem visto por aqueles que "abaixam a cabeça para o poder". Considera-se ainda, apesar de não explicitamente, herdeira do poder local, disputando-o junto a membros de outras famílias também fundadoras da comunidade original.

Possui bom relacionamento com seus alunos, de quem cobra conhecimentos, cobrando, também, a dedicação dos pais. Trabalhou durante o período em que esteve na escola, com uma turma de $2^{a}$ série, no turno vespertino. Informou que procura manter diálogo com os pais, a fim de acompanharem juntos, o crescimento do aluno. Em relação ao método, não define um método de trabalho, mas usa um pouco de cada um que aprendeu. Valoriza a experiência ativa e a participação do aluno nas atividades em sala de aula e também fora da sala, quando possível.

A professora dedica parte de seu tempo registrando e pesquisando a história do bairro e de sua família, objetivando com seus relatos e registros fotográficos colaborar para estudos futuros sobre a origem da comunidade.

\section{Professora Bia}

Foi a última professora a chegar à escola (no mês de agosto), decorrente do concurso público, com carga horária de 20 horas semanais. Morena clara, alta, com 26 anos, mede aproximadamente $1,68 \mathrm{~m}$, cabelos compridos, castanho escuro, fios grossos, sempre presos em forma de rabo de cavalo, de fala baixa e suave. Usualmente veste calça jeans, uma blusa de meia-manga, em cores claras, geralmente branca, ou camiseta branca, sandália de salto alto do tipo anabela e tênis em algumas ocasiões.

Demonstrou ser calma e de fácil convívio, falava pouco, e muitas vezes, era convidada pelos colegas a chegar mais perto e participar das conversas do grupo, mantendo-se mais na posição de escuta do que expondo seus pontos de vista. Quando solicitada, procurava ser colaborativa, estando mais entrosada ao grupo e ao ambiente no fim do ano. Mantinha mais 
contato com o prof. Jacó, seja por seu jeito acolhedor e sua experiência como orientador educacional, mas também em função de trabalharem com séries/anos similares, fazendo conjuntamente o planejamento das aulas.

Reside em outra localidade, utilizando o transporte escolar para chegar ao trabalho e sair. Estava cursando o $4^{\circ}$ período de Pedagogia em faculdade particular e foi aprovada no último concurso público realizado pela prefeitura. Anteriormente, já havia trabalhado como professora do Ensino Fundamental na rede particular de ensino. Não possuía experiência no ensino rural, mas, em seu depoimento, disse não sentir muita diferença entre o que estava vivenciando e suas expectativas em relação à escola rural, acrescentando que os alunos possuem bastante dificuldade, e que o professor precisa se empenhar mais se quiser melhores resultados; que há correspondência por parte dos alunos, que são carinhosos e fáceis de lidar. Informou também que muitos alunos apresentam problemas, físicos, psicológicos e familiares, e isto é um fator que contribui para as dificuldades de aprendizagem. Em sua opinião alguns alunos necessitam apoio psicopedagógico.

A professora foi receptiva à presença da pesquisadora em sua sala de aula, mas manteve-se bastante reservada, e alguns momentos, insegura. Assumiu a turma de $2^{\circ}$ ano/ciclo (corresponde à $1^{\mathrm{a}}$ série), que era da profa. Sônia, no turno matutino, e a turma de $1^{\mathrm{o}}$ ano/ciclo, que já havia passado por três professores. Teve dificuldades para lidar com uma turma, mais agitada, e com o rótulo de "estar sentindo falta da professora anterior", frase que era expressa pela direção da escola, mesmo na frente dos alunos. Mostrava-se carinhosa para com os alunos, embora demonstrasse pouca habilidade para lidar com certas questões em sala de aula. Quanto à metodologia de ensino, foi possível observar que a professora tendo chegado à escola em agosto, não aderiu à proposta pedagógica desenvolvida pela diretora e pela professora anterior, apoiando-se em uma metodologia que pode ser considerada tradicional. $\mathrm{O}$ plano de trabalho era feito em conjunto com o professor Jacó, com a utilização de textos mimeografados, mas boa parte do trabalho dos alunos restringiu-se a cópias. Nos casos em que os alunos não conseguiam copiar do quadro, a professora escrevia em seus cadernos o nome completo do aluno, o alfabeto, listas de números, ou frases do tipo "eu amo Jesus", "você é meu amigo" para serem reproduzidos até o final da página. Outra atividade bastante desenvolvida era escrever de 1 a 100, a 200.

\section{Professor Jacó}

Simpático e falante, o professor é branco, aproximadamente 1,76m de altura, 45 anos. Usa óculos, fala alto, declarou gostar muito de cozinhar e comer. Sua vestimenta também 
comporta o jeans e alguma camisa pólo de cor escura, às vezes camiseta de malha ou outro tecido leve, e tênis. Costuma usar uma camiseta pólo azul clara com listras escuras. O professor transpira muito e está sempre com um lenço branco a enxugar o rosto. Gosta de conversar, geralmente sobre comida, mas também sobre outros assuntos, e de contar suas experiências como professor e como pedagogo. Mora em outra localidade e também utiliza o transporte escolar para deslocar-se até a escola.

É formado em Pedagogia, por uma Instituição Federal de Ensino Superior, há treze anos, e também em Filosofia, tendo doze anos de experiência docente no magistério de $1^{\mathrm{a}}$ a $4^{\mathrm{a}}$ série da rede pública de ensino, sempre no ensino rural, e assim o prefere, pois sente que o retorno é mais rápido. Participou do último concurso, adquirindo a segunda cadeira, ambas com vinte horas semanais, tendo chegado à escola em maio.

Pertenceu ao corpo técnico da Secretaria Municipal de Educação, na administração anterior, no período entre 2000 e 2004, participando como pedagogo da equipe de apoio às escolas rurais.

Experiente e conhecedor dos trâmites e funcionamentos da Secretaria de Educação, o professor fala com entusiasmo de projetos já desenvolvidos em outras escolas rurais onde trabalhou, e em escolas que acompanhou como pedagogo, mostrando as possibilidades de trabalho em uma área em que, apesar da dita falta de condições e evidente falta de apoio administrativo, é possível desenvolver trabalhos riquíssimos. Crítico a certos modelos e imposições, manifesta seus pontos de vista, procurando não falar abertamente sobre as políticas estabelecidas pelo poder vigente, e em determinados momentos, evitando posicionarse. O professor procura manter uma postura ética em relação ao trabalho e aos colegas, demonstrando interesse em partilhar experiências e auxiliar os colegas nas atividades pedagógicas, também evidenciando suas discordâncias com firmeza, mas com ponderação.

Em relação aos alunos, o professor assumiu a primeira série, no turno matutino e a Educação Infantil ( $2^{\circ}$ período) no turno vespertino. Tinha uma postura carinhosa com alunos da Educação Infantil, e a eles procurou dedicar-se, adquirindo com recursos próprios materiais para diversificar as atividades em sala de aula. Entretanto, com alunos repetentes da $1^{\mathrm{a}}$ série, o professor, em vários momentos mostrou-se irritado e irritável, utilizando linguagem agressiva e depreciativa. Sua fala alta e exasperada assustava os alunos, e pais chegaram a reclamar do modo como estava tratando os seus filhos, um deles alegando que um aluno não queria mais ir para a escola por medo do professor. O professor justificou que procurava estimular os alunos, que nunca utilizou de violência, queria "ver se despertava, mas foi mal 
compreendido". Observou que os alunos eram inquietos, desatentos, era preciso chamar atenção muitas vezes, não era possível dar aula.

"Como é que você vai ter autoridade se eles tão acostumados a dentro de casa os pais fazer tudo e na sala eles querem fazer tudo da mesma forma, e se você imprime uma autoridade, certo, e se for falar normal não atende, você fica sem fôlego!"

Sentiu-se bastante prejudicado em ministrar aulas no refeitório, espaço aberto e muito disperso, principalmente para uma turma que possuía diversos alunos com dificuldades de aprendizagem e outros problemas. Destacou haver, pelo menos, cinco alunos que necessitavam de acompanhamento especializado, e pelo que sabia, apenas um deles fazia tratamento médico.

Pelas observações realizadas, constatou-se que o professor desenvolvia seu trabalho adotando com a Educação Infantil uma metodologia de base construtivista, mas não fluiu nesta mesma proposta com os alunos da primeira série, onde as atividades restringiram-se a cópias e explicações ao quadro, e onde procurava disciplinar os alunos para permanecerem sentados e atentos. O professor chamava atenção de quem não estivesse prestando atenção. Conforme seu relato, gostou muito de trabalhar com a Educação Infantil, se surpreendeu com o desenvolvimento dos alunos. E com relação à primeira série, o professor citou a necessidade de construir com eles conceitos básicos desde higiene, disciplina, autoridade, mas isto permanece sendo um desafio. Mesmo não tendo expressado verbalmente, o professor demonstrou estar desafiado a investir nesse grupo de alunos.

\section{Professora Diva}

Esta professora reside no bairro, em uma comunidade ribeirinha no lago. Morena, cabocla, de cabelos pretos compridos e bem lisos, possui 1,60m, 46 anos. Costuma usar calças ou bermudas jeans, com blusas de alça em malha, algodão ou lycra, de cores lisas, ou um conjunto preto de colete e calça comprida, com alguma blusa leve por baixo. Está cursando o sexto período de graduação em pedagogia em uma faculdade particular.

Conforme relatou, estudou até o terceiro ano do ensino médio, à época segundo grau profissionalizante em Administração, mas não concluiu, por ter se casado e mudado definitivamente para área ribeirinha. Por necessidade de professores para trabalhar na localidade onde morava, candidatou-se como professora leiga, obtendo posteriormente a titulação, através de um curso denominado Pró-formação. 
Possui 15 anos de docência, e treze anos como professora contratada pela Secretaria Municipal de Educação para atuar na área rural. Participou de concursos públicos, mas não foi aprovada, permanecendo no regime de renovação de contrato por tempo indeterminado. Está nesta escola desde 2005, e antes trabalhou em duas outras escolas rurais dentro do lago. É a única professora que está na escola desde sua fundação.

Em função da chegada dos professores efetivos, a professora perdeu uma carga horária, e a regência de turma, ficando na escola apenas no horário vespertino, como professora de apoio. Como houve vacância na escola da Vila, e por ser uma pessoa conhecida e influente na comunidade, conseguiu a dobra de carga nesta escola, pelo horário matutino. No segundo semestre, com a chegada de mais um professor efetivo, foi dispensada, mas por pertencer à diretoria executiva do Conselho Escolar, e por lobby da diretora, foi mantida na escola como professora de apoio. Retornou à sala de aula somente em outubro, com a saída da professora Ana.

Diferente dos demais agentes, utiliza o barco para sua locomoção. Em seu percurso diário, são quinze ou vinte minutos de barco até chegar à Vila, onde leciona no horário matutino, depois uma caminhada a pé até a escola objeto deste estudo. Ao fim da tarde, sobra pouco tempo para ir a casa, vestir-se e retornar de barco até a Vila, onde pega o ônibus para ir à faculdade, e retornar no mesmo percurso ônibus/barco. A professora comentou sobre as dificuldades de morar no lago.

"Todo dia essa rotina, de três pilar, aqui, lá e lá. É um pouco sacrificoso. Olha, é pra gente ter muita força de vontade. Quando é só chegar na Vila e ta em casa tudo bem, mas pega barco, 15 minutos de motor, alta hora da noite, tudo escuro, vem de ônibus, né. Sai da faculdade, no dia cedo trabalha, se perder o ônibus de dez pras dez, mana, só dez e trinta. Às vezes não tinha ônibus, aí..."

E também da disponibilidade "a gente tem força de vontade, a gente vai que consegue, nada é cansaço”.

A professora demonstra orgulho e segurança no desempenho de seu trabalho, com uma postura-mistura tradicional/inovador, em que o professor ensina os conteúdos e os alunos devem prestar bastante atenção para poder aprender. Compreende que o ensino envolve a participação dos alunos nas atividades, mas que devem obedecer e o silêncio e controle da disciplina são importantes em uma sala de aula. Deve haver também momentos de descontração e de participação dos alunos, onde "é inevitável falações e circulação pela sala de aula”. Mas isto também contribui para o desenvolvimento do aluno. 
Em relação à metodologia de ensino, diz que na escola rural trabalha-se com o que tem, pois a infraestrutura é precária, não se pode contar com os pais, a grande maioria é analfabeta e sem recursos. Há que se considerar também que a criança vai para lavoura acompanhando os pais, que muitas vezes não tem com quem deixar o filho, além de necessitar desta mão de obra, pois o período de colheita é curto, e quanto mais gente melhor. Também em função do trabalho esporádico e ausência de vínculo empregatício, os pais costumam migrar muito, saindo de um sítio para outro, de uma localidade para outra, às vezes mais distante, o que faz com que os alunos cheguem e saiam durante todo o ano. "Isso dificulta um acompanhamento efetivo do aluno e não há metodologia que dê jeito”. Defende a proposta metodológica proposta pela diretora, a Pedagogia de Projetos, pois trabalha em cima das necessidades do aluno, do contato com a comunidade, e onde professores e alunos devem pesquisar. "Um projeto onde se vê que tem bom resultado, e positivo".

Demonstrou interesse em participar da pesquisa, e receptividade à presença da pesquisadora, colocando também sua turma à disposição, caso a pesquisadora quisesse desenvolver atividades junto aos alunos.

\section{Professor Edmar}

Alto, aproximadamente $1,85 \mathrm{~m}$ de altura, moreno claro, cabelos curtos suavemente encaracolados, 30 anos, estrutura física forte. Edmar tem boa potência de voz, não costuma falar alto, apenas quando chama atenção dos alunos usa seu recurso vocal.

Também veste jeans, e camiseta branca com propaganda de algum evento, seja congresso, semanas ou projetos em que participou, como Semana do Meio Ambiente, Semana Nacional de Ciência e Tecnologia, Encontro de Ribeirinhos. Está sempre de tênis.

O professor reside em outra localidade e costuma ir de condução própria para a escola. Raramente faz uso do transporte escolar.

Está cursando o último ano de Pedagogia em uma faculdade particular e manifestou interesse em dar continuidade à formação, com estudos pós-graduados. Comentou sobre um projeto que desenvolvia na escola onde anteriormente lecionava, e que pretendia apresentá-lo para seleção de mestrado, mas em função do concurso para professor, teve que adiar a pósgraduação, pois está em período probatório e não poderá ser liberado para estudos no presente momento. Não pode também arcar com a manutenção de família e estudos sem a dupla jornada de trabalho. Comentou que no momento está reticente, pois pensa em como irá conciliar trabalho e estudo, mas tem sido bastante estimulado por colegas a não desistir, pois 
seu projeto foi bastante elogiado, chegando a ser selecionado para representar a secretaria em uma mostra de estudos e pesquisas sobre a Amazônia.

Possuía uma cadeira na Secretaria Municipal de Educação com carga horária de 40 horas semanais, desde 1999, e seis anos de docência rural. Foi novamente aprovado no último concurso, este com 20 horas. Por isso, ministrava aulas nos três turnos e a vinda para esta escola lhe foi conveniente, haja vista poder trabalhar em um único local, no período entre 7:30 e 16:30. Na escola rural onde lecionava não havia três turnos, e em função da distância, ficaria difícil continuar lá e trabalhar em outro local. O professor lamentou a saída da escola no momento em que desenvolvia um projeto que considerava importante, tanto para a escola e a comunidade, como para si mesmo. Antes de atuar como professor, possuía uma locadora e lan house, manifestando bastante interesse em atuar mais como professor de apoio, junto a projetos e laboratórios de informática, do que como professor regular.

Ministrava aulas para as séries mais adiantas e alunos mais velhos, com duas turmas de terceira série e uma de segunda.

O professor teve embates com a direção da escola, entendendo que a metodologia de trabalho não deveria ser imposta pela direção e sim uma opção pessoal de cada professor. Marcava suas opiniões e pontos de vista, geralmente perguntando a opinião do colega a respeito de alguma situação e depois se posicionando, expressando o que pensa. Após embate com a diretora em função de divergências metodológicas, permaneceu um tempo restrito a seu trabalho em sala de aula, pouco se relacionando com os demais colegas. Mas, por iniciativa da diretora e dos professores, que lhe fizeram uma pequena homenagem após o nascimento de sua filha, foi lentamente se aproximando do grupo. Suas falas em geral versavam sobre que dia sai o pagamento, possibilidades de aumento, sobre as questões políticas da cidade, e do desenvolvimento e peripécias de sua filha.

Demonstrou bastante interesse em falar de projetos que já desenvolveu na escola em que trabalhara anteriormente. Um deles em especial, que trata sobre a exploração do trabalho infantil na produção de carvão, intitulado "meninos carvoeiros", em que procurou analisar e denunciar as precárias condições de vida e de trabalho de crianças e adolescentes, nos arredores da cidade, projeto que pretende continuar desenvolvendo um dia.

Pouco solícito ao trabalho coletivo, pelo menos nesta escola, cumpria o estritamente necessário, demonstrando alguma insatisfação com as condições de trabalho.

Tinha uma postura autoritária diante dos alunos, procurando manter o controle da disciplina que, segundo o mesmo, é um aspecto necessário para a aprendizagem, pois o que atrapalha alguns alunos é a dispersão. Apesar de seu jeito severo, possuía bom relacionamento 
com os alunos, que em relatos informais disseram gostar do professor e lhe consideravam um bom professor, por "passar muito trabalho, ser exigente e duro".

O professor também estimulava a produção escrita de seus alunos, sempre apresentando nos eventos promovidos pela escola peças, pequenos textos e poesias, segundo ele, escritos pelos próprios alunos. Comentou parecer que os alunos não tinham disciplina suficiente ou não estavam acostumados a estudar. Partindo de uma perspectiva metodológica que podemos considerar tradicional, o professor procurava enfatizar a aprendizagem dos conteúdos. Em seu relato, falou dos alunos repetentes, de grande dificuldade que apresentavam, e que o modelo que eles tinham era esse de copiar, e cobrar que façam a atividade. Informou que adotou então, como método de trabalho, a seguinte estratégia: procurava explicar primeiro a atividade, demonstrar como se faz, passo a passo, fazer um exercício junto com os alunos, e somente depois passar os exercícios. Explicou que assim, pode ver os que estão acompanhando e os que não conseguem. Falou da dificuldade dos alunos também em função da falta de acompanhamento em casa, pois muitas vezes eles são os que estão mais adiantados em termos de escolarização, e também da infrequência. Há alunos que estão reprovados por falta.

\section{Professora Lúcia}

É a única professora da escola que possui apenas o Ensino Médio. Disse que começou a cursar a faculdade por duas vezes, mas interrompeu em função de problemas de saúde na família, e depois sente que não tem mais condições nem paciência para retornar ao banco de escola e fazer faculdade, embora desejasse aposentar-se com o título de formação superior, como várias colegas de sua idade.

Senhora de 56 anos, branca, estrutura física franzina, aproximadamente 1,67m, cabelos castanho-claros, curtos e pintados, usa óculos para corrigir miopia. Usualmente está de jeans, e blusas de linha ou outro tecido leve, geralmente de alça. Simpática e atenciosa, de bom relacionamento com os demais colegas, procurou ser a ponte entre direção e professores em determinados momentos, provavelmente por estar na condição de professor de apoio, tendo sido também bastante atenciosa com a pesquisadora.

Formada há 25 anos, possui o adicional em Matemática, que lhe permitia trabalhar também com aulas de Matemática para $5^{\mathrm{a}}$ e $6^{\mathrm{a}}$ séries. Possui 25 anos de experiência no magistério, como professora efetiva do quadro da Secretaria de Educação, e apenas dois anos em área rural, nesta escola. Participou do último concurso público, mas não foi aprovada. Tinha carga horária dobrada, ministrando aulas nos turnos matutino e intermediário. Em 
função da chegada dos professores efetivos, perdeu a dobra de carga, e passou a ocupar a função de professor de apoio no turno matutino. Com a possibilidade de cumprir sua carga horária até as $10 \mathrm{~h} 30 \mathrm{~min}$, foi possível conseguir uma vaga em outra escola. Para conseguir chegar a tempo ao outro local de trabalho, precisava sair da escola impreterivelmente às 10h30min. Reside em outra localidade, e utiliza o transporte escolar para deslocar-se até a escola.

Em observações realizadas nos momentos em que a professora substituiu colegas em sala de aula e em sua entrevista, constatou-se que a mesma tem uma postura tradicional, e um jeito severo de lidar com os alunos. Tendo bom domínio de sala de aula, não acredita nos métodos atuais, embora manifeste certa disponibilidade para aprender, e tentar corresponder ao que a diretora pede e sugere. Entende que a responsabilidade pela escola é da diretora e que, como subordinada, deve procurar atender. $\mathrm{O}$ que a instiga é saber se é responsabilidade do professor o fato de os alunos apresentarem dificuldade em aprender. Descreveu a situação de um grupo de alunos, que passou por quatro professores, segundo ela, quatro metodologias diferentes, e não obtiveram resultado satisfatório. Questiona: "se vários professores já tentaram e não houve êxito, então será que o problema está nos métodos?".

Também concorda com os outros professores que os alunos apresentam muita dificuldade, atribuindo aos pais certa responsabilidade, pela falta de apoio e de escolaridade. Comentou que tendo trabalhado durante toda sua vida em escolas periféricas, não percebeu muita diferença entre escola urbana/periférica e escola rural, onde "o índice de evasão, de reprovação, de desinteresse, tudo é o mesmo, só o tamanho da escola é que muda". Entretanto, observa que a participação dos pais na escola rural é maior, mesmo tendo mais dificuldades.

Gosta de conversar, mas mantém suas opiniões e pontos de vista com reserva, não entrando em confronto direto para estabelecer suas opiniões.

\section{Professora Sônia}

No ano de 2008, esta professora esteve na escola apenas durante o primeiro semestre letivo. Senhora, 47 anos, morena, cabelos curtos, pintados em castanho claro, de média estatura, séria, e nas conversas informais em que a pesquisadora esteve presente, costumava tratar dos assuntos da escola.

Diferencia mais suas vestes, usando conjuntos de calça comprida e coletes em cores escuras, sempre combinando, com blusas de linha ou outro tecido leve. 
É uma professora tradicional, há 25 anos, com experiência basicamente no ensino particular, e com Educação Infantil. Na rede pública, possui contrato com a Secretaria de Educação desde 2006, tendo três anos de experiência em ensino rural, e nesta escola. Concluiu o magistério e o adicional em 1983, e atualmente cursa o sexto período do curso de graduação em Pedagogia, em uma faculdade particular.

Séria, procurava desenvolver seu trabalho com competência, mantendo os alunos sempre em atividade, diversificando os trabalhos em sala de aula, corrigindo todos os trabalhos, passando atividades para casa. Tinha bom relacionamento com os alunos, procurando mantê-los sempre em silêncio e em atividade. Em sua substituição, alguns alunos sentiram muita falta.

Manifestou ter dificuldades em expressar suas idéias por escrito, procurando apoio na direção ou com os colegas, com sugestões para redigir seu plano de trabalho. Procurava com zelo dar conta de suas atividades, principalmente das idéias da diretora, com quem desenvolveu os projetos "vila do ABC", "o sonho da vovó Margarida”, o Projeto Temático da escola, dentre outros, relacionados à Educação Infantil.

Relatou que possuía muita dificuldade para lidar com esta realidade, tanto no que diz respeito aos alunos quanto ao método, instrumentos e falta de material. Teve dificuldades em dialogar com a metodologia proposta pela diretora, mas sente que depois de compreendida traz resultados favoráveis. Assim, em seu trabalho, procurou desenvolver atividades voltadas para a construção do conhecimento, sempre avaliando para saber se está alcançando os objetivos.

$\mathrm{Na}$ entrevista, a professora mostrou-se aparentemente receptiva, mas vestiu-se inicialmente de uma máscara supostamente acadêmica, procurando falar do muito que aprendeu e tem aprendido com os professores em suas aulas na graduação. Depois, mais relaxada, falou das dificuldades de lidar com a situação de contrato. Participou do último concurso público e não foi aprovada. Foi colocada na lista de contratos suspensos e somente conseguiu permanecer na escola por influência da diretora, que, por considerá-la o braço direito na implantação dos projetos junto à Educação Infantil, fez o que pode para segurar seu contrato na escola e articular outra vaga, a fim de que a professora não tivesse rua renda diminuída. Em fins de maio, conseguiu vaga em uma creche em outro bairro, localizado na zona norte da cidade. Isto ocasionou uma dificuldade, pois necessitava sair às pressas da escola para poder chegar a tempo na creche. Assim, no segundo semestre, houve a possibilidade de dobrar a carga horária na creche e a professora saiu da escola. 


\section{Diretora}

Simpática, sorridente e disponível, foi bastante receptiva à realização da pesquisa. Morena, magra, 59 anos, 1,59m, cabelos curtos, usualmente veste calça jeans, blusas de cor lisa, e um colete preto por cima. Considera-se uma pessoa bastante ativa e motivada pelo trabalho, que procura desempenhar com dedicação.

Graduou-se em Pedagogia, através do Programa Especial de Formação Docente, programa desenvolvido com recursos do Fundo Nacional de Desenvolvimento do Ensino Fundamental (FUNDEF), numa parceria entre a Secretaria Municipal de Educação (SME) e uma Instituição Federal de Ensino Superior, que capacitou grande parte dos professores da rede pública municipal de Ensino Fundamental.

Possui vinte e três anos de trabalho em educação rural, e está nesta escola desde sua inauguração. Iniciou a carreira docente como agente de educação rural, sendo posteriormente lotada como professora. Comentou sobre as dificuldades neste processo, pois os agentes pensavam que seriam como assessores, ou um grupo de apoio, mas não professores. Explicando sobre o processo que culminou na reclassificação dos agentes de educação rural para professores, comparou com os agentes de saúde, que não se tornam enfermeiros ou médicos, e disse que foi uma surpresa quando foram lotados em salas de aula. Muitos se assustaram, alguns desistiram e talvez por isso os que resistiram ficaram tão unidos, pois um ajudava o outro. Relatou com satisfação que traz, em sua experiência, a implantação de serviços e projetos ambientais que até hoje estão em funcionamento.

Sempre trabalhou em escolas rurais unidocentes, nas quais o professor é o único agente e, portanto, professor, diretor, secretário, merendeiro, servente, enfermeiro, orientador, "é um pouco de tudo ao mesmo tempo". Esta experiência lhe possibilitou conhecer a vida das comunidades ribeirinhas, e gostar do que faz. Possibilitou também conhecer os trâmites burocráticos e aprender como se movimentar nos setores da Secretaria Municipal de Educação para ser atendida em suas reivindicações, objetivando melhorias para a escola. Assim, conseguiu e mantém o transporte escolar, a manutenção do poço artesiano, a renovação do contrato de alguns professores, um quadro de funcionários suficiente para não sobrecarregar nenhum colega, a regularização da unidade educacional em junho de 2008, que funcionava desde 2005 sem "ato de criação". Sua última meta está sendo lutar pela ampliação do espaço físico. Enfatizou que aprendeu a documentar tudo o que faz.

Logo nos primeiros contatos com a pesquisadora, esclareceu que o sóciointeracionismo era a perspectiva teórica adotada pela escola, e que trabalhavam com a pedagogia de projetos. Em sua opinião, o trabalho da escola deve pautar-se no atendimento às 
necessidades do aluno e na formação de um cidadão pleno, consciente e ativo. Por isso, entende que é necessário partir de sua realidade e promover a participação da vida em comunidade. Em sua experiência, observou que esta metodologia favorece a construção de uma escola inserida na realidade da comunidade.

Informou que, como diretora, sente-se responsável pelo gerenciamento da escola, e também pelo acompanhamento das atividades pedagógicas, pois não dispunha de profissionais para este atendimento. Que a SME dispõe de uma equipe de apoio pedagógico, que visita as escolas quando solicitada, mas é uma agenda insuficiente para desenvolver um trabalho mais consistente, pois são muitas escolas e poucos profissionais. Além disso, na visita que esta equipe fez à escola em 2008, questionaram o uso da metodologia, dizendo que os professores não são obrigados a utilizá-la, e se o trabalho não surte os efeitos esperados, deviam mudar o método, mas não propuseram nenhuma solução ou alternativa ao tradicional "problema de aprendizagem".

Quanto ao ambiente de trabalho, disse que gosta do trabalho em equipe, procurando desenvolver uma gestão participativa. Considera que há responsabilidades que são da competência do diretor, pois é este que responde oficialmente pela escola, mas procura ouvir a opinião dos colegas. O plano de ação da escola é feito em conjunto com o grupo de professores, dividindo tarefas e responsabilidades. Entende que cada um sabe sua função, e que sua atribuição não é vigiar ou fiscalizar, mas cobra a execução do que foi planejado, quando necessário, pois está à disposição para ajudar e sempre que possível, procura atender às demandas dos funcionários. Esta disposição envolve desde ouvir as demandas (pessoais ou profissionais) e buscar soluções conjuntas, até a realização de pesquisas na internet, apoio na elaboração dos projetos e material pedagógico ou mesmo ir para a máquina de costura preparar a vestimenta do coral. Acredita que conversando se pode chegar a acordos, tudo é possível, mas o principal são os alunos. Por isso gosta de ser informada quando há algum problema, principalmente quando alguém precisa se ausentar, a fim de que possam organizarse a tempo, pois uma atividade planejada seja um evento, reunião, merenda ou manutenção, "não deve de modo algum não acontecer por falta de funcionário, já que a escola tem um número até razoável para o seu tamanho". Para ela, o diálogo é o instrumento mais adequado para o bom andamento do trabalho, e deve ser praticado cotidianamente. Procura ouvir com atenção, e gosta de ser ouvida. Nas reuniões com a comunidade, sempre abre espaço para que os pais questionem, se manifestem, avaliem o trabalho realizado pela escola. Tem facilidade em conduzir as questões de modo a fazer prevalecer suas idéias, e bons argumentos quando algum questionamento vai contra seus pontos de vista, mas acata decisões que foram tomadas 
no coletivo. Para motivar a equipe, ou mandar algum recado, traz sempre alguma mensagem (pensamentos, poesias) a ser lida nas reuniões ou afixada em cartazes.

Sente-se realizada profissionalmente, ou melhor, em realização, pois ainda há muito por fazer, e mesmo por imaginar. Fez questão de mencionar que não recebia gratificação pela função de diretora, mas isso não mudava em nada seu compromisso profissional. Ao contrário, talvez até lhe dê mais garra para continuar. Já teve oportunidade de voltar para outras escolas, ou sair e assumir outras funções, mas não quis. Comentou que os pais da escola em que trabalhou anteriormente até fizeram um abaixo-assinado para ela voltar. Acha que ainda precisa realizar algumas coisas nesta escola, como por exemplo, sua ampliação.

Em relação ao projeto pedagógico, informou que não tendo ato de criação, a escola não poderia ter projeto pedagógico, pois oficialmente não existe, mas todas as atividades eram planejadas tomando como base o Projeto Temático da escola, que era elaborado conjuntamente com os professores, no início do ano letivo ou fim do ano anterior, analisando a temática em função das necessidades dos alunos e da comunidade. Justificou não ter tido tempo para a construção do projeto pedagógico no segundo semestre de 2008, após a regularização da escola, pois esteve bastante envolvida neste processo, e posteriormente com a criação do conselho escolar. Além disso, as constantes mudanças de professores inviabilizaram a solidificação do grupo. Houve problemas com dois professores recémcontratados, principalmente no que dizia respeito à metodologia. Estes defendiam que o trabalho em sala de aula é de responsabilidade do professor, que tem o direito de escolher o método com o qual irá trabalhar. Ambos saíram da escola, um no segundo semestre e o outro no fim do ano.

Quanto aos avanços, colocou que o trabalho realizado com as famílias tem lentamente surtido efeitos. No início as relações foram tensas, a comunidade era mais resistente. Mas investiram na aproximação, procurando deixar claro que há objetivos comuns, ou seja, todos almejavam a educação dos filhos/alunos, e que somente juntos conseguiriam procurar alcançar seus objetivos, ou ter bons resultados. Observou que a comunidade possui carências, os pais têm muitas dificuldades tanto financeiras como pessoais e de relacionamento. Há mães muito jovens e inexperientes, que precisam de apoio na educação dos filhos. Há vários casos de violência e desagregação familiar, e estas situações interferem diretamente na aprendizagem dos alunos. Então, optou por desenvolver um trabalho direcionado para a relação escola-comunidade, objetivando envolver mais as famílias, e poder falar sobre a não violência, o cuidado e a amorosidade. Disse que está sempre batendo na mesma tecla, ou seja, os pais precisam dedicar um tempo a seus filhos, devem acompanhar seu desenvolvimento e 
não devem ser violentos. Procura também alertar os professores para o cuidado com as palavras, com o modo como vão dizer certas coisas para os alunos e para os pais, para evitar que estes, não compreendendo a mensagem, acabem tirando o filho da escola. Comentou que há falta de compromisso por parte de alguns pais, mas não pode deixar de considerar que muitos pais passam por sérias dificuldades. Percebe que a maioria valoriza o trabalho desenvolvido pela escola.

No relacionamento com os alunos, era bastante carinhosa e atenciosa, sempre recebendo abraços e desenhos. Conforme depoimento de um funcionário, "quando ameaçam mandar os alunos para a diretoria eles vão rindo, devido essa boa convivência" (Sr. João).

Disse que dificuldades existem para serem superadas, mas considera que teve muitos problemas em 2008, considerando-o um ano problemático. Por exemplo, as várias substituições de professores durante o período letivo, dentre outros acontecimentos, desestruturaram um trabalho que vinha desenvolvendo há três anos. Também o fato de ser ano eleitoral produz um ambiente instável, e em função de seus posicionamentos políticos e por não aceitar as indicações eleitorais vindas da SME, sentia estar sendo boicotada, mas mantinha suas decisões e opções, arcando com as conseqüências disto e articulando-se para assegurar suas conquistas.

\section{$\underline{\text { Jane - Agente operacional }}$}

Morena, de estatura baixa e robusta, aproximadamente 1,55m, 47 anos, cabelos pretos lisos, à altura dos ombros, sempre presos à cabeça, fisionomia cabocla. Costumava usar jeans e blusas de alça de cores escuras. Possui o Ensino Médio completo e conhecimentos em informática.

Tem interesse em continuar os estudos, e cursar graduação em Serviço Social, mas considera que precisa de grande investimento para prestar o vestibular e que no momento não dispõe de tempo nem recursos.

Conforme relatou, foi inicialmente contratada para trabalhar junto à Secretaria de Saúde, e solicitou transferência para a Secretaria de Educação. Trabalha na escola desde 2006, onde começou como auxiliar de serviços gerais, e também no apoio à merenda. Por sua experiência em setores administrativos e conhecimentos em informática, foi desviada de função pela diretora para apoio operacional, haja vista que a escola não tem secretaria, muito menos secretária. A carga horária dos contratos é de seis horas. Em acordo com a diretora da escola, para não deixar a secretaria descoberta, trabalhava segunda a quinta-feira, das sete e trinta às dezesseis e trinta horas. Entretanto, no segundo semestre letivo, em função da 
quantidade de serviços, acabou trabalhando muitas sextas-feiras. Não tinha a gratificação de função até o ano 2008, conseguindo-a em 2009, pela influência da diretora junto ao grupo político que assumiu a prefeitura neste ano, reconhecendo seu desempenho e dedicação.

De feições sisudas, com um ar desconfiado, era considerada pelo grupo como carrancuda, mal humorada e de difícil relacionamento. Conforme relatos informais, sentia-se com o dever e o poder de fiscalizar o funcionamento da escola e ditar o modo certo de fazer o serviço. Observaram-se suas reclamações com relação ao trabalho de determinados colegas e, em alguns momentos, seu descontentamento com o próprio local de trabalho. Mas, por outro lado, procurava se fazer útil, seja na organização da secretaria ou no apoio às atividades desenvolvidas na escola, sendo um braço de apoio à diretora.

Ao primeiro contato, não fala muito, apenas observa e se mantém com ar fechado e distante. Em relação à pesquisadora, disse que no início não gostava de sua presença questionando o porquê de estar na escola. ("Lá vem ela de novo! O que será que tanto vem fazer aqui?"). Com o convívio, demonstrou receptividade à pesquisadora, apesar de sempre atenta ao que pudesse acontecer. Demonstrou também uma sensibilidade enclausurada, e embrutecida pelo sofrimento.

Comentou sobre a insegurança dos contratos, por serem renovados a cada seis meses, mas demonstrava estar tranquila, como se tivesse garantia da renovação de seus contratos. Comentou do seu descontentamento, principalmente com uma professora que substitui a diretora, e com quem teve desentendimentos. Disse que se a diretora não permanecer na escola, ela pede sua transferência para outra Secretaria.

\section{$\underline{\text { Ednelza - Auxiliar matutino }}$}

Jovem, a mais jovem do grupo, aparentando ser mais velha do que seus 25 anos. Morena, de estatura média, em torno de 1,60m, cabelos pretos e lisos, um pouco abaixo dos ombros, mantidos presos para facilitar no trabalho. Usualmente veste bermuda, blusas de alça ou camisetas, e chinelos de dedo, roupas que facilitem seu trabalho. Costuma vestir-se assim no dia a dia, demonstrando ser uma pessoa simples, e muito reservada.

Nasceu na Vila, neta de uma das famílias que primeiro chegou naquela localidade. Concluiu o Ensino Médio, e com ele, os anos escolares e de juventude. Engravidou aos dezessete anos, e uniu-se ao pai de seu filho, tendo logo em seguida outro filho, iniciando uma trajetória que ela descreveu como de dificuldades financeiras, desentendimentos conjugais, separação e busca de trabalho para o sustento de seus filhos. Sabendo que a Secretaria de Educação estava contratando pessoal de apoio para trabalhar nas escolas ribeirinhas, 
encaminhou seu currículo e foi contratada, em meados de 2005, para trabalhar em uma escola localizada no lago, lá permanecendo por dois anos. No início de 2008 conseguiu renovação do contrato para trabalhar na escola objeto desta pesquisa, como auxiliar de serviços gerais, no turno matutino, entre sete e treze horas.

Alegando os problemas familiares, e a saúde de seus filhos, costuma faltar ao trabalho, o que é visto pelos colegas como um problema, pois deixa o serviço descoberto. Não gosta de falar, procura desempenhar seu trabalho, dentro do mínimo necessário para permanecer no emprego. Após desentendimentos com o companheiro e seus parentes, retornou à casa de seus pais, onde mora atualmente.

Acha bom o trabalho, por ser perto de casa, não ser tão cansativo, pois a escola é pequena e fácil de fazer a manutenção, além de poder contar com outros colegas para realização de serviços mais pesados e para permutas, quando precisa faltar. Além disso, trabalha só pela manhã, sobrando bastante tempo para cuidar dos filhos.

Considera que deve fazer seu trabalho e procura não se envolver com as demais situações escolares ou da comunidade. Também comentou que precisa se dedicar mais, e que pretende matricular os filhos na escola no próximo ano, pois tendo os filhos por perto, acha que faltará menos. Informou ainda que não tem muito contato com a comunidade, só vai lá trabalhar e volta para casa, não costuma sair de dentro da escola, não sabe como é a comunidade.

Acha que a diretora é muito rígida, mas também compreensiva, e que a comunidade gosta muito dela. Seu relacionamento com os alunos restringe-se a ajudar a distribuir a merenda, de vez em quando.

\section{Roseli - Auxiliar Intermediário}

Senhora de meia idade, 52 anos, aproximadamente 1,60m, feições caboclas, cabelos pretos, lisos, à altura da nuca, presos quando está em serviço. Adotou como seu uniforme o uso de uma camiseta branca e uma calça comprida de cor azul escuro, que veste quando chega à escola. Segundo informou, isto economiza roupa, pois como não mora na comunidade, precisa estar limpa e arrumada para o deslocamento entre sua casa e o trabalho.

Possui o Ensino Fundamental completo, e contrato de trabalho para o turno intermediário, entre dez e dezesseis horas, portanto, não utiliza o transporte escolar, necessitando tomar duas conduções para chegar ao local de trabalho.

Foi contratada pela Secretaria Municipal de Educação há três anos, para trabalhar em escolas rurais ribeirinhas, iniciando em uma comunidade distante. Nestes casos, os 
profissionais permanecem na comunidade durante a semana, retornando para casa às sextasfeiras, ou melhor, optam por retornar apenas uma ou duas vezes ao mês, pois o vale-transporte não cobre custo de deslocamento. Conforme relatou, o salário não cobre as despesas. No início do ano 2008, veio transferida para esta escola. Antes deste contrato, trabalhou como agente de saúde em comunidades ribeirinhas, mas por motivos de doença na família - o marido fez um acidente vascular cerebral ${ }^{16}$, precisou sair do trabalho para cuidar dele.

A auxiliar também relatou as grandes dificuldades nas comunidades ribeirinhas mais isoladas. O trabalho envolve limpeza e alimentação, incluindo carregar água para fazer a merenda, para limpar a escola, e improvisar, pois falta muito material. Também comentou sobre a insegurança de se trabalhar com um contrato renovável a cada seis meses, acrescentando que "se te mandam para um lugar, você vai porque se não for acaba o contrato".

Inicialmente reservada, foi se entrosando e galgando espaços, estando mais integrada e tranquila ao fim do ano, principalmente após assegurar-se de que seu contrato, como os demais, seria mantido até o ano seguinte.

Em função de problemas pessoais e de saúde, necessitou ausentar-se várias vezes. Isso gerou um clima de insatisfação no grupo, e alguns desentendimentos com a agente operacional, com quem também tinha outras divergências. Com isso, e de estado emocional tenso por causa de uma cirurgia, passou um tempo desconfiada, espinhosa e resistente a críticas, dizendo estar ali para cumprir estritamente seu horário e funções. Tinha mais proximidade com Ednelza, de quem se afeiçoou e com quem conversava mais abertamente e desabafava. Licenciou-se em agosto, para o procedimento cirúrgico, retornando em meados de setembro. Com o tempo foi se localizando melhor no grupo, procurando ser atenciosa e corresponder ao trabalho, pois, tendo faltado muito em função do tratamento médico e de problemas pessoais, temia não permanecer na equipe, ser transferida para local mais distante/de difícil acesso, ou ainda não ter seu contrato renovado.

Em relação à pesquisadora, foi sempre atenciosa e solícita, querendo conversar, contar um pouco de sua história, falar de seus problemas e de suas experiências, emitir opiniões sobre os assuntos conversados, sentindo-se bastante à vontade. Em seu relato procurou deixar claro, este era o modo como pensava ou fazia, mas que outros podiam fazer de forma diferente, não quer dizer que ela estava certa. A partir de sua experiência, tinha críticas ao

\footnotetext{
16 AVC - Acidente Vascular Cerebral, popularmente denominado derrame.
} 
trabalho de colegas, mas tinha o cuidado de falar no momento que considerava mais apropriado, ou então deixar pra lá.

Comentou que as comunidades ribeirinhas são muito participativas, mas que essa comunidade não participa muito. Acha que falta uma liderança que organize reuniões, sente que falta um empurrão, ou um presidente que tivesse tempo. Também comentou que crianças ribeirinhas trabalham muito, ajudam os pais na roça, na pesca, no trabalho dos pais.

\section{Manoel - Auxiliar Vespertino}

Funcionário do quadro efetivo da Secretaria de Educação há quatro anos, e nesta escola há dois anos, trabalha no horário vespertino, ficando responsável por fechar a escola e passar a chave do portão para o vigia. Senhor de aproximadamente quarenta e poucos anos, $1,68 \mathrm{~m}$, branco, muito falante, aguarda uma oportunidade para conversar, contar suas histórias, e demonstrar os conhecimentos que adquiriu exercendo outras profissões, tais como agente de saúde, comerciante, vigia, vendedor ambulante, secretário, pesquisador, etc.

Possui o Ensino Médio completo e manifestou interesse em prestar o vestibular, mas alega falta de tempo para se preparar, pois possui um pequeno comércio em sua residência, e disse que também trabalha como vigia noturno em uma empresa. Reside no bairro, em outra localidade, indo a pé para o trabalho.

Veste habitualmente bermudas compridas, camisetas e chinelos de dedo. Segundo a diretora, é uma pessoa disponível, com quem se pode contar. Sente-se em uma posição vantajosa em relação aos demais colegas por ser efetivo, procurando ser colaborador, mas evitando meter-se no que não considera seu trabalho. Geralmente fica sentado no refeitório, quando não há o que fazer e, segundo relatos informais, quando começa a conversar, distrai-se e é preciso chamá-lo para fazer o serviço.

Demonstrou estar interessado em saber sobre esta pesquisa, e falar de suas experiências, sendo atencioso e receptivo à presença da pesquisadora, mas ao mesmo tempo, querendo atenção e receptividade.

Assume uma postura tradicional em relação a seu trabalho, ou seja, não se sente como um agente educacional, limitando-se a realizar as tarefas que lhe competem. Muito observador, ficava atento às aulas no refeitório, e quando lhe davam abertura, gostava de perguntar a opinião dos profissionais sobre vários assuntos, como se quisesse testar o conhecimento alheio, logo emitindo suas opiniões, críticas e sugestões, ora demonstrando querer dialogar, trocar saberes. Os colegas o consideram uma boa pessoa, apesar de chato. Considera que a relação da escola com a comunidade é boa, pois nesta não há nada além da 
escola e da horta, e é importante promover o Ensino Fundamental. Principalmente com relação à diretora, que é muito querida na comunidade. Quanto à participação, comentou que costumam participar das reuniões, tendo grande aproximação com a diretora, de quem gostam muito, lhe relatando em detalhes tudo que acontece na escola, "de uma lâmpada que deveria ser apagada e muito mais".

\section{Maria - Merendeira Júnior}

Senhora de 44 anos, aproximadamente 1,60m, feições caboclas, cabelos pretos, de fios grossos, à altura da nuca, presos quando está em serviço. Possui o Ensino Fundamental incompleto, e estava cursando a sexta série, curso supletivo.

Foi contratada no início do ano de 2008, por empresa terceirizada, especificamente destinada à contratação de merendeiras, com contrato de dois anos, em horário integral, entre sete e dezessete horas, percebendo um salário mínimo. Está sempre de uniforme: camiseta branca, avental e touca na cabeça, com o símbolo da empresa. A carga horária de trabalho para as merendeiras é de 8 horas, com intervalo de uma hora para almoço, que efetivamente não aconteceu durante o período de realização desta pesquisa.

Mora na comunidade, bem próximo à escola, ficando responsável pelas chaves do portão e da cozinha. Conforme seu relato, à época da inauguração, trabalhou por oito meses como voluntária. Era sozinha, fazia a merenda e a limpeza, "e até dava tempo de fazer o crochê", acrescentando que ficava tudo limpinho e brilhando, pois "naquele tempo ainda tinha cera". Como precisava sustentar os filhos e por desentendimentos, teve que correr atrás de um trabalho remunerado. Informou que passou um ano vendendo salgados nas portas das casas, doces, fazendo faxina, capinando, o que aparecesse. Quando a escola foi contemplada com o cargo de merendeira, ela foi indicada pela diretora.

Em seu depoimento, comentou que o trabalho não é simples, o espaço é pequeno e muito quente; há rigidez com relação à higiene e conservação dos alimentos, e um cardápio a ser seguido, além do controle sobre a distribuição da merenda, tendo que anotar a quantidade diária servida. Reclamou da falta de temperos, informando que de vez em quando pede verduras aos pais que trabalham na horta. Passava a maior parte do tempo na cozinha, de onde podia observar tanto o movimento do refeitório e das salas de aula, como o entorno da escola.

Vindo do interior com cinco filhos e sem ter onde morar, foi bem recebida pela comunidade, que lhe abrigou e ajudou na construção de sua casa. Sente-se responsável pelos alunos, no dever de cuidar deles, corrigir, chamar atenção quando acha necessário, e de informar os pais sobre qualquer problema, crescendo como liderança junto à comunidade. 
Gosta de conversar, e do status que adquiriu na comunidade, em função de ser de confiança da diretora. Procura corresponder, atendendo às solicitações de quem "exige pedindo, mas sabe quando tem que exigir".

Demonstrou receptividade à pesquisa, procurando colaborar com as informações que tinha tanto a respeito da escola, como da comunidade. E também ponte entre a comunidade e a escola.

\subsection{A clientela}

A escola atende aos moradores da comunidade onde se localiza, e também de comunidades próximas, no bairro. Possui duzentos alunos, com idade entre cinco e doze anos, matriculados em oito turmas de educação infantil e primeiras séries do Ensino Fundamental. Há dois alunos ouvintes. Também deveria atender alunos de quatro anos, entretanto, segundo depoimento da diretora, em função da demanda e da falta de espaço, esta clientela ficou fora da escola.

Os alunos que residem perto da escola deslocam-se a pé e sozinhos, em geral em grupos de irmãos e primos, sem o acompanhamento de pais ou responsáveis. Observaram-se apenas duas mães moradoras da comunidade que conduziam diariamente seus filhos à escola. Os alunos provenientes das outras comunidades aguardam o transporte escolar, alguns sozinhos, outros acompanhados por um responsável. Há uma escala entre os professores para acompanhar o itinerário deste transporte ao levar e trazer os alunos para a escola, de modo que tenha sempre algum adulto junto com o motorista em todas as viagens.

O uniforme é cedido pela prefeitura e compõe-se de camiseta e bermuda. A camiseta é de malha, cor branca, e possui na frente uma tarja verde na altura do peito onde se inscreve o nome da prefeitura, e o símbolo da prefeitura acima da tarja. A bermuda é de cor verde com duas listras amarelas na lateral, e o símbolo da prefeitura no lado direito. Seu uso é obrigatório, mas não há rigidez, podendo utilizar o jeans. Os alunos não são impedidos de frequentar as aulas se não estiverem uniformizados, mas são avisados para este procedimento. Quanto aos calçados, estes variam entre tênis, sandálias e chinelos de dedo. Observamos que a maioria dos alunos possui mochilas, algumas já usadas por outros irmãos ou primos. Há um grupo pequeno de alunos que leva caderno e lápis na mão.

Em relatos informais com os agentes educacionais e nas observações realizadas no cotidiano, pudemos constatar que há problemas com relação à higiene e saúde, em parte dos alunos. Há os que apresentam boas condições de higiene, tanto corporal como com o material 
escolar. Mas há os que vão para a escola com roupas sujas ou mal lavadas, cabelos despenteados e maltratados. Há problemas com parasitoses e pediculose, manchas ou lesões na pele (de pitiríase a impetigem), ou feridas decorrentes de picadas de insetos, principalmente formigas (formiga de fogo ou jiquitaia), e malária. É comum justificativa de faltas por alguma doença.

Observou-se também a presença de alunos com necessidades educativas especiais junto aos demais alunos, sem a presença deste rótulo ou o título "inclusão escolar". $\mathrm{Na}$ expressão da diretora da escola, "aqui já ta tudo incluído”. Todos são considerados pela direção da escola como alunos, com e sem dificuldades, ou seja, há dificuldades em algumas tarefas, mas há facilidades em outras. Se por um lado necessitam de mais atenção, por outro não devem ser considerados como incapacitados. Também estão presentes as recomendações no sentido de não apontar a deficiência, e de rechaçar o bullying ${ }^{17}$. Apenas em uma turma, de $2^{\mathrm{a}}$ série, observou-se o comportamento agressivo dos alunos em relação a um aluno especial, com xingamentos e mesmo agressão física, geralmente na ausência do professor, mas também em sua presença, disfarçadamente.

Ainda segundo a diretora, os alunos são envolventes e "envolvíveis", de fácil relacionamento e com facilidade para aprendizagem, mas é preciso estar disponível para relacionar-se com eles no seu tempo, na sua dinâmica. Em conversas informais, comentou que há alguns alunos que apresentam dificuldades, o que é esperado, e que tem encontrado problemas com alunos oriundos de outras escolas, citando o caso de um aluno que veio transferido de uma escola urbana e que, embora matriculado na $3^{\mathrm{a}}$ série, freqüentava também as aulas da $1^{\mathrm{a}}$, em outro turno, pois não sabia ler nem escrever. Orgulha-se do trabalho desenvolvido, comentando sobre os alunos que estão na escola desde o primeiro período da Educação Infantil, e que estão bem mais adiantados. Citou haver muitos problemas na convivência familiar, e também haver alunos com necessidade de acompanhamento especializado, mas a maioria encontra-se em pleno desenvolvimento.

Em relação aos professores, apenas um tem um posicionamento próximo ao da diretora. Os demais concordam que os alunos possuem bastante dificuldade, sendo poucos os que conseguem bom êxito. Para eles, há os alunos de bom aprendizado e os fracassados. O insucesso escolar é atribuído à falta de acompanhamento por parte dos pais e a certas

\footnotetext{
${ }^{17}$ Bullying é o termo usado para designar todas as formas de atitudes agressivas, intencionais e repetidas, que ocorrem sem motivação evidente, adotadas por uma pessoa ou grupo contra outro(s), causando dor e angústia, e executadas dentro de uma relação desigual de poder. Pode se dar por agressão física, intimidação, discriminação, humilhação ou através de gestos.
} 
características individuais e culturais da criança rural. Alguns alunos são apontados pelos professores como desinteressados.

Outro aspecto apontado indica ser o ambiente escolar muito diferente do que estão acostumados, diferente das experiências que vivenciam fora da escola, onde não há livros nem ambiente favorável ao aprendizado acadêmico. Os professores também concordam que há problemas na convivência familiar.

Relataram possuir dificuldades em lidar com determinados alunos, cujos problemas, sejam individuais, familiares ou sociais, lhes incluem nos cuidados especiais, indicando a necessidade de especialistas ou pelo menos cursos de aperfeiçoamento docente. Reconhecem, entretanto, que as famílias não têm condições financeiras para levar os filhos ao centro municipal de atendimento a aluno especial, e que estes não podem ficar fora da escola.

Dos problemas existentes, os professores destacam a infrequência e indisciplina como os que mais interferem no seu trabalho e no aprendizado.

Em relação à frequência, os diários dos professores indicam que houve um índice significativo de ausências durante o período escolar. A primeira série, por exemplo, tendo dezoito alunos matriculados, a partir do mês de agosto, tinha uma frequência média de nove alunos. Os professores informaram que há casos de pais que passam semanas trabalhando em sítios mais afastados, e nestes períodos, os filhos faltam aulas. Em outros casos, quando questionaram os pais sobre os problemas de frequência, alguns relataram que saem cedo para o trabalho e deixam os filhos em casa, às vezes sob recomendação de um vizinho ou parente, mas não tem como controlar se os mesmos vão ou não para a escola.

No contato com os alunos, constatamos alegria e vivacidade, curiosidade, atenção ao aprender, e resistência aos conteúdos escolares, quando apresentados no modelo escolar tradicional, ou seja, exercícios, cópias, provas. A resistência em atender às exigências estabelecidas manifestava-se com a dispersão ou com estratégias como pedir para ir ao banheiro, para auxiliar o colega ou ainda para apontar o lápis frequentemente quebrado.

Os alunos provam que sabem, quando lhes oportunizam situar o conhecimento aprendido nas atividades de seu cotidiano fora da escola, mesmo em situações dentro da escola. Mas, tão pequenos, já carregam o fardo do "não sei, ta difícil, não consigo aprender".

Observou-se que, de modo geral, apresentam bom relacionamento entre si. Mas há comportamentos bastante agressivos. Há alguns grupos organizados por parentesco e vizinhança, e as rixas familiares se fazem presentes na escola, manifestando-se nos momentos de menor controle. Quando circulam livremente, alguns alunos são agressivos, com xingamentos e mesmo agressões físicas. Segundo informações dos agentes institucionais, 
refletem o modo agressivo como os pais os tratam, já tendo ocorrido casos de abuso e espancamento. Foi em relação a este problema que a escola adotou como método o Projeto Temático "escola-família-comunidade", objetivando promover a integração escola/família/comunidade, e promover o questionamento do modo como pais se relacionam com os filhos, sensibilizando e apoiando para o cuidado.

Em relação aos moradores, a maioria possui o Ensino Fundamental incompleto, havendo atualmente mães que estão continuando os estudos em cursos supletivos. A idade varia entre 17 e 64 anos, estando predominantemente na faixa entre 25 e 34 anos. Consideram que os filhos são inteligentes, espertos, enfatizando bons resultados nos trabalhos escolares, mas principalmente como aprendem e resolvem as situações cotidianas ou ainda as "danações de menino". Por outro lado, reconhecem que alguns têm dificuldades na escola. Isto, em parte, é admitido como algo natural, e em parte, questionado, pois "como pode o filho ser inteligente só em casa". Consideram que ter uma escola na comunidade é muito importante, pois agrega valor social, estreita relações com outras comunidades e promove segurança e comodidade. Mesmo que não atenda às necessidades de todos os moradores, visto que só contempla a primeira etapa do Ensino Fundamental, eles acham bom ter uma próxima à residência e falam da necessidade de sua ampliação. Informam que a escola faz a diferença, e trouxe contribuições significativas para a comunidade. Atribuem à escola um bom conceito, e à diretora todas as conquistas conseguidas para a escola, bem como a apoio a certos empreendimentos da comunidade, considerando-a pessoa acolhedora, bastante dedicada ao trabalho e aos alunos. Todos os pais com os quais se estabeleceu uma conversa, quer informalmente, quer nas entrevistas foram unânimes em elogiar o trabalho da diretora. Entretanto, em relação aos professores, há os que são considerados "bons professores", os que são "bons, mas grosseiros", e há os que são "fracos".

Os pais, em sua maioria sujeitos da escola rural, levam consigo as marcas de sua história escolar e das interações numa sociedade letrada. Relataram que na passagem pela escola, não obtiveram êxito, aprendendo a assinar o nome e algumas poucas coisas. Fazem referência às possibilidades que a escola pode trazer para seus filhos, em termos profissionais, comparando com a vida que possuem. Ressentem-se por mal saber ler e escrever e por seus pais não tê-los estimulado a permanecer na escola. 


\subsection{Distribuição de turmas, turnos e horários.}

No ano de 2008, a escola possuía cento e noventa e oito alunos matriculados e dois alunos ouvintes, distribuídos em oito turmas, funcionando em três turnos: matutino, intermediário e vespertino, dentro de dois modos de divisão: cinco turmas no Ensino Fundamental de primeira a quarta série, e três turmas no ensino fundamental de nove anos, assim distribuídos:

Tabela 2 - Distribuição das turmas no ano 2008.

\begin{tabular}{|c|c|c|c|c|c|}
\hline Turno & Horário & Sala & Série & $\mathbf{N}^{\mathbf{0}}$. alunos & Total \\
\hline \multirow{3}{*}{ Matutino } & \multirow{3}{*}{$7: 30-10: 30$} & Sala 02 & $2^{\circ}$ ano/ciclo & 23 & \multirow{3}{*}{66} \\
\hline & & Sala 01 & $2^{\mathrm{a}}$ série & 25 & \\
\hline & & Refeitório & $1^{\mathrm{a}}$ série & 18 & \\
\hline \multirow{2}{*}{ Intermediário } & \multirow{2}{*}{$10: 30-13: 30$} & Sala 02 & $1^{\circ}$ ano/ciclo & 33 & \multirow{2}{*}{57} \\
\hline & & Sala 01 & $3^{\mathrm{a}}$ série & 24 & \\
\hline \multirow{4}{*}{ Vespertino } & \multirow{3}{*}{$13: 30-16: 30$} & Sala 02 & $2^{\circ}$ período & 30 & \multirow{3}{*}{75} \\
\hline & & Sala 01 & $3^{\mathrm{a}}$ série & 28 & \\
\hline & & Refeitório & $2^{\mathrm{a}}$ série & 17 & \\
\hline & & & & Total: & 198 \\
\hline
\end{tabular}

A existência do turno intermediário justificava-se, segundo a diretora da escola, pela demanda de alunos. Informou que cerca de trinta crianças com quatro anos, residentes na comunidade e arredores, ficaram fora da escola. Também informou que aceitou matricular duas turmas além da capacidade da escola, em virtude de um contrato verbal feito no final do ano 2007 com os diretores do centro social, cuja sede localiza-se no terreno da escola. Entretanto, no início do ano, o contrato não foi firmado e já havia alunos matriculados. Solicitou a intervenção da Secretaria de Educação para negociar o espaço ou buscar alternativas, mas não houve resultado favorável. Assim sendo, recorreu ao horário intermediário. Constatamos que o recurso ao horário intermediário também foi utilizado no ano anterior.

Não houve em 2008 aulas de educação física. A argumentação principal é de que não havia espaço físico, em função do uso do refeitório como sala de aula, além de não poder utilizar a área externa em virtude do calor e insolação. Os alunos eram mantidos no espaço construído, não havendo possibilidades para recreação ou atividades livres, com rigor no controle da disciplina, exceto nos dias em que havia algum evento.

As atividades foram predominantemente desenvolvidas nas salas de aula, a partir dos projetos desenvolvidos pelos professores, com base no Projeto Temático da escola e no PRORED - o Programa de Redimensionamento da Educação Básica, da Secretaria Municipal 
de Educação. O Projeto Temático relaciona-se à metodologia utilizada pela escola: a Pedagogia de Projetos, uma metodologia de trabalho educacional que objetiva organizar a construção dos conhecimentos em torno de metas previamente definidas, de forma coletiva. Envolve preparação, execução e a culminância, onde se avalia os trabalhos programados e desenvolvidos, sempre com a participação do aluno e coletivamente.

A escola não possuía projeto político pedagógico no período em que se realizou a coleta de dados. Conforme relato da diretora, isso se deve ao fato de não ter ato de criação. A escola estava impossibilitada em relação a vários procedimentos, inclusive receber recursos. Com o ato de criação, em julho/2008, a escola pode constituir o conselho escolar, e participar de outros processos; entretanto, não se observou nenhum movimento objetivando a produção do projeto pedagógico. Conforme relato da direção, o ano foi bastante tumultuado, em função dos concursos e prestações de contas, e não foi possível organizar o projeto.

A escola também participou e organizou palestras e eventos, conforme estabelecido pela Secretaria Municipal de Educação, dentre elas, o Dia da Devolução do Livro Didático, a Semana do Portador de Necessidades Especiais, a Semana de Combate à Violência Sexual Infantil, a Semana Nacional de Ciência e Tecnologia e a entrega do prêmio Plugado no Saber. Alguns destes eventos foram realizados sem discussão e participação dos professores no planejamento. A participação em eventos fora da escola abrangia apenas pequena quantidade de alunos, escolhidos pelos professores em função do comportamento e mérito.

Houve várias substituições no decorrer do primeiro semestre letivo, ocasionando diversas trocas de professores nas turmas. O quadro abaixo apresenta o detalhamento destas alterações:

\begin{tabular}{|c|c|c|c|c|c|c|}
\hline Turmas & Fev-abr & Abril & Mai-Jun & Jul-Ago & Set & Out-Dez \\
\hline $2^{\mathbf{o}}$ ano & Prof. Sônia & Prof. Sônia & Prof. Sônia & Prof. Bia & Prof. Bia & Prof. Bia \\
\hline $1^{\text {a }}$ série & $\begin{array}{c}\text { Prof. Lúcia/ } \\
\text { Helen }\end{array}$ & Prof. Lúcia & $\begin{array}{c}\text { Prof. Lúcia / } \\
\text { Jacó }\end{array}$ & Prof. Jacó & Prof. Jacó & Prof. Jacó \\
\hline $2^{\text {a }}$ série & Prof. Diva & Prof. Edmar & Prof. Edmar & Prof. Edmar & Prof. Edmar & Prof. Edmar \\
\hline & & & & & & \\
\hline $1^{\text {o } a n o ~}$ & Prof. Sônia & Prof. Sônia & Prof. Jacó & Prof. Bia & Prof. Bia & Prof. Bia \\
\hline $3^{\text {a } \text { série }}$ & Prof. Lúcia & Prof. Edmar & Prof. Edmar & Prof. Edmar & Prof. Edmar & Prof. Edmar \\
\hline & & & & & & \\
\hline $2^{\text {o }}$ período & Prof. Helen & Prof. Diva & Prof. Diva & Prof. Jacó & Prof. Jacó & Prof. Jacó \\
\hline $2^{\text {a } \text { série }}$ & Prof. Diva & Prof. Ana & Prof. Ana & Prof. Ana & Prof ...*/Bia & Prof. Diva \\
\hline $3^{\text {a } \text { série }}$ & Prof. Lúcia & Prof. Edmar & Prof. Edmar & Prof. Edmar & Prof. Edmar & Prof. Edmar \\
\hline Apoio M. & --- & --- & Prof. Lúcia & Prof. Lúcia & Prof. Lúcia & \\
\hline Apoio T. & --- & --- & --- & Prof. Diva & Prof. Diva & \\
\hline
\end{tabular}

Quadro 6 - Rotatividade dos professores nas turmas durante o ano 2008

\footnotetext{
* As reticências utilizadas no mês de setembro indicam que durante duas semanas os alunos ficaram sem professor.
} 
Assim sendo, o ano letivo iniciou com três professores contratados (Professoras Diva, Sônia, Helen) e um concursado (Professora Lúcia), terminando com quatro professores concursados (Professores Bia, Jacó, Edmar e Lúcia) e um contratado (Professora Diva). A professora Ana esteve na escola no período entre abril e setembro, quando solicitou sua transferência para uma escola próxima à sua residência, alegando motivos de saúde e dificuldades de deslocamento.

Conforme relatos de professores, direção e pais de alunos, isto interferiu significativamente no processo de ensino-aprendizagem e no andamento das atividades da escola.

\section{A Merenda}

A merenda do dia é preparada pela merendeira no início da manhã, conforme o cardápio, em panelões de alumínio, e servida em pratos e/ou canecas de plástico resistente, na cor azul marinho. O cardápio, produzido pela equipe de nutricionistas da Secretaria de Educação, deve ser seguido por todas as escolas. Compreende pão, bolachas, frutas, leite, suco, mingau de arroz. O abastecimento é feito por outra equipe da Secretaria, responsável pela aquisição e distribuição da merenda escolar.

O controle de distribuição da merenda é feito mensalmente, através do preenchimento de dados estatísticos em um relatório padronizado para todas as escolas. A merendeira fica responsável por anotar diariamente o que é feito, que material foi utilizado e a quantidade. Também deve anotar quantas refeições foram servidas e quantos alunos receberam a merenda em cada dia. Observou-se que para o preenchimento deste formulário, a merendeira é auxiliada pela agente operacional.

A merenda era servida uma vez por turno, em horário fixo, às nove horas no turno matutino; doze horas no turno intermediário e quinze horas no turno vespertino. Constatando que esta é a primeira refeição do dia para muitos alunos, e que há sobra de merenda, a diretora, por sua responsabilidade, decidiu incluir o café para os alunos do turno matutino, em geral uma caneca de leite com pão ou bolachas. Conforme relatou, se o diretor quiser, dá para oferecer o café, pois muitos alunos faltam e sempre sobra merenda. Se houver interesse e vontade administrativa, é possível fornecer o café.

Os professores são avisados quando a merenda fica pronta e liberam os alunos, que se dirigem ao balcão para receber uma caneca com leite, suco ou mingau, e pão ou bolachas. Depois seguem para as mesas, sentando-se em pequenos grupos de amiguinhos ou parentes, promovendo alguma brincadeira, como ver quem pega mais rápido um objeto colocado à 
mesa, ou jogar biscoito para o alto e pegar com a boca. Observaram-se no turno intermediário alunos do sexo feminino que sentam sempre juntos e andam de mãos dadas. Também se observou no turno matutino um aluno que só sai da sala para receber a merenda e retorna rapidamente, não se relacionando com os demais.

Há uma balde à frente do balcão, para que os alunos possam colocar os copos ou pratos após merendarem.

O intervalo da merenda é curto, não há tempo para se fazer muita coisa além de comer a merenda. Os professores aproveitam para circular, ir à secretaria ou ao toalete. Não há espaço para que as crianças se dispersem, e a ordem é parcialmente estabelecida pelos professores, cada um responsável por sua turma, em geral através de coerção. Não se permite correria no refeitório. Quando isto ocorre, ou quando o zum-zum-zum fica alto demais, o professor chama atenção dos alunos, e os conduz para a sala de aula. Ainda assim, o burburinho é grande, os alunos conversam, riem, brincam, e também se agitam, principalmente no turno matutino e nos dias mais quentes.

Os professores raramente comem a merenda dos alunos. Fazem uma cota para a compra de mantimentos para o preparo do almoço. Além deles, a diretora, a agente operacional, o motorista e um vigia. A professora de apoio fica responsável em recolher o dinheiro de cada um e comprar os mantimentos. O cardápio é decidido diariamente, conforme o recurso financeiro e a disponibilidade de alimentos à venda nos mercados do bairro. $\mathrm{O}$ almoço era feito pela merendeira e, algumas vezes por um professor. Embora gostem bastante de peixe, concordam quanto à inviabilidade de seu preparo na escola. O horário de almoço é curto, pois dois professores estão em sala de aula e logo em seguida devem servir a merenda dos alunos.

\section{Uma rápida descrição do horário}

O horário matutino inicia-se às sete horas e trinta minutos. Professores e alunos entram nas salas de aula, organizam o material, e os professores retornam ao refeitório para tomar café, que dura em torno de dez a quinze minutos. O intervalo para merenda dos alunos acontece às nove horas e dura em torno de dez a quinze minutos. Os alunos merendam e retornam imediatamente para as salas. Às dez horas e vinte minutos, professores e alunos preparam-se para sair, pois o ônibus escolar fará o percurso levando os alunos do turno matutino e trazendo os do turno intermediário. Aproximadamente às dez horas e cinqüenta minutos o ônibus chega, e os alunos dirigem-se para as salas. Há duas turmas neste horário. Aproximadamente ao meio-dia, servem o almoço dos professores. Não há intervalo para 
descanso, almoçam e voltam para as salas. Os alunos permanecem sozinhos nas salas de aula, realizando alguma tarefa deixada pelo professor. Logo após o almoço dos agentes institucionais, a merenda aos alunos é servida. Às treze horas e vinte minutos, os alunos preparam-se para entrar no ônibus. Aproximadamente às treze horas e cinqüenta minutos os alunos estão em sala de aula para o turno vespertino. A merenda é servida às quinze horas e às dezesseis horas e vinte minutos o ônibus já está acionado para que todos possam ir embora.

\subsection{Metodologia de ensino}

Segundo informações da diretora e conforme fontes documentais encontradas nos arquivos, a escola "prima por um ensino de qualidade, compreendendo que a interação escola-família é um dos fatores primordiais para que haja um bom desenvolvimento do alunado em todos os aspectos: cognitivo, emocional, o que se torna fundamental para uma educação, deveras de qualidade ${ }^{18, "}$.

A visão e missão da escola foram estabelecidas pela Gestão da Secretaria Municipal de Educação em vigência à época. Tem como visão, “ser reconhecida como uma instituição educacional dinâmica, comprometida com a formação de cidadãos plenos, críticos, éticos e conscientes, cumprindo a responsabilidade social e respeitando as diferenças".

A missão da escola, escrita em uma faixa e afixada no refeitório, “é promover o ensino da língua materna, de modo a introduzir o aluno no mundo da escrita, tornando-o um cidadão funcionalmente letrado, garantindo o domínio da linguagem, necessário para o exercício da cidadania".

A escola trabalha com a Pedagogia de Projetos, ou seja, projetos de ensino e aprendizagem. Na opção por esta metodologia, a diretora da escola entende ser um caminho para transformar o espaço escolar em um meio estruturado, aberto à construção de aprendizagens significativas para todos que dele participam, além de ser uma forma de trabalhar conhecimentos de forma interdisciplinar.

A Pedagogia de Projetos tem por fundamento o desenvolvimento de projetos da vida cotidiana, baseados na decisão coletiva, inclusive levando em consideração as idéias dos alunos, mediadas pelos professores "rumo ao aprendizado e ao sucesso de todos". Nesta proposta, o próprio aluno constrói o conhecimento, com base em descobertas espontâneas e significativas, através de situações de ensino apenas propostas pelo professor. Os temas

\footnotetext{
${ }^{18}$ Informações obtidas junto ao Projeto Temático 2008.
} 
partem das necessidades/desejos do grupo percebidos pelo(a) professor(a), a quem cabe o papel de mediador(a) na sala de aula, ou seja, vai viabilizando e organizando o trabalho através de constantes observações da turma para, assim, perceber o que está despertando o interesse das crianças.

O ensino se dá pela problematização e pela articulação dos saberes escolares com os saberes sociais. A metodologia, flexível e participativa, prima pelo contato direto do aluno com a realidade e a contextualização dos conteúdos. Envolve como etapas a escolha do tema, a problematização, a pesquisa ou produção, e a culminância ou etapa final do processo de avaliação.

Nessa proposta não existem temas que não possam ser abordados, nem limites/limitações para aprender. A relação ensinar-aprender deixa de ser transmitir conteúdos e copiar/memorizar, para se valorizar a participação, a construção coletiva, a vivência de sentimentos e a tomada de decisão. Caracterizada por sua flexibilidade e complexidade, impõe exigências elevadas aos professores, sendo deles exigido um conhecimento que vai além de uma única área de formação.

Conforme dados obtidos nos documentos escritos pela diretora e em seus depoimentos, a proposta pedagógica da escola em estudo tem como referência as bases teóricas fundamentadas na perspectiva da construção do conhecimento e no sociointeracionismo, procurando valorizar a atividade mental construtiva nos processos de aquisição de conhecimentos. Assim, entende que o desenvolvimento individual é um processo em que o aluno deve atuar. $\mathrm{O}$ erro deve ser considerado parte deste processo, devendo o professor estimular os avanços dos alunos. A diretora considera com isso, que pode obter e tem obtido resultados bastante favoráveis com a pedagogia de projetos.

Sob esta perspectiva, elaborou o Projeto Temático, documento-base para a realização de todas as atividades da escola durante o ano.

O Projeto Temático 2008 foi produzido pela diretora, consultando as professoras que estavam na escola desde o início do ano, e os projetos de anos anteriores, objetivando com isso dar seguimento à proposta que vem sendo desenvolvida desde a inauguração da escola. $\mathrm{O}$ documento em quinze páginas contém uma pequena justificativa, os objetivos e a relação de conteúdos a serem trabalhados nas diferentes séries/anos. Os conteúdos estão organizados em quatro áreas de conhecimento: Matemática, Língua Portuguesa, Estudos da Sociedade e da Natureza, e Artes. Após os conteúdos, apresenta os procedimentos metodológicos e critérios de avaliação. Ao final, uma mensagem intitulada "quando educas", sem referência ao autor. 
O Projeto Temático 2008 estabeleceu como meta a relação família-escolacomunidade, enfatizando a vivência no cotidiano das famílias, a ampliação da participação na escola, o estímulo à relação das famílias com a aprendizagem dos alunos, o exercício de direitos, deveres e da solidariedade, além do estímulo, sensibilização e desenvolvimento das habilidades de leitura e escrita. De acordo com este documento, a escola se propõe a sensibilizar e conscientizar quanto à importância do envolvimento dos pais no processo de aprendizagem dos filhos, considerando a importância desta participação para melhor desempenho dos alunos; deve conduzir os alunos a participar da vida em comunidade, tendo em vista seu papel social de formar cidadãos plenos, críticos e éticos, conscientes de seus direitos e deveres, e construtores de seus saberes. Também enfatizou a ação transformadora e o papel político na luta contra as desigualdades sociais, onde se deve assumir a responsabilidade de um ensino para capacitar os alunos na conquista da participação social, cultural e reivindicação social.

Conforme estabelecido neste documento, as ações pedagógicas deveriam ser desenvolvidas em três bimestres letivos, podendo ser prorrogadas, se necessário, desdobrando o tema central em vários subtemas, os mesmos para as diferentes séries, considerando objetivos e conteúdos estabelecidos pelo PRORED para cada série/ano. Assim, com base no Projeto Temático 2008, cuja versão definitiva ficou pronta em maio, cada professor deveria estabelece subprojetos contemplando conteúdos das quatro áreas de conhecimento, de duração mensal ou mais, em casos de não assimilação concreta dos conteúdos. Não houve exigência da apresentação de plano de ensino, apenas dos subprojetos mensais, ficando aqueles a critério da organização pessoal de cada professor. Para sua abordagem, devia contemplar a utilização de textos contextualizados, com títulos concernentes ao subtema escolhido, tendo cada um, a duração de uma semana, e a adoção de técnicas de pesquisa bibliográfica, pesquisa de campo, cartazes, painéis, maquetes, dramatizações e outros eventos. O quadro abaixo apresenta os títulos dos subprojetos desenvolvidos e dos principais textos utilizados no período entre março e setembro, que foram disponibilizados por escrito: 


\begin{tabular}{|c|c|c|}
\hline Mês/meses & Subprojeto & $\begin{array}{c}\text { Temas dos textos-base } \\
\end{array}$ \\
\hline \multirow[b]{2}{*}{ Março e abril } & $\begin{array}{c}\text { Quem sou eu } \\
\text { (turmas do } 2^{\circ} \text { período e } 1^{\circ} \text { ano) }\end{array}$ & $\begin{array}{l}\text { - Crianças devem ir à escola } \\
\text { - Amigos do peito } \\
\text { - Gente tem sobrenome }\end{array}$ \\
\hline & Eu e a escola & $\begin{array}{l}\text { - Minha escola é muito legal } \\
\text { - O dia-a-dia na escola } \\
\text { - As primeiras escolas do Brasil } \\
\text { - Vida de índio } \\
\end{array}$ \\
\hline \multirow[b]{2}{*}{ Maio } & Eu e minha família & $\begin{array}{l}\text { - Crianças devem ir à escola } \\
\text { - Os membros de uma família } \\
\text { - Outras famílias }\end{array}$ \\
\hline & $\begin{array}{c}\text { Eu e minha família } \\
\text { (turmas de } 2^{\mathrm{a}} \text { e } 3^{\mathrm{a}} \text { séries) }\end{array}$ & $\begin{array}{l}\text { - Muito antes de nascer } \\
\text { - Estatuto da criança e do adolescente } \\
\text { - Diferentes organizações familiares } \\
\text { - A família e o trabalho infantil }\end{array}$ \\
\hline Junho & Meio ambiente & $\begin{array}{l}\text { - Água } \\
\text { - Seres vivos e não vivos } \\
\text { - A importância da floresta } \\
\text { - Respeito à natureza } \\
\end{array}$ \\
\hline Julho & Valorização do idoso & $\begin{array}{l}\text { - Feliz quem tem vovó } \\
\text { - Respeito ao idoso } \\
\text { - Estatuto do idoso } \\
\text { - Origem do dia da avó }\end{array}$ \\
\hline Agosto & A família e a promoção à saúde & $\begin{array}{l}\text { - Necessidades educativas especiais } \\
\text { - Esporte e saúde } \\
\text { - Atitudes que ajudam a manter a higiene } \\
\text { saudável }\end{array}$ \\
\hline Setembro & Ética na política & $\begin{array}{l}\text { - Cidadania } \\
\text { - Desfile cívico } \\
\text { - A política } \\
\text { - Desigualdade social } \\
\end{array}$ \\
\hline
\end{tabular}

Quadro 7 - Temas dos subprojetos desenvolvidos no ano 2008.

Os subprojetos também contemplaram datas cívicas e comemorativas, e as Semanas Temáticas estabelecidas no calendário escolar da Secretaria Municipal de Educação, dentre elas a Semana de Combate à Violência Sexual Infantil, no mês de abril, a Semana do Portador de Necessidades Educativas Especiais, a Semana do Trânsito em agosto, e a Semana da Pátria. Houve questionamentos por parte de alguns professores quanto à realização destas atividades, por considerar que a Secretaria fere o princípio da autonomia das escolas e dos docentes, ao incluir arbitrariamente novas Semanas no calendário acadêmico, já em execução, sem consulta aos envolvidos, e sem conhecimento e/ou consideração das especificidades locais.

Como culminância, objetivando avaliar as habilidades adquiridas pelos alunos no decorrer do processo, o projeto geral da escola estabeleceu a realização de eventos no final de cada subprojeto. Foram eles: o Dia das Mães, a Semana do Meio Ambiente, o Dia da Avó, a Semana do Transito, o Dia do Folclore, a Semana da Pátria, a Semana da Ética na Política e o Dia da Família. Além destes, o Dia do Estudante e a Semana da Criança constituíram-se em 
eventos comemorativos, dedicados a atividades de lazer. Para estes momentos, um professor ficava responsável por sua organização, e os demais professores deviam trabalhar com seus alunos alguma apresentação.

A temática ambiental atravessou práticas e conteúdos curriculares, mas de modo geral, não se apropriou do conhecimento da comunidade, ou o fez de forma desconectada. $\mathrm{O}$ ambiente ao redor foi pouco solicitado. Temas como violência sexual infantil, exploração do trabalho infantil, ou doenças sexualmente transmissíveis, são considerados pela diretora e por alguns professores como excelentes oportunidades para desenvolver estratégias de ação junto à comunidade. Entretanto, a apresentação da temática ambiental ainda esteve restrita ao temas natureza, água, lixo, fazer uma horta ou plantar árvores, ou melhor, "não plantar porque senão a comunidade destrói tudo".

Temas da atualidade, e outros, como direito à família, direito à escola, foram abordados, seja através dos textos utilizados, ou como componentes dos conteúdos curriculares, nas explicações dos professores. Observou-se que os textos mais críticos foram introduzidos pelos professores que assumiram as turmas de $2^{\mathrm{a}}$ e $3^{\mathrm{a}}$ séries.

Também se constatou que os subprojetos eram semelhantes, independente das séries, e alguns, embora destinados a séries diferentes, apresentavam, os mesmos registros no que diz respeito aos objetivos operacionais, estratégias docentes, dinâmicas de apresentação e parte dos conteúdos. Os professores recém-chegados, com base em um dos subprojetos escrito por uma professora que está na escola desde anos anteriores, compuseram suas propostas, dentro do que consideravam ser de interesse ou necessário aos alunos. Não houve participação dos alunos na proposta ou elaboração de nenhum subprojeto.

Houve reuniões mensais destinadas ao planejamento conjunto das atividades. Em geral, era um momento coletivo em que a diretora participava, com informes e discussões que envolvessem questões gerais e divisão de tarefas. Em outros momentos, os professores se organizaram em duplas, conforme as séries aproximadas, ou seja, professores da primeira série e segundo ano, e professores da segunda e terceira séries. Observou-se, durante o segundo semestre, que o planejamento consistia em encaixar os conteúdos obrigatórios das séries nos subprojetos, além de planejar as atividades para a culminância e para as semanas temáticas. Em relatos informais e nas entrevistas, os professores informaram que os temas devem surgir das necessidades dos alunos, entretanto, isto não ocorreu. Por outro lado, houve vários momentos informais de conversas, troca de experiências e planejamento de atividades, como no planejamento das atividades para o dia do estudante e a semana do folclore, que aconteceu enquanto os alunos assistiam a uma palestra. 
Procurando fugir às concepções tradicionais, a direção da escola verbaliza a necessidade de uma prática participativa, abrindo espaço para uma perspectiva dialógica, para o envolvimento da e com a comunidade e para questionamentos, o que é bem visto pelos pais, principalmente no que diz respeito à diretora, vista como acolhedora e, consequentemente, acolhida. A escola procura estimular a relação pai-aluno, no sentido do acompanhamento por parte dos pais, da vida escolar de seus filhos, do cuidado e da qualidade das relações afetivas. Entretanto, constatamos que a proposta metodológica estabelecida pela direção não foi privilegiada: os professores cumpriam tarefas, dentro dos temas estabelecidos, e escrevendo projetos mensais, mas em sala de aula, prevalecia o método de cada professor, predominantemente tradicional.

Houve também desentendimentos entre dois professores e a diretora, pois aqueles consideravam que uma metodologia não deve ser imposta pela direção. Conforme relato de um dos professores, cada professor deve poder definir seu próprio método, a partir de suas experiências e da relação que vai estabelecer com a turma. Uma professora reivindicava a autonomia do trabalho pedagógico, conclamando os colegas a se manifestar e exigir o que considera um direito. Também argumentou que não concordava em retirar os alunos de sala de aula apenas para cumprir o estabelecido em um planejamento, sem ter clareza dos objetivos e do que isso significa para o processo de aprendizagem.

\footnotetext{
"Saviani, quando ele trabalha a questão da escola, ele diz que em uma atividade desenvolvida tem que ver a questão do amadurecimento. Se for pra tirar o aluno de dentro da sala de aula e por quadra, ele fala assim, apenas pintar o rosto, sem dizer por que é que eles estão representando o índio, que é o primeiro que habitou este país, e tudo que o índio sofreu, então essa atividade não vai ter valor nenhum. Então nesse ponto eu concordo com ele. Tiramos muito o aluno de dentro da sala, pra coisas que eu acho que não tem significado" (Profa. Ana).
}

Estes desentendimentos puderam ser explicitados em momentos de conversa entre a diretora e os professores, mas não conduziram a modificações no que já havia sido estabelecido. Apesar de questionamentos e relutância por parte de dois professores em desenvolver as atividades do modo sugerido pela diretora, esta não abriu mão de determinadas atividades, nem da execução de subprojetos anteriormente estabelecidos ou pelo menos de seu registro.

A construção de estratégias para "atingir" os alunos com dificuldades foi outro tema sugerido em vários momentos, predominantemente atravessado por uma concepção tradicional, apoiada na ideia de que as falhas no processo de aprendizagem devem-se, 
principalmente, a dificuldades individuais e à cultura rural, e de que medidas médicocompensatórias são necessárias. Mas também observamos inquietações acerca desta própria concepção, levando os professores a questionar e buscar apoio externo.

Em relação à participação e envolvimento da comunidade no processo de aprendizagem, foram previstas palestras e reuniões mensais, por turma, que se restringiram a três reuniões, em que pais, chegando "a conta-gotas", conversavam com os professores e assinavam o boletim. Interessante destacar que a importância do envolvimento com a aprendizagem, a amorosidade, a violência e negligencia familiar foram temas recorrentes em vários momentos em que pais, individual ou coletivamente, estiveram presentes na escola. Nos eventos promovidos pela escola, a participação estava limitada à condição de expectador, e quando convidado. Para o estímulo à participação, estabeleceram premiações e promoções, como escolha da família nota 10 , distribuição de brindes, lembranças e lanche. Considera-se como envolvimento efetivo dos pais na aprendizagem dos alunos, aquele que, quando solicitado, responde ao chamado da escola, e "busca informações quanto ao desempenho, progressos e dificuldades".

\subsection{Descrição de um dia escolar}

Em torno das sete horas e dez minutos, o transporte escolar chega ao bairro, e pára em alguns pontos, desde a estrada principal, para recolher alunos. Pára também em um mercado, na Vila, a fim de que os professores possam comprar alimentos para o café da manhã. Circula, contorna e segue para a escola, lá chegando entre sete e vinte ou sete e vinte e cinco horas.

A escola já se encontra aberta. A merendeira, que mora próximo, ficou responsável por receber a chave do vigia, abrir a escola, preparar uma garrafa de café e a merenda. A auxiliar de serviços gerais inicia suas atividades às sete horas, e à chegada do transporte escolar, salas e refeitórios devem estar limpos.

Não há fila para entrar. Os alunos que moram na comunidade vão chegando e aguardando no refeitório a chegada dos professores. Alguns alunos, às vezes, entram na sala 01 para guardar o material, mas se houver algazarra, a merendeira chama todos de volta para o refeitório. Neste momento, é possível observar comportamentos livres, os alunos brincam, correm, divertem-se.

Com a chegada do ônibus, todos vão descendo e se dirigindo para o refeitório e para as salas de aula. Os alunos saem correndo, entre brincadeiras, passos calmos, passos largos, tropeços e empurrões, embalados por vozes que pedem para ter calma e não correr. A 
diretora ou a agente operacional pega a chave e abre a diretoria. A porta da sala 01 está sempre aberta, os alunos entram. À porta da sala 02, geralmente fechada, os alunos fazem fila e aguardam a chegada do professor. Esta sala permanece fechada por guardar um microcomputador. Os professores entram nas salas, cumprimentam os alunos, guardam suas bolsas, organizam o material a ser utilizado no momento, escrevem o cabeçalho no quadro seguido de alguma atividade para os alunos a ser copiada do quadro, e retornam ao refeitório para tomar café. Somente dois professores faziam orações no início da aula, a professora Sônia, no horário matutino e a professora Diva, no horário vespertino. Orações e músicas religiosas foram lentamente sendo incorporadas ao espaço escolar a partir do segundo semestre letivo, e nos últimos eventos as apresentações de duas professoras envolviam canções e coreografias evangélicas.

$\mathrm{O}$ café dura em torno de quinze minutos, às vezes um pouco mais. Costuma ter pão, leite, café, ovos e margarina. Alguns, de vez em quando, trazem algo diferente, tipo pupunha, açaí, bacaba, etc. Todos tomam café juntos, à exceção da auxiliar de serviços e da merendeira. Estas, às vezes, sentam-se em outra mesa. O professor Edmar não toma café, mas algumas vezes saía da sala para conversar com os colegas.

O momento do café foi um momento significativo na integração da equipe e no contato com a pesquisadora. Os agentes conversam sobre vários assuntos, desde comidas e rotinas familiares, questões escolares e profissionais, até políticas internacionais.

Durante o segundo semestre letivo, a diretora autorizou o café da manhã para os alunos, quando era servida uma caneca de leite. Esta era servida logo após o café dos professores, aproximadamente às oito horas.

Terminado o café, todos voltam para suas salas, e continuam a atividade do dia. A escola era silenciosa. Risos e conversas eram ouvidos apenas quando se chegava bem perto, à parede, ou à tarde, com as atividades da turma do $2^{\circ}$ período. Os ruídos aumentaram com a chegada de uma professora recém-concursada, no segundo semestre letivo.

As salas ficavam com as portas semiabertas. Era possível ouvir do refeitório as falas dos professores e pouca movimentação nas salas. Após algum tempo, a porta da sala de aula 01 passou a permanecer fechada. A argumentação da pesquisadora sugere que isto ocorreu após os desentendimentos que o professor teve com a direção da escola, principalmente no que tange à metodologia, mas também porque o ruído das salas muitas vezes atrapalhava as aulas da sala improvisada no refeitório e vice-versa. Os alunos tinham liberdade para sair e beber água ou ir ao banheiro, com o cuidado de sair no máximo dois por vez, a fim de evitar tumultos no refeitório ou nos banheiros. 
Em sala de aula, sentado à cadeira, o professor passava o conteúdo no quadro, aguardava um tempo por ele considerado suficiente para que a maioria dos alunos pudesse copiar. Então, explicava o conteúdo, lentamente, com voz alta, e perguntando frequentemente se todos haviam entendido. Após explicações, passava exercícios no quadro. A correção costumava ser feita após o intervalo da merenda. Neste momento, os alunos se ofereciam para ir ao quadro e alguma euforia acontecia mesclada com xingamentos, ocasião em que um aluno acusava o outro de não saber escrever ou não saber fazer o exercício. O professor indicava quem deveria se levantar e ir ao quadro. De vez em quando, atendia aos pedidos dos alunos, outras vezes convocava os que não se ofereciam. Alguns, quando chamados pelo professor, recusavam-se a ir ao quadro. Em certos casos, o professor insistia, em outros ia até o aluno para confirmar que este não havia sequer copiado o exercício do quadro. Nestas situações, o aluno era repreendido ou, pelo menos, questionado. Apesar de sua voz forte, e do estabelecimento da disciplina através do tradicional "cala a boca!", este professor não era considerado como o que humilhava ou ofendia os alunos, mas o que ensinava e estimulava a participação. Sua postura lhe conferia prestígio junto aos pais e também aos alunos.

Momentos de descontração. Os alunos divertiam-se com o fato de o professor escrever ao quadro sentado em sua cadeira, de costas para a turma, entusiasmavam-se com a possibilidade de ir ao quadro, ou de ajudar o professor.

$\mathrm{Na}$ sala improvisada no refeitório, a dificuldade de manter a concentração dos alunos era uma tônica cotidianamente presente. Os alunos mudavam constantemente de posição na carteira ou mesmo de lugar. A turma de primeira série era considerada como uma turma com muitos alunos especiais, a maioria há dois ou três anos cursando a mesma série. Mas foram considerados alunos-piloto, segundo relato indignado de uma professora. Regras para mudança do comportamento eram sempre verbalizadas pelo professor, assim como pela merendeira e pela agente operacional. No ambiente de sala de aula eram frequentemente lembrados que "ali não se deve correr, ali se deve prestar atenção, ali... há regras e regulamentos, direitos e deveres". Há o direito de estudar, mas o dever de se comportar, de cumprir as atividades estabelecidas.

A principal atividade era a cópia. Até mesmo quando professores entregavam um pequeno texto mimeografado para ser colado no caderno, este devia ser copiado na folha seguinte. Exercícios repetitivos, como escrever os números de um a duzentos; copiar o alfabeto, o nome completo, palavras e frases até o final da folha. Músicas eram utilizadas na dinâmica de apresentação, que é fase inicial dos subprojetos, e também nas apresentações que alunos faziam nos eventos culminância. Exceção para as aulas do segundo período, que fazia 
uso diário deste recurso. Observou-se que algumas atividades menos rotinizadas foram propostas principalmente por uma professora do turno vespertino e com a turma do segundo período de Educação Infantil.

Dinâmicas diferenciadas estavam previstas nos subprojetos de alfabetização, estabelecidos no início do ano letivo pela diretora e a equipe de professores. Entretanto, com a chegada de novos docentes, estas atividades foram subsumidas. A direção da escola demonstrava incentivar e esperar dos professores criatividade, e o uso das técnicas propostas no Projeto da escola, colocando-se à disposição para partilhar idéias e apoiar no que fosse possível. Não se observaram situações em que jogos fossem utilizados em sala de aula, a não ser em momentos pontuais, como atividade de lazer.

A manutenção e controle da disciplina era responsabilidade de cada professor, e para isto repreensões eram freqüentes, além de alguns castigos, como ficar em pé, de cara para a parede ou não sair para merendar junto com os colegas. A merendeira e a agente operacional também compunham o cenário explícito da vigilância e controle, na tentativa de silenciar os corpos. Uma classe disciplinada é uma classe silenciosa, ainda que para isso valha a punição.

Dois professores indicavam ter maiores dificuldades com uma das turmas que possuíam, nas quais havia alunos por eles considerados com necessidades especiais, ambas no turno matutino. Dentre os problemas que mencionaram, um aluno possuía estilhaços de bala na cabeça, outro era epilético, outro aluno com diagnóstico de atraso cognitivo, outros que permaneciam apáticos em sala, e outros alunos que, na consideração dos professores, deveriam ser encaminhados a uma junta avaliativa. Os alunos apresentavam comportamentos dispersos e agressivos, sendo necessário chamar atenção, em vários momentos, tomando parte do tempo de aula com este procedimento. Constatou-se que, em uma das turmas, esse problema emergiu após troca de professor no mês de agosto, quando a mesma passou a ser regida pela professora iniciante, e mesmo assim, após um tempo, era mais facilmente contornado. Com a professora anterior, a turma era considerada sob controle. Em relação à outra turma, além de concentrar os alunos repetentes e de ocupar um espaço improvisado no refeitório, passou por quatro professores durante o primeiro semestre letivo.

Mas há o bom castigo: ser mandado para a diretoria, onde a diretora sempre recebia o aluno e costumava começar a conversa perguntando carinhosamente: "o que foi que aconteceu, meu filho?" "Então fique um pouquinho aí para descansar". "Você quer uma folha de papel para desenhar?". 
Diante de medidas de controle e de um tempo demasiadamente longo para permanecer sentados, os alunos inventam estratégias para circular, seja para pedir borracha emprestada, ir ao banheiro, beber água, numa explícita manifestação do desejo de circular e arejar.

Brigas e agressões verbais entre os alunos eram frequentes, assim como a denúncia do mau comportamento do colega. Apesar das brigas, estavam sempre unidos.

Os alunos, se por um lado apresentavam certa resistência em atender às exigências dos professores, principalmente as exigências posturais, por outro lado, demonstravam-se empolgados por ter acesso ao conhecimento sistematizado, e satisfeitos quando aprendiam. Em muitos momentos observaram-se alunos afetos à tarefa, procurando colaborar com os professores, inclusive oferecendo-se para auxiliar o professor e os colegas. Este auxílio consistia em tentar explicar o que havia aprendido ou mesmo em copiar e resolver a tarefa para o colega, primo ou irmão.

Às nove horas era servida a merenda, com duração em torno de quinze minutos, e cujo cardápio variava de pão com margarina, bolachas, macarrão, arroz doce, mingaus, alguma fruta, geralmente maçã ou banana.

Quando chega o horário, a merendeira ou a auxiliar matutino vai até as salas de aula e avisa que a merenda será servida. Os professores liberam os alunos, que se dirigem ao balcão, pegam a merenda e sentam-se às mesas, em pequenos grupos. Ao término, colocam o prato e/ou caneca no balde, e retornam para a sala. Alguns alunos deixavam o prato nas mesas. Observou-se no turno matutino que um aluno, considerado aluno especial, sai da sala para receber a merenda e rapidamente retorna para merendar na sala, não se relacionando com os demais.

O intervalo da merenda era curto, havia pouco tempo para alguma brincadeira. Os professores permaneciam no refeitório, circulando rapidamente entre a secretaria, o toalete e as salas de aula. A maioria dos alunos permanecia sentada aos bancos, à exceção de uns poucos meninos e meninas. Também não há espaço para que as crianças se dispersem. Quando isto ocorria, ou quando o zum-zum-zum ficava alto demais, um professor chamava atenção dos alunos, e todos eram conduzidos para as salas de aula. Ainda assim, o burburinho era grande, os alunos conversavam, riam, brincavam, e também se agitavam, principalmente nos dias mais quentes.

A merenda era oferecida exclusivamente pela escola. Não havia venda de doces, biscoitos ou salgadinhos, e poucos eram os alunos que levavam algum alimento ou guloseima de casa. $\mathrm{O}$ professor das turmas de terceira série mantinha seus alunos rigidamente sob seu olhar e vigilância, permanecendo no refeitório durante a merenda, e pouco se ausentando para 
ir à sala ou ao banheiro. Mais uma vez a vigilância, que marca os corpos e estabelece nas relações de poder o lugar instituído de quem fala e de quem obedece.

Não se observaram orientações no sentido de lavar as mãos e escovar os dentes após as refeições, nem espaço/tempo dedicado a esta tarefa.

Ao final da merenda todos voltam para as salas, para o segundo momento de atividade, até as dez e vinte e cinco, quando começam a se preparar para a saída. Este segundo tempo era geralmente, utilizado para complementar a atividade do dia com exercícios, e raramente para introduzir algum assunto novo. Também nos dias que antecediam a realização de algum evento, destinavam o horário para os ensaios.

Fora das salas, a rotina também se inscreve. Ao serviço da cozinha, a cozinheira acompanha tudo o que se passa ao redor. Está atenta às salas, às vozes, aos que circulam, às pessoas que se aproximam pelo lado de fora. A limpeza do espaço é feita pela servente, que prepara o ambiente para o segundo turno. O refeitório é circulação, por onde se movem agendas, encontros, e planejamentos: a agente operacional preenchendo formulários ou organizando arquivos, professores que preparam folhas mimeografadas, o motorista à espera do horário, o professor que ministra aulas, a recepção de visitas, canários que taramelam no alto, limpando as teias de aranha.

A diretora geralmente está em sua sala. Começa sua rotina junto com os professores, mas muitas vezes precisou ausentar-se para reuniões ou outros compromissos. Em suas ausências, a agente operacional ou a professora de apoio fica com a chave da diretoria e responsável pela escola. De modo geral, a diretora estava na escola, e dividia o tempo entre as exigências burocráticas, pesquisa e preparo de material para apoio pedagógico, e atendimento aos pais e moradores. Observamos que a diretora dedicava especial atenção ao atendimento aos pais, interrompendo qualquer atividade quando chegava alguém.

Após a criação do Conselho Escolar, a preocupação voltou-se para o repasse de verbas. Com isto, a direção da escola envolveu-se em novas atribuições, no sentido de elaborar os documentos necessários para este repasse e em proceder à cotação, compra e prestação de contas dos recursos recebidos. O tempo era curto, pois os recursos foram disponibilizados em outubro e deveriam ser executados até início de dezembro.

Na saída, os alunos que moram na comunidade onde se localiza a escola saem e vão a pé para suas casas. Os que moram em outras localidades aguardam o motorista, que leva o grupo, trazendo os alunos do horário intermediário. Neste percurso, um professor sempre acompanha a viagem. Há uma tabela, indicando quem acompanha as viagens em cada dia da semana. 
O trajeto escola/casa/escola oferece oportunidades interessantes. Observou-se que os alunos, em ritmo acelerado, seguem para o ônibus. Às vezes aguardavam enfileirados no corredor, livres do controle sobre suas condutas. Risos, algazarras, empurrões... Assim flui a dinâmica da vida. No ônibus, não é permitido abrir as janelas, e o motorista está atento, solicitando do professor acompanhante as providências. O professor acompanhante, durante o percurso, permanecia sentado próximo ao motorista, referindo-se aos alunos apenas para chamar atenção.

Ao acompanhar algumas viagens, a pesquisadora instigava: como aproveitar este momento pedagógico?

O horário intermediário começa oficialmente às dez e trinta. Entretanto, este é o horário em que o ônibus está saindo da escola para levar os alunos do turno matutino para casa e recolher os do segundo turno. Assim sendo, chega à escola em torno de dez e cinquenta ou dez e cinquenta e cinco. Os professores já estão nas salas, e os alunos às vezes são recebidos no refeitório, outras, entram diretamente nas salas. Não há filas para entrar ou sair. São duas turmas neste turno, a turma de $1^{\circ}$ ano (ciclo) e uma turma de $3^{\mathrm{a}}$ série, e os professores são os mesmos que ministravam aulas nas salas de aula, no horário anterior. $\mathrm{O}$ professor que ocupava o refeitório retornará à sala de aula no horário vespertino. Neste intervalo, aproveita para organizar seu material, planejar atividades, ler, oferecer dicas culinárias à merendeira. Também durante o intervalo costumavam chegar as professoras que ministravam aulas somente no turno vespertino. Uma delas está na escola desde sua inauguração, substitui a diretora em suas ausências e, com a chegada de novos professores, passou a exercer a função de professora de apoio. Retornou à sala de aula em outubro, após a saída de uma professora.

As duas turmas do turno intermediário aparentavam ser mais silenciosas. Quando se passava perto da escola parecia lá não haver ninguém. O tempo era curto. Ao sinal da merendeira - aproximadamente ao meio dia -, de que o almoço está pronto, os professores deixavam os alunos nas salas fazendo alguma atividade e dirigiam-se ao refeitório para almoçar.

O almoço era rápido, em torno de 20 minutos, sem intervalo para descanso. Após o almoço dos professores, servia-se a merenda dos alunos, que durava em torno de quinze minutos. Observaram-se neste turno algumas alunas que sentavam sempre juntas e andavam de mãos dadas, parecendo não se relacionar com os demais. Costumavam trazer o lanche de casa, e aparentavam melhores cuidados pessoais e de higiene. Ao término da merenda, todos retornam às salas para o desfecho do dia. Este horário é visivelmente o mais comprometido. 
Aproximadamente às treze horas e vinte minutos, os alunos começam a se preparar para a saída, que geralmente ocorre em torno das treze e vinte e cinco. Da mesma forma que no horário matutino, os alunos que residem na comunidade vêm a pé e retornam do mesmo modo, para as suas casas, sozinhos, ou com os irmãos. São poucos os que são conduzidos pelos pais, pois a comunidade é pequena, muitos são parentes e vêm em grupos de irmãos e primos, todos se conhecem. Além disso, muitos pais estão trabalhando, e os filhos ou ficam em casa sozinhos, ou com algum parente, tio, tia, avó, ou ainda sob a vigilância de um vizinho.

O ônibus fazia o mesmo percurso, levando e trazendo alunos. O terceiro turno, vespertino, inicia-se aproximadamente às treze horas e cinquenta minutos, terminando impreterivelmente às dezesseis e trinta. Neste turno estão os alunos do segundo período. Esta turma chamava atenção pela vivacidade, pela exigência de atividade e pela adesão às propostas do professor. Conforme relato do professor, foi sua primeira experiência com Educação Infantil e sentiu-se muito motivado em trabalhar com a turma. Tanto que desenvolveu com eles o que considera ser atividades de uma escola particular, chegando a adquirir uma máquina copiadora, vários livros infantis e jogos pedagógicos.

\footnotetext{
"Eu começava com a oração, o canto, a brincadeira e quando eu dizia agora vamos fazer a primeira atividade, eles "êêêêe!”. Eles gritavam, sabe? Aí, diziam 'professor, professor! Fazer tarefa'. Eles faziam logo pra terminar depressa, 'professor me dê mais um!' ou então, 'professor,. quero outro." Eles chamando, pediam, ai você passava outro ... e papapá, faziam! E aí, quando terminava o bimestre, eles levavam um monte de atividade, você via a evolução, porque você passava vários trabalhinhos de coordenação motora, vários trabalhinhos de iniciação, português, matemática, de cien, do que fosse, e..., só sei que eu gostei muito de trabalhar com os pequeninos. E sentia a dificuldade deles" (prof. Jacó).
}

Professor e alunos construíram um processo de grande envolvimento e motivação. Impressionava a atitude de persistência que muitos alunos demonstravam na realização da tarefa, algumas vezes cantando em uníssono alguma música, como um canto de trabalho. A agitação presente não era considerada um aspecto negativo.

No refeitório, atividades desenvolvidas pela professora que permaneceu na escola entre abril e setembro, e que ministrava aulas no refeitório eram diferenciadas. A começar pelas carteiras, que eram organizadas em círculo, diferente de todos os outros professores. Os alunos eram estimulados a participar das aulas, emitindo opiniões sobre os temas apresentados e ouvindo os colegas. Uma agenda era utilizada para comunicação com os pais, que também deviam enviar recados ou solicitações à professora. Uma das atividades propostas, sob sua 
supervisão, foi a construção de um questionário para a Festa do Dia da Avó. Os alunos reuniram-se em subgrupos para elaborar uma ou mais perguntas que gostariam de fazer às avós. Posteriormente, a turma compôs o questionário, com treze perguntas, elegendo também os alunos que participariam da enquete. Outra atividade consistiu em planejar uma pesquisa de campo sobre os problemas da comunidade, mas com a saída da professora da escola, a atividade não foi concluída.

No horário vespertino, a merenda era servida às quinze horas. Como nos turnos anteriores, este espaço se constitui em momentos de maior descontração. Nestes momentos, a pesquisadora era mais abordada pelos alunos. Oportunidades para conhecê-los e trocar curiosidades, como por exemplo, "o que faz uma pesquisadora na escola", e "o que vocês acham que faz uma pesquisadora na escola". Destes encontros emergiu outro questionamento interessante acerca dos produtos da floresta, do conhecimento que os alunos possuíam a esse respeito e se este conhecimento era apropriado pela escola.

A culminância era um momento importante dentro do planejamento da escola. Nele, cada professor devia apresentar, de modo criativo, o resultado do trabalho desenvolvido durante o mês. A comunidade era convidada a participar, numa tentativa de aproximação da escola.

Dois eventos eram considerados os mais importantes: o Dia da Avó e a Semana da Família. Conforme relato da diretora, as avós estão presentes na vida de muitos alunos da escola, e cumprem um papel importante na educação dos netos e no sustento da família, uma presença cada vez menos lembrada e valorizada. O Dia da Família é dedicado ao encerramento do Projeto Temático, sintetizando o resultado do trabalho realizado durante todo o ano que, em 2008, teve como meta a integração escola-comunidade.

Houve impasses no mês de junho, entre professores e direção, pois diante da exigência de se fazer tantos eventos, os professores alegaram não dar conta, necessitar de mais tempo para ensaiar, e tentaram limitar a quantidade. Isto não foi aceito pela direção, que exigiu a realização dos eventos previstos, recorrendo ao fato de que, se nos anos anteriores deu tempo, por que este ano seria diferente. E que não seria possível adiar comemorações, isto atrapalharia todo o calendário. No embate, prevaleceu a agenda da direção, com apresentações isoladas e descontextualizadas.

Os dias de chuva ocasionavam transtornos. Goteiras nas salas de aula e no refeitório produziam a "melodia do gota a gota". Chuvas de vento invadiam a sala improvisada no refeitório, e o trajeto até a escola ficava inviabilizado. 
Como parte das promessas eleitorais, tratores aplainaram as ruas da comunidade, para o asfaltamento. Por dois dias, a comunidade esteve limitada na utilização de água, pois, como não há rede de esgoto, a água servida escorre pelas ruas e isto atrapalharia o trabalho. Choveu. As águas e a passagem de carros e caminhões tornaram as ruas inviáveis. O ônibus escolar ficou preso no atoleiro, e professores e alunos tiveram que sair da escola " $a$ pé, descalços $e$ atolados".

Para a direção da escola, o asfalto não é interessante, argumentando que com o mínimo do que o poder público denomina "urbanização", a escola deixará de ser rural e perderá o transporte escolar. Para a comunidade, o asfalto é parte de suas reivindicações pela melhoria do local e das condições de vida. Embutido na argumentação da diretora pode estar o fato de que, sendo escola urbana, ela e os professores cujos contratos foram firmados para trabalhar em área rural devem sair da escola.

A presença dos pais na escola foi pouco solicitada. As reuniões não ocorreram conforme previsto, e os pais, quando chamados, esperavam a notícia de que algo não estava bem, agendando a surra. Desconstruir concepções e pais desconfiados. Foi interessante observar um pai que, chegando à escola bastante apreensivo, foi comunicado que seu filho foi indicado, como melhor aluno da escola, para receber o prêmio "Plugado no Saber", e ganhara um microcomputador. Bom quando a escola pode falar do que seu filho pode, do que ele sabe fazer, e não do que lhe falta.

\section{Na escola, entre práticas e tensões.}

Mesmo já tendo feito referências a situações internas à escola, no tópico anterior, considera-se relevante apresentar elementos das práticas, relações e situações que ocorrem efetivamente no dia a dia da escola, práticas que se produzem e se reproduzem no cotidiano escolar, e que trazem questões relevantes ao estudo proposto por esta pesquisadora.

Ao destacar as práticas pedagógicas quer-se enfatizar que, concordando com Heckert e Barros (2007), entendemos por prática um corpo de discurso e procedimentos, de caráter heterogêneo e circunstancial, que constrói sujeitos e objetos, e produz verdades. No cotidiano escolar encontram-se práticas diferenciadas, sócio-historicamente engendradas e atravessadas por diferentes forças em luta, seja por permanecer, reforçando relações hegemônicas, outras por se instituir. 
Nessa heterogeneidade de práticas, destacam-se as que, de algum modo, se fizeram intensas nos momentos em que a pesquisadora circulou pelo cotidiano, as que a movimentaram, a afetaram e, ao mesmo tempo, se deixaram afetar. As que também dizem respeito à pesquisadora, quando nelas se vê, pois fala do que está em si mesma (MACHADO, A., 2005).

\subsection{As práticas do bom saber}

A proposta pedagógica estabelecida no Projeto Temático 2008 privilegia a construção coletiva do conhecimento e a participação da vida em comunidade e da comunidade. Tomando por base a pedagogia de projetos e o sociointeracionismo, propõe a organização de conteúdos e atividades curriculares através de projetos voltados para as questões cotidianas da comunidade. Uma escola inserida na realidade, aberta a múltiplas relações sociais.

Conforme informado pela diretora, o trabalho com projetos possibilita um grande envolvimento na prática cotidiana, assim como o envolvimento do aluno em sua formação. Sugere que a aprendizagem deve começar pelos acontecimentos em que os alunos estão envolvidos e cujos significados procuram construir, numa perspectiva interdisciplinar. Assim, o ambiente escolar deve ser um lugar em que o aluno possa atuar, discutir, realizar e avaliar, de forma prazerosa e significativa. O professor deve estimular os avanços dos alunos, e o erro é considerado parte do processo.

Entretanto, caminhando ao lado dos registros formais, as ações cotidianas não parecem se fundamentar nesta perspectiva. Os exercícios escolares são em sua maioria construídos na exigência de esforços individuais. As aulas são expositivas, fator limitante que reduz as possibilidades de participação dos alunos. Cabe destacar que, mesmo expositivas, algumas aulas eram mais participativas. A ênfase na alfabetização está presente em todas as séries, isto é, cobra-se dos alunos que devem saber ler e escrever.

As atividades em sala de aula pouco estimulavam a produção, a criação, tornando-se rotinizantes, dispersas, com tendência à homogeneização e a reprodução. Não se observaram atividades grupais, ou atividades que promovessem a descoberta, a interação, à exceção de algumas atividades propostas por um professor para uma turma de Educação Infantil que, entretanto, não utilizava os mesmos recursos com a turma de primeira série, para quem também lecionava, e pela professora que permaneceu na escola por quatro meses. Em conversas informais, esta professora relatou que trabalha desde o início com a autoavaliação. 
Observou-se que a escola, como lugar de aprender a ler e escrever estabelece a prática do bom saber, e este bom saber é o que a escola ensina. Privilegia a transmissão do saber universal, dentro dos conteúdos estabelecidos no Programa Oficial de Educação Básica do município que, conforme relato dos professores, é comum a escolas urbanas e rurais.

"Não tem diferença não. Aliás, a diferença é que, porque tem outro Programa que fizeram agora por causa do ciclo (para as escolas urbanas). (...) Diferente em termos, porque ele só divide os conteúdos. Agora lá não, a proposta de lá ela é inteira, ela vem no projeto com tudo dentro, mas é a mesma proposta, é o mesmo conteúdo, a mesma avaliação, aquela redação é a mesma, o da metodologia, então quer dizer que não tem quase diferença (...) ainda mais de conteúdo, é o mesmo, a parte de conteúdo não mudou" (Profa. Diva).

Os conteúdos são organizados de acordo com a suposta capacidade de aprender dos alunos, de modo linear e crescente em nível de complexidade. Apenas uma professora comentou que este Programa é uma referência, não uma obrigação, ressaltando também a necessidade de enfocar aspectos da cultura local.

\begin{abstract}
"Ele dá um norte, pra você trabalhar, (...) é um programa, eu pelo menos, acato como sugestões o conteúdo que tem lá, e incluo outros que acho necessário. (...) porque ele não é regionalizado, dá muita prioridade a um conteúdo mais geral e a gente elabora nosso plano, nós temos que começar a trabalhar a nossa cultura, primeiro. (...) Ele te dá um leque de conteúdos, e que também você não é obrigado, em janeiro trabalhar aquilo, em fevereiro trabalhar aquilo, entendeu? Você vê a receptividade da turma, você vai saber quando fazer aquilo ali; vem como sugestão para o professor. Ele não é uma coisa, ou pelo menos eu nunca vi como sendo uma coisa obrigatória. $O$ que faz a coisa ser obrigatória nas escolas é a própria administração que impõe. E o professor vê se faz. É uma briga que eu to tendo agora ai" (Profa. Alva)
\end{abstract}

A atenção continuada é considerada um elemento necessário ao aprendizado e esta exigência circula nos espaços da escola.

"Outra coisa, como eu tava te falando, não dá pra desenvolver um bom trabalho, eu pelo menos sou assim, se os alunos não estiverem todos sentados, concentrados, prestando atenção no que eu estou falando. Primeiro eu explico [...] Nessa hora eu não admito aluno conversando. Tem que prestar atenção" (Profa. Sônia).

O ensino participativo, o mencionado contato direto do aluno com a realidade e o estímulo à solução de problemas, assim como a relação com o cotidiano da comunidade não foram observados durante o período em que esta pesquisadora esteve na escola, salvo 
experiências pontuais. Citando uma experiência ilustrativa, alunos da segunda série elaboraram um roteiro de entrevista para a comemoração do Dia da Avó. A atividade consistiu em entrevistar avós presentes no dia da festa, e a atividade proporcionou bastante interesse e alegria. Significativa presença de algumas avós que contaram um pouco de suas histórias, sentindo-se emocionadas por falar, na escola, de coisas que nunca haviam conversado com seus netos. Conforme relatou a professora, os alunos produziram as questões e se empenharam na atividade.

"Até mesmo os que não sabem escrever direito, queriam colocar suas perguntas. Pediam para que outro colega escrevesse, eu os deixei à vontade, foram eles mesmos que organizaram as perguntas, o roteiro, e quem faz o quê. Olha, foi muito bom. Uma atividade em que a gente tira tudo..." (Profa. Ana).

Em outra experiência interessante, observou-se a participação da merendeira na organização de uma atividade junto a um grupo de alunos, para ser apresentada na comemoração do Dia da Família. A atividade, que consistiu em uma coreografia evangélica, envolveu o conjunto merendeira e alunos de diferentes turmas e idades, em todas as etapas: a escolha da música, os passos da coreografia, cada um trazendo sua contribuição.

Pouco se fala dos saberes tradicionais, e quando isto ocorre, são tratados numa dimensão folclórica: a festa do boi, as comidas típicas, o artesanato. A questão ambiental parece estar associada aos problemas urbanos, e mesmo com um entorno de possibilidades, não se enfatizam os saberes seculares que possibilitaram o envolvimento ser humanoambiente. Também não há direcionamento para as questões rurais e muitos conhecimentos transmitidos estão desconectados da realidade vivenciada pelos alunos.

\subsection{A produção das dificuldades}

Um aspecto relacionado ao que os professores entendem como componente necessário ao desenvolvimento do aluno, e parte de seu trabalho pedagógico, envolve atentar para as dificuldades escolares, mencionadas por todos os agentes institucionais. Como pauta ordinária nos cotidianos escolares, as dificuldades de aprendizagem estão presentes e geralmente relacionadas às condições intrínsecas ao aluno, sua família ou a vida rural. De alguns alunos, pouco se espera; mas, para os professores, também interessa poder compreender o porquê das dificuldades. 
"Eu me senti muito prejudicado neste espaço aqui, isso aqui é muito aberto, onde tudo tirava atenção dos meninos, e eu tava com uma turma que (...) eu percebi assim, todos tinham, do pequeno ao grau maior, uma questão de, comprometimento, sabe?" (Prof. Jacó).

"É. As crianças têm muita dificuldade, eu acho muita dificuldade no aprendizado. Eu não sei se é falta de interesse, eu não sei se é problema familiar. Eu sei que... a gente, às vezes, repete... Eu, eu, conversando com o pessoal do distrito, no mês passado, quando eles vieram aqui, aquela equipe, (a equipe pedagógica da SME sugeriu mudar a metodologia). Aí então vamos mudar a metodologia. Agora eu te pergunto: a minha metodologia é uma, a sua é outra, a de cada professor é de uma. E quando a turma! Não é um, nem dois, nem três, a turma num todo! Tira-se três, quatro que houve rendimento, e o resto... Já passou por várias metodologias. E aí? (...) Então quatro professores não acertam a metodologia?” (Profa. Lúcia)

As dificuldades de aprendizagem são explicadas em função das condições específicas da população rural e dos problemas familiares. Destes, destacam a falta de acompanhamento por parte dos pais, em geral atribuída à baixa escolarização ou ausência dela. Os professores também fazem referência à falta de assistência, sugerindo certo abandono e questões morais.

"Você pode perceber, assim, a gente tem uma diferença muito grande entre o aluno que ta na rural, e vai para uma urbana, a gente vê que ele tem essa diferença, eles dois. Eles são diferentes, principalmente no desenvolvimento, no psicológico dele, é diferente, o investimento dele é diferente, a aprendizagem dele é mais lenta. É mais lenta que o pessoal da urbana, porque os meninos da urbana eles são mais desenvolvidos, são mais ativos; eles aqui não, são tímidos, eles já são assim mais retraídos. Outros têm dificuldade de ler, porque eles... os pais são analfabetos, às vezes, é muito difícil ter um pai que tenha um estudo melhor (...) E muitas vezes a criança ela fica na lavoura, em vez de estar estudando, ta na roça, chega da escola e vai trabalhar. E se ele estuda de tarde, às vezes ele nem almoça, não come nada e já vai para escola, ou chega do trabalho e vai para a escola, então isso aí puxa, cansa o psicológico da criança, e quando chega na escola já ta cansado. Então, eu acho que é essa a dificuldade da rural, pra criança. Muitas vezes a criança tem que andar, olha, $\mathrm{km}$ e $\mathrm{km}$ para chegar na escola, outras vezes tem que pegar, às vezes pega motor, e anda a estrada dois, três quilometros de estrada. Aí, isso tudo dificulta a aprendizagem" (Profa. Diva).

"Aonde existe a, a falta de uma formação maior dos pais, há dificuldade maior de acompanhamento. Pais analfabetos não tem muitas vezes nem como ver ou saber o que o aluno ta fazendo. Então o rendimento lógico que é menor. Se você trouxer os alunos da rural para fazer alguma atividade competitiva com quem é da urbana, normalmente perdem. Raros são os casos quando um aluno ou outro tem a capacidade, habilidade mental, se destaca mais ele ganha, alguma coisa, e tal” (Profa. Lúcia).

"Olha, eu já tive em três localidades rurais de trabalho. A que achei maior dificuldade de trabalho, com a questão de aprendizagem foi essa (...) Porque a assistência dos pais é muito pouca. Chama-se pais, chama-se pais, não 
vem, quando vem, sempre tem uma desculpa porque trabalha, trabalha, não tem como, eu não posso, eu deixo com não sei quem, quando penso não tá, e quem padece é a criança. Então, fracos, fracos, fracos. (...) Tem muitas casas, pelo menos cinco, a criança sozinha dentro de casa. Muitas vezes, teve aqui, disse a mãe aqui numa reunião, ai meu deus do céu tenho que ir porque deixei meus três filhos sozinhos dentro de casa. E agora você sabe, tudo o que acontece na casa, desses meninos sozinhos. Tudo que acontece" (Prof. Jacó).

"Eu tive no ano passado, uma aluna que, a outra colega era tia, tendo assim, mesma idade e tamanho, né. Embananou a minha cabeça" (Profa. Sônia).

"Então essas crianças acabam tendo problemas em casa, muitos casos, eu digo que a maioria tem, e isso reflete na escola” (Profa. Lúcia).

Observaram-se as baixas expectativas dos professores a respeito dos alunos, em virtude do local onde moram e das características da população rural, que diferem bastante do padrão ideal de aluno. As famílias também são estigmatizadas. Essas expectativas não só norteavam as práticas dos professores, mas também eram introjetadas pelas crianças, especialmente por aquelas que apresentavam maiores dificuldades de aprendizagem.

Referem-se a comportamentos inadequados em função da falta de educação.

"Eu vou construir uma praça num bairro popular onde eles não sabem cuidar de uma praça? Destroem tudo! Né? O que aconteceu uma vez aí que, é..., tiraram o pessoal da favela, construíram um conjunto habitacional novo, passaram eles para esse conjunto, em poucos meses não existia mais pia, não existia vaso sanitário, não existia torneira, não existia, detonaram! Porque não tem educação. Não é? Pra isso, tem-se que desde pequeno, já começar" (Prof. Jacó).

Isso justifica que a escola deva promover a aquisição de comportamentos relativos ao convívio social e de informações que são consideradas necessárias à educação da criança rural.

"Temos que dar os beneficios, o que é bom de um, tipo..., um grupo de pessoas, como se diz, já desenvolvido, né, que passou por uma evolução, que eles não passaram (...) então você vem ensinando, no convívio, saber como se portar na cidade, cuidar de uma praça..." (Prof. Jacó).

Lidar com as dificuldades de aprendizagem envolveria uma disponibilidade por parte do professor para se dedicar aos alunos; mas, também, a possibilidade de separá-los por níveis, a fim de poder fazer um trabalho intensivo com os que apresentam maiores 
dificuldades, pois, em sala com diferentes níveis, um aluno atrapalha o outro. Envolve também preparar o professor.

\begin{abstract}
"Agora, se você tivesse esses alunos, é..., como ele, com um número menor, onde você não tivesse responsabilidade de tá ensinando, com níveis diferentes; se fossem separados em níveis, você tem todo como fazer um trabalho com eles, tudo no mesmo nível. O problema é esse: você tem que ter a resposta daqueles alunos, a resposta daquele outro grupo, a resposta desses, quando esses atrapalham que tenha o desenvolvimento desses, desses e desses. E ainda mais, tem a questão da preparação do professor que está trabalhando, a questão da inclusão o problema é esse. Sim! Falam da inclusão papápá, nas salas normais... Prepararam os professores? Deram cursos? Como trabalhar com os vários níveis de, como detectar, como trabalhar, não sei o quê?" (Prof. Jacó).
\end{abstract}

\title{
3.3. A manutenção da disciplina
}

A manutenção da disciplina é considerada pelos professores como algo necessário à aprendizagem e à organização do trabalho, e procuram mantê-la com rigidez. Durante o período de coleta de dados, constataram-se vários momentos em que esta foi requerida. A disciplina promove organização, obediência e cumprimento das tarefas propostas. E cabe ao professor o "manejo de classe e controle da disciplina".

"No momento que a professora coloca os pés na sala, a primeira coisa que ela tem que observar é como que tá a harmonia dos teus alunos" (Profa. Sônia).

A disciplina também envolve o controle e a circulação no espaçotempo. O cotidiano escolar é regido por tempos estritos para os acontecimentos. Os alunos são estimulados a fazer funcionar o corpo conforme este tempo determinado por outros: a hora de estudar, de ir ao banheiro, de merendar.

\footnotetext{
"Primeiro, eu, eu não sei trabalhar com o aluno em cima de mim. O aluno gritando, falando, não! Procuro concentrá-los todos, é hora de orar, vamos orar. É hora de cantar, é de cantar. E quando eu partir pro conteúdo já tarem relaxado" (Profa. Sônia).
}

O silêncio é estabelecido como condição para o aprendizado ou, em determinados momentos, como castigo. Os professores solicitam continuamente o silêncio, devendo o aluno falar preferencialmente quando solicitado. Mas não há tanta rigidez: pequenas conversas paralelas são aceitas desde que não alterem o ritmo do trabalho. As falas e silêncios também 
são incentivados como parte do processo educativo: é preciso saber falar, saber ouvir o professor, e ouvir o colega. Vale ressaltar que uma sala de aula é atravessada por silêncios, e há momentos em que o silêncio também é utilizado pelos alunos como resposta ao professor.

Os professores indicam que é necessário acompanhar as atividades desenvolvidas pelos alunos, se possível individualmente, incluindo nestas a organização do material escolar. Uma professora comentou:

"Caderno sujo, letra mal feita, tudo isso a gente tem que observar, faz parte da formação do aluno. Questão de exercícios, orais, eu gosto muito; e te digo: pra gente se sentir segura nessa questão de leitura, eu vou de um por um. (...) Depois de trabalhar um conteúdo novo, vou conferir e aproveito para ver como estão fazendo, como estão os cadernos. Então eu coloco no quadro, ai pergunto de um por um, pra você ver de que maneira se avalia" (Profa. Lúcia).

Os professores consideram a necessidade de castigos e punições, principalmente como estratégia de controle. Isto é enfatizado inclusive nas reuniões com os pais, como orientação para que o aluno possa ser mais aplicado aos estudos. Apenas em alguns casos, a orientação objetiva substituir os castigos físicos mais severos por alguma proibição, como não brincar na rua ou deixar de assistir um programa de TV. Em seus depoimentos, informaram que alguns alunos têm dificuldades de permanecer sentados, circulando pelo espaço da sala de aula, conversando, brigando com os colegas, e solicitando sair para beber água ou ir ao banheiro continuamente. Há dificuldade de manter a imobilidade e a concentração após o término da tarefa, e com alguns alunos, há muita dificuldade em manter sua concentração e envolvimento com as tarefas propostas pelo professor. Outro aspecto mencionado é que a agitação de alguns alunos pode influenciar e pôr em descompasso o grupo como um todo.

Os recursos utilizados para este controle passam necessariamente pela advertência verbal, passando dos pedidos de silêncio às interjeições como: “senta!", “cala a boca!”, ou ainda, ameaças de punição.

"Еu mandei você ficar aî? (...)Se tem trabalho para fazer por que estão em pé? (...) por que isto está assim?” (Profa. Sônia).

"É pra copiar. Aquele que passar por aqui e apagar o quadro vai escrever mais dez vezes no caderno" (Profa. Lúcia)

"O próximo que eu pegar vai ficar de cara para a parede" (Prof. Edmar). 
$\mathrm{Na}$ realização das atividades escolares enfatizava-se o comportamento adequado ao aprendizado. Em algumas situações, o discurso dos professores encaminhava para a humilhação.

\begin{abstract}
"Menino! Copia do quadro, deixe de moleza, você está aqui para estudar e não para brincar. (...) Acabou nada, copia logo isso, deixe de moleza. (...) Olha, eu morria de vergonha! Na primeira série? Deus me livre! Isso se aprende na alfabetização" (Prof. Jacó).

"Como é que pode vir para a escola e nunca trazer o material? Cada dia é uma desculpa, ou não tem lápis, ou não tem caderno, ou não vem (...) Do que adianta vir à escola para não estudar. Assim está estragando a vida" (Prof. Jacó).
\end{abstract}

"Esqueceu nada, ela é uma abestada mesmo, por que não saltou antes?" (Profa. Diva).

As repreensões não aconteciam somente nos momentos mais tumultuosos; eram constantemente utilizadas para garantir a obediência e atenção. E eram públicas. Aos alunos mais "resistentes", práticas mais incisivas. Observaram-se momentos em que um professor, no esforço em tentar conter os alunos sentados às carteiras e em silêncio, utilizou termos mais contundentes. "Eu sei a peça que tu é. Não estuda, não faz nada. Acaba virando o que não
presta".

"Fica aqui! Bora, bora! (segurando o menino pelos braços e colocando-o sentado). Já falei dez vezes pra você! Não sabe obedecer não, menino?”.

Os próprios alunos, com o tempo, também assumem certas práticas de vigilância e controle como parte de seu fazer, denunciando o mau comportamento do colega, sugerindo algum tipo de punição ou mesmo incumbindo-se de punir ou ameaçar o colega, quando se trata de um irmão mais novo ou primo.

Segundo relato de um professor, a indisciplina está relacionada em parte ao estilo de vida dos alunos, que circulam em espaços abertos, sem controle, e por outro lado, à falta de limites por parte dos pais.

"Crianças que não tem limite, então como é que você pode ter autoridade se eles tão acostumados já dentro de casa, a, os pais permissivos, pode fazer tudo, né, e na sala de aula eles querem fazer da mesma forma, e se você não imprime uma autoridade, quer seja pela voz ou, certo, porque se for falar normal não atende" (Prof. Jacó). 
A presença de um adulto junto ao grupo de alunos é percebida como necessária à manutenção do controle, como também ao aprendizado disciplinar. Esta necessidade de insistir e educar pela disciplina é reforçada em vários momentos, tanto pelos professores em sala de aula, como pela merendeira e pelos auxiliares de serviços gerais. Observaram-se situações em que há alteração da dinâmica na ausência do professor, com uma tendência, por parte dos alunos, de abandonar a atividade que estão fazendo e passar a atividades mais agitadas, o que parece soar como uma necessidade de descompressão. O retorno do professor nessas situações é acompanhado de frases como "será que não dá pra deixar vocês sozinhos nem um minuto?" e de sermões objetivando "educar o comportamento". A disciplina ordena o grupo, os corpos e o conhecimento, possibilitando o trabalho pedagógico e o consequente preparo para a vida.

'Se você disser 'fica assim', 'não faça isso, menina', ' eu não já falei pra você...', não adianta, porque eu só via ter alguma..., por exemplo, alguns (alunos) que (outros professores) diziam (que) não faziam nada, quando, quando me vi no negócio eu disse: não saia! Faça! Sente aí! Não sei o quê, o tempo todo cuidando, então, evoluía alguma coisa, ali. Porque tava ali, não tava, pela insistência. Mas só que você acaba não sendo bem visto, se torna anti-social, mas tem hora que precisa né?" (Prof. Jacó).

"Então, eu te digo, esse trabalho, que é pequeno, mas chega, é o que a gente pode fazer também, e é muito lento, muito devagar. Tem que ta todo dia lembrando, avisando, corrigindo, esses meninos não são educados, vivem soltos, essa vida de liberdade, que é diferente da gente que vive na cidade, e não pode mais correr pela rua, veja se você vai deixar seu filho nas ruas hoje em dia. Mas aqui eles podem, eles vivem por ai correndo, vivem soltos" (Profa. Lúcia).

\subsection{A prática do cuidado}

O cuidado foi outra dimensão destacada. Conforme depoimento da diretora e de alguns professores há, na comunidade, situações de violência doméstica e mesmo de violência sexual infantil. Isto motivou os agentes institucionais a promover a valorização da família e sensibilizar para a responsabilidade que os pais devem ter com seus filhos, entendendo que estas situações interferem diretamente no processo de aprendizagem. Os pais são estimulados a cuidar de seus filhos, a acompanhar as atividades escolares e a evitar bater nos filhos. $\mathrm{O}$ discurso da merendeira em reunião de pais é ilustrativo:

"Nossos filhos estão vindo pro colégio, aqui no colégio eles tão bem guardados, porque estão na responsabilidade dos professores da diretora e nossa responsabilidade também, porque eu sou cozinheira, mas eu estou de olho nos filhos de vocês aqui, né (...) E nós, mães, pais, nós temos que estar 
de olho nos nossos filhos, temos que conversar com eles, temos que dialogar com eles porque isso é muito importante. Porque muitas das vezes nossos filhos têm vergonha de conversar conosco, porque nós só chegamos com nossos filhos pra querer bater, pra querer brigar, porque ele fez errado, porque disso, nós também fomos criança, cada um de nós fomos criança, nós sabemos que criança é criança, tem os erro dele. Né! Então nós não temos que chegar com ele e brigar com ele, e querer bater não! Um carinho é muito importante pros nossos filhos" (Merendeira).

A escola coloca-se no lugar do cuidado, pois tendo diversas situações em que os pais trabalham e não tem com quem deixar os filhos, há na escola, a possibilidade de ocupar-lhes o tempo e ocupar-se de seu desenvolvimento. Como mediadora em novas relações, também carrega as expectativas de melhoria de vida para os alunos, e mesmo para a comunidade, colocando-se como parceira nas reivindicações junto aos órgãos governamentais.

\section{A Relação Escola-Comunidade}

Nesta parte, conhecem-se aspectos da relação escola e comunidade, em que se apresentam o que enunciam pais e professores sobre a escola, suas expectativas sobre a escolarização e participação. Buscam-se apreender na trama heterogênea do fazer cotidiano, as diferentes vozes que se manifestam e evidenciam práticas e saberes. Algumas, mais próximas e contundentes, outras, mais distanciadas, essas vozes demarcam as forças instituídas.

Para isto, tomam-se por base os registros das observações realizadas no cotidiano da escola, bem como as enunciações nos vários encontros que ocorreram durante o período de coleta de dados, seja nos momentos mais informais de conversas ou durante as entrevistas.

\subsection{A importância da escola e do conhecimento escolar}

\subsubsection{O que pensam os pais moradores da comunidade sobre a escola}

Os pais foram unânimes em relatar a importância que atribuem à escola e à escolarização. Destacam a importância do conhecimento que ela proporciona.

\footnotetext{
"A escola é boa, promove educação na comunidade" (Carla).

“É importante, né, com certeza, porque ajuda até... a educação vem de casa, né, mas ajuda muito, como eu digo, ajuda os pais. Ocupa, ocupa algumas
} 
horas e, nossa! É tudo muito importante. Ajuda a desenvolver, dá desenvoltura da criança. [...] Falam coisas boas com os alunos. Que tem muitos pais que não conversam certas coisas com os filhos e eles conversam na escola, né, explicam. Vários tipos de coisa, né, sobre a violência, cuidar da saúde, falam das drogas, porque antigamente não tinha essas coisas, mas agora tem, né. A minha mãe não conversava com a gente, e tem muito pai e mãe que não conversa com os filhos. E hoje em dia eles conversam, orientam, teve até encontros, assim, com palestra. A Rita chega em casa contando novidade" (Wilma).

"A escola é muito importante porque dá o ensino e o desenvolvimento pro aluno. Eu me preocupo com o estudo dos meus filhos porque hoje em dia, se quiser ser alguém, precisa estudar. Eu não estudei, não tive essa oportunidade, a gente não tinha escola perto e tinha que ajudar o pai; agora to correndo atrás, mas o que eu posso fazer pros meus filhos não parar de estudar eu faço, porque senão como vai conseguir um bom emprego?" (Erilene).

"Ela educa, né, faz a parte de formação da criança, é um complemento pra família. A família é importante, porque se você não souber educar seu filho não adianta ele ir pra uma escola [...] mas também se não vai pra escola não aprende as coisas que são importante, o conhecimento que ele vai ter que é dado pela escola" (Miguel).

"Na escola ensina muitas coisas, aprende do que é bom e do que não é também; ler e escrever, mas não é só ler e escrever, isso é o principal, é o que a escola tem que ensinar. Agora, ela ajuda na educação geral, os meninos brinca, desenha, todo dia tem uma atividade, coisas que a gente não pode ta fazendo em casa, porque nem sempre a gente tem" (Rosa).

"Eu acho (importante). Porque ela..., aprende as crianças, né. Porque acho isso muito importante, gente que sabe, que dá a resposta certa" (Paulo).

Os pais atribuem um bom conceito à escola pelo ensino ministrado, por ter bons professores e uma diretora muito acolhedora, a quem conferem o reconhecimento por todas as conquistas conseguidas, considerando-a pessoa bastante dedicada ao trabalho e aos alunos. A importância também se relaciona ao fato de trazer melhorias para os alunos e para a comunidade, e de contribuir para diminuir desavenças na comunidade.

"Acho que é bom, tem atividades, o estudo é bom, tem bons professores" (Rosa).

"Ela conseguiu muitas coisas. [...] se não fosse pela diretora, não teria onibus, os professores também, ela não deixa ficar sem” (Carla).

"A escola é um beneficio que teve pra comunidade. Aqui não tinha nada [...] a gente tinha que andar até lá no São Francisco pros meninos estudarem [...]. Aqui tinha muita... confusão. As pessoas, algumas, não queriam a Carla na frente da associação. Então teve problemas com a água, que ela queria tomar, mas não era direito dela. A diretora chegou, e teve uma conversa 
com ela, explicou isso de representação, sei lá, mas que o presidente tem que conversar também com a comunidade. Acho que diminuiu as desavenças, pelo menos no problema da água” (Erilene).

Ainda como característica de uma boa escola, os pais salientam o tratamento que professores e diretora dispensam, sugerindo um diferencial em relação a experiências escolares anteriores.

\footnotetext{
"Acho que é bom, todos atendem bem a comunidade, as pessoas são bem tratadas" (Rosa).

"A gente chega, e é recebido. Quando ela ta, ela vem, fala, conversa, explica as coisas" (Raimunda).

"A diretora é muito boa, ela trata bem, todo mundo que chega lá, ela recebe" (Erilene).
}

Em relação aos professores, consideram que ter bons professores é um requisito para uma boa escola. Ser bom professor envolve o bem querer. O bom professor é aquele que exige, mas também o que é carinhoso com os alunos.

\begin{abstract}
"Se ele trata bem meus filhos, você vai gostar, né" (Raimunda).
"[...] gostava mais da Sonia, ela era muito boa, e dedicada. Não tinha esse negócio de paparicar, não, mas a gente via que ela gostava das crianças e ensinava mesmo" (Rosa).

"Ele ensina, é bom professor. Dá duro nos meninos, não tem essa de ficar fazendo bagunça não, mas se vai pra escola é pra estudar mesmo. Eu não acho bom professor que não passa trabalho, acho que toda mãe deve ver no caderno o que o aluno ta aprendendo [...] a gente vê que ele apóia os meninos" (Eliane).
\end{abstract}

Alguns pais referem-se a problemas com um professor.

"Eu acho que a escola não tá boa não, antes era melhor. Tem um professor aí que só vive gritando com os alunos, daqui a gente escuta. Pra minha filha, ele que não grite não" (Eliane).

"É, ele não tem paciência, fala alto, se irrita. Às vezes grita com os alunos" (Raquel).

Outro problema mencionado relaciona-se às trocas de professores durante o ano.

"O estudo, também, também é bom, os professores passam trabalho, só o que teve, é que mudou uma, né, que acho que é nova, ela é bem novinha, é 
boazinha, mas o Miquéias, ele tava indo bem e deu uma parada. Não sei se sentiu falta da Sônia, [...], porque com a Sônia, ela puxava mesmo por ele. Ele fica meio desatento, às vezes, ela dava atenção, cobrava, quando tinha alguma coisa ela chamava a gente, né, pra vê, pra saber como ele tava em casa, se não fazia o exercício era pra saber por que" (Rosa).

"Não sei não, acho que teve muita troca de professor e isso atrapalhou muito. Num mês mudou duas vezes, ou foi três? Não, é porque voltou de novo pra outra professora. Aí quando a gente viu chegou professor novo, e muda tudo outra vez" (Carla).

A oportunidade de estudar também é ressaltada, considerando que muitos pais não tiveram acesso à escola.

"Eu sempre digo pros meus filhos, olha vocês tem que estudar, tem que se esforçar, porque eu, eu não tive oportunidade” (Raimunda).

"Quando meu pai chegou aqui não tinha nada, ali onde hoje é a escola, dali pra baixo, tinha muita bacaba, a gente entrava na mata para tirar bacaba, tucumã, pesca tinha muita variedade [...] não tinha como ir pra escola, tinha escola, mas era longe, porque esse caminho que tem hoje, antigamente não tinha, precisava dar a volta de barco, só tinha a escola lá do Abdias e da irmã. A mãe não deixava agente ir só porque tinha medo de fera (sucuri, pirarara, piraíba, dentre outros). Eu vim estudar um pouco já depois de grande, junto com meus irmãos" (Rosa).

Alguns pais consideram que a escola precisa de melhorias, tanto em relação à ampliação do espaço físico como na organização do ensino. Sugerem que o aumento da demanda pode ter contribuído para a perda da qualidade.

"Acho pouco o tempo de aula, os alunos não aprendem quase nada" (Graça).

"Devagar, ta muito devagar, as crianças não aprendem porque tem muito pouco tempo de aula. Antes tinha educação física, esse ano meu filho falou, mãe, a gente só fica na sala de aula" (Eliane).

"Essa escola era boa, piorou. [...] Acho que é porque aumentou muito, não sei, mas quando tinha a Mara, a Sônia era muito legal, ela gostava dos alunos, se dedicava" (Carla).

"Ah, tem que aumentar, ou menos mais uns dois ou três quartos, tem dois só, não dá pra todos os alunos, e quando chega na terceira, tem que ir lá pra baixo. Murar também, e a gente vê que, tem que ter uma quadra também, pras crianças, aqui não tem lazer. É três que tem que ter: uma quadra poliesportiva, o muro e as salas" (Mário).

"Espero que melhore, né, tipo assim, em termos de escola está bom, mas pode melhorar, né. [...] que a escola se abrisse, oferecesse mais atividades, como esporte, que tivesse uma recreação pras crianças. Esporte é melhor 
pra qualquer um. Esses meninos ficam por aí o dia todo, podia estar ocupando melhor o tempo, e aprendendo porque o esporte ensina muito. Dá disciplina, socializa, né? [...] Alguns professores tinham que ser mais da comunidade, não assim, meio general" (Miguel).

\subsubsection{A concepção dos agentes institucionais}

Para os professores, a escola tem como função a transmissão do saber acumulado e a reprodução da sociabilidade. Nela, as pessoas aprendem, ensinam e se relacionam com as outras pessoas. Para a diretora, a escola deve oferecer os conhecimentos básicos, estabelecidos no Programa Oficial da Secretaria Municipal de Educação, mas fundamentalmente preparar para a vida. Todos os agentes comentaram, em diferentes momentos, a importância de ter uma escola na comunidade. Um professor acrescenta a necessidade de possibilitar o acesso às tecnologias da modernidade.

"A questão da internet, preparar os alunos para utilizar as novas tecnologias, você tem que passar pra eles isso aí, faz parte da cultura universal, né, usar um aparelho uma câmara digital, ou uma TV moderna essas coisas tem que se levar também pra quem mora na zona rural" (Prof. Jacó).

Os agentes institucionais indicam diferenças entre escola rural e urbana, principalmente em termos de rendimento dos alunos, de recursos, de participação dos pais.

\footnotetext{
"Você pode perceber, assim, a gente tem uma diferença muito grande entre o aluno que ta na rural, e o que ta na urbana, a gente vê que ele tem essa diferença, eles dois. Eles são diferentes, principalmente no desenvolvimento, no psicológico dele, é diferente, o investimento dele é diferente [...] porque os meninos da urbana eles são mais desenvolvidos, são mais ativos, eles lá não, são tímidos, eles já são assim mais retraídos [...] outra coisa que tem é que na rural eles (os pais) são muito participativos" (Profa. Diva).

"Porque muitas vezes o professor chega lá, ele fala: Ah! Escola rural? É fácil. Mas quando chega lá ele vê uma outra realidade, é uma realidade totalmente diferente do que ele pensa, o trabalho é diferente, a gente tem uma realidade que você vai fazer outro tipo de trabalho, e até outra metodologia" (Profa. Sônia).
}

Apenas uma professora comentou não ver diferença entre esta escola e as escolas de periferia em que trabalhou, observando apenas uma diferença.

"Não vejo diferença nenhuma, não, a evasão é a mesma, o índice de evasão é o mesmo, o índice de reprovação, de desinteresse, tudo é, assim. Realidades quase que idênticas, porque..., eu não senti muito a diferença 
porque esses anos todinhos eu sempre trabalhei em periferia, entendeu, [...] e isso aqui já ta praticamente uma periferia. A única, é..., diferença, assim, não na criança, mas assim, em termos de comunidade, né, porque eu acho que aqui a rural é mais participativa do que na periferia. A periferia já deixa mais de lado ainda na, no acompanhamento, aqui nesta escola, nesta comunidade, eu vi assim mais aproximação da família” (Profa. Lúcia).

Os agentes institucionais reconhecem a importância do bom profissional, sendo este considerado o que se dedica aos alunos, o que tem compromisso com a escola e com a educação. Os profissionais contratados acrescentam o compromisso com quem lhes confiou o cargo.

"É uma escola boa, que os professores tão se dedicando aos alunos, porque os alunos não ficam ao léu, por que muitas vezes os alunos ficam por aí, quando vê já ta no portão, e do portão perambulando... Aqui, a gente tem aquela responsabilidade muito grande com eles [...] a gente vê, é que tem uma boa referência da nossa escola, quer dizer, a gente gaba muito dessa escola, graças a Deus que ela é bem vista. Porque a pior coisa que tem é uma escola mal vista, é uma referência assim ruim, e aqui, graças a Deus, tem boa referência. E cada vez parece que aumenta mais" (Profa. Diva).

"Mas ai é que ta, é meu lado profissional, meu nome, o nome da direção da escola, a confiança que a diretora colocou em mim, então eu tenho que desenvolver um trabalho" (Profa. Sônia).

"Porque todos os professores tratam muito bem os pais, toda mãe que vem, aqui, todo mundo com alegria, com um sorriso, porque tem professores que quando chama, "pois é, mãe, seu filho tal, tal!", porque tem professores que chegam assim. Aqui a gente não chega assim. A gente vai explicar, vai conversar, e isso é uma coisa boa pra escola" (Prof. Jacó).

Para isso, enfatizam a necessidade de gostar da profissão:

"É bom a gente trabalhar na rural, mas a gente tem que trabalhar com amor e dedicação, porque se for por dinheiro, até logo. Não paga, não. Não paga, não paga o sacrifício que a gente faz, o empenho que a gente tem que ter, a gente tem que trabalhar pra se empenhar mesmo, porque senão no final do ano não tem o resultado. Vou dizer vou pra lá, vou pra lá porque vou pegar meu dinheiro no final do mês e não vou fazer nada. Ah! Não fica! Você não consegue ir pra lá pra rural. Por que que a rural, ela é um pouco defasada de professor? É por isso!” (Profa. Diva).

"Ai reclamam: ah! Aqueles alunos, que andam sem tomar banho, vêm assim tudo fedendo, ai, ave Maria! Tem colegas minhas, que trabalham na urbana, e diz, aqueles alunos? Ai! nem chega aqui, vai, vai, vai. Pior que é, é criança, você sabe que isso acontece, imagine aqui na rural, né. Então você tem que gostar" (Profa. Sônia). 
Os professores atentam para as dificuldades decorrentes de infraestrutura, das condições de isolamento, da falta de assistência e dos problemas familiares. Consideram que a escola rural é desprivilegiada, e que há certo descaso por parte das autoridades com a educação do campo, privilegiando o ambiente urbano. Faltam verbas para proporcionar melhores condições de trabalho, acompanhamento pedagógico e apoio para lidar com as dificuldades. Outro problema refere-se à rotatividade de professores. É preciso oferecer condições para que se possa desenvolver um bom trabalho.

"Todo investimento de bens, de materiais, de alimento, de material didático, de não sei o quê, vai-se primeiro para a urbana, para depois ir pra zona rural. As sobras, aquele que vem menos, porque são menos pessoas, então, há um certo descaso [...] O professor se vira. Às vezes solicitava e a Secretaria de Educação tendo, conseguia alguma coisa [...] vai muito da criatividade, da boa vontade do professor" (Prof. Jacó).

"Então tem a dificuldade de acesso para a SME chegar e fazer acompanhamento com a gente, às vezes não tem como mandar material pedagógico, dar apoio para os alunos, essas coisas, principalmente quando ta seco. Olha! Nós aqui já temos energia, mas tem escola que passa assim de meses sem ter até combustivel [...] Porque muitas vezes o professor chega lá, ele fala: Ah! Escola rural? Mas quando chega lá ele vê uma outra realidade, é uma realidade totalmente diferente do que ele pensa. Chega lá e ... Olha, foi no ano passado? Não, foi quando eu tava lá, em 2003. A Ana Maria, que era do distrito, ela levou 25 professores pra ficar, na área ribeirinha. Você veja que ela foi no motor com os 25 e voltou com os 25 , nenhum quis ficar. (...) quando viu a situação... Não! Assim eu não fico! Na época tava quase seca, aí viram aquele barrancão pra subir, ih! Aqui!!??? Não tinha onde dormir, tinha que dormir dentro da secretaria da escola. E a ribeirinha ficou sem professor" (Profa. Diva).

"Muitos professores só trabalham na área rural por falta de opção. Eu tenho colegas minhas que estão esperando ser chamada agora. Aí eu fiz essa pergunta, por que tu escolheu a, por que tu quer ir pra rural? Porque sempre alguma coisa te chama, né. Eu, pelo fato que sou RDA, e quanto mais eu puder me esconder melhor (pergunto o que é RDA) Os professores que não são concursados" (Profa. Sônia).

Se por um lado há dificuldades e desvantagens, também falam das vantagens:

\footnotetext{
"Mas eu gosto muito de trabalhar na zona rural, justamente, é, por exemplo, é tudo mais distante pra gente, mas, tem essa facilidade da comunidade, o povo mais simples é mais acessível, você chegar, conversar e tudo, entendem muita coisa, até eles querem. Tem a vida saudável [...] Mas é muito bom. Ali, na escola, assim da escola zona rural, mesmo de quinta a oitava, que são os maiores, é uma raridade acontecer uma briga, uma confusão, sabe. É, é, porque, não tem aquela cultura da violência da cidade, não é..., e quando aparece é um ou outro caso simples que você acabou ali na hora, não tem inimizade, não tem eu vou te matar, eu vou te não sei o quê ou chegam com arma na escola, uma raridade alguma coisa" (Prof. Jacó).
} 


\subsection{Expectativas dos moradores em relação à escola/escolarização}

No que diz respeito à escolarização, os moradores veem a escola como local de aprendizagem, e como via de ascensão social. Aspiram melhorias e depositam na escola a possibilidade de adquirir os conhecimentos necessários para alcançar profissões mais valorizadas e melhor remuneradas, bem como a formação de condutas e valores exigidos pelo mercado de trabalho nas cidades.

"É importante, né, antes a gente tinha que levar os filhos lá embaixo, agora não, é aqui perto. Sem o estudo, a gente não vai pra frente" (Graça).

"Ah, a gente aprende muita coisa, né. Vai pra escola pra aprender" (Rosa).

"Eu me esforço, trabalho, faço tudo pra eles estudarem, porque eu não tive muito estudo, a gente não valorizava muito, não tinha aquele pensamento de que o estudo era preciso. Mas hoje eu vejo que sem estudo não consegue nada, se eu tivesse estudado, [...] ai tinha como ter um trabalho melhor, tipo pra trabalhar no distrito; até pro comércio, tem lugar que eles pedem o certificado" (Raquel).

"Espero pra minha filha que ela saiba, que a escola saiba trabalhar a minha filha, pra que ela tenha um bom desenvolvimento na sociedade, que ela, saiba desenvolver, é, os pensamentos que ela tem na cabeça, saiba ajudar, isso, pra que num tenha... que ela tenha um futuro melhor, melhor que eu, né?" (Wilma).

Os moradores não querem que seus filhos sofram por não saber ler e escrever. Não querem a história de exclusão que tiveram. Na medida do possível, empenham-se em manter os filhos na escola, mas sabem que são pequenas as probabilidades de longa permanência, ou de que esta promova mudanças significativas na vida de seus filhos. A expectativa é de que a escola seja veículo de promoção social, para que seus filhos possam conseguir profissão diferente da sua.

"Olha como eu estou, cansada, mão calejada, cara preta de tanto tomar sol [...] Já meu filho, ele pode ter uma vida melhor, arrumar outro emprego na cidade, e não precisar ficar debaixo de sol" (Raimunda).

"Acho que na escola meus filhos podem conseguir mais coisas do que eu, pois vida assim, de dureza, eu não quero pros meus filhos" (Mário).

"Eu me preocupo com o futuro, o futuro de minha filha. Penso que é muito importante pra ela, ter uma vida diferente, e pra isso tem que estudar, né? E o estudo é uma preparação pro currículo da gente. Eu quero colocar minha filha no menor aprendiz" (Wilma). 
Os pais referem-se às dificuldades que possuem em acompanhar a escolarização dos filhos, tanto no que diz respeito aos conteúdos curriculares quanto à própria presença física, e remetem à escola esta possibilidade. Principalmente para as mães que trabalham fora de casa, é também uma forma de ocupar os filhos, deixá-los em lugar seguro, que de algum modo possa suprir aquilo que elas não podem fazer.

"A gente ajuda, né, quando pode. Eu tou sempre falando pros meus filho, vocês aproveita tudo o que o professor fala, porque a mãe não pode dar muita atenção, e tem coisas também que a gente não sabe explicar direito" (Rosinete).

"Eu nunca fui boa em matemática. Até que essas contas aqui eu faço com ela, porque isso eu sei, né, é do primário, e eu estudei até a quinta série, eu posso ajudar. Mas o (filho) lá da outra escola eu já não dou conta” (Rosa).

"Até um dia eu falei, conversando com a diretora, se seu pudesse, eu acompanhava meus filho cada aula. Só que eu sou a mãe e o pai, tenho que trabalhá. Mas ali eu estou”. (Raimunda).

"Nossos filhos estão vindo pro colégio, aqui no colégio eles tão bem guardados, porque estão na responsabilidade dos professores, da diretora e nossa responsabilidade também, porque eu sou cozinheira, mas eu estou de olho nos filhos de vocês aqui, né” (Maria).

Suas expectativas também incluem esperar dos filhos que correspondam e possam ter capacidade para estudar. Em alguns depoimentos, os pais instruem seus filhos para obedecer e atentar ao que os professores falam.

\footnotetext{
"Quando eles chega, eu pergunto, como vocês foram no colégio, às vezes ele diz, a professora fez isso, eu não gostei. Não! Ela ta fazendo o bem pra você, porque você está lá pra aprender" (Raimunda).

"É certo que criança tem que obedecer, tem que respeitar o professor, que ta lá pra ensinar, pra mostrar o conhecimento. Tem gente aqui que o filho chega falando e vai logo acreditando, e ficando brabo, querendo até brigar com a professora, mas a gente sabe que tem menino que apronta [...] Então, eu digo pra minha filha, se o seu colega quer ficar fazendo bagunça, vai, senta em outro lugar, e presta atenção no professor" (Miguel).
}

Para alguns moradores, a escola é basicamente lugar de aprender a ler e escrever, e isso é questionado quando o aluno não aprende.

\footnotetext{
"Se meu filho passa o ano inteiro e não sabe, mal seu nome, para que serve ir à escola?" (Graça)

"Aula, ele vai pra aula, mas a professora não da atenção, dá pros outros, né. Ele devia ir mais pra frente, né, que ele, sabe menos que os outros, mas
} 
lá, ele fica lá trás. Aí no final das contas, né, ele ia reclamar, que não fazia nada, nem ligava pro menino, né, eu achava errado isso ai" (Paulo/relato extraído da fala de um pai, durante o período de observação).

Observou-se a preocupação com a continuidade dos estudos. Em conversas com pais de alunos realizadas durante as observações, emergiu como preocupação o fato de não haver, nas proximidades escola de Ensino Médio. Os pais esperam que seus filhos possam seguir na carreira acadêmica pelo menos até o Ensino Médio, mas comentam sobre a dificuldade de mantê-los, pois aumentam os custos com passagem, alimentação, uniforme e material. Ainda assim, constatou-se no discurso dos pais haver um esforço por parte da família, apostando nesta continuidade, principalmente quando o filho manifesta interesse em estudar, sendo percebido como o que dá pro estudo, o que tem cabeça pra estudar. Em outros casos, fica por conta do próprio jovem manter-se nos estudos, podendo trabalhar durante o dia e estudar à noite. Constatou-se na comunidade a existência de jovens que, em torno dos dezesseis anos já constituíram família e/ou abandonaram os estudos para trabalhar. Os pais lamentam o fato, desejando que o filho um dia volte a estudar.

"Eu to estudando agora, a gente até se diverte bastante na aula. A Ana é que é nossa professora lá. Ela botou a gente pra fazer uma peça (risos) ta muito engraçado. Já falei pra Eliane (sua filha mais velha), cuida logo, vê se estuda, você ainda é nova, deixa os meninos aí que o Mário ta em casa, e a Joseane fica com eles" (Carla).

Apenas uma das mães entrevistadas comentou sobre a continuidade dos estudos em nível superior, e suas preocupações com a dificuldade a este acesso.

"Olha só, eu vejo por mim, que estudei por aqui até a oitava (série). E a gente vê como é que ainda está esse lugar, quem estuda aqui tem muita dificuldade de seguir, o ensino aqui é fraco. Sem falar no sacrifício que é estudar lá pra fora, eu fiz o ensino médio no Brasileiro, pegava ônibus todo dia às cinco, cinco e meia, porque se chegasse atrasada não entrava. Quando o ônibus quebrava era melhor voltar pra casa. Uma vez nós fomos, eu e o filho da Raimunda, e outros lá da Vila, a gente foi no ônibus. Já começou vindo atrasado, aí deu um problema logo ali na estrada [...] demorou tanto que a gente voltou nele, porque... ia fazer o quê na porta da escola? E a gente sabe, quando isso aqui vai melhorar? Eu penso em sair daqui pro meu filho ter mais oportunidade, eu quero fazer faculdade, mas estou vendo, [...] não tenho coragem de fazer o vestibular, porque sei que não vou passar. E hoje em dia, precisa fazer outras coisas, um curso de informática, de inglês, aqui é tudo muito longe” (Erilene).

Neste tópico, observou-se o que pensam pais e agentes institucionais sobre a escola, em termos de sua importância, e as expectativas que nela depositam. O que figura é que uma 
boa escola ensina, transmite conteúdos, tem bons professores, trata bem a comunidade. Observou-se a preocupação com as (im)possibilidades na escola rural, com a continuidade dos estudos, e com as dificuldades para implementar esta continuidade.

\subsection{A Participação}

A relação escola/família/comunidade é o tema do "Projeto Temático 2008", e tem como meta promover a integração entre escola e comunidade, bem como constituir-se num instrumento de reflexão e ações sobre as “questões sociais básicas”. Para tanto, propõe-se “conduzir os alunos a participar da vida em comunidade e da comunidade”. Também enfatiza a importância do envolvimento e participação dos pais na vida escolar de seus filhos:

Considerando-se que uma escola transformadora é aquela que está consciente do seu papel político na luta contra as desigualdades sociais, e que assume a responsabilidade de um ensino eficiente para capacitar seus alunos na conquista da sua participação social, cultural e reivindicação social, pretende-se oportunizar e obter o envolvimento dos pais na educação dos filhos, conscientizando-os da importância da participação de cada um na vida escolar do aluno.

O Projeto Temático cita a importância da integração e participação da comunidade, mas não oferece maiores informações sobre em que consiste tal participação e o modo como isto deverá ocorrer. Conforme depoimento da diretora, da merendeira e dos professores, a escola tem procurado estimular a participação dos pais e consideram estar tendo êxito. Relataram que obtiveram resultados mais efetivos, principalmente ao final do ano 2008. Para a diretora, este ano foi bastante conturbado, em função das trocas de professores e da campanha eleitoral para cargos municipais, mas isto a estimula a lutar ainda mais por melhorias. Houve muitos momentos em que teve de ausentar-se da escola, e não pôde dedicar-se ao acompanhamento pedagógico, como nos anos anteriores. Apesar disso, enfatizou os investimentos da escola no sentido de fortalecer cada vez mais esta integração/participação, pois a escola é uma só equipe e mesmo em sua ausência os professores e funcionários dão continuidade ao trabalho.

Os professores consideram que as comunidades rurais são mais participativas, mas que em termos do acompanhamento do aluno, os pais encontram maiores dificuldades, havendo também os que não participam. 
aqui nesta escola, nesta comunidade, eu vi assim mais aproximação da família [...]. Mas eu te digo assim, a participação, em termos assim, duma reunião, entendeu? Mas assim, em termos de a gente chamar o pai do aluno e eles virem, de imediato não, eu digo a participação num todo" (Profa. Lúcia).

"Eles são participativos, eles reivindica, eles vão, quando tem problema com os filhos, né, eles vão lá, conversar, perguntar por que que o filho não aprendeu, por que que ficou, muitos assim; mas é 50\%, não tem aquele 99\%. É $50 \%$ dos pais. [são participativos?] Eles pergunta, eles vão fazer, assim, quando tem limpeza da escola, né, eles ajudam, limpar a escola, lá, ao redor da escola, pintar [...] quando manda chamar eles vem, tem reunião eles vem, participar" (Profa. Diva).

"É, eu acho que ta melhorando, porque quando cheguei, eu achei, não via aparecer nenhum pai nem nada aqui. Bom, mas já aparecem mais, já vem mais interessados, na reunião já, já tão mais conscientes, conversam com a gente, e a gente não sente mais essa revelia que eles tinham com a escola [...] até na última reunião nós vimos que, quando ela (diretora) perguntou se tinha alguma coisa pra falar, se tinha alguma coisa a reclamar, se tinha..., falou umas duas três vezes, ninguém falou nada, então você já vê que é um processo que vai" (Prof. Jacó).

Para os agentes institucionais, a escola deve promover o bom relacionamento e com isto conquistar a comunidade. Há a preocupação em promover situações de acolhimento dos pais.

"[...] de ser amistosos com eles, de recepcioná-los, de conversar, e, e, abertamente, e do diálogo, e dizer que olha nós somos tudo um grupo só, uma uma família só com a mesma intenção, o que vocês querem pro filhos de vocês nós também queremos, né. É, então vamos trabalhar para essa causa, vamos, então eles sentem que você mais ta dando mais atenção, que você gosta dos filhos deles, que, não é, a escola, e isso vai melhorando um pouco mais esse relacionamento" (Prof. Jacó).

"Principalmente agora, que a gente começou a trabalhar assim com o escola-comunidade, né, mais ainda a participação deles, porque toda reunião que a gente faz, a gente diz, a gente pede, né, a aproximação deles. Eu acho assim, que eles ficaram mais próximos mesmo da escola, eles se sentiram mais apoiados, os pais. Porque toda reunião que a gente faz é assim, a gente sempre pede apoio, pede que eles, se tivé algum problema, que venha falar com a gente" (Profa. Diva).

Pensando sobre o que contribui para esta maior participação, consideram que a escola procura oferecer condições para isto, mas que é uma característica das comunidades rurais.

"Eu acho que sim, eu..., olha! Lógico que a escola contribui, mas eu acho que é a comunidade em si, pelo fato de ser tudo pertinho, né, então..., não é todo dia que a gente chama, então acho que é por isso que participam mais", (Profa. Lúcia). 
"As comunidades rurais são mais assim, você pode ver, se tiver alguma que não seja, é pouca, ela está mais próxima, por causa que a comunidade é pequena, todo mundo se ajuda; a professora, a escola, também faz parte da comunidade" (Profa. Diva).

Questionados sobre o que consideram participação, respondem que sempre convocam as reuniões de pais, conforme o calendário estabelecido, e convidam para as festividades promovidas pela escola. As festas são consideradas o ponto culminante da proposta pedagógica da escola, momento pontual de integração escola-comunidade e de avaliação do trabalho desenvolvido por professores e alunos.

Para a diretora, um dos objetivos em solicitar a maior participação, entendendo esta como a presença nos eventos que a escola realiza, é promover situações de acolhimento aos pais, oferecendo-lhes informações sobre como lidar com os filhos. Mas também considera que a efetiva participação dos pais pode contribuir para a educação de qualidade, pois envolve acompanhar o desenvolvimento dos filhos e continuar em casa o trabalho desenvolvido na escola. Entende que os pais possuem muita dificuldade neste acompanhamento, e por isso, a culminância envolve a realização de vários eventos. Em seu discurso, a diretora comentou sobre o interesse em construir uma gestão participativa, mas entende que isto está longe de acontecer, pois a comunidade é muito reticente e carece de organização política.

\subsubsection{A participação na perspectiva dos pais}

Os pais referem-se à importância da participação e consideram que esta envolve atender aos chamados da escola e o acompanhamento das atividades escolares, mas a maioria fala de suas dificuldades em acompanhar os filhos, limitando-se a comparecer às festas e reuniões, ou atender aos chamados da diretora e professores. Responderam que procuram participar, mas para os que trabalham nem sempre é possível estar na escola, mesmo assim, procuram saber o que aconteceu na reunião.

"Eu estou sempre na escola, participando. Não saio de lá, até porque a gente tava com a diretora naquela pendência da água, e depois disso estou sempre por lá pra dar força. Vou às reuniões, eles sempre fazem uma festinha, as crianças gostam quando a gente ta lá pra ver" (Carla).

Observou-se que esta participação como presença ocorria em alguns casos como obrigatoriedade, e em outros, o desejo de ser mais solicitado pela escola. Vale ressaltar o entusiasmo de alguns pais em participar dos eventos e mesmo de se colocar à disposição da 
escola, de estar fisicamente presente em diferentes momentos do cotidiano escolar e não apenas quando convidados. Esta presença é bem vista pelos agentes institucionais quando se deseja "contribuir", ou seja, quando a interferência não questiona os procedimentos adotados pela escola ou, se questiona, caminha no sentido de "compreender" o porquê de tal ação e pensar juntos em alternativas.

Os moradores falam da desunião como um aspecto que dificulta a participação. Os discursos apontam as diferenças existentes entre grupos de família existentes na comunidade, as influencias do clientelismo político, e ainda as influências religiosas, em que a união está acima de tudo e os conflitos devem ser evitados.

"A comunidade aqui ainda é muito desunida. Tem o pessoal de lá que não se dá com a Carla, e o pessoal dela são tudo esquentado, né. (...) eles não pensa que se todo mundo tiver junto, a gente consegue mais coisas" (Rosa).

"Pra participar tem que ter alguma coisa. Se for pra ouvir uma mensagem, se for só isso não vai ninguém, mas se tiver um brinde, um lanche, até se você distribuir cartelas pra um bingo, ai vai todo mundo" (Carla).

"Essa parte de participação aí na escola. É muito complicado. Tem pessoal aqui que é muito ignorante. Se o filho chega na casa da família e fala alguma coisa da escola, a mãe vai lá com a professora, brigar com a professora, ela não colhe primeiro informação do que foi. Agora você sabe, né, filho mente. Aí você acredita na mentira do filho, o que é que vai fazer?" (Miguel).

"É importante a participação de todos, mas eu já nem falo mais nada, porque aqui, depois ficam falando da gente, que a gente ta querendo conseguir alguma coisa, algum benefício. Tiramo dinheiro do bolso pra colocar esses canos ai" (Mário).

"Sou irmão dele, muito carinho com os meus irmãos, amo meus irmãos, não gosto quando ele fala. Não gosto porque aqui, nós temos quarenta e um, parente, né? E a coisa mais bonita é a união, eu preciso de todo mundo. Tem gente que diz ah, não preciso, eu preciso. Eu preciso. Aquele que diz que não precisa é o que vai precisar mais, não é verdade? O orgulho do cara, isso aqui é uma vida passageira. E aí nós tamos guardando o que afinal? Brigar, à toa, às vezes a gente fica olhando, brigam por uma besteira boba. Minha mulher mesmo diz que eu não sou por nada. Quando eu fiquei com a outra mulher, nós não. Tinha uma rede só. Dormia assim, um aqui jogado, era uma tijelinha. Nossa casa, nada, nada, nada. Aí, bora lutá pra frente, lutá pra frente" (João).

A participação parece estar restrita à presença física em reuniões, festas e outros eventos promovidos pela escola, ou na oferta de mão de obra em momentos solicitados pela direção, e sem explicitação de conflitos. A participação, como engajamento, aparece em ações e discursos ainda inexpressivos por parte de uma minoria. 


\subsubsection{Os espaços instituídos de participação}

Observou-se que a escola promoveu várias situações consideradas como estratégias de integração/participação, mas esta se restringiu à presença física nas atividades e eventos realizados, e o que figura instituído é que os moradores participem apenas de certos momentos da escolarização dos filhos, como expectadores, e quando solicitados. Mas também se constatou que a presença física nas reuniões aumentou conforme o decorrer do ano.

Nas reuniões de pais, observou-se que a diretora presidia as reuniões, apresentando uma pauta de informações. Iniciava com uma mensagem cujo tema referia-se ao cuidado e acompanhamento dos filhos, solicitando que alguém a lesse em voz alta, abrindo espaço em seguida para comentários. Após esta leitura, iniciava a pauta. De modo geral, as reuniões eram informativas. Foram poucas as vezes em que se trazia para a discussão algum tema a ser debatido e votado. Quando isto ocorria, as propostas eram apresentadas pela diretora, de modo a que ficassem bem esclarecidas, enfatizando-se que aquelas eram as opções mais interessantes no momento. Se alguma proposta diferente era apresentada, o direcionamento era efetuado, mas a diretora ouvia a comunidade e dizia que iria acatar as decisões tomadas pelo grupo, acrescentando que todos iriam assumir a responsabilidade pela decisão. A diretora explicitava seu interesse em que os pais se manifestassem, participassem, embora oferecesse certa resistência a idéias contrárias às dela.

Outro espaço instituído para a participação é o Conselho Escolar. Constituído por representantes de cada segmento da escola, quais sejam, professores, funcionários, alunos e pais, e o diretor, é o foro de decisões da comunidade escolar e da administração dos recursos que a escola passa a receber. O diretor preside o Conselho e seu cargo é vitalício. Os demais membros devem ser eleitos por seus pares em uma assembléia constituída exclusivamente para este fim.

Após a regularização/oficialização da escola, em junho/2008, a diretora empenhou-se em criar o Conselho Escolar. O momento dessa constituição foi marcado por bastante confusão. Dada exiguidade de tempo, a direção da escola convocou alguns pais e agentes institucionais para ocupar os cargos. Não houve tempo suficiente para esclarecer os pais sobre a função dos conselheiros, nem para organização de chapas e divulgação do processo, posto que todo o processo eleitoral deveria acontecer até o fim deste mesmo mês, em função das eleições para cargos públicos municipais. Constituiu-se uma chapa única e no dia da eleição ainda se faziam os preparativos. Os procedimentos não estavam claros nem mesmo para a diretora que, após determinado tempo, precisou explicar que todos os candidatos deviam 
receber pelo menos um voto para não invalidar a chapa. E assim, passou-se a indicar quem ainda precisava de votos. O clima era de entusiasmo por parte dos pais presentes, que procuravam colaborar com a diretora, atendendo às suas solicitações, e chamando quem passasse por perto para participar da votação. Os professores mantiveram-se nas salas durante todo este movimento. Durante o período em que estivemos na escola, não houve nenhuma convocação de reunião do Conselho Escolar. Meramente pro forma, todas as decisões foram tomadas pela diretora, após ouvir opiniões de alguns professores, principalmente no que diz respeito à aquisição de material permanente e de consumo, tendo em vista que os recursos eram limitados, e deveriam ser aproveitados da melhor forma possível .

Constatou-se que pais e alunos não participaram de nenhum momento de discussão e decisão sobre os projetos da escola. Também não observamos nenhuma ação no sentido de despertar o senso crítico para a participação efetiva nos problemas da escola. Mas um pequeno movimento se produziu, e é interessante registrar que ações pontuais dos pais, no sentido de sua organização e mobilização, evocaram questionamentos entre o grupo e reflexos nas práticas pedagógicas, o que pode possibilitar a construção de espaços para intervir.

De modo geral, observou-se que pais e professores, embora questionando determinados procedimentos, o faziam nas esquinas, não explicitando este descontentamento nos foros de discussão. Mas houve momentos em que a contestação tomou visibilidade, e destacamos dois movimentos: uma professora que questionava a centralização das decisões por parte da diretora, e pais que questionaram as atitudes de um professor com relação a seus filhos. A professora ficou somente quatro meses na escola, e solicitou remoção, argumentando motivos pessoais e principalmente de saúde. Os pais foram tranquiilizados pela diretora, que reafirmou com eles o compromisso da escola com a educação, acrescentando que todos os professores eram competentes e tinham o mesmo compromisso. Ouvindo atentamente as queixas apresentadas, ficou de averiguar a situação e falar com o professor.

Diante de impasses, a comunidade manifestou-se de duas formas: ou denuncia a escola às instâncias superiores, através do serviço disque-denúncia da Secretaria de Educação, ou retira o filho da escola. O posicionamento da direção é de tentar, pela via do diálogo, estabelecer o entendimento, a conciliação. Se isto não for possível, irá buscar amparo nas instâncias jurídicas. O relato de um professor sobre uma situação que envolve as ausências de um aluno ilustra esta situação:

"Ai se encontra uma faca de dois gumes pra quem é gestor da escola. Porque o que acontece? Você vai brigar contra quem, vai brigar com a comunidade? Você acaba tendo que fechar o olho e aí você também ta sendo 
um pouco negligente, no que você deveria salvaguardar do direito que seria da criança, né. Mas você sabe que se você fizer qualquer coisa a comunidade toda cai em peso em cima de você, porque ta indo contra, contra uma coisa, sabe? É uma situação delicadíssima. [...] A diretora, ela conversa muito, ela conversa, ela tenta passar, e a gente tem que ir pisando em ovos, pra não, sabe, é como teve um caso, dum aluno meu aqui que teve quase setenta faltas. E eu mandava chamar, mandava chamar, a mãe não vinha, e aí tive que mandar por terceiro, pra ir atrás da, chamar, aí foi que a mãe apareceu. [...] falei que ele provavelmente já pelas faltas, ele não vai; mas a senhora continue mandando, que ele, por lei, tem direito de estar na escola [...] aí deixou vir uns dois ou três dias e tirou, não mandou mais. [...] quando eu falei, ela (a diretora) disse ta vendo, Jacó, como é que é? A gente não pode nem falar com eles, porque numa situação dessas, eu sei. Retiram, e quem se prejudica é o aluno" (Prof. Jacó). 


\section{DISCUSSÃO}

Este capítulo refere-se à discussão de aspectos relevantes que emergiram com os resultados, e tem no Institucionalismo e na Filosofia da Diferença o suporte teóricometodológico para compreensão das questões e objetivos propostos nesta tese.

Percorreram-se trilhas construídas nos diferentes momentos de coleta de dados, misturando-as, envolvendo-se, marcando os entrecruzamentos de conceitos e experiências. Procurou-se organizar esta discussão a partir dos agrupamentos e temas propostos, entendendo que esta divisão não divide; é apenas uma tentativa didática para situar algumas questões que atravessam todo o processo.

Traçaram-se estas discussões considerando-se que esta história não se encerra na última linha, não se decifra na primeira leitura. É uma escrita, dentre tantas outras possíveis, que se faz coletivamente, com muitos interlocutores, desde as diferentes vozes presentes na trajetória da pesquisadora, os participantes que a ela se juntaram, no percurso de todo este processo de pesquisa, aos reencontros com os teóricos que desafinam sua lógica, revirando-a pelo avesso.

\section{Comunidade em ambiente rural-urbano.}

As sociedades não urbanas contemporâneas da Amazônia, apesar de grande diversidade, têm em comum uma relativa invisibilidade sociopolítica. É recente o reconhecimento legal da existência de estilos de vida tradicionais, cabendo aos organismos governamentais dedicar atenção necessária às suas necessidades e aspirações. São culturas originárias, autóctones, que efetuam uma agricultura tradicional, supostamente adaptada ao ecossistema, e cuja herança cultural passou a ser considerada valiosa (BARRETO FILHO, 2006).

Viver a cultura amazônica é encontrar-se com a diversidade, com diferentes condições de vida locais, de saberes, de valores, de práticas sociais e educativas, bem como com uma variedade de sujeitos camponeses (ribeirinhos, pescadores, índios, quilombolas, assentados, atingidos por barragens, e outros) e citadinos de diferentes matrizes étnicas e religiosas, em seus diversos modos de vida e interação com a biodiversidade dos ecossistemas aquáticos e terrestres da Amazônia. 
Realidades distintas, que não se apresentam como uma verdade a ser conhecida, mas como possibilidades de existir em um ambiente que continuamente se movimenta, e que potencializa maneiras amazônicas de estar no tempo.

O ribeirinho, como que à espreita, está à espera dos acontecimentos, atento aos eventos inesperados. A vida e as pessoas circulam com intensidades e durações que não ocorrem com a mesma velocidade da cidade. Opera movimentando "cabreirismos" e "leseiras-baré"19, e semelhante ao movimento salientado por Alvarez e Passos (2009) descrevendo o habitar em um território existencial, pode-se falar de um desligamento que não se confunde com dispersão da atenção.

Repouso dos movimentos automáticos e espreita aos eventos do acaso, [...] espera atenta, mas não ansiosa, ciente e respeitosa do tempo dos eventos e da necessidade de não atropelá-los (ALVAREZ E PASSOS, 2009, p.145).

Harris (2006) destaca que os ribeirinhos estão acostumados a descontinuidades temporais, ambientais e econômicas, movendo-se entre áreas rurais e urbanas, e acomodandose às condições do mercado, do mesmo modo como se adaptam às pressões ambientais. Povos que são capazes de se reorganizar e se reproduzir nas novas condições engendradas, num movimento que em muito se diferencia da "síndrome do loop ${ }^{20}$ ". Entretanto, ainda que a capacidade de abraçar a mudança em cada nova fase se apresente, sem que isso resulte no fim de seu modo de vida corrente, impactos significativos têm sido produzidos nestas comunidades, principalmente nas que, próximas aos grandes centros urbanos, passam a ser abrangidas ou mesmo subsumidas. Estes novos arranjos sugerem a produção de subjetividades capitalísticas, aprisionadas em devires homogeneizadores.

A comunidade estudada inscreve-se neste cenário heterogêneo, no entrecruzamento rural/urbano, em que os vínculos entre os moradores, os meios de subsistência e a edificação da vida em meio à natureza podem ser considerados como características do modo rural ribeirinho. Todavia, mudanças na comunidade sugerem a desorganização dos estilos tradicionais, que parecem deixar de despertar o interesse principalmente dos mais jovens, evidenciando uma estratégia de domesticação destes estilos pelo habitus da modernidade.

\footnotetext{
${ }^{19}$ Remetemos a estilos descritos por Márcio Souza, 1994.

${ }^{20} \mathrm{O}$ historiador Sevcenko compara ao loop da montanha russa, o dinamismo, a instabilidade e as qualidades fugidias de uma estética pós-moderna, induzidas pela capacidade técnica de produção, pela proliferação das mercadorias e pela fragmentação crescente do mercado. O loop é o clímax da aceleração precipitada, "sob cuja intensidade estrema relaxamos nosso impulso de reagir, entregando os pontos entorpecidos, aceitando resignadamente ser conduzidos até o fim pelo maquinismo titânico" (2001, p.16).
} 
A tradição oral anteriormente valorizada na transmissão de conhecimentos tende a ser desconsiderada. São poucos os momentos dedicados à cultura da conversa, oralidade dos mais antigos, que se utilizam dos espaços comunitários e religiosos para a transmissão dos saberes, dos valores e da tradição social. Não há mais interesse em manter as atividades agrícolas ou pesqueiras, emergindo como "opção" o trabalho urbano-industrial. Os conhecimentos aprendidos na prática e transmitidos por procedimentos de observação e repetição estão desvalorizados, creditando à escolarização a possibilidade de qualificação profissional.

O saber movimentar-se na sociedade urbana tem sido cada vez mais considerado, e a escola se coloca como espaço mediador, um dispositivo eficaz para assimilação de valores citadinos. A comunidade, antes espaço de socialização e aprendizado, tem cedido sua vez à escola, que assume a educação, alimentação, acompanhamento e saúde.

Os pais não se consideram mais responsáveis pela aprendizagem profissional, pois entendem que seus ensinamentos não dão conta de uma nova realidade. Mas, se por um lado esperam que a escola possa transmitir aos seus filhos a formação necessária para esta inserção, por outro, sabem que as oportunidades educacionais presentes no cotidiano dos alunos que habitam o meio rural não lhes conferem o suporte necessário a "bons empregos". Em função da baixa escolaridade passam a compor quadros de menor remuneração, submetendo-se à exploração.

O formato de loteamento e a separação entre este e uma área considerada privilegiada é outro indicador de mudanças que conferem ao espaço as estratégias mercadológicas; são espaços que se diferenciam dos tradicionais formatos ribeirinhos e que, representados de forma negativa ou como ambiente desfavorecido, ganham a dimensão de periferias urbanas. Com ele, configuram-se novas redes de relações e de poder que autorizam uns, mais do que outros.

O tempo e o ritmo, anteriormente marcados pelo regime das águas, precisam concorrer com novos regimes de temporalidade, homogêneos, que impõem a produção de novas subjetividades, e que, conforme Grisci (2001), somente se instauram a partir de um significativo controle disciplinar. Temporalidades que também contribuem para a emergência de um modelo potencializador de formas mais sofisticadas de acumulação, condizentes com o sistema capitalista de produção de mercadorias. Cidadania, democracia, e outros vinténs urbanos, tornam-se forçosamente conseqüências do ato de consumir individualmente.

Conforme Coimbra e Leitão (2003), o sistema capitalista produz diferentes dispositivos, instituindo e naturalizando territórios bem definidos. Um deles, o do saberpoder, identificado como lugar da competência, do conhecimento/reconhecimento, da 
verdade, dos modelos, da autoridade, do discernimento, da legitimidade e adequação de certos modos de ser. E outro, o do não saber, o da falta, caracterizado como território da exclusão, desqualificado, e até mesmo, como o que necessita ser acompanhado, tutelado e controlado. Enuncia formas de dominação que não se manifestam de modo simples e transparente, mas que imprimem nas e pelas subjetividades, formas de pensar, perceber, sentir e agir.

Citando Guattari e Rolnik (1986), a ordem capitalística produz os modos das relações humanas até em suas representações inconscientes: os modos como se trabalha, como se é ensinado, como se fala, etc.; fabrica a relação com a natureza, com os fatos, com o corpo, com a alimentação. Ainda conforme estes autores

[...] todos os que buscam produzir uma existência singular à normalidade vigente, geralmente assistem atônitos ao desmanchamento de seus modos de vida. Passam então a se organizar segundo padrões universais, que os serializam e os individualizam. Esvazia-se o caráter processual de suas existências; pouco a pouco eles vão se insensibilizando. A experiência deixa de funcionar como referencia para a criação de modos de organização do cotidiano: interrompem-se processos de singularização. É, portanto, num só movimento que nascem os indivíduos e morrem os potenciais de singularização (GUATTARI; ROLNIK, 1986, p. 38).

Universalizam-se desejos, ações e agenciamentos, esvazia-se a vida, diminui-se a potência e determina-se apenas uma única possibilidade de existência. É o mundo da representação, de existências sem cheiro e sem sabor. Sujeitos padronizados, cristalizados, que consomem produtos industrializados em série, e que praticam um serializado esforço cotidiano para continuar vivendo em série.

Os povos tradicionais têm um inegável reconhecimento e compromisso com a adoção de ações que cooperem para a conservação do ambiente natural, pois é o espaço de satisfação das necessidades básicas, espaço de lazer, de produção material, da memória e das tradições, enfim, fonte de vida. Este reconhecimento persiste atravessado por diferentes agenciamentos, em meio a novos modos de subjetivação e mesmo em face aos impactos que o próprio poder público conduz: impactos decorrentes da implantação de um assentamento com cerca de 300 novas famílias, removidas de ocupações urbanas, sem o acompanhamento mínimo de infraestrutura, para uma localidade no mesmo bairro, que possuía, à época, 180 famílias; obras de canalização de esgotos e de água servida em uma escola municipal que conduzem os dejetos, sem nenhum tratamento, diretamente para o curso d'água; obras que iniciam o que o poder público denomina processo de urbanização. Processo inconcluso e indefinível, estabelecido em planos que não envolvem a população local, e o deveriam, não só pelo grande 
conhecimento que possuem dos recursos naturais e de seus ciclos de reprodução, como também porque ali é o território de seu habitar.

A produção de subjetividades capitalísticas lança desafios. A atualidade aciona uma crise ecológica, e a relação da subjetividade com sua exterioridade encontra-se comprometida, segundo Guattari (2006), com um movimento geral de implosão, em que os desequilíbrios ecológicos são engendrados pelas intensas mutações técnico-científicas e pelo contínuo desenvolvimento do trabalho maquínico, que é redobrado na produção informática.

Esta crise repercute sobre as formas tradicionais de relacionamento e de uso dos recursos naturais, que parecem conduzir-se cada vez mais por uma lógica empresarial homogeneizadora. Associada à anuência e omissão do poder público, que não oferece os serviços básicos para o bem-estar social, intensifica-se a pressão sobre os recursos hídricos, favorecendo a exploração comercial.

Enunciações ecológicas passam a figurar em diferentes falas revestidas de sustentabilidade, mesmo que este termo não represente a mesma coisa para os distintos discursos. Todavia, apesar de se evidenciar uma consciência parcial dos perigos eminentes, as formações políticas e as instâncias executivas parecem totalmente incapazes de apreender essa problemática no conjunto de suas implicações; e este híbrido e insustentável discurso da sustentabilidade, ao privilegiar o "uso contínuo dos recursos naturais em bases ecológicas”, minimiza/desqualifica o acúmulo dos saberes tradicionais, expandindo lentamente a pressão sobre o ambiente.

Os moradores sentem-se distantes dos centros de poder, expostos aos caprichos de forasteiros e de decisões que nunca são tomadas em seu benefício. A seu modo, reivindicam o direito à diferença, experimentando tensões entre segmentaridades rígidas e linhas de escape. Há, segundo Harris (2006), um mérito entre eles, que consiste na capacidade de negociar com sucesso as condições do presente ("que sempre se ajeita") na busca constante por melhores condições de vida. Constatou-se que as lutas por infraestrutura na comunidade decorreram de processos de mobilização, e a própria construção da escola deve-se à luta dos moradores, em particular após a criação da associação comunitária, numa ação insistente, penosa e paciente, junto às instancias do poder público local. Estas ações precisam ser potencializadas a fim de favorecer os escapes, multiplicar os acontecimentos, criando formas de existência a favor do processo vital. Nas palavras de Rolnik (1995), trata-se de ouvir as linhas de virtualidade que se anunciam e se perguntar: que agenciamentos são passíveis de trazê-los à existência, e relançar um processo. 


\section{Escola rural em cenários pedagógicos.}

As escolas ribeirinhas têm as marcas dos habitantes do local, porque a construíram e nela empregaram sonhos, esperanças. São histórias marcadas por lutas, sonhos, projetos e persistências, objetivando o acesso, permanência e êxito escolar de seus filhos.

Nesta comunidade, a construção da escola deve-se em grande parte às reivindicações dos moradores por melhorias para a comunidade, incidindo primeiramente no atendimento ao Ensino Fundamental. Mesmo que não atenda às necessidades de todos os moradores (oferece apenas o primeiro ciclo do Ensino Fundamental), sinaliza um caminho, abertura para novas conquistas. Ter uma escola na comunidade é muito importante, pois agrega valor social, estreita relações com as outras comunidades, e proporciona segurança e comodidade. Sua importância pode ser dimensionada pelo tamanho da área destinada a esta construção, com expectativas de que seja o primeiro dentre outros estabelecimentos públicos.

Concordando com Côrtes (2004), assinala-se que o espaço escolar é duplamente construído: pelo poder público e por aqueles que o habitam. A inauguração deixa marcas e símbolos que remetem a população a um permanente vincular daquele espaço ao poder que o inaugurou, marcas que vão se apagando na mesma medida em que se apaga o compromisso destes atores das instancias executivas. Aqueles que o habitam vão, cotidianamente, construindo, transformando, adaptando-se às práticas e às realidades sociais. É território prenhe de significações, a começar pela possibilidade de assegurar um direito que por muito tempo foi negado aos trabalhadores rurais.

Há considerações interessantes com relação ao espaço físico, sobre o qual se passa a discutir, iniciando pelo entorno da escola e sua área externa. Descolado da exuberante paisagem natural, o prédio aparece em terreno árido, totalmente descampado, num cenário estático, sem colorido, com feições de abandono. É no mínimo curioso que não haja uma árvore plantada ou um pequeno jardim. Um sinal de que destoa da localidade ribeirinha, como se não fosse parte do lugar. A justificativa pela não utilização do espaço externo envolve a ausência de sombras ou coberturas que pudessem minimizar o impacto dos raios solares, e o fato de a escola não ser murada, o que dificultaria o controle sobre os alunos. De modo geral, as escolas ribeirinhas não possuem muros, e o entorno é espaço de circulação da vizinhança e dos momentos de recreio. $\mathrm{O}$ cenário parece se modificar em função desta interface rural-urbano, reterritorializando os agenciamentos. Já não se pode mais deixar os alunos circulando livremente, e a produção da existência envolve maior individualização e menor aproximação escola-comunidade. 
Trata-se, aqui, dos espaços, portanto, das visibilidades. Conforme Rocha e Uziel (2008), os agenciamentos concretos que se operam na escola envolvem o visível e o enunciável. A pedagogia refere-se ao enunciável como sendo o regime de linguagem que classifica, ordena e traduz o conhecimento. Já a escola diz respeito ao visível: constitui uma visibilidade, ou seja, é um regime de luz antes de ser um prédio concreto, um dispositivo que mistura programas e máquinas, que não se confundem com os objetos ou as coisas; são formas de luminosidades, "formas de luz que distribuem o claro e o obscuro, o opaco e o transparente, o visto e o não visto, etc." (DELEUZE, 2006a, p. 64).

$\mathrm{O}$ prédio foi idealizado num modelo que difere de outras escolas construídas à mesma época, como proposta de espaço e mobiliário para atender à demanda da Educação Infantil.

Ainda que apresente formato diferente, mantém um padrão estético, que acaba por uniformizar a grande maioria das escolas, obedecendo a um jogo de repetições estéticas que impede a constituição de múltiplos e diferenciados agenciamentos concretos, com seus tons, cores, sabores, que possibilitem a cada escola ter sua própria vida. Um elemento que toma visibilidade é a produção de cartazes, murais e ornamentos pelos agentes institucionais, mas principalmente pela direção da escola, sem a participação discente e menos ainda de outros membros da comunidade. A decoração dos ambientes encena os valores estabelecidos: "educar, socializar, criar, organizar, com liberdade e amizade". "Estimular compromisso, dedicação, criatividade e solidariedade”. "Não entre! Não faça..., não, não!”. Como visibilidade, os cartazes marcam as relações saber-poder. "Cartazes de combinados" que podem derivar de uma atividade de construção de autodisciplina, ou de uma prática burocrática envolta em um autoritarismo disfarçado.

Outro destaque refere-se à conservação do prédio e de seu mobiliário, que visibiliza a situação de abandono e indiferença por parte do poder público. A escola, como patrimônio da comunidade, fica à mercê do clientelismo ou de campanhas solidárias.

As grades evidenciam outra característica que parece atravessar as escolas na atualidade, marcadas por espaços fechados e controlados, separada do "mundo lá fora", com tempos determinados e obrigatórios para entradas, saídas e permanências. As grades chegaram à comunidade como parte da modernidade urbana. No mundo capitalista, torna-se necessária a proteção do patrimônio, e na escola, fundamentalmente, a proteção dos alunos, sob sua guarda e responsabilidade. "A janela mostrando o mundo, o quadro mostrando o nada". Ao ver um aluno que segurava as grades e contemplava o lado de fora enquanto a aula seguia seu curso, a escola nos lembra uma prisão. 
Os interiores apresentam a dimensão da vigilância e do controle. Foucault (1988) em seus escritos mostrou como o ambiente físico de uma escola pode servir ao controle do espaço, do tempo e do corpo, à ordenação do comportamento e à frustração dos desejos. Comparou a arquitetura das escolas às prisões, que tem o propósito de instituir o trabalho de vigilância, silenciamento e disciplinarização. Como assinala este autor, é o modo de dar, pela arquitetura, a transparência necessária à gestão do poder, possibilitando produzir uma nova coação, substituindo a força física pela eficácia de uma vigilância suave, sem falha, práticas incorporais de disciplina pela sujeição à norma.

A escola, em sua função de vigiar e disciplinar assemelha-se, portanto, ao pan-óptico, uma engenharia do poder, máquina abstrata imanente a todo campo social (DELEUZE, 1994), instituição perfeita do ponto de vista de seu potencial de vigilância.

Uma das características dessa moldagem é o esquadrinhamento do espaço. Para que o processo disciplinar se dê de forma mais proveitosa e intensa possível, torna-se necessário dividir e subdividir ao máximo, delimitando o espaço de dentro e de fora; e em seu interior outras divisões. Outra característica é a regulação do tempo, de modo a torná-lo inteiramente útil. Isto supõe uma economia do gesto, de maneira que, ao torná-lo mais preciso e rápido, será valorizado, medido em termos de minutos e segundos, e mais tarde quantificado pelos exames. É da técnica do exercício que emerge o corpo natural como objeto de saber, o qual deve ser dócil e disciplinado (FOUCAULT, 1988).

Os espaços têm destinação específica; afinal, o que se quer transmitir e ensinar precisa estar delimitado, ordenado e sequienciado. É responsabilidade de cada professor conter seus alunos nos espaços previstos para que cada atividade aconteça e para que cada pessoa, encaixada em sua respectiva categoria esteja produzindo. O imprevisível ou aleatório não são bem vistos, geram insegurança e incerteza.

O refeitório é o lugar dos fluxos, onde inevitavelmente todos se cruzam, e também onde o vigiar se inscreve de modo contundente. Seu formato hexagonal, se, por um lado, nos lembra os chapéus de palha, os encontros ao fim de tarde para rodas de conversa, momentos de intimidade coletiva, por outro, guarda esta função estratégica de vigilância e controle, pois por ele se acessam os demais compartimentos. Tal modelo possibilita a quem fica no refeitório uma condição de observar todo o movimento externo e interno, incluindo as salas de aula, quando as portas estão abertas. Como lugar de visibilidades, lá frequentemente se encontram os que estão colocados no lugar de vigia (locais de vigilância precisam de cargos de confiança). 
Adia-se o uso deste espaço para realização do que denominam atividades diferenciadas, adia-se a fluidificação, o movimento. Os limites do espaço físico, estabelecidos pelo modo como o utilizam, bloqueiam o recreio, mas isto leva a questionamentos: por que, na escola, as crianças têm necessidade de se re-criar? Por que se produziu a necessidade de um espaçotempo circunscrito?

Mesmo nos momentos de maior circulação e liberdade, é preciso controlar os impulsos do corpo. O corpo em movimento, em sua agitação afetiva e criativa, não é permitido, senão em espaços vigiados e observados, onde o professor evita misturar sua autoridade. Côrtes (2004), numa leitura foucaultiana, salienta que os fluxos tornam-se prisioneiros do olhar vigilante cerceador dos comportamentos que podem fugir aos padrões aceitos como normais, olhar que exige dos corpos ocupar os lugares a eles destinados, um local específico, distribuído cuidadosamente para evitar aglomerados confusos e proximidades indesejadas. $\mathrm{Na}$ expressão de Foucault (1988), uma arte das distribuições, normalizando corpos, exercendo práticas de individualização através da cuidadosa distribuição dos indivíduos no espaço e no tempo, distribuição que produz certa posição de sujeito, que os identifica enquanto grupo e enquanto indivíduos; máquina de fabricar subjetividades submissas.

Esta arte da distribuição se confere na organização das salas de aula aos moldes tradicionais, nas carteiras dispostas em fila, voltadas para a mesa do professor e para a lousa. O território do saber-poder marca as relações instituídas entre aquele que sabe e aqueles que não sabem; entre os que podem e os que devem falar apenas quando solicitados. E ainda nos uniformes, compondo o espaço e o controle. Como o nome diz, servem para uniformizar os corpos, torná-los todos "iguais", e impedir a manifestação das diferenças.

Chama atenção a distribuição dos turnos e horários. Alegando contemplar o critério demanda, instituiu-se uma significativa redução no tempo de escolaridade e no descanso de um professor em particular, que ministrava aulas nos três turnos. Entendemos que demandas são produzidas em função de necessidades também produzidas. Assim, questiona-se a que necessidades objetivam atender.

\subsection{As picadas por onde escapa...}

As normas para o uso dos compartimentos criados, são rígidas e restritivas quanto a determinados aspectos, como, por exemplo, a higiene na cozinha, ou o controle das chaves do almoxarifado e da diretoria, mas não tão rígidas a ponto de impossibilitar que linhas moleculares se rizomatizem, e que sobrevenham formas sutis de transgressão. Há fluxos 
distintos às imposições do poder hegemônico e uma miríade de pequenos poderes que atravessam o cotidiano, que fogem às linhas molares.

A sala da diretoria é o espaço da burocracia, e também das conversas mais íntimas, quando se necessita um cantinho reservado, e também das consultas a correspondências eletrônicas ou de elaboração de um material qualquer, pois lá se localiza o único computador da escola, e também dos aparelhos de ar condicionado que chegaram durante o mês de setembro, pouco antes das eleições, mas não foram instalados até o mês de maio do ano seguinte, e também espaço que se articula oposição aos candidatos indicados/exigidos pela gestão administrativa superior...

Uma administração que é preenchida por documentos e curtos prazos, mas se pode prover arranjos para dilatação dos mesmos. Entre matrículas, históricos, declarações e notas fiscais, há o apoio, o acolhimento a alunos e pais, as parcerias com lutas da/na escolacomunidade.

Os uniformes cedidos e exigidos pelo poder público municipal não impedem a entrada de um aluno quando não os utiliza. O chinelo de dedos e sandálias desgastadas, às vezes bem maiores que os pés que as carregam, compõem este uniforme.

Há poucos lugares reservados e como não há sala de professores, cada um reivindica como seu o espaço que ocupa. Mas é preciso dividi-lo com outro colega e o refeitório se faz ponte que atravessa portas.

Há recomendações para que os alunos não faltem ou cheguem atrasados, mas não há impedimento de sua entrada, principalmente por parte da direção. O importante é assegurar ao aluno estar na escola e dela tirar o melhor proveito; deve-se conquistar o aluno para que ele possa gostar de estar lá, impedi-lo de entrar seria opor-se a esta meta.

Não há exigência de filas, não há forma para cantar o hino nacional. Não há classe especial, afinal, de um modo ou de outro, todos já estão incluídos. São linhas que ampliam as fendas dos padrões e, ainda que sob alguns questionamentos, podem privilegiar outras possibilidades.

O controle também não bloqueia o café, espaço de encontro, de troca, de cumplicidade, de conforto e de apoio, em que se está para respirar, reclamar, chorar, falar mal de tudo e de todos, exorcizar demônios e voltar mais fortalecido para o dever, para o trabalho. Diálogos que produzem ações, silêncios, outros diálogos. Momento constitutivo em dispositivo analisador. 


\section{As práticas pedagógicas}

Neste ponto da discussão, trazem-se elementos das práticas, relações e situações que ocorrem efetivamente no cotidiano da escola, nos episódios rotineiros e triviais ou nos planejamentos e procedimentos organizacionais. Na expectativa de dar visibilidade aos mecanismos instituídos, problematizam-se as objetivações que aprisionam as relações e o desejo. Reafirma-se o cotidiano como uma realidade complexa, caracterizada por multiplicidades entrelaçadas, um campo de forças em permanente luta entre processos instituídos e naturalizados e as forças de invenção, engendradoras de processos instituintes.

As práticas pedagógicas enfatizaram o que se pode denominar práticas do bom saber, estabelecendo que é bom saber, mas que apenas determinado saber é bom (grifo da pesquisadora).

$\mathrm{Na}$ base desta concepção, está a referência/reverência a um saber legitimado, considerado universal, verdadeiro, incessantemente produzido e acumulado pela humanidade, e que deve ser transmitido pela escola. Esta perspectiva linear e evolucionista do conhecimento, fundada no modelo da representação, situa na educação via escolarização a possibilidade de sistematização e transmissão deste saber. A educação é entendida como " $o$ caminho para o atingimento destas formas mais elevadas da cultura, tendo por modelo as conquistas já realizadas pelos grupos sociais mais educados, e por isso, mais cultos" (VEIGA-NETO, 2003, p. 7). Estas concepções evidenciam as representações hegemônicas, que definem o mundo das representações, das estratificações, de territorialidades constituídas (DELEUZE, 1988).

Isto remete também a uma perspectiva que entende a escola, o aluno, o professor como objetos naturais, dotados de uma essência eterna e universal. A vida é tomada numa dimensão geral, uniforme, onde o não-similar, o não-assimilável, constitui uma ameaça ao equilíbrio estabelecido, sendo considerado um inimigo da ordem (Rocha, M., 2006b).

Sob esta visão, práticas foram encaminhadas para estabelecer uma escola como modelo de tamanho único, formato que deve se ajustar a todos, indistintamente, o que lhe dá um perfil com forte tendência para a padronização, formalização e hierarquização (TACCA; REY, 2008). Essa concepção de modelo necessário indica e fortalece a ideia de que todos são iguais e devem aprender as mesmas coisas ao mesmo tempo e da mesma forma, substituindose na escola o desejo de saber pela obrigatoriedade do saber. 
Sampaio (2006) considera que, mesmo já se encontrando presente nos discursos de professores e técnicos a visão de que as crianças, por serem sujeitos históricos, vivem de um modo bastante peculiar o processo de apropriação da língua, na prática, a expectativa ainda é de que todas aprendam pelo mesmo caminho. Para esta autora, no fundo, permanece a crença de que é possível determinar e controlar os tempos e os modos de aprendizagem dos alunos, moldando diversos tempos a um único, considerado como "norma" para todos, o qual gera descontentamento e insatisfação quando não se consegue êxito.

Nessa tendência à padronização, há conteúdos, regras, modos idealizados de se portar, valores absolutos em si mesmos. O heterogêneo emerge como termo depreciativo - "é uma turma muito heterogênea, que dificulta o trabalho docente". A possibilidade de conflito e do surgimento de outros caminhos deve ser neutralizada em todos os "entre" de alunos, professores, agentes institucionais e comunidade: entre tarefas, entre relações.

Constatou-se o predomínio de práticas conservadoras, individualizantes e rotinizadoras, fundamentadas na transmissão/recepção de informações, onde os alunos são basicamente ouvintes. Privilegiam-se a leitura e escrita, e a iniciação matemática. Os conteúdos são transmitidos de modo fragmentado e esquadrinhado, e o modo de trabalhá-los baseia-se na repetição e na cópia, sem apelo à reflexão ou ao potencial criador dos alunos. A estes, cabe receber e armazenar, caracterizando uma forte tendência à repetição mecânica dos conteúdos. É a escola do conhecimento que não leva a pensar, que teme a invenção.

Hashizume e Lopes (2008), referindo-se às práticas docentes em escolas rurais explicitam seu caráter homogêneo, fragmentado e hierarquizado: O homogêneo se evidencia pela lógica segundo a qual todos os docentes passam a adotar os mesmos princípios e critérios de ação, atitude que leva professor e alunos a criar o menos possível, pois tudo se resume a uma rotina que se repete. A fragmentação acontece com a manutenção da divisão social do trabalho na escola, perpetuando as dicotomias: concepção e execução, professor e alunos, o natural e social, e que acaba produzindo isolamento e fragilização de professores e alunos. Quanto à hierarquização dos papéis na escola, verificam-se as normas, regulamentos, decretos e calendários que impõem a aceleração, repetição e uniformização dos corpos, em detrimento do tempo vivido e da riqueza do ensinar, compartilhar, aprender.

A perspectiva evidenciada na proposta pedagógica não se sustenta nas práticas cotidianas, onde prevalece a unilateralidade do discurso e o trabalho coletivo é pouco exercitado. Constatou-se que os conteúdos são marcados pelo artificialismo, desconhecendo ou mesmo desqualificando o saber gestado nas relações do trabalho agrícola, e do ambiente ribeirinho. A estrutura organizacional e curricular é prioritariamente estabelecida a partir das 
ideologias predominantes nos centros urbanos, privilegiando a formação de condutas e valores exigidos pelo mercado de trabalho nas cidades, vendo a educação rural como um fragmento da educação escolar urbana.

A questão ambiental, tão presente nos discursos formais, é vagamente focalizada em ações pontuais, voltadas principalmente para os problemas urbanos. Práticas ruralistas sequer são mencionadas nos projetos ou atividades desenvolvidas pela escola. Estudam-se a fauna e a flora da região, sem fazer referência ao homem que ali habita, à sua história, seu trabalho e seu ambiente, colocando-o numa posição visível de inferioridade.

Como qualquer outro habitar, o ambiente rural educa, ao atravessar os sujeitos com seus fluxos que nunca se esgotam. Esse ambiente alfabetizador invade o cotidiano escolar, mas muitas vezes é interditado ou nele esvaziado em sua potência. A escola não entranha para si a riqueza do saber local, e carreia a visão exótica que se produziu sobre o homem da Amazônia.

A cópia, como dizem Fernandes et al. (2007), parece conspirar contra o trabalhar e o aprender. A criança gosta de falar de si, de contar suas histórias e sabe que a cópia extensa de qualquer coisa é apenas ferramenta para silenciá-la. Quanto à repetição, esta não necessariamente é um equívoco na aprendizagem.

Não há nenhum problema com a repetição, posto que é diferença. Extrai-se da repetição o que se diferencia a cada vez, pelas circunstâncias sempre diversas. Nas palavras de Deleuze, "a repetição nada muda no objeto que se repete, mas muda alguma coisa no espírito que a contempla" (DELEUZE, 1988, p. 127).

Repetir, em comunidades ribeirinhas, é manter-se em experimentação, e em muitos casos, é manter-se em contato com o saber acadêmico. Há relatos de moradores da comunidade que, mesmo aprovados, permaneciam na última série oferecida pela escola, "só pra não parar de estudar". Mas não se pode estranhar a apatia, a falta de interesse e de motivação, quando se trabalha somente com conhecimento pronto, e isso parece não impressionar mais os alunos ou mesmo os professores. Isso não é repetição, é "o mesmo" (DELEUZE, 1988). A dinâmica da vida social não para, os desafios são constantes, a ameaça está presente e a necessidade de viver empurra para a criatividade (ZIBETTI, 2005).

$\mathrm{Na}$ perspectiva do mesmo, para estar bem na escola, acertar, ser aprovado, é preciso reproduzir o modelo. Não basta pintar o desenho, ou fazer os cálculos matemáticos, é preciso fazer de modo que fiquem todos iguais. Aprender é não errar, ou errar cada vez menos para no erro não permanecer. 
A exigência de atenção concentrada foi outro aspecto enfatizado pelos professores. Entretanto, esta exigência, como elemento indispensável ao aprendizado, deve ser questionada. Para Kastrup (2004), os estudos clássicos sobre atenção enfatizavam seu papel no controle do comportamento e na realização de tarefas, sendo ela condição para o processo de aprendizagem e o desempenho de tarefas cognitivas. Funcionando como um processo a serviço da aprendizagem, a atenção restringe-se a objetos e estímulos do mundo externo, ou seja, para a captação e busca de informações, e qualquer falha é sinal de pouca atenção e baixa capacidade de concentração.

Esta perspectiva estreita a noção de cognição à solução de problemas, sendo a alternativa aos problemas de atenção declaradamente adaptativa, ou seja, deve-se promover a aprendizagem de uma atenção necessária à realização de tarefas.

Tomando por base a noção de cognição como invenção, a autora salienta que ao restringir a atenção ao ato de prestar atenção, identifica-se o processo de concentração ao de focalização, processos que não se sobrepõem, posto que pode haver focalização sem concentração e vice-versa. Enquanto aquela prevalece no regime cognitivo, que é hegemônico na subjetividade contemporânea (uma subjetividade marcada pelo excesso de informações em grande velocidade e que parece impor mudança constante no foco da atenção), a concentração sem foco revela-se indispensável no processo de invenção.

O exame cuidadoso e atualizado do funcionamento da atenção revela que esta não é um processo único e homogêneo. O prestar atenção é apenas um dos atos de um processo complexo, que inclui modulações da cognição e da própria intencionalidade da consciência. Enquanto atenção concentrada, a distração pode ter um papel positivo no processo de aprendizagem inventiva, não sendo mera desatenção e encarnando, em certa medida, o funcionamento da atenção como modulação da intencionalidade da consciência (KASTRUP, 2004, p. 13).

A forma de concretização destas propostas reforça a postura imobilista do trabalho, predominando a ritualização dos procedimentos que intentam transformar a aula no momento de silêncio, onde tem lugar a aprendizagem pela ordem, pelo esforço individual, que sufoca a rica experiência cotidiana do aluno. Isto certamente não ocorre sem questionamentos ou inquietudes.

Esta ritualização imprime a força do instituído, tentando impedir, mas somente limitando, as forças instituintes. Conforme Linhares (2002), o instituído orgulha-se de sua organização, instalada mediante percursos que vêm de um passado vencedor, quando, em algum momento, prevaleceram lampejos instituintes, mas que se cristalizaram. Sustenta 
conhecer o que pode dar certo e tributa aos movimentos instituintes ameaças de colocar a perder um modelo que não deve ser questionado. Por sua vez, as experiências instituintes estão sempre em "devir", pisando em terreno movediço, sem certezas e comprovações da História, mas enfrentando e infiltrando-se nas tramas instituídas, para aproveitar frestas e assim, afirmar a outridade, ou seja, uma escola que pode ser outra.

No ambiente escolar, há inquietudes que clamam por outros modos de organização/ compreensão dos processos ali vivenciados. Se há forças instituídas em ação, é porque há mecanismos instituintes com potencial de engajamento e mudança. A diferença está presente e pode, a qualquer momento, fazer valer sua potência política na heterogeneidade da vida diária escolar. Como diz Miskolci (2005), quando menos se espera, algo destoa, um aluno age ou se expressa de forma que aciona algum mal-estar e o que antes aparentava ser homogêneo, emerge como um corpo estranho, que rompe com o hegemônico, desafia as normas, colocando-as em discussão.

Para Abramowicz e Levcovitz (2005), a ação pedagógica concebida no cenário do suposto saber/verdade universal engendra práticas sociais coercitivas; nega a solidão, recolhe a vida para dar-lhe outra configuração, produzindo valores que consolidam o ideário hegemônico. Conforma processos de subjetivação que pressupõem a necessidade de sentar, calar e copiar para aprender, valorizando determinado jeito de ser, de brincar, de falar e de pensar.

Rocha, M. (2006a) vai dizer que a escola, produzida por uma lógica que homogeneiza, e, ao mesmo tempo, produtora desta mesma lógica, favorece a produção de subjetividades fabricadas, padronizadas, capturando sensibilidades. São alunos e pais descredenciados em sua potencialidade. São também professores desacreditados que marcam pela queixa seu fazer diário. O que se mostra visível é que a escola cumpre sua função em produzir subjetividades afinadas com a lógica do capital, distantes da autonomia e da expressão coletiva.

$\mathrm{Na}$ análise do modo como a escola se articula aos interesses hegemônicos, Fernandes, Rozenowicz e Ferreira (2007; 2004) falam de uma escola que tem expulsado a diversidade, ocultando e reforçando mecanismos de produção de desigualdade social,

[...] na medida em que não foi estruturada para permitir uma experiência educativa e cultural para a criança pobre. O sistema escolar se limita a ensinar suas próprias produções e a aprovar ou reprovar com base em critérios de precedência que ele mesmo definiu como mínimos. A escola alimenta-se de preconceitos sociais que vêem nas crianças pobres uma incapacidade para aprender e uma menor valorização dos estudos em suas vidas (FERNANDES; ROZENOWICZ; FERREIRA, 2004, p. 32). 
Outro tema que emergiu diz respeito à produção das dificuldades. Para os professores entrevistados, as dificuldades dos alunos referem-se à sua incapacidade de construir os conhecimentos acadêmicos e suas causas giram em torno, basicamente, dos clássicos temas presentes na literatura especializada: problemas individuais, familiares, afetivos, sócioeconômicos, o que, de certo modo, contrasta com a percepção dos moradores da comunidade a respeito de seus filhos.

Estas explicações desconsideram o processo de produção dos fenômenos, naturalizando o que é histórico e individualizando o que é da ordem do coletivo. Parece haver nas falas uma imagem do aluno ideal e, como diz Adriana Machado, o domínio do tempo verbal futuro do pretérito: "aquilo que a criança deveria ser e não é, o que seria bom que acontecesse. Um futuro possível se o passado fosse diferente. Nesse lugar, poucas rupturas podem ser criadas". (MACHADO, A., 2005, p. 72).

Vários estudos (PATTO, 1990; SOUZA; MACHADO, A., 1997; MOYSÉS, 2001) já sinalizaram que o fracasso escolar das crianças de camadas populares, e aqui também se incluem as escolas rurais, é produzido por diversas práticas que se estabelecem na relação da escola com a sociedade e com sua clientela, denunciando que o fracasso escolar não pode ser entendido como produção individual.

Ao formular que determinados alunos não aprendem, seja por apresentar deficiências decorrentes de suas condições de vida, alimentares ou de desestruração familiar, ou ainda pela falta de interesse dos pais nas questões escolares, os modelos hegemônicos atualizam a ideologia do mérito, do esforço individual, da racionalidade e do dom, e reforçam a ideia de que os problemas são exceção, produzindo práticas de exclusão ou, melhor dizendo, um outro tipo de inclusão. Como Machado salienta, vai dizendo nas entrelinhas quem fica e quem sai, demarcando as perspectivas de sucesso e fracasso escolar. "Naturalizamos a existência de perdedores que devemos ajudar, com se os mesmos fracassassem por motivações intrínsecas" (MACHADO, A., 2005, p. 78).

Fernandes et al. (2007), discutindo a produção dos alunos-problema, sinalizam a invenção, a partir da modernidade, de uma infância sem potência, que emerge juntamente com uma ciência capaz de dar sentido a essa infância. Constitui-se um conceito de aluno, sujeito sem poder, incapaz de gerar conhecimento e gerir sua aquisição, e submetido ao discurso pedagógico "que orienta horários e rotinas, hierarquiza relações, cria fronteiras entre os conhecimentos, indica os comportamentos ideais e legisla sobre os desvios (FERNANDES et al., 2007, p.151)". A autora definiu como "doença que não dói essa marca que como uma pele cola ao corpo da criança pobre colocando finitude a qualquer intenção 
que aponte para a diversidade e para o sucesso (FERNANDES et al., 2007, p. 147)”. São práticas que silenciam e petrificam os alunos, interditam o corpo em seu modo de funcionamento, atualizando a culpabilização da vítima.

Reduz-se uma multiplicidade de fatores a questões individuais, reforçando mecanismos ideológicos que se cristalizam e passam a compor as subjetividades, traduzindose em formas de relacionamento que produzem a dificuldade e seus culpados. As dificuldades são objetivadas, produzindo-se, assim, os incapazes, os tímidos, as necessidades especiais.

O que chama atenção, para Machado, A. (2007) é o congelamento das relações no território escolar, que impossibilita perceber que as práticas engendram subjetividades, naturalizando modos de viver, sentir, ver e ouvir. Remetendo a Foucault, a autora acrescenta que a objetivação de uma prática, implica em práticas de subjetivação, ou seja, produz-se algo e produz-se o sujeito que entende esse algo naturalmente.

A naturalização rotula os indivíduos, obscurece a dimensão das relações, e acaba por constituí-los naquilo que os discrimina, sem visibilidade para seus processos de singularização. Ao focalizar a dificuldade como inerente ao aluno, "coisa que existe em si", desconsidera-se a rede de relações, o campo de forças no qual se viabiliza sua produção. É preciso compreender os múltiplos fatores em jogo, pois os acontecimentos não existem por questões individuais, não são determinações diretas de fatos isolados. Não têm causas individuais, pois não são de ninguém. São efeitos que se engendram em uma rede de relações (DELEUZE, 2006b).

Os acontecimentos produzem realidades. Portanto, não há algo anterior e interior ao sujeito, separado daquilo que acontece. Não é possível uma explicação genérica para o funcionamento da criança, independentemente das relações. Não se está desconsiderando a existência de vários componentes, nem desqualificando saberes estruturados, mas cabe por em evidência que práticas engendram saberes, atribuem dificuldades e inventam epidemias. $\mathrm{O}$ desafio, como diz Rocha, M. (2000, p. 194), é transformar "o interlocutor que discute as formas constituídas em intercessor que faz alianças com as forças que se abrem para o inesperado, para experimentar outras intensidades".

Habitantes de outras espacialidades, em que o livre contato com o ambiente natural lhes impõe aprender ${ }^{21}$ diferentes estratégias, os alunos das escolas ribeirinhas encontram na escola um território de castração, de imposição de limites, de baixas expectativas sobre suas possibilidades de êxito, que vão lentamente lhes dizendo que este não é seu lugar. Em muitos

\footnotetext{
${ }^{21}$ Referimo-nos ao conceito de aprendizagem inventiva, de Kastrup (2004; 2008).
} 
casos, a criança ou o adolescente quer sair da escola, ir para a vida, como se esta não pudesse estar dentro da escola. Em outros, conseguem recriar num espaço que os nega; conseguem negociar e lutar por seus desejos e, de alguma maneira, conhecem as possibilidades de ocupação/transformação, infiltrando-se nas brechas.

$\mathrm{Na}$ conferência de abertura do IX Congresso Nacional de Psicologia Escolar e Educacional, Lino de Macedo (2009) falava que, na cidade, 50\% do cotidiano das crianças estão relacionados à escola. $\mathrm{Na}$ área rural, a escola é parte, a parte que as retira deste cotidiano. "As crianças estão misturadas, nos ritos, na atividade produtiva, livres, há muita tolerância. E os professores não entendem como parte de seu cotidiano, de sua cultura, mas como falta de educação" (informação verbal ${ }^{22}$ ).

Constatou-se a intolerância dos professores com as diferenças, as baixas expectativas sobre as possibilidades de êxito dos alunos e uma concepção que associa aprendizagem à obediência, fazendo da disciplina e do controle outro carro-chefe da escola.

Se, por um lado, verbalizam que não se deve discriminar por características pessoais, sexuais ou sociais, enfatizando a importância da cooperação, da solidariedade e de se conhecer as regras básicas de convívio social, por outro lado, o tratamento dispensado como forma de manter o controle e a disciplina ratifica modelos discriminatórios e autoritários. As expectativas cristalizam opiniões e práticas, e marcam de antemão destinos e modos de ação: os "bonzinhos" continuam sendo estimulados, os "atrasados" são deixados à sua própria sorte e, os "impossíveis", dispostos em um canto da sala e mantidos sob pressão.

A indisciplina, também aprisionada na existência individual, circunscrita ao domínio do íntimo e psicologizada (ROCHA, M., 2000), é percebida como obstáculo ao processo ensino-aprendizagem. E os comportamentos não aceitáveis dentro dos critérios dos professores, são considerados como os que devem ser controlados. Esse anseio de submissão confunde-se frequentemente com desempenho escolar, como se fosse preciso dobrar-se passiva e inteiramente às normas escolares para aprender. Na compreensão dos professores, ser um aluno disciplinado não é apenas ter bom comportamento e atender ao que lhes indicam, mas apresentar bons resultados no estudo.

É interessante pensar sobre os modos como vão se estabelecendo e cristalizando certas práticas de disciplinamento e controle presentes no cotidiano escolar. Remetendo a Foucault (1988), pode-se falar da escola como instituição profundamente remodelada por estas práticas, e que concorre enormemente para o agenciamento da subjetividade do homem moderno. Este

${ }^{22}$ Informação fornecida por Lino de Macedo na Conferência de abertura do IX Congresso Nacional de Psicologia Escolar e Educacional, em 2009. 
autor chama a atenção para o funcionamento de vários dispositivos disciplinares que foram se transformando ao longo dos séculos, com o objetivo de administrar e gerir os grupos de indivíduos, e garantir o controle dos corpos. E traz à tona a concepção do poder como algo que não apenas reprime, segrega ou exclui, mas também produz certos tipos de indivíduos, economicamente úteis, dóceis e disciplinados.

As práticas pedagógicas emergem como um movimento de disciplinamento das sociedades, em função de uma nova concepção de infância que aparece no Renascimento ${ }^{23}$. Em nome dos crivos moralizantes estabelecidos pela igreja católica, constituem-se aparatos de poder que ordenam os conhecimentos e estabelecem novas relações, passando o saber ao domínio dos mestres.

Conforme Veiga-Neto (2005), as escolas e seus currículos fundam historicamente seu envolvimento no processo de produção de subjetividades: ao se pretender universal e obrigatória, a escola progressivamente estabelecida na Europa, a partir do século XVI, tornouse o aparelho que, mais eficientemente do que qualquer outro, fabrica sujeitos modernos. Isso se deu porque a escola moderna - com seus rituais de espaços, tempos, poderes, permissões, silêncios, passagens, sua organização curricular - faz a ligação entre o poder e o saber.

Esta escola que nasce com a pedagogização dos conhecimentos, introduz um novo modo de pensar/fazer o sentido da educação, implicando a afirmação do estatuto de verdade e a luta de diversos campos de conhecimento pela legitimação científica, fundada no rigor metodológico. Para Foucault (1986), o saber/verdade e o poder estão intimamente associados, sendo que o saber/verdade produz poder e o poder produz saber/verdade. No contexto da cientificidade da Pedagogia, a organização curricular encontrou terreno fértil na disciplinarização.

A disciplina exerce um papel fundamental. O poder disciplinar, em vez de se apropriar e de retirar, tem, como função, adestrar. Ele não amarra as forças para reduzi-las, mas procura ligá-las para multiplicá-las e utilizá-las num todo. Para o autor, é próprio das disciplinas tornar o exercício do poder o menos custoso possível, fazer com que seus efeitos sejam levados a seu máximo de intensidade e estendidos tão longo quanto possível, para fazer crescer a docilidade e a utilidade de todos. Esse novo sentido de disciplinarizacão dos saberes instaura, a partir do século XVIII, os modos de subjetivação específicos do capitalismo.

A disciplina é a anatomia política do detalhe, sua característica é esmiuçar o que possa parecer mais insignificante, mais tênue. Não lhe interessa o fausto, os grandes feitos, mas os

\footnotetext{
${ }^{23}$ Cf. ARIÉS, P. História social da criança e da família. Tradução de Dora Flaksman. 2. ed. Rio de Janeiro:
} Editora Guanabara, 2006. 
pequenos atos anônimos sem proeminência, nem por isso destituídos de importância. $\mathrm{O}$ controle se estabelece pelo olhar, que é ao mesmo tempo centralizador, para o qual tudo converge, e descendente, porque capaz de espiar as menores ninharias. Neste aspecto, a disciplina precisa da pirâmide de olhares hierarquizados facilitados não somente pela arquitetura, mas principalmente por uma arquitetura de olhares escalonados em gestores, gerentes, agentes operacionais, merendeiras e auxiliares (FOUCAULT, 1988). Este autor salienta que o indivíduo, na modernidade, foi submetido a processos internalizados de vigilância. Assim, o controle é internalizado e o esquema geral da norma se impõe tanto subjetivamente quanto no cotidiano dos grupos e da sociedade, cabendo às micropenalidades modelar subjetivamente o corpo indisciplinado, de tal modo que o poder funcione espontaneamente sobre si mesmo e o controle passe a ser total. O controle é tão mais eficiente quanto funciona de forma invisível, ou seja, a ninguém ocorreria contestar, por ser naturalmente aceito por todos.

Mais do que uma microfísica celular, que caracteriza o indivíduo como indivíduo, como uma ordem dentro de multiplicidade, ou uma arte de deles extrair o tempo, a disciplina precisa compor forças para obter um aparelho eficiente, conseguir a colaboração deste corpo singular em articulação com outros, para que o trabalho seja mais produtivo. Na escola, por exemplo, permeiam questões do tipo como despertar atenção da turma, como controlar os alunos para o trabalho da aprendizagem, como ajustar o tempo de uns ao tempo de outros, ou melhorar relações interpessoais para uma maior produtividade.

Acrescente-se a fragmentação e divisão dos saberes possibilitaram a especialização dos professores, do material didático e do espaço pedagógico; permitiram o fracionamento do tempo em aulas estanques, e um rígido controle sobre o que o aluno aprende, como aprende e em que velocidade isso deve ocorrer. Tudo pode ser medido e avaliado (GALLO, 2004).

Para Foucault (1988), pares opostos de representações são formados, via mecanismos de punição, para marcar no aluno um tipo de saber que o objetiva. Nesse sentido, sabe-se exatamente que os alunos devem ser isto e fazer isto, e não devem ser aquilo e fazer aquilo. $\mathrm{O}$ elemento punitivo cumpre tanto mais seu papel quanto mais os alunos se identificam coletivamente com as regras de comportamento. A execução exata da ordem recebida, com a eliminação incondicional de toda crítica pessoal, envolve um agente preparado exclusivamente para a realização desta. $\mathrm{O}$ código disciplinar imposto pelos dominadores faz os dominados "desejarem" a dominação, vista como ordem legítima, dispensando a coação, pelo menos na extensão antes necessária. A vantagem desse sistema é que ele não precisa dispor de punição física para manter as coisas dentro da ordem. 
A disciplina preenche, através da norma, o espaço vazio deixado pelas leis, por sua impossibilidade de alcançar todos os escaninhos do comportamento. A normalização, como manobra que supõe um padrão, um modelo a atingir, produz um sistema de classificações que se refina e afina a cada dia.

E nesse afinar-se, as novas composições do social, marcadas pela velocidade e fluidez, delineiam estratificações outras, que em muito diferem do fordismo e do imperialismo de séculos atrás. Constitui um novo estágio do capitalismo, associado à assim chamada pósmodernidade. Há, com isso, formas mais sofisticadas de disciplinamento, das quais a educação faz uso na atualidade, expressões daquilo que Deleuze (1992) denomina sociedade de controle. Para ele, as instituições disciplinares cumprem ainda, bem vivas, sua função de concentrar, distribuir e ordenar no espaçotempo as forças produtivas. Os indivíduos continuam passando "de um espaço fechado a outro, cada um com suas leis: a família, a escola, a caserna, a fábrica, de vez em quando o hospital ou a prisão" (DELEUZE, 1992, p. 229).

Em seus apontamentos sobre Foucault, o autor fala de uma crise generalizada dos meios de confinamento, e de novas forças que se anunciam. São as sociedades de controle em complemento às sociedades disciplinares, e que a estas se sobrepõem. Nestas sociedades, novas formas substituem as antigas, trazendo como característica principal o confinamento dos sujeitos em meio aberto, ou seja, o controle, que anteriormente se verificava na circulação do indivíduo por espaços fechados da família para a escola, da escola para o trabalho, etc., passa a ocorrer no aprisionamento pelas novas tecnologias, pelos meios de comunicação.

Há novos arranjos tanto das visibilidades quanto dos enunciados, transformando a comunicação num imperativo inquestionável. Essas novas formas, além de ultra-rápidas, favorecem a incidência do controle ao ar livre, substituindo as antigas disciplinas, que operavam na duração de um sistema fechado. Nas sociedades disciplinares, os espaços internos dos estabelecimentos eram imprescindíveis para a incidência do poder disciplinar sobre os corpos. Nas sociedades de controle, o acesso aos corpos se dá de forma contínua e ilimitada, sobre o exterior e o interior, numa modulação contínua que os marca, fabrica, delimita, castra e calcifica. O controle é indiferente ao espaço extensivo, pois se realiza num espaço de comunicação em que os fluxos são modulados de acordo com as circunstancias e a liberdade individual ou coletiva é agenciada pelas potências de controle.

Deleuze anuncia que o próprio Foucault sabia da brevidade das sociedades disciplinares, que sucederam as sociedades de soberania, delas diferenciando-se em objetivos 
e funções: "açambarcar mais do que organizar a produção, decidir sobre a morte mais do que gerir a vida" (DELEUZE, 1992).

Nas palavras de Azambuja e Guareshi (2007), o controle sobre os sujeitos procede de forma contínua e por comunicação instantânea. A configuração social anterior ainda vigora, mas em roupagens muito mais sutis e detalhadas; uma modulação como uma rede móvel e alterável de um ponto a outro. É como se aqueles meios ditos fechados, distintos e descontínuos agora se misturassem e permeassem continuamente a vida cotidiana.

Nas sociedades de controle, os indivíduos tornam-se "dividuais", divisíveis, e as massas tornam-se amostras, dados, mercados (DELEUZE, 1992, p.222). Se, nas sociedades disciplinares, o poder é simultaneamente massificante e individualizante, nas sociedades de controle o que importa é a senha, a linguagem numérica, feita de cifras que estabelecem o acesso à informação, ou à rejeição, remetendo a trocas fluidas. Há uma mudança de regra no capital, que desvia da produção para a venda de serviços e compra de ações, e nesse modelo, o marketing passa a ser um dos principais instrumentos de controle social, tudo em curto prazo e alta rotação. Como o autor salienta, o domínio não se estabelece mais pelo confinamento, mas pelo endividamento.

Os artifícios de controle modificam-se, mas acabam tendo a mesma finalidade. Esse permanecer em controle supõe o preparo dos alunos para assim movimentar-se em outros espaços da sociedade. Modificam-se as relações de troca, gerando a massificação na comunidade do consumo de bens industrializados, as relações com o tempo, que passa a ser cronometrado pelo relógio, e com o corpo, produtivo, que precisa gerar renda. $\mathrm{O}$ corpo, em suas singularidades e potenciais, tende a desaparecer, por estar cotidianamente impelido a conectar-se com as necessidades do mercado global.

Fugir do controle não é resistir às potências, mas travar uma "guerrilha infinitesimal" contra elas, o que só é possível porque a linha criativa do desejo está sempre à frente das linhas de força do controle.

[...] linhas de fuga e de resistência que modulam agenciamentos do desejo como larvas de uma cólera contra a época, contra o intolerável e a favor da invenção de modos mais suaves de coexistência entre os entes (DELEUZE, 1992, p. 7).

Observou-se um fastio pela mesmice. Isso se apresenta no descontentamento em relação à assessoria pedagógica proporcionada pela Secretaria Municipal de Educação, na preocupação dos professores com alunos que não conseguem acompanhar o que se considera 
"o desenvolvimento normal para sua idade", nos esforços empreendidos na busca de apoio profissional, e na resistência à execução de um planejamento vertical não produzido em conjunto com os professores, e sem considerar as especificidades na relação de cada escola com sua localidade.

Constata-se o desejo, por parte dos professores, de encontrar explicações que melhor satisfaçam seus questionamentos, pois, se possuem um conceito de aluno, há também um de professor, e a este cabe o dever de dar conta da aprendizagem de seus alunos. Não pode haver bons professores e bom ensino, se não houver bom aprendizado. Assim percebem sua responsabilidade. Conforme Rocha, M. (2000), os professores preocupam-se com o fracasso escolar, sentem-se culpados se o sistema desmonta em suas mãos, ou ainda, parecem se despotencializar quando saem de seu lugar de professor tradicional, não se vendo como sujeito capaz de interferir na realidade. Mas, se por um lado ficam aliviados com os especialismos e suas explicações individualizantes ou socializantes, por outro lado, os limites e a ineficácia dos projetos propostos os remetem a investir ou pelo menos desejar novas respostas. Estes questionamentos potencializam linhas que fogem aos padrões de normalidade e normalização e produzem desassossegos.

Considera-se imperativo romper com os processos instituídos e apostar em derivas que estejam a serviço da diferença e de novos processos de subjetivação. É necessário desmontar práticas focalizando os mecanismos que se engendram no cotidiano escolar para, a partir de sua recusa, inventar novas possibilidades de gerir a produção de conhecimentos, construindo alianças com outros saberes.

Como salientam Abramowicz e Levcovitz (2005), produzir diferenças implica estabelecer desafios para as práticas educacionais, posto que delas se exigem reposicionamentos teóricos, e mesmo um desmantelamento do que se produziu como referencial em educação endossado pela cultura, pela ideia de povo, e pelas áreas que a fundamentam, como por exemplo, a Psicologia. Sentir, pensar e agir de forma diferente ao sempre feito requer o rompimento com aquilo que é habitual, a superação de subjetividades estratificadas e a construção de alternativas possíveis, geradoras de novos e diferentes sentidos subjetivos.

Na verdade, como afirma Costa (2007), parece que a própria educação não sabe lidar bem com a diferença, com o imprevisível e o imponderável, que irrompe continuamente na atualidade. Todo projeto educacional homogeneizador teve dificuldade de lidar com a diferença. $\mathrm{O}$ autor assinala que o habitual é pensar a realidade a partir do que já se encontra representado, instituído, territorializado, ou através de categorias negativas, de contradições e 
disjunções do tipo "ou isso, ou aquilo". Assim perseverando, não se consegue entender o virtual, fechando-se às possibilidades de experimentação e invenção. É preciso remover obstáculos históricos, contestar parâmetros únicos e estratificados, "e tomar a desordem como dimensão do real que pode potencialmente gerar novos horizontes ou novas possibilidades de ensino, de aprendizagem e de vida" (COSTA, 2007, p. 20). O pensamento educacional brasileiro não pensa nas diferenças, pensa nas desigualdades.

\section{A Relação Escola-Comunidade}

Iniciou-se esta discussão pelas considerações referentes à importância da escola e expectativas atribuídas à escolarização, trazendo em seguida considerações referentes à participação.

Os moradores foram unânimes em enfatizar a importância da escola e da escolarização dos filhos, pelo conhecimento que estas lhes proporcionam, sobretudo por acreditar que este é um fator considerável para a ascensão ocupacional e melhoria das condições de vida, principalmente no que pode contribuir para o futuro profissional dos filhos.

A escola é instituição reconhecida como responsável pela transmissão do saber universal acumulado pela humanidade e pelo ensino de competências fundamentais, como leitura, cálculo e registro, dentre outras, mas também se inclui nestas competências a possibilidade de uma vivência social diferenciada, introduzindo hábitos e regras necessários ao processo de socialização e ao modo de vida citadino. Isto remete a comunidade à perspectiva de que os conteúdos e práticas escolares possam ajudar seus membros a se tornarem mais hábeis, no enfrentamento das novas situações encontradas nos ambientes urbanos.

$\mathrm{Na}$ interface rural/urbano, a escola é percebida como componente urbano, uma instituição da cidade, que deve preparar o indivíduo para o trabalho na cidade. Parece estar presente a ideia de que é preciso desde cedo formar para a disposição ao trabalho e para isso, um mínimo de conhecimentos deve ser apreendido pelo aluno. Outro aspecto que se evidenciou envolve conhecer pessoas, ou seja, os contatos com agentes ou pessoas importantes que se pode estabelecer na e através da escola, dimensão também considerada relevante para facilitar acessos.

O contato com a escola é, portanto, o contato cotidianamente atualizado, com habilidades a serem acumuladas para uma possível aplicação futura, mesmo que, para a 
maioria desses alunos a escolarização se arraste por muitos anos e tenha no Ensino Fundamental a sua terminalidade, ou mesmo que, para a inserção no mundo do trabalho adulto - que, muitas vezes ocorre paralelamente à escolarização - o conhecimento veiculado acabe não sendo elemento fundamental. O caminho para a superação da situação de pobreza passa pela escola, e a forma apontada por parte dos moradores para esta superação não envolve a transformação do que se efetiva e se produz no campo, mas, sim, a ida para a cidade.

Constatou-se que, também para os agentes institucionais, estas perspectivas são enfatizadas. A rigor, o sistema escolar cuida do que se pode chamar escolarização, uma educação de caráter sistemático e intencional, com ênfase no desenvolvimento cognitivo, em interligação com outros aspectos, como físico, afetivo e social. As falas referem-se ao bom ensino, ao bom ensinante, aos planos estratificados. A escola ensina "o que é importante e necessário para o aluno", e isto envolve o desenvolvimento de habilidades e atitudes, e a aquisição de certo "volume" de conhecimentos e tecnologias que geram a capacitação para o trabalho e para a vida. A democratização da educação básica é considerada via de acesso à cidadania. Enuncia-se a preocupação em atender às demandas dos moradores; todavia, esta definição se desconecta da vida cotidiana, uma vez que o necessário está estabelecido em programas desenvolvidos para as escolas municipais, alheios à vivência local e aos modos de existir.

A ideia de função socializadora, que prepara o aluno para a vida, parece estar associada ao estabelecimento de normas escolares que tendem a refletir as expectativas sociais de formar este sujeito trabalhador, cumpridor de suas obrigações, ordeiro, respeitoso dos direitos dos outros, ético e que, conhecendo seu lugar no mundo, exerce o seu papel de bom grado. (GLÓRIA, 2003)

O que se observa é um discurso reprodutor da visão hegemônica de escola, em que predominam concepções fundamentadas nos moldes liberais, que defendem a educação como direito de todos os cidadãos, e a escola como a que deve propiciar a democratização das oportunidades educacionais e, com isso, prover a formação do cidadão.

Esta concepção de direito à educação é tributária de um modelo educacional que lança suas raízes nas matrizes burguesas. Sob inspiração iluminista, a produção do conhecimento passa a ser monopólio da ciência, principal aliada de um novo modo de produção e acumulação de riqueza, que buscará aprisionar o trabalho e o conhecimento de acordo com as regras da economia política do capital (ALVARENGA; TAVARES, 2008). 
Como herdeira da modernidade, a escola, tal como a conhecemos em seus traços gerais, emergiu como lócus do saber sistematizado, neutro, verdadeiro, necessário à vida em sociedade, e que encaminha o indivíduo ao êxito pessoal. Para Benedetti (2007, p. 109), esta escola nasceu com um horizonte preestabelecido, propondo pela educação a formação do homem: "espera-se que as representações do aluno mudem e que o saber se altere, mas sempre num sentido previamente designado". São saberes indispensáveis à educação e um conjunto de competências a ensinar, com métodos e cartilhas norteando passo a passo como proceder.

Conforme Rocha, S. (2006), a noção de educação repousa sobre o pressuposto metafísico de um sujeito que deve ser educado em função de um fim. Um fim transcendente, cujo valor não reside no processo, mas no objetivo a que deve conduzir: transformar o sujeito em membro, cidadão capaz de se inserir na vida econômica e social; e que se funda na universalidade daquilo que se pretende transmitir.

Concebido neste viés metafísico, o conhecimento elege uma imagem dogmática para representar aquilo que nele não se apresenta (DELEUZE, 1988). Configura-se a busca de uma verdade, uma essência das coisas, aquilo que supostamente elas são. Esta verdade, feita pela ânsia de durabilidade, estabilidade, constância, certeza, estabelece seus critérios naquilo que pretende ser a utilização correta dos códigos, apoiando-se na regulação dos sistemas de conhecimento. Idealizado nos códigos, o conhecimento nega a vida em prol de uma palavra de ordem: o que está certo, o que é bom, o que convém (ZORDAN, 2007).

Nesta perspectiva, a escola também corresponde a um modelo ideal, e consequentemente sempre em falta; uma instância absoluta, universal, calcada no mesmo, na repetição, numa razão unívoca que vai se configurando como eixo que dá consistência a práticas sociais que subtraem o múltiplo, e que a consolidam como um território do sujeito da moral, cujos padrões de normalidade estabelecem as equalizações e previnem contra mudanças que não se constituem dentro da ordem estabelecida (ROCHA, M., 2000). "Normalizações impostas ao indivíduo para fazê-lo mudar de ponto de subjetivação, [...] sempre mais conforme a um suposto ideal” (DELEUZE; GUATTARI, 1995b, p. 84). Uma moral que está afastada das potências de existir e que, ao produzir o sujeito do conhecimento, instaura a produção de um aparelho codificador do desejo. A escola é máquina de ensinar, máquina que captura desejos e fluxos circulantes.

Ainda que apostando numa ontologia da imanência, Benedetti (2007) considera que a educação como um mundo de transcendências e de binarismos, de indivíduos preclassificados em antes, durante e depois da passagem pela escola, se mantém robusta. Predominam 
concepções e expectativas que parecem associadas a uma estrutura molar que impele o sujeito a conduzir-se de acordo com esquemas-padrão.

A recognição, como modelo por excelência da instituição escolar, cumpre uma função especial de acordo com a qual preponderam métodos de assujeitamento de tudo o que possa vir a diferir de uma identidade-padrão, projetada para ocupar o lugar do ideal. Na escola dá-se a entender que a verdade é uma questão de adequação, jamais de produção.O que se delibera nas instâncias educacionais são formas de sujeição, tecnologias de produção de subjetividades em larga escala, afinadas com a instauração de processos de individualização no qual são reforçados padrões universais que serializam e minam as possibilidades criativas das existências. Política educacional para as populações, biopolítica, no sentido foucaultiano (BENEDETTI, 2007, p. 122-3).

A primazia da escola como principal instituição educativa, senão única, e de que os conhecimentos por ela transmitidos são os legítimos, pode também ser analisada como uma estratégia de saber/poder que visa legitimar o conhecimento oficial em detrimento de outros, desqualificando assim outras formas e estilos de vida. A escola tem sido a instituição social central para veicular, de forma homogênea, a cultura considerada "legítima" e para desconsiderar as "não legítimas", ou seja, não-hegemônicas.

Cabe também mencionar que a escola, vista como espaço que ocupa o tempo dos filhos, foi outra característica que emergiu nesta interface, indicando os novos desdobramentos na vivência urbana. Se, para os modos rurais tradicionais, os filhos acompanhavam os pais nas atividades produtivas, quer em casa, na roça ou na pesca, a atual condição de trabalhador assalariado impõe novas exigências, e a ausência dos adultos na rotina diurna de seus filhos. São cada vez mais frequentes as situações em que os filhos ficam em casa sob cuidado do irmão mais velho (também menor de idade), ou sob observação de algum parente ou vizinho, com certo grau de rotatividade. A escola torna-se importante por manter os filhos "longe da rua", o que parece equivaler a mantê-los distantes de possíveis problemas, como más companhias, drogas, violência, e a auxiliar na prescrição dos "bons comportamentos".

Ao assumir o compromisso de atender às demandas dos bons costumes, a escola ratifica discursos preconceituosos e discriminatórios em relação aos povos rurais. Impõe que o que é legítimo vem de fora, e o ambiente em que vivem é representado de forma negativa, como ambiente desprivilegiado, desfavorecido, formas incivilizadas de conhecer a vida e interpretar o mundo (MARTINS, José, 2005). Desconsiderando o ambiente onde a 
comunidade produz sua existência, a escola desarticula as relações entre o homem e seu meio, cristaliza processos, ao mesmo tempo em que facilita a inserção do universo cultural da comunidade no sistema mercantilizante que se estende à região.

Há um conjunto de expectativas que se estende ao aluno rural, que o relaciona à ideia de uma cultura primitiva de povos ignorantes. Esse discurso é vivido de modo ambíguo pelos pais e mesmo por alguns professores, pois a convivência diária com as crianças possibilita certa percepção de seu potencial e de suas realizações, ainda que isto nem sempre se afirme em relação às atividades escolares.

Identificaram-se, nas conversas e relatos formais e informais, as inseguranças e incertezas dos moradores quanto às possibilidades de êxito e de ascensão social de seus filhos, através dos ensinamentos da escola. A escola é parte do movimento de luta por melhorias de suas condições pessoais e coletivas, pela possibilidade de, em parceria, articular conquistas para a comunidade. Muitos pais, que não obtiveram êxito no aprendizado da leitura e da escrita em sua passagem pela escola, na infância, apostam na confiança da capacidade dos filhos, ou pelo menos de alguns, e baseiam-se em suas possibilidades de saúde que lhes permitam trabalhar para conseguir manter os filhos na escola. Mesmo que se explicitem desconfianças na efetividade da escola como mediadora nas atuais exigências impostas pelo mercado de trabalho, os moradores continuam a buscar, via escola, a possibilidade de uma vida melhor.

Pensar na relação escola-comunidade implica se debruçar sobre os fazeres institucionais referentes aos pais; e como um dos temas recorrentes nas agendas atuais encontra-se a participação de pais e moradores na gestão das escolas. Todavia, promover e estimular a participação não é tema livre de dissensos; faz-se necessário saber quais as razões políticas e administrativas por trás deste jargão, a que tipo de participação se refere, o que se engendra neste processo.

O Projeto Temático da escola, ainda que objetive a integração família/escola/comunidade, não faz nenhuma referência à participação dos pais, mas constatamos durante as observações e entrevistas que esta importância é mencionada, destacando-se que as comunidades rurais parecem envolver mais os pais no processo educativo.

Também se apreendeu que algumas estratégias sugeridas estão postas em prática, principalmente no que se refere aos incentivos para que os pais acompanhem a vida escolar. Ainda assim, na maior parte dos casos, a participação da comunidade está relacionada à presença física, em alguns momentos estabelecidos pela direção da escola. Os pais são chamados a reuniões pedagógicas que acabam se tornando meramente administrativas, em 
que são informados sobre os procedimentos e regras a serem cumpridos: tomam ciência do desempenho de seus filhos; ouvem reclamações dos professores em relação à indisciplina, à falta de interesse pelos estudos e ao não cumprimento das tarefas escolares solicitadas, dentre outros.

Os discursos oficializados enfatizam a construção de projetos a partir das necessidades e anseios da comunidade, mas a decisão sobre o que é necessário ou o que selecionar acaba restrita à direção e professores. Fala-se das vantagens de uma gestão participativa na escola, com a criação de conselhos e estruturas que envolvam representantes da comunidade escolar, mas não se assiste à descentralização da administração, nem ao reforço à autonomia dos profissionais ou dos alunos.

Instituído está que os pais participem apenas de certos momentos da escolarização de seus filhos; e aceitar que esta participação caminhe para além do estabelecido parece ser algo difícil e caro aos agentes da escola. Quanto à limitada participação e intervenção dos pais, as justificativas são variadas: desde o argumento de que não estão preparados até o fato de que são analfabetos, ou de que, em algumas situações, ignoram o que é melhor para seus filhos. Se, por um lado, verbaliza-se a importância da participação, por outro, há um discurso que despotencializa a intervenção coletiva e a construção de outros modos de gestão da comunidade e da vida escolar.

A entrada das famílias na atividade escolar é uma das medidas preconizadas pelas reformas educativas dos anos 1990, como estratégia para alterar as regras básicas do sistema educativo (ROSSI, 2001). Alterar, neste contexto, implica recolocar o poder de decisão sobre as práticas de gestão, consideradas em nova distribuição: uma gestão democrática, regulada por dispositivos e decisões coletivas.

O que se observa é que a ideia de comunidade vem sendo esvaziada do sentido de produção coletiva. Como enfatizam Gotardo et al. (2009, p. 3), "remonta a um conglomerado de indivíduos, com desejos a serem decodificados e interpretados, e que devem ser até certo ponto atendidos para que, sub-satisfeito, esse conjunto não rompa com certo funcionamento capitalista. Constata-se um significativo aumento de ações como as consultas à comunidade, mas vemos sérios embaraços quando, por exemplo, irrompe um movimento de pais e/ou de alunos em uma escola”.

Também não dá para falar de gestão coletiva junto às comunidades como se o interesse coletivo, naturalizado, já fosse um bem comum, constituído por valores neutros e consensuais. O exercício de participação é movimento, processual, envolve tensões, pluralidades e singularizações, e pode possibilitar espaços para intervir, reconstruir ou mesmo 
superar o instituído, desestabilizando versões legitimadas pelo poder hegemônico, presente na escola. Sem a participação dos pares na construção do ideário e das ações educacionais, os projetos permanecem como documentos formais a ocupar arquivos, prova do cumprimento de tarefas burocráticas.

Propomos pensar com os institucionalistas, constatando que escola e comunidade não são instâncias em separado, mas se atravessam, se coproduzem, se modificam. Mesmo em face da força do instituído, há relações dinâmicas, interativas e conflitivas que alimentam as experiências instituintes responsáveis por projetar alternativas para a sociedade. A comunidade deve estar presente nas decisões coletivas, para se apropriar afetivamente de seu destino, como algo que também lhe pertence, não sendo mera espectadora, mas produtora de acontecimentos.

Mais do que ensino e reuniões, a escola deve promover encontros. Como diz Benedetti (2007, p.44), "é a vitalidade dos encontros que leva alguém a aprender algo, em algum momento, que lhe desperta a curiosidade para o insuspeitável e atiça o desejo de querer tudo aquilo, uma vez mais". 


\section{TECENDO CONSIDERAÇÕES}

Este estudo propiciou investigar o cotidiano de uma escola rural ribeirinha, enfatizando os atravessamentos presentes nas práticas pedagógicas e a relação escolacomunidade. Procurou-se mergulhar na paisagem educacional no âmbito micropolítico, por meio do visível e do enunciável, isto é, nas composições produzidas na e com a arquitetura, e nos enunciados dos documentos e das manifestações, preocupações e visões em relação à escola e à comunidade. Buscou-se problematizar práticas, evidenciando seus efeitos. Cenas de um universo particular, que dialogam com outros cotidianos.

Utilizaram-se como estratégias de pesquisa a observação participante, a análise documental e entrevistas individuais com professores e moradores, apoiando-se no referencial teórico-metodológico da Análise Institucional, e da Esquizoanálise. Como resultado, apresentou-se uma descrição da comunidade e da escola, procurando-se trazer algumas cenas de seu cotidiano, bem como as concepções e expectativas dos agentes institucionais e de sua clientela sobre a escolarização. Também se chamou atenção para as mudanças que afetam esta comunidade rural, em virtude da acelerada expansão urbana, que promove impactos em seu modo de vida.

Não se tem aqui uma conclusão. Pode-se dizer que este capítulo se interpõe, sobretudo, no âmbito do desejo. Inicialmente, o desejo de transgredir: não concluir, não amarrar, não retomar os objetivos, não parar. Ao mesmo tempo e com força aproximada, o desejo de fechar, e voltar às respostas que paralisam o pensamento. É nesse movimento que a pesquisadora se coloca e se submete às exigências que um trabalho dessa natureza estabelece.

Observou-se, neste estudo, que a escola é vista como agência fundamental na socialização dos alunos, na transmissão de conhecimentos e na reprodução do saber hegemônico; um lugar onde se aprende e nesse aprender, os moradores colocam suas esperanças e perspectivas de mudanças. Ter uma escola na comunidade é muito importante, pois agrega valor social, estreitando relações com as outras comunidades, além de proporcionar segurança e comodidade. Foi possível constatar que a construção da escola deve-se em grande parte, às reivindicações dos moradores por melhorias para a comunidade, incidindo prioritariamente no atendimento ao Ensino Fundamental.

A escola é percebida como um componente urbano necessário para a melhoria das condições de vida, tanto pelos moradores como pelos agentes institucionais. Isto pode ser evidenciado nas práticas e conteúdos disseminados pela escola, e nas falas dos moradores em 
relação à importância da escola na comunidade, que deve preparar para o mercado de trabalho urbano.

Mesmo não atendendo às necessidades de todos os moradores, visto que só oferecia as primeiras séries do Ensino Fundamental, os mesmos consideram-na um primeiro passo no alcance de melhorias. Observou-se que a maioria dos moradores valoriza o trabalho da escola e procura colaborar com as atividades propostas. A direção tem representatividade forte, e é considerada liderança em situações para além da escola.

O cenário comunitário se faz no entrecruzamento rural/urbano, em que os vínculos entre os moradores, os meios de subsistência e a edificação da vida em meio à natureza podem ser considerados como características do ambiente rural. Entretanto, mudanças na comunidade sugerem a desconstrução das formas tradicionais, em detrimento da produção de subjetividades em série, e a escola se coloca como espaço mediador, um dispositivo eficaz na padronização de formas de pensar, perceber, sentir e agir.

A tradição oral anteriormente valorizada na transmissão de conhecimentos tende a ser desconsiderada. Os pais também não se consideram mais responsáveis pela aprendizagem profissional, pois entendem que seus ensinamentos não dão conta de uma nova realidade e se, por um lado, esperam que a escola possa transmitir aos seus filhos a formação necessária para esta inserção, por outro, se ressentem pelas dificuldades em oferecer o suporte necessário para que isto se efetive.

A escola ensina "o que é importante para o aluno" e esse ensinar encontra-se desconectado da vida cotidiana, uma vez que os conteúdos estão estabelecidos num programa desenvolvido para as escolas municipais, alheios à vivência da realidade local. Práticas ruralistas e ribeirinhas não são mencionadas nos projetos ou atividades desenvolvidos pela escola. A referência ao ambiente rural está relacionada à questão ambiental, mas, de modo geral, reproduz concepções descontextualizadas e limitantes, restritas à poluição, ou ainda, considera o mundo rural uma realidade arcaica, a ser superada. Neste sentido, os moradores e seus filhos estão inseridos em um ambiente escolar em que a única ligação estabelecida com as suas vivências parece ser o fato de a escola estar situada na zona rural. Esta escola desconsidera suas crenças, valores e saberes, preparando sujeitos para obedecer e atender a determinadas demandas do mercado. A escola do meio rural é uma escola que estando lá, está fora dali.

Em relação às práticas pedagógicas, a escola ratifica concepções cristalizadas do bom e mau aluno, e das dificuldades de aprendizagem inerentes à criança rural. Também pouco investe em linhas que potencializem a participação do aluno na construção/reconstrução de 
seu conhecimento, a partir de suas experiências e expectativas de aprendizagem, e lhe possibilitem delinear outras formas de pensar e agir. Do modo como se apresenta, a escola rural silencia saberes, e vai emudecendo quem era sábio de histórias, de lendas, de oralidade, de fatos presentes no dia a dia.

Apesar da proposição sóciointeracionista veiculada no discurso oficial estabelecido no Projeto Temático da escola, não se observaram atividades que promovessem a descoberta ou interação, com poucas exceções. O exercício é geralmente construído com base na cópia e na exigência de esforços individuais. Predominam práticas conservadoras, ancoradas em práticas disciplinares, preocupando-se com o controle da atenção, do tempo, do espaço e do corpo. A exigência de bons comportamentos sugere a produção de uma disciplinarização das condutas e internalização do controle, que reforçam as relações de saber/poder. Esta disciplina também se manifesta nos espaços, assemelhados à vigilância pan-óptica.

A participação é tema considerado relevante nas discussões, mas tema que faz temer. Deve ser mantido, em nome da democracia, mas vigiado e sob controle. Embora haja grande estímulo à participação dos pais na vida escolar de seus filhos, esta se restringe aos espaços instituídos e ao acompanhamento das tarefas escolares, despolitizando o próprio conceito de participação.

Visualizou-se uma educação sem potência, povoada de afetos tristes, de perdas, de exclusões. Uma educação que, em geral, esteve afinada com a imagem dogmática, moral e ortodoxa do pensamento, que expulsa "os espíritos que brincam no pátio", subordinando o aprender ao saber. Por outro lado, a insatisfação dos professores com as atuais respostas aos seus questionamentos, a vivacidade dos alunos em suas rotas de fuga e na insistência em comparecer dia após dia, o interesse de pais em colaborar e envolver-se com a escola confirmam o cotidiano como um campo de forças em permanente luta entre processos naturalizados e as forças de invenção, engendradoras de processos instituintes, espaços nem sempre claros, mas sempre presentes, e que indicam que algo acontece, que há uma processualidade em curso (KASTRUP, 2009). Como diz Machado, A. (2007), algo desliza por entre os contornos do instituído, possibilitando frestas e outros agenciamentos.

\section{Implicações educacionais}

Como se afirmou em outros momentos, conhecer é implicar-se; portanto, na tentativa de se colocar como pesquisadora-implicada, pensou-se aqui acerca de alguns movimentos 
que possibilitem habitar o compromisso de permanecer como professora e com os professores rurais nesta caminhada. Não são recomendações, mas pensamentos que foram chegando, ocorrendo e recorrendo durante a elaboração desta tese, inspirados em Deleuze e Guattari, e nos vários interlocutores afinados com e desafinados pela Filosofia da Diferença, que se quer partilhar.

1. Que a educação possa ser pensada como um campo a ser continuamente reinventado, em nossas práticas profissionais e acadêmicas; um processo, um contínuo estar a caminho. Em Educação, não há lugar para a fixidez, para a conclusão, para a última palavra, pois o movimento do cotidiano nos arrasta e nos desafia a permanecer em terra firme. A Educação é, portanto, movimento através do qual nos colocamos em aberto, inacabados, nos projetamos ao diferente. É a mediação possível entre as múltiplas tensões, da constância ao vir a ser.

Para isso, há que se apostar no devir. Os devires são experiências novas, inéditas, que nos colocam em contato com a alteridade do mundo. Um plano de forças que provoca estranhamentos. Há que se apostar no envolvimento e na produção de uma escola menor (GALLO, 2008), e há que se experimentar maneiras novas de se estar no espaço. Uma escola que aprecie a diferença, que não nos torne indiferentes, e tenha cheiros, cores, carnes, ritmos e vibrações. Que incorpore a dissonância e a polifonia, afirmando sempre possibilidades de encontros ainda não experimentados (HECKERT et al., 2001).

2. Convocando Silvio Gallo (2004), minimizar as pretensões massificantes da Pedagogia, para pensar o processo educativo como necessariamente singular e imbuído na produção de subjetividades autônomas, completamente distintas daquela resultante do processo de subjetivação de massa, infundido pelas diferentes pedagogias em exercício. O autor também sugere abandonar a pretensão ao uno, e compreender o real como uma unidade multifacetada, mas ainda assim unidade.

A perspectiva interdisciplinar ressente-se de que na disciplinarização cai-se numa fragmentação. Uma educação rizomática, por sua vez, abre-se para a multiplicidade, para uma realidade fragmentada e múltipla, sem a necessidade mítica de recuperar uma ligação, uma unidade perdida. Os campos de saberes são tomados como absolutamente abertos, com horizontes, mas sem fronteiras, permitindo trânsitos inusitados e insuspeitados (GALLO, 2004, p. 118).

3. A função docente está intimamente ligada à permanente investigação, feita por cada professor sobre suas práticas. Assim, afirmar com os agentes da cena institucional-escolar a 
possibilidade de refletir sobre a ação pedagógica, e tentar apreender, junto com as pessoas interessadas, numa série variada de problemas, os limites que as transformações e/ou cristalizações históricas nos tem imposto, a fim de engendrar possibilidades de transgredi-las. Criar práticas, acontecimentos que permitam movimentar aquilo que está cristalizado, produzindo diferenciações. Como salienta Machado, A. (2003), derivar, apostando em uma deriva que esteja a serviço dos processos de subjetivação, e não de assujeitamento.

4. Reforça-se a ideia de que o planejamento pedagógico deve se referir a um projeto geral de investigação, construído no coletivo, dado que diz respeito a todas as forças que constituem a prática pedagógica, e se fazem presentes nos múltiplos atravessamentos na organização escolar. Aqui se convoca Guattari (1992), para ressaltar a importância de conduzir, simultaneamente, modos de atividades que favoreçam uma tomada de responsabilidade coletiva, fundada, entretanto, numa ressingularização da relação com o trabalho e, mais geralmente, da existência pessoal.

5. Imprescindível a condução de políticas que assegurem aos povos tradicionais o atendimento a suas demandas. As escolas ribeirinhas são comumente tratadas sob o discurso generalizado da educação rural, invocando uma unicidade que passa ao largo das suas especificidades, ocultando modos peculiares da escolarização vivenciada ao longo da hiléia amazônica. O insucesso das políticas públicas também está na não observância da heterogeneidade do ambiente, em sua capacidade de resposta.

6. A aprendizagem é processo de invenção de si e do mundo (KASTRUP, 2008), inclui a experiência de produção de um aprendizado que só surge com o aprender. Há que propor o pensar e não apenas o conhecer. Pensar no sentido de problematizar, desconstruir, afetar-se. Potencializar o espaço da dúvida e o lugar do não-saber.

7. O professor pode surpreender seus alunos, mostrando que, mesmo na escola, há coisas imprevisíveis e interessantes. Vale perder gradativamente o controle do processo, passando progressivamente de coordenador a assessor, na medida em que o aluno assume uma postura de agente que empreende o saber.

8. Também cabe (per)seguir as pistas que vão surgindo, atentos a capturar um sorriso, um gesto ou um olhar interessado numa figura de livro ou revista qualquer, e por aí encontrar a 
chave para portas irremediavelmente trancadas. Para além do "olhar" do professor "sobre" o aluno, "sobre" suas dificuldades, a diferença entre o "querer" e o "não querer" do aluno pode estar nesse "ir ao encontro".

Que se faça da escola pública um grande lugar, pois este, segundo Guattari (1992), é reservado à inovação, à improvisação de atividades novas.

A pesquisadora se sente, assim, inclinada a retornar para as experiências em escolas e comunidades ribeirinhas, a fim de escavar os movimentos e trilhar a abertura aos devires que atravessam os agenciamentos. 


\section{REFERÊNCIAS BIBLIOGRÁFICAS}

AB'SABER, A. Problemas da Amazônia brasileira. Estudos Avançados, São Paulo, v. 19, n. 53, p. 7-35, 2005.

ABRAMOWICZ, A.; LEVCOVITZ, D. Tal infância, qual criança? Em: ABRAMOWICZ, A. SILVÉRIO, V. R. (Orgs.) Afirmando diferenças: montando o quebra-cabeça da diversidade na escola. Campinas, SP: Papirus, 2005. p. 73-86.

ADAMS, C.; MURRIETA, R.; NEVES, W. (Ed.) Sociedades caboclas amazônicas: modernidade e invisibilidade. São Paulo: Annablume, 2006.

AGUIAR, K. F.; ROCHA, M. L. Micropolítica e o exercício da pesquisa-intervenção: referenciais e dispositivos em análise. Psicologia: Ciência e profissão, Brasília, v.27, n.4, p.648-663, dez. 2007.

ALMEIDA, A. W. B. Amazônia: a dimensão política dos conhecimentos tradicionais. Em: Antropologia dos Archivos da Amazônia. Rio de Janeiro: Casa 8/ Fundação Universidade do Amazonas, 2008. p. 127-154.

Terras de quilombo, terras indígenas, babaçus livres, castanhais do povo, faxinais e fundos de pasto: terras tradicionalmente ocupadas. Manaus: PPGSCA-UFAM, 2006.

. A dimensão política dos conhecimentos tradicionais na Amazônia. CEAS, Salvador, n. 216, p. 9-30, mar./abr. 2005.

ALVARENGA, M. S.; TAVARES, M. T. G. Cotidiano escolar e as redes de conhecimento na escola: notas sobre processos de escolarização de crianças de periferias urbanas. Em: FERRAÇO, C. E.; PEREZ, C. L. V.; OLIVEIRA, I. B. (Orgs.) Aprendizagens cotidianas com a pesquisa: novas reflexões em pesquisa nos/dos/com os cotidianos das escolas. Petrópolis, RJ: DP et Alii, 2008. Coleção Vida Cotidiana e Pesquisa em Educação. p. 149158.

ALVARES, J.; PASSOS, E. Cartografar é habitar um território existencial. Em: PASSOS, E.; KASTRUP, V.; ESCÓSSIA, L. Pistas do método da cartografia: pesquisa-intervenção e produção de subjetividade. Porto Alegre: Sulina, 2009. p.131-149.

ALVES, N. Decifrando o pergaminho: os cotidianos das escolas nas lógicas das redes cotidianas. Em: OLIVEIRA, I. B.; ALVES, N. (Orgs.) Pesquisa nos/dos/com os cotidianos das escolas. Petrópolis, RJ: DP et Alii, 2008. p. 15-38 
ALVES, N. Sobre movimentos das pesquisas nos/dos/com os cotidianos. Teias, Rio de Janeiro, v. 4, n.7-8, p.1-8, jan./dez. 2003.

ANDRADE, A. S. O cotidiano de uma escola pública de $1^{\circ}$ grau: um estudo etnográfico. Cadernos de pesquisa, São Paulo n.73, p. 26-37, maio 1990.

ANDRÉ, M. E.D.A. Etnografia da prática escolar. Campinas/SP: Papirus, 1995.

A pesquisa no cotidiano escolar. Em: FAZENDA, I. Metodologia da pesquisa educacional. 5. ed. São Paulo: Cortez, 1989.

AZAMBUJA, M. A.; GUARESCHI, N. M. F. Devir vírus. Revista do Departamento de Psicologia - UFF, Niterói/RJ, v.19, n.2, p. 423-438, jul./dez. 2007.

AZANHA, J. M. P. Uma idéia de pesquisa educacional. São Paulo: Edusp/Fapesp, 1992.

BARDIN, L. Análise de conteúdo. Tradução de Luiz Antonio Reto e Augusto Pinheiro. Lisboa: Edições 70, 1977.

BARRETO FILHO, H. T. Populações tradicionais: introdução à crítica da ecologia política de uma noção. Em: ADAMS, C.; MURRIETA, R.; NEVES, W. (Ed.) Sociedades caboclas amazônicas: modernidade e invisibilidade. São Paulo: Annablume, 2006. p. 109-144.

BATISTA, D. O espaço e a humanidade. Em: O complexo da Amazônia: análise do processo de desenvolvimento. Rio de Janeiro: Conquista 1976. p. 31-98.

BAUER, M. W.; GASKELL, G. (Orgs.) Pesquisa qualitativa com texto, imagem e som: um manual prático. Tradução de Pedrinho Guareschi. 3. ed. Petrópolis/RJ: Vozes, 2002.

BECKER, B. Geopolítica da Amazônia. Em: Estudos Avançados, São Paulo, v. 19 n. 53, p. 71-86, 2005.

BENEDETTI, S. C. G. Entre a educação e o plano de pensamento de Deleuze \& Guattari: uma vida... 2007. 178 p. Tese (Doutorado em Educação) - Faculdade de Educação, Universidade de São Paulo, São Paulo, 2007. Disponível em: <http://www.teses.usp.br/teses/ disponiveis/48/48134/tde-26062007-090606/>. Acesso em: 27 abr. 2010.

BENFICA, W. A. A escola rural na década de 90: expectativas e significados da experiência escolar para os alunos e suas famílias. 2006. 160f. Dissertação (Mestrado em Educação) - Faculdade de Educação, Pontifícia Universidade Católica de Minas Gerais, Belo Horizonte, 2006. 
BOGDAN, R.; BIKLEN, S. Investigação qualitativa em educação: uma introdução à teoria e aos métodos. Tradução de Maria João Alves, Sara B. dos Santos e Telmo M. Batista. Porto/Portugal: Ed. Porto, 1994.

BRANCALEONI, A. P. Um olhar acerca do processo de elaboração e implementação de um projeto político-pedagógico em uma escola do campo no município de Araraquara. 2005. 198 p. Tese (Doutorado em Educação) - Faculdade de Filosofia, Ciências e Letras, Universidade de São Paulo, Ribeirão Preto/SP, 2005.

BRASIL. Decreto $\mathrm{n}^{0}$ 6.040, de 07 de fevereiro de 2007. Institui a Política Nacional de Desenvolvimento Sustentável dos Povos e Comunidades Tradicionais - PNPCT. Diário Oficial da República Federativa do Brasil, Brasília, DF, 08 fev. 2007. Disponível em <http://www.planalto.gov.br/ccivil_03/_Ato2007_2010/2007/Decreto/D6040.htm>. Acesso em: 22 maio 2008.

BRASIL. Lei $\mathrm{n}^{0}$ 9.394, de 20 de dezembro de 1996. Estabelece as Diretrizes e Bases da Educação Nacional. Diário Oficial da República Federativa do Brasil, Brasília, DF, 23 dez. 1996. Disponível em <http://www.mec.gov.br/legis/pdf/LDB.pdf>. Acesso em: 22 maio 2008.

CALAZANS, M. J. Para compreender a educação do Estado no meio rural - Traços de uma trajetória. Em: THERRIEN, J.; DAMASCENO, M N. (Orgs.) Educação e Escola no Campo. Campinas, SP: Papirus, 1993. p. 15-42.

CARVALHO, J. M. Cartografia e cotidiano escolar. Em: FERRAÇO, C. E.; PEREZ, C. L. V.; OLIVEIRA, I. B. (Orgs.) Aprendizagens cotidianas com a pesquisa: novas reflexões em pesquisa nos/dos/com os cotidianos das escolas. Petrópolis, RJ: DP et Alii, 2008. Coleção Vida Cotidiana e Pesquisa em Educação. p. 121-136.

CATHARINO, T. R. Psicologia na educação: contribuições da análise institucional para o processo pedagógico. Em: GARCIA, R. L.; ALVES, N. (Orgs.) O sentido da escola. Petrópolis, RJ: DP\&A, 2000. p. 38-48.

CERTEAU, M. A invenção do cotidiano: 1. Artes de fazer. 15. ed. Tradução de Ephraim Ferreira Alves. Petrópolis, RJ: Vozes, 2008.

CHAVES, M. P. S. R. Estudo das condições de vida e das formas de uso dos recursos nas sedes e comunidades ribeirinhas de Coari e Carauari-AM. Manaus: UFAM, 2004.

Processo sócio-educativo de organização comunitária para cidadania nas comunidades ribeirinhas do município de Maués/AM. Manaus: UFAM/Interação, 2002. 27 p. Relatório técnico. 
CHAVES, M. S. R.; SILVA, E. C. L. A dinâmica das relações comunitárias no Parque Nacional do Jaú: as relações de ajuda mútua nas atividades coletivas. Ciências Humanas, Manaus, v.9, n.1/2, p. 42-57, jan./dez.2003.

COELHO, R. F. Ribeirinhos Urbanos: Modos de Vida e Representações Sociais dos Moradores do Puraquequara. 2007. 168 p. Dissertação (Mestrado em Sociedade e Cultura na Amazônia) - Instituto de Ciências Humanas e Letras, Universidade Federal do Amazonas, Manaus, 2007.

COIMBRA, C. M. B. Guardiães da ordem: uma viagem pelas práticas psi no Brasil do "milagre". Rio de Janeiro: Oficina do autor, 1995.

COIMBRA, C. M. B.; LEITÃO, M. B. Das essências às multiplicidades: especialismo psi e produções de subjetividades. Psicologia \& Sociedade, Florianópolis, v. 15, n. 2, p. 6-17, jul./dez. 2003.

CÔRTES, A. S. B. O panóptico de Yone: astúcias e táticas contra o poder disciplinar nos espaços de controle da escola. 2004. 294 f. Dissertação (Mestrado em Educação) - Faculdade de Educação, Universidade Federal Fluminense, Niterói/RJ, 2004.

COSTA, S. S. G. Educação, políticas de subjetivação e sociedades de controle. Em: MACHADO, A. M.; FERNANDES, A. M. D.; ROCHA, M. L. (Orgs.). Novos possíveis no encontro da psicologia com a educação. São Paulo: Casa do Psicólogo®, 2007. p. 15-36.

CRUZ, M. J. M. Territorialização camponesa na várzea da Amazônia. 2007. 261 p. Tese (Doutorado em Geografia Humana) - Faculdade de Filosofia, Letras e Ciências Humanas, Universidade de São Paulo, São Paulo, 2007.

DAMASCENO, M. N.; BESERRA, B. Estudos sobre educação rural no Brasil: estado da arte e perspectivas. Educação e Pesquisa, São Paulo, v.30, n.1, p. 73-89, jan./abr. 2004.

DANIEL, J. Tesouro descoberto no Rio Amazonas. Rio de Janeiro: Biblioteca Nacional, 1976.

DELEUZE, G. Foucault. Tradução de Claudia Martins. São Paulo: Brasiliense, 2006a.

Lógica do sentido. 4. ed. 2. reimpressão. Tradução de Luiz Roberto Salinas Fortes. São Paulo: Perspectiva, 2006b.

Desejo e prazer. 1994. Disponível em <http://www.unb.br/fe/tef/filoesco/ foucault/art07.html>. Acesso em: 13 set. 2009. 
DELEUZE, G. Conversações. Tradução de Peter Pál Pelbart. São Paulo: Editora 34, 1992.

Diferença e repetição. Tradução de Luiz Orlandi e Roberto Machado. Rio de Janeiro: Graal Editora, 1988.

DELEUZE, G.; GUATTARI, F. Kafka por uma literatura menor. Tradução de Rafael Godinho. Lisboa: Assírio \& Alvim, 2003.

Mil platôs: capitalismo e esquizofrenia. Tradução de Aurélio Guerra Neto e Célia P. Costa. São Paulo: Editora 34, 1995a. v. 1.

Mil platôs: capitalismo e esquizofrenia. Tradução de Ana Lúcia de Oliveira e Lúcia Cláudia Leão. São Paulo: Editora 34, 1995b. v. 2.

Mil platôs: capitalismo e esquizofrenia. Tradução de Suely Rolnik. São Paulo: Editora 34, 1997. v. 4.

O que é a filosofia? Tradução de Bento Prado Jr. e Alberto Alonso Muñoz. São Paulo: Editora 34, 1992.

O anti-Édipo: capitalismo e esquizofrenia. Tradução de Georges Lamazière. Rio de Janeiro: Imago, 1976.

DELEUZE, G.; PARNET, C. Diálogos. Tradução de José Gabriel Cunha. Lisboa: Relógio D’Água Editores, 2004.

DIEGUES, A. C. O mito moderno da natureza intocada. São Paulo: Hucitec, 1996.

2005.

( (Org.) Desmatamento e modos de vida na Amazônia. São Paulo: NUPAUB/ USP,

DIEGUES, A. C.; NOGARA, P. J. O nosso lugar virou parque: estudo sócio-ambiental do Saco do Mamanguá-Parati-Rio de Janeiro. São Paulo: NUPAUB/USP, 1994.

EZPELETA, J.; ROCKWELL, E. Pesquisa participante. Tradução de Francisco Salatiel de Alencar Barbosa. São Paulo: Cortez/Autores Associados, 1986.

FARIA FILHO, L. M.; GONÇALVES, I. A.; VIDAL, D. G. PAULILO, A. L. A cultura escolar como categoria de análise e como campo de investigação na história da educação brasileira. Educação e pesquisa. São Paulo, v. 30, n.1, p.139-159, jan./abr. 2004. 
FERNANDES, A. et al. Histórias e práticas do sofrer na escola: múltiplos atos/atores na produção do "aluno-problema". Em: MACHADO, A. M.; FERNANDES, A. M. D.; ROCHA, M. L. (Orgs.). Novos possíveis no encontro da psicologia com a educação. São Paulo: Casa do Psicólogo®, 2007. p. 145-166.

FERNANDES, A. M. D.; ROZENOWICZ, A.; FERREIRA, J. Avaliação qualitativa e a construção de indicadores sociais: caminhos de uma pesquisa/intervenção em um projeto educacional. Psicologia em estudo, Maringá, v.9, n.2, p.243-253, maio/ago. 2004.

FERRAÇO, C. E. Eu, caçador de mim. Em: GARCIA, R. L. (Org.) Método: pesquisa com o cotidiano. Rio de Janeiro: DP\&A, 2003. p. 157-212.

FERRAÇO, C. E. A pesquisa em educação no/do/com o cotidiano das escolas. Em: FERRAÇO, C. E.; PEREZ, C. L. V.; OLIVEIRA, I. B. (Orgs.) Aprendizagens cotidianas com a pesquisa: novas reflexões em pesquisa nos/dos/com os cotidianos das escolas. Petrópolis, RJ: DP et Alii, 2008. Coleção Vida Cotidiana e Pesquisa em Educação. P. 23-34.

FERRAZ, L. Ambiente e participação social: estudo de caso sobre a Vila do Puraquequara. 1999. 129 f. Dissertação (Mestrado em Ciências do Ambiente e Sustentabilidade da Amazônia) - Centro de Ciências do Ambiente, Universidade Federal do Amazonas, Manaus, 1999.

FERREIRA, A. R. Viagem filosófica ao Rio Negro. Belém: Museu Paraense Emílio Goeldi, 1972.

FOUCAULT, M. Microfísica do poder. 6. ed. Organização e tradução de Roberto Machado. Rio de Janeiro: Graal, 1986.

Vigiar e punir: nascimento da prisão. 6. ed. Tradução de Lígia M. Ponde Vassalo. Petrópolis, RJ: Vozes, 1988.

FRAXE, T. J. P. Cultura cabocla-ribeirinha: mitos, lendas e transculturalidade. São Paulo: Annablume, 2004.

Homens-anfíbios: etnografia de um campesinato das águas. São Paulo: Annablume; Fortaleza: Secretaria da Cultura e Desporto do Governo do Estado do Ceará, 2000.

FREITAS, M. N. M. O ensino de ciências em escolas multisseriadas na Amazônia ribeirinha: um estudo de caso no Estado do Pará. 2005. 113 f. Dissertação (Mestrado em Educação em Ciências e Matemática) - Núcleo Pedagógico de Apoio ao Desenvolvimento Científico, Universidade Federal do Pará, Belém, 2005. 
GALDINI, V.; AGUIAR, W. M. J. Intervenção junto a professores da rede pública: potencializando a produção de novos sentidos. Em: MEIRA, M. E. M.; ANTUNES, M. A. M. (Orgs.) Psicologia escolar: práticas críticas. São Paulo: Casa do psicólogo, 2003. p. 87-104.

GALLO, S. Deleuze \& a educação. 2. ed. Belo Horizonte: Autêntica, 2008.

Transversalidade e formação de professores. Em: RIVERO, Cléia M. L. GALLO, S. (Orgs.) A formação de professores na sociedade do conhecimento. Bauru, SP: Edusc, 2004. p. 101-121.

GALVÃO, I. Cenas do cotidiano escolar: conflito sim, violência não. 2. ed. Petrópolis, RJ: Vozes, 2008.

GARCIA, R. L. Tentando compreender a complexidade do cotidiano. Em: (Org.)

Método: pesquisa com o cotidiano. Rio de Janeiro: DP\&A, 2003. p. 9-16.

GLORIA, D. M. A. A escola dos que passam sem saber: a prática da não-retenção escolar na narrativa de alunos e familiares. Revista Brasileira de Educação, Rio de Janeiro, n. 22, 2003. Disponível em: <http://www.scielo.br/scielo.php?script=sci_arttext\&pid=S141324782003000100007\&lng=en\&nrm=iso>. Acesso em: 28 mar. 2008.

GOTARDO, S. M. et al. Pensando a relação escola-comunidade como exercício de produção do comum. Em: ENCONTRO NACIONAL DA ABRAPSO, 15, 2009, São Paulo. Anais eletrônicos... São Paulo: ABRAPSO, 2009. Disponível em: <http://www.abrapso.org. br/siteprincipal/images/Anais_XVENABRAPSO/67.\%20pensando\%20a\%20rela\%C7\%C3o\% 20escola-comunidade $\% 20$ como $\% 20$ exerc $\%$ CDcio $\% 20$ de\%20produ\%C7\%C3o\%20do\%20comum.pdf>. Acesso em: 03 abr. 2010

GRISCI, C. L. I. Tempos modernos, tempos mutantes: produção de subjetividade na reestruturação do trabalho. Psicologia \& Sociedade, Porto Alegre, v. 13 n. 1, p. 75-92, jan./jun. 2001.

GUATTARI, F. As três ecologias. Tradução de Maria Cristina F. Bittencourt. 17. ed. São Paulo: Papirus, 2006.

Práticas analíticas e práticas sociais. Em: Caosmose: um novo paradigma estético. Tradução de Ana Lúcia de Oliveira e Lúcia Cláudia Leão. Rio de Janeiro: 34 letras, 1992. p. 183-203.

Revolução molecular: pulsações políticas do desejo. 3. ed. São Paulo: Brasiliense, 1987. p. 34-44. 
GUATTARI, F. ROLNIK, S. Micropolítica: cartografias do desejo Petrópolis, RJ: Vozes, 1986. cap. II. Subjetividade e história, p. 25-61.

GUIRADO, M. A análise institucional de Georges Lapassade. Em:

institucional. São Paulo: EPU, 1997. (Coleção temas básicos de psicologia, 15). Psicologia

HAGE, S. M. Educação do campo na Amazônia: retratos da realidade das escolas multisseriadas no estado do Pará. Em: Reunião Anual da SBPC, 57, 2005, Fortaleza. Anais eletrônicos... Fortaleza: UFC, 2005. Disponível em <http://www.educampoparaense.org>. Acesso em: 23 jul. 2008.

HARRIS, M. Presente ambivalente: uma maneira amazônica de estar no tempo. Em: ADAMS, C.; MURRIETA.; R. NEVES, W. (Ed.) Sociedades caboclas amazônicas: modernidade e invisibilidade. São Paulo: Annablume, 2006. p. 81-108.

HASHIZUME, C. M.; LOPES, M. M. Trabalho docente rural: dores e prazeres do ofício. Estudos e Pesquisa em Psicologia, Rio de Janeiro, v. 6, n. 1, p. 99-108, jan./jun. 2006.

HECKERT, A. L. C. et al. A escola como espaço de invenção. Em: JACÓ-VILELA, A.; CEREZZO, A.; RODRIGUES, H. Clio-Psyché hoje: Fazeres e dizeres psi na história do Brasil. Rio de Janeiro: Relume Dumará, 2001. p. 239-250.

HECKERT, A. L. C.; BARROS, M. E. B. Desafios metodológicos para a pesquisa no campo da psicologia: o que pode uma pesquisa? Em: MACHADO, A. M.; FERNANDES, A. M. D.; ROCHA, M. L. (Orgs.). Novos possíveis no encontro da psicologia com a educação. São Paulo: Casa do Psicólogo®, 2007. p. 86-116.

IBGE. Censo demográfico 2000. Disponível em <http://www.ibge.gov.br/home/ estistica/populacao/default_censo_2000.shtm>. Acesso em: 12 jan. 2009.

Contagem da população 2007 - agregado por bairros. Rio de Janeiro: IBGE, 2008. 25 p.

JESUS, C. P. Utopia cabocla amazonense: agricultura familiar em busca da economia solidária. Canoas/RS: Editora da ULBRA, 2000.

KASTRUP, V. O funcionamento da atenção no trabalho do cartógrafo. Em: PASSOS, E.; KASTRUP, V.; ESCÓSSIA, L. (Orgs.) Pistas do método da cartografia: pesquisaintervenção e produção de subjetividade. Porto Alegre: Sulina, 2009. p.32-51.

KASTRUP, V. A aprendizagem da atenção na cognição inventiva. Psicologia e Sociedade, Porto Alegre, v. 16, n. 3, set./dez. 2004. Disponível em: <http://www.scielo.br/ scielo.php?script=sci_arttext\&pid=S0102-71822004000300002\& lng=en\&nrm=iso >. Acesso em: 13 abr. 2009. 
KASTRUP, V. O Devir-criança e a cognição contemporânea. Psicologia Reflexão e Crítica, Porto Alegre, v.13, n.3, p. 373-382, 2008.

L'ABBATE, S. A análise institucional e a saúde coletiva. Ciência \& Saúde Coletiva, Rio de Janeiro, vol.8, n.1, p.265-274, 2003.

LAPASSADE, G. As microssociologias. Tradução de Lucie Didio. Brasília: Líber Livro Editora, 2005.

Grupos, organizações e instituições. Tradução de Henrique Augusto de Araújo Mesquita. Rio de Janeiro: Francisco Alves, 1983.

LEITE, S. C. Escola rural: urbanização e políticas educacionais. São Paulo: Cortez, 2002.

LINHARES, C. Experiências instituintes em escolas públicas: memórias e projetos para formação de professores. Rio de Janeiro: CNPq/UFF, 2002.

LOURAU, R. Objeto e método da análise institucional. Em: ALTOÉ, S. (Org.) René Lourau: analista institucional em tempo integral. São Paulo: Hucitec, 2004a. p. 66-86.

O instituinte contra o instituído. Em: ALTOÉ, S. (Org.) René Lourau: analista institucional em tempo integral. São Paulo: Hucitec, 2004b. p. 47-65.

Implicação: um novo paradigma. Em: ALTOÉ, S. (Org.) René Lourau: analista institucional em tempo integral. São Paulo: Hucitec, 2004c. p. 143-158.

Análise institucional e práticas de pesquisa. René Lourau na UERJ. Rio de Janeiro: UERJ, 1993.

Sociólogo em tempo inteiro: análise institucional e pedagogia. Lisboa: Editorial Estampa, 1979.

MACHADO, A. M. Plantão institucional: um dispositivo criador. Em: MACHADO, A. M.; FERNANDES, A. M. D.; ROCHA, M. L. (Orgs.). Novos possíveis no encontro da psicologia com a educação. São Paulo: Casa do Psicólogo®, 2007. p. 116-144.

Articulação da saúde com a educação nos desafios da educação inclusiva. Em: MACHADO, A. M. et al. Psicologia e direitos humanos: educação inclusiva, direitos humanos na escola. São Paulo: Casa do Psicólogo; Brasília, DF: Conselho Federal de Psicologia, 2005. p. 71-82. 
MACHADO, A. M. Os psicólogos trabalhando com a escola: intervenção a serviço de quê? Em: MEIRA, M. E. M.; ANTUNES, M. A. M. (Orgs.) Psicologia Escolar: práticas críticas. São Paulo: Casa do psicólogo, 2003. p. 11-32.

MACHADO, R. Deleuze, a arte e a filosofia. Rio de Janeiro: Jorge Zahar ed., 2009.

MADEIRA, M. C. Como e para quem a escola se diz. Revista de Educação AEC, Brasília, a. 35, n. 141 , p. 40-48, out./dez. 2006.

MAIA, M. A. B. O corpo invisível no trabalho: cartografia dos processos de trabalho em saúde. 2006. 196 f. Dissertação (Mestrado em Psicologia) - Instituto de Ciências Humanas e Filosofia, Universidade Federal Fluminense, Niterói/RJ, 2006.

MARTINS, João B. A atuação do psicólogo escolar: multirreferencialidade, implicação e escuta clínica. Psicologia em Estudo, Maringá, v. 8, n. 2, p. 39-45, jul./dez. 2003,

MARTINS, José S. Educação rural e o desenraizamento do educador. Revista Espaço acadêmico, Maringá, n. 49, jun. 2005. Disponível em <http://www.espacoacademico. com.br/049/49cmartins.htm>. Acesso em: 15 ago. 2009.

MATTOS, C. L. G. Abordagem etnográfica na pesquisa imagens da exclusão. Sementes: cadernos de pesquisa, Salvador, v.5, n.7, p. 66-81, jan./dez. 2004.

MEDEIROS, M. G. F. Um estranho no espelho: Representações do caboclo amazônico. 2004. 188 f. Dissertação (Mestrado em Sociedade e Cultura na Amazônia) - Instituto de Ciências Humanas e Letras, Universidade Federal do Amazonas, Manaus, 2004.

MINAYO, M. C. S. O Desafio do Conhecimento: pesquisa qualitativa em saúde. 4. ed. São Paulo: Hucitec-Abrasco. 1996.

MISKOLCI, R. Um corpo estranho na sala de aula. Em: ABRAMOWICZ, A. SILVÉRIO, V. R. (Orgs.) Afirmando diferenças: montando o quebra-cabeça da diversidade na escola. Campinas, SP: Papirus, 2005. p. 13-26.

MORAES, R. O homem do Pacoval. Manaus: Governo do Estado do Amazonas, 1936.

MORÁN, E. F. A ecologia humana das populações da Amazônia. Petrópolis, RJ: Vozes, 1990.

MOREIRA, H. L. F. Marudá: aspectos da mudança social em uma comunidade de pescadores da Amazônia. Em: FURTADO, L.; LEITÃO, W.; MELlO, A. F. (Orgs). Povos das águas: realidade e perspectivas na Amazônia. Belém: Museu Paraense Emílio Goeldi, 1993. 
MOYSÉS, M. A. A. A institucionalização invisível: crianças que não aprendem na escola. Campinas: Mercado das Letras; São Paulo: Fapesp, 2001.

MUYLAERT, M. A. AT como dispositivo clínico: uma perspectiva da esquizoanálise. Psychê, São Paulo, a. 10, n. 18, p. 109-114, set. 2006.

OLIVEIRA, I. B.; ALVES, N. (Orgs.). Pesquisa nos/dos/com os cotidianos das escolas: sobre redes de saberes. Petrópolis, RJ: DP et Alii, 2008. Coleção Vida Cotidiana e Pesquisa em Educação.

OLIVEIRA, I. B. Currículos praticados, emancipação social e democracia no cotidiano da escola: um relato de pesquisa. Em: FERRAÇO, C. E.; PEREZ, C. L. V.; OLIVEIRA, I. B. (Orgs.) Aprendizagens cotidianas com a pesquisa: novas reflexões em pesquisa nos/dos/com os cotidianos das escolas. Petrópolis: DP et Alii, 2008. Coleção Vida Cotidiana e Pesquisa em Educação. P. 105-120.

OLIVEIRA, J. A. A vivência nas cidades da Amazônia: algumas reflexões. CEAS, Salvador, n. 207, p. 55-65, set./out. 2003.

OLIVEIRA, J. A. Repensando o estudo das pequenas cidades amazônicas. Ciências Humanas, Manaus, v.4, n. 1-2, p. 155-175, 2000.

OLIVEIRA, L. M. S. R. Educação rural e desenvolvimento local sustentável: a lógica subjacente das relações inter-setoriais. 2005. 297 f. Tese (Doutorado em Desenvolvimento Sustentável do Trópico Úmido) - Núcleo de Altos Estudos Amazônicos, Universidade Federal do Pará, Belém, 2005.

OLIVEIRA, M. M. Migração na cidade de Manaus: algumas análises preliminares. Em: CEAS, Salvador, n. 216, p. 95-119, mar./abr. 2005.

OLIVEIRA JR., P. H. Ribeirinhos e roceiros: gênese, subordinação e resistência camponesa em Gurupá/PA. 1991. Dissertação (Mestrado em Geografia Humana) - Faculdade de Filosofia, Letras e Ciências Humanas, Universidade de São Paulo, São Paulo, 1991.

OLIVEIRA, R. M. Tecnologia e subjetivação: a questão da agência. Psicologia \& Sociedade, Porto Alegre, v. 17, n. 1, p. 56-60, jan./abr. 2005.

PAIM, I. M. As novas faces da desigualdade no cotidiano escolar. 2003. 335 p. Tese (Doutorado em Educação) - Faculdade de Educação, Universidade Federal Fluminense, Niterói/RJ, 2003. 
PARPINELLI, R. S.; SOUZA, E. W. F. Pensando os fenômenos psicológicos: um ensaio esquizoanalítico. Psicologia e Estudo, Maringá, v. 10, n. 3, p. 479-487, set./dez. 2005. Disponível em: <http://www.scielo.br/scielo.php?script=sci_arttext\&pid =S1413-73722005 000300016\&lng=es\&nrm=iso>. Acesso em: 29 Abr. 2008.

PATTO, M.H. S. A produção do fracasso escola: histórias de submissão e rebeldia. São Paulo: T. A. Queiroz, 1990.

PEREIRA, Hamida A. Fronteiras da vida: o tradicional e o moderno no Cacau Pirêra/Iranduba. 2006. 192 p. Dissertação (Mestrado em Sociedade e cultura na Amazônia) Instituto de Ciências Humanas e Letras, Universidade Federal do Amazonas, Manaus, 2006.

PEREIRA, Henrique. S. Gestão participativa e o movimento de preservação de lagos no Amazonas. Em: CEAS, Salvador, n. 207, p.67-89, set./out. 2003.

PÉREZ, C. L. V. A lógica e o sentido da formação: heterotopias, acontecimentos e sujeitos. Revista do Departamento de Psicologia - UFF, Niterói, v. 19, n. 1, p. 127-144, jan./jun. 2007.

PORTO, M. R. Escola rural: cultura e imaginação. 1994. 210 p. Tese (Doutorado em Educação) - Faculdade de Educação, Universidade de São Paulo, São Paulo, 1994.

REIS NETO, A. Escola rural: o caminho da cidade. O caso do município de Floriano - PI. 2005. 109 p. Dissertação (Mestrado em Educação) - Faculdade de Educação, universidade Federal do Ceará, Fortaleza, 2005. Disponível em <http://www.bdae.org.br/dspace/ handle/123456789/1619>. Acesso em: 29 maio 2008.

RIBEIRO, M. Educação básica do campo: um desafio aos trabalhadores da terra. Disponível em: <http://www.ufrgs.br/tramse/perural/artigos/educacaodocampo.rtf>. Acesso em: 15 ago. 2009.

ROCHA, M. L. A formação como acontecimento: solidão, pensamento e autogestão. Em: MACHADO, A. M.; FERNANDES, A. M. D.; ROCHA, M. L. (Orgs.). Novos possíveis no encontro da psicologia com a educação. São Paulo: Casa do Psicólogo®, 2007. p. 37-48.

. Psicologia e as práticas institucionais: a pesquisa-intervenção em movimento. Psico, Porto Alegre, v.37, n.2, p.169-174, maio/ago. 2006a.

Identidade e diferença em movimento: ressonâncias da obra de Deleuze. Revista do Departamento de Psicologia - UFF, Niterói, v. 18, n. 2, p. 57-68, jul./dez. 2006 b. 
ROCHA, M. L. Educação em tempos de tédio: um desafio à micropolítica. Em: TANAMACHI, E.; PROENÇA, M.; e ROCHA, M. (Orgs.) Psicologia e educação: desafios teórico-práticos. São Paulo: Casa do Psicólogo, 2000. p. 185-207.

ROCHA, M. L.; UZIEL, A. P. Pesquisa-intervenção e novas análises no encontro da Psicologia com as instituições de formação. Em: CASTRO, L. R.; BESSET, V. L. (Orgs.) Pesquisa-intervenção na infância e juventude. Rio de Janeiro: FAPERJ/NAU, 2008. p. 532-556.

ROCHA, S. P. V. Tornar-se que se é: educação como formação, educação como transformação. Em: FEITOSA, C.; BARRENECHEA, M. A.; PINHEIRO, P. (Orgs.) Nietzsche e os gregos. Rio de Janeiro: DP\&A/Faperj/UNIRIO, 2006. p. 267-278.

RODRIGUES, H. B. C. Sejamos realistas, tentemos o impossível! - Desencaminhando a psicologia através da análise institucional. Em: JACÓ-VILELA, A. M.; PORTUGAL, F.T.; FERREIRA, A.A. (Orgs.) História da psicologia: rumos e percursos. Rio de Janeiro: Nau, 2005a. p. 515-564.

A psicologia social como especialidade: paradoxos do mundo psi. Psicologia \& sociedade, Porto Alegre, v. 17, n. 1, p. 83-88, jan./abr. 2005b.

ROLNIK, S. À sombra da cidadania: alteridade, homem da ética e reinvenção da democracia. Em: MAGALHÃES, M. C. R. (Org.) Na sombra da cidade. São Paulo: Escuta, 1995. p. 141170. 256,1993

Despedir-se do absoluto. Cadernos de Subjetividade, São Paulo, v.1, n.1, p. 244-

ROMANELLI, G. A entrevista antropológica: troca e alteridade. Em: ROMANELLI, G. \& BIASOLI-ALVES, Z. (Orgs.) Diálogos metodológicos sobre prática de pesquisa. Ribeirão Preto/SP: USP. Pós-graduação em Psicologia, 1998.

ROSSI, V. L. S. Desafio à escola pública: tomar em suas mãos seu próprio destino. Cadernos CEDES, Campinas, v. 21, n. 55, p. 92-107, nov. 2001. Disponível em <http://www.scielo.br/ pdf/ccedes/v21n55/5543.pdf>. Acesso em: 14 ago. 2008.

SAIDON, O. Introdução. Em: SAIDON, O.; KAMKHAGI, V. R. (Orgs.) Análise institucional no Brasil: favela, hospício, escola, FUNABEM. Rio de Janeiro: Espaço e tempo, 1987.

SAMPAIO, C. S. Ritmos de ensinar e aprender. Em: GARCIA, R. L.; SAMPAIO, C. S.; TAVARES, M. T. G. (Orgs.) Conversas sobre o lugar da escola. Rio de Janeiro: H.P. Comunicações/Profedições, 2006. p. 20-49. 
SANTOS, J. R. Processos socioculturais na Amazônia. Em: POSSIDÔNIO, R.; TADA, C. Amazônia: desafios e perspectivas para a missão. São Paulo: Paulinas, 2005. p. 109-132.

SATO, L.; SOUZA, M. P. R. Contribuindo para desvelar a complexidade do cotidiano através da pesquisa etnográfica em psicologia. Psicologia USP, São Paulo, vol. 12, n. 2, p. 29-47, 2001.

SEVCENKO, N. A corrida para o século 21. São Paulo: companhia das Letras, 2001.

SILVA, J. B. Unidades de conservação e organizações de populações tradicionais sulamapaenses: problemas, tendências e perspectivas. 2007. Tese (Doutorado em Desenvolvimento Sustentável no Trópico Úmido), Núcleo de Altos Estudos Amazônicos, Universidade Federal do Pará, Belém, 2007.

SOUZA, M. P. R.; MACHADO, A. M. As crianças excluídas da escola: um alerta para a psicologia. Em: Psicologia Escolar: em busca de novos rumos. São Paulo: Casa do psicólogo, 1997. p. 35-49.

SOUZA, M. Breve história da Amazônia. 2. ed. São Paulo: Marco Zero, 1994.

TACCA, M. C. V. R.; GONZÁLES REY, F. Produção de sentido subjetivo: as singularidades dos alunos no processo de aprender. Psicologia: Ciência e Profissão, Brasília, v. 28, n. 1, p. 136-161, mar. 2008.

TADEU, T. Tinha horror a tudo que apequenava. Revista Educação, São Paulo, v. 6, p. 6-15, 2007.

VEIGA-NETO, A. Quando a inclusão pode ser uma forma de exclusão. Em: MACHADO, A. M. et al. Psicologia e direitos humanos: educação inclusiva, direitos humanos na escola. São Paulo: Casa do Psicólogo; Brasília, DF: Conselho Federal de Psicologia, 2005. p. 55-70.

Cultura, culturas e educação. Revista Brasileira de Educação, n. 23, p. 5-15, maio/jun./jul./ago. 2003.

VELHO, O. G. Capitalismo autoritário e campesinato. São Paulo: Difel, 1976.

VIBISKI, V. N.; WEIRICH NETO, P. H. Casa familiar rural: uma escola diferente. Revista de Extensão Rural, Santa Maria, n. 11, p. 105-118, jan./dez. 2004.

WAGLEY, C. Uma comunidade amazônica: estudo do homem nos trópicos. Tradução de Clotilde da Silva Costa. 2. ed. São Paulo: Editora Nacional; Brasília: INI, 1977. 
WITKOSKI, A. C. Terras, florestas e águas de trabalho: Os camponeses amazônicos e as formas de uso de seus recursos naturais. Manaus: EDUA, 2007.

ZALUAR, A. Teoria e prática do trabalho de campo: alguns problemas. Em: CARDOSO, R. C. L. (Org.) A aventura antropológica: Teoria e pesquisa. Rio de Janeiro: Paz e terra, 2005. p. 107-125.

ZIBETTI, M. L. T. Os saberes docentes na prática de uma alfabetizadora: um estudo etnográfico. 2005. 252 p. Tese (Doutorado em Psicologia) - Instituto de Psicologia, Universidade de São Paulo, São Paulo, 2005.

ZORDAN, P. Criação de planos. Revista Educação, São Paulo, v. 2, n. 6, p. 38-47, 2007. 


\section{APÊNDICES}

\section{Vila Santa Rita}

(Carlito Ferraz e Luiz Antônio Ferraz)

Pelos amplos quartos

E assoalhos espelhados,

Escorreguei minha meninice.

As coisas pulsavam, então.

No pomar um cheiro de jasmim

Inundava o todo.

Entrava pelos beribás e pitangas,

E no cair da noite,

Alheios, os espíritos brincavam no pátio.

Dentro de casa, café de pilão,

Nuvens de tabaco no ar.

E eu no colo de vovó, mamãe grande,

Ouvindo cirandas do seu tempo de menina.

Emigrou, a família minguou.

Em nome do grande Amazonas,

Santa Rita ruiu, se acabou,

Em nome do Grande Amazonas. 